\title{
A MONOGRAPH OF THE LICHEN FAMILY MEGALOSPORACEAE
}

\author{
by \\ H.J.M. SIPMAN \\ with 24 plates
}


() 1983 A.R. Gantner Verlag K.G., FL-9490 Vaduz Printed in Germany

by Strauss \& Cramer GmbH, 6945 Hirschberg 2 ISBN 3-7682-1354-4 
Summary

The taxonomy of the family Megalosporaceae (Lecanorates, lichenised ascomycetes) has been revised basing on an examination of morphology, anatomy and chemistry of thallus and apothecia, and of apothecium ontogeny.

The Megalosporaceae are mainly characterised by features of the apothecium ontogeny, by thallus- and apothecium-chemistry, and by a range of spore types. Three genera have been distinguished within this family, Austroblastenia (gen. nov.) with two species, occuring in Australia and New Zealand, Megaloblastenia (gen. nov.) with two species, occuring in Australia, New Zealand and southern South America, and Megalospora, with twenty-five species, concentrated in Australasia, but with representatives throughout the tropical and warmtemperate zones of the world. The delimitation of these genera is based on spore structures. The species delimitations are mainly based on features of the epithecium pigmentation and granulation, spore structure and size, hymenium size and thallus chemistry. Species are defined as entities characterised by at least two independent differentiating characters. Entities with only a single such character (e.g. "chemospecies" or "secondary species") have been treated below specific rank or left unnamed.

The delimitation of the genus Megalospora has been changed. Several species had to be transferred to other genera, notably Catinaria, while on the other hand several Bombyliospora species, including its type, as well as a few species with muriform spores, have been included in Megalospora. In all 11 species and 3 subspecies are newly described.

Nearly all members of the family inhabit humid, cool forests, often cloud forest in tropical mountains. Basing on a cladistic analysis the ancestor of the family is supposed to have had bicellular spores with thick septa, which supports a relation with the Buelliinae. Most of the evolution of the family is supposed to have taken place on Gondwana-land, from which main migration routes have brought species into tropical Africa and America, into tropical and eastern Asia, and into southern South America. 


\section{Samenvatting}

Een revisie van de systematiek van de familie Megalosporaceae (Lecanorales, gelicheniseerde Ascomyceten) is het onderwerp van dit werk. Hiertoe zijn morfologie, anatomie en chemie van thallus en apotheciën, en de ontwikkeling van de apotheciën onderzocht. Als resultaat is het volgende systeem van de familie voorgeste1d:

De Megalosporaceae zijn vooral gekenmerkt door hun apothecium-ontwikkeling, door chemische stoffen in thallus en apothecia, en door een reeks spore-vormen. Er zijn drie genera onderscheiden: Austroblastenia (gen. nov,), met twee soorten die voorkomen in Australiazië, Megaloblastenia (gen. nov.) met twee soorten in Australazië en zuidelijk Zuid Amerika, en Megalospora met 25 soorten die over de hele wereld in tropische en warm-gematigde streken voorkomen, maar het meest geconcentreerd zijn in Australazië en Nieuw Guinea. De omgrenzing van de genera berust vooral op de bouw van de sporen, die van de soorten op het voorkomen van pigmenten en kristallijne stoffen in de apothecia, op bouw en afmetingen van de sporen, op de afmetingen van het hymenium en op de chemie van het thallus. Er zijn geen soorten geaccepteerd die slechts in éên eigenschap van andere afwijken, zoals "chemospecies" en "secondary species".

Tijdens het onderzoek bleek dat de vroegere omgrenzing van het genus Megalospora onhoudbaar was. Meerdere soorten zijn naar andere geslachten overgebracht, unl. naar Catinaria, en van de andere kant is het geslacht Megalospora uitgebreid met het grootste deel van het geslacht Bombyliospora, waaronder de typesoort, en met enkele nieuwe soorten met muriforme sporen. In totaal zijn 11 nieuwe soorten en 3 nieuwe ondersoorten onderscheiden.

De vertegenwoordigers van de Megalosporaceae komen vooral voor in vochtige, koele bossen, vaak in nevelbossen in tropisch gebergte. De familie is het nauwste verwant met de onder-orde Buelliinae, en een cladistische analyse maakt waarschijnlijk dat de voorouders van de familie tweecellige sporen met dikke septa gehad hebben. Het grootste deel van de evolutie lijkt plaatsgevonden te hebben in Gondwanaland, vanwaar drie hoofdroutes getraceerd kunnen worden, waarlangs soorten naar tropisch Afrika en Amerika, naar tropisch en Oost Azië en naar zuidelijk Zuid Amerika gemigreerd zijn, vermoedelijk vór het begin van het Tertiair. 


\section{Contents}

4. Morphology, anatomy, ontogeny and chemistry

A. Thallus morphology

B. Thallus anatomy

C. Apothecium morphology

D. Apothecium anatomy

E. Ontogeny and development of the apothecium

F. Morphology of ascus and spores

G. Development of asci and spores

H. Pycnidium

I. Chemistry

5. Discussion of the taxonomical conclusions

A. Delimitation of the family and the genera 60

B. Systematic position of the Megalosporaceae 66

C. Delimitation of species and infraspecific taxa 70

6. Keys

A. Key to the genera of crustose Leconorales with discoid ascocarps and $\begin{array}{ll}\text { large, bicellular spores } & 73\end{array}$

B. Key to the Catinaria species with large spores 73

C. Key to the Megalosporaceae $\quad 74$

7. Taxonomic treatment of the lichen family MegaZosporaceae $\quad 79$

Megalosporaceae Vezda ex Hafellner \& Bellemère 79

Austroblastenia gen. nov. $\quad 82$

1. Austroblastenia pauciseptata (Shirley) com. nov. 82

2. A. pupa spec. nov. 84 
Megaloblastenia gen. nov.

3. Megaloblastenia flavidoatra (Nyl.) comb. nov.

4. $M$.

marginiflexa (Hook. \& Tayl.) comb. nov.

var. marginiflexa

var. dimota (Malme) stat. nov.

Species with atrorubicans-type spores

5a. Megalospora atrombicons (Nyl.) A. Zahlbr.

ssp. atrorubicans

b.

ssp. australis ssp. nov. 97

ssp. sendaiensis (Räs.) comb. nov. 99

6. M. bartlettii spec. nov.

7a. M. gompholoma (Mü1l. Arg.) comb, nov. ssp. fuscolineata ssp. nov.

b.

ssp. gompholoma

8. $M$.

granulans spec. nov.

9. $M$.

hillii spec. nov.

10. $M$, sulphureorufa (Ny1.) Riddle

11. $M$. weberi spec. nov.

Species with sulphurata-type spores

12. $M$. campylospora (Stirton) comb. nov. 114

13. M. knightii spec, nov. 117

14. M. meZanodermia (Mü11. Arg.) A. Zahlbr. 120

15. M. subtuberculosa (Knight) stat. nov. 123

16. M. sutphurata Meyen var. sulphurata 125

var. nigricons (Mü11. Arg.) Riddle 131

Species with coccodes-type spores

17a. M.

b.

18. $M$.

19. $M$.

20a. M.

b.

c.

21. $M$. coccodes (Bé1.) comb, nov.

ssp. coccodes

ssp. nigricans (Mü11. Arg.) comb. nov. 
Species with tuberculosa-type spores

22. M. albescens spec. nov. 148

23. $M_{0}$ australiensis (Mü1l. Arg.) comb. nov. 150

24. $M_{\text {. }}$ halei spec. nov. 152

25. M. inflexa (Knight) comb. nov. 154

26. Megalospora tuberculosa (Fée) comb. nov. 156

Species with lopadioides-type spores

27. $M$. kalbii spec. nov. 164

28. M. Zopadioides spec. nov. 165

29. M. queenstandica spec. nov. 168

8. Excluded species and nomina dubia $\quad 170$

A. Species formerly included in Bombyliospora 170

B. Species provisionally referred to Catinaria 171

C. Lecania sulphureofusca 179

D. Mycobzastus 181

E. Various species formerly included in Megalospora 182

$\begin{array}{ll}\text { F. Nomina dubia } & 183\end{array}$

9. Notes on ecology, biology and conservation 184
A. Habitat ecology $\quad 184$
$\begin{array}{ll}\text { B. Life strategy } & 185\end{array}$
C. Dispersal capacity 186
$\begin{array}{ll}\text { D. Conservation } & 187\end{array}$

$\begin{array}{lr}\text { 10. Distribution patterns } & 189\end{array}$

11. Reconstruction of the evolutionary history 196

A. Estimation of the phylogenetic relationships 196

B. Chronological and geographical aspects 205

$\begin{array}{lr}\text { References } & 212\end{array}$

$\begin{array}{ll}\text { Index of names in taxonomical treatment } & 219\end{array}$

$\begin{array}{ll}\text { Index of examined specimens } & 224\end{array}$

$\begin{array}{lr}\text { Acknowledgement } & 241\end{array}$ 
Plates 


\section{chapter 1. INTRODUCTION}

One of the striking features of the classical system of the lichens by ZAHLBRUCKNER (1926) is the nearly mathematical arrangement, based on the spore size and septation, of the genera in the family Lecideaceae. Probably the most peculiar among these genera is Megalospora, characterised by the presence of large, bicellular spores. It is conspicuous both by the large dimensions of the spores and by the unusual fact that they are bicellular, not muriform as would be likely in view of the usual size of spore cells, nor simple as in the majority of the large-spored lichens, e.g. in the genus Pertusaria. Another intrigueing aspect of Megalospora is the relation with the genera Mycoblastus and Bombyliospora, which fit in the same mathematical arrangement and are characterised by large, uniceliular, viz. bacillar-pluricellular spores. The three were originally considered to be related (cf. MASSALONGO 1860), but Bombyliospora was placed by ZAHLBRUCKNER in the family Teloschistaceae.

Thus many questions can be raised about this genus Megalospora. Does the 'mathematical' arrangement of the genera in the Lecideaceae reflect the natural relationships? And if so, should Megalospora be considered to be a large-spored derivative of the genera Catillaria or Catinaria or rather a relative of Mycoblastus and Bombyliospora with bicellular spores? Or should Megalospora, perhaps together with Bombyliospora, which resembles it closely in external appearence, be taken out of the Lecideaceae, and should it, like Bombyliospora, better be placed in the Teloschistaceae?

To answer these questions an investigation of all species attributed to MegaZospora seemed advisable, to detect whether they constitute a homogenous group, and whether this possesses characteristic features other than the large, bicellular spores, which may indicate the true relationships of Megalospora and the higher taxonomic categories to which it belongs.

At species level the need for such a revision was also clear, because no world-wide treatment has ever been presented. Lack of sufficient collections must have been preventive, because many species occur in poorly investigated, tropical areas. In fact only incidental collections were available until the last decades from important areas such as New Caledonia, New Guinea and Sabah. World-wide studies are required for an understanding of the range of variation of the species, and to clear confusions like the misapplication of names in different geographical areas. 
The present study became opportune by the availability of much recent collections and the establishment of new character groups. Among these should be mentioned the occurrence of secondary metabolites and the ontogeny of the ascocarps. Also the recent change in appreciation of the apothecium anatomy, of the anatomy and development of the spores as well as of the shape and structure of the ascus made a reevaluation of the genus Megalospora of interest. Among the collections that became available during the last decades a special mention deserve those of J. Bartlett (New Zealand), M. E. Hale (Sabah, Philippines), D. J. Hil1 (New Caledonia), J. Lambinon (tropical Africa) and W. A. Weber (New Guinea) 


\section{chapter 2. HISTORY}

The first species of Megalosporaceae described is Megalospora tuberculosa, which was described by FEE (1824) as Lecidea tuberculosa in his work on the cryptogams of the medicinal barks. Following the system of ACHARIUS (1803) the species was placed in the genus Lecidea, which was defined by the crustose or squamulose thallus and discoid apothecia with concolorous margins. The original description of Megalospora tuberculosa did not contain information about the spores, as usual at that time. These were described in a supplement (FEE 1837).

SPRENGEL (1827) transferred the species to the genus Patellaria, which was defined in a sense very different from nowadays, including many lichenised ascomycetes, among which the genus Lecidea sensu ACHARIUS. This system was followed by DELISE (1830) when describing Patellaria pachycarpa (a synonym of Megalospora tuberculosa).

FRIES (1831) modified ACHARIUS' system by separating the genera Lecidea and Biatora, based on the presence of a lecideine or a biatorine margin. The artificiality of this division is demonstrated by the fact that Patelzaria pachycarpa was transferred in his work to both Lecidea and Biatora.

The genus Megalospora was described in 1843 by MEYEN \& FLOTOW, with a single species, M. sulphurata. Their description was large1y based on the apothecium structure and the data on the spores were inaccurate, as was pointed out by MUELLER ARG. (1883). FLOTOW (1850) later changed the name of the genus into Heterothecium because "Ihr Character liegt nicht in den grossen Sporen". It is remarkable that he included Lecidea tuberculosa in this genus, thus approaching the roncept of the genus Megalospora as used in the present paper.

Other Megalosporaceae described in the $1840^{\prime} \mathrm{s}$ were placed in Lecidea or Biatora following the system of FRIES, e.g. Lecidea marginiflexa (HOOKER \& TAYLOR 1847) and Biatora porphyritis (TUCKERMAN 1848). Exceptions are Lecanora vigiZans (TAYLOR 1847), which was probably placed in another genus because of a misinterpretation of the apothecium margin, and Parmelia coccodes (BELANGER \& BORY de SAINT VINCENT 1846), in which case unfamilarity of the author with 1ichens has probably lead to confusion of genera. Already in 1848 the latter species was transferred by MONTAGNE to Biatora.

Around the middle of the last century new classifications of the lichens were proposed, notably by MASSALONGO $(1852,1860)$. He divided the Acharian genus Lecidea 0.a. in two parallel series of genera with unicellular, bicellular and bacillar-pluricellular spores, viz, a small-spored series composed of 
Lecidea s. str., Catillamia and Bacidia, and a large-spored series, composed of Megalospora, Psorothecizon and Bombyliospora. In his system the genus Megalospora was emended to include species which are currently placed in Mycoblastus. This classification has been followed by e.g. KOERBER (1855) and in this way the name Megalospora came into use for European 1ichens in the last century. Psorothecium was introduced for the group with the same delimitation as Megalospora sensu ZAHLBRUCKNER and the genus Heterothecizm was emended in such a way that it included only species with muriform spores. NYLANDER considered MASSALONGO's subdivision of Lecidea artificial and continued to use Lecidea in a wide sense, including the Megalosporaceae. In the meantime TREVISAN (1853) had placed some Megalosporaceae in Bacidia, e.g. B. coccodes, B. pachycarpa and B. tuberculosa.

Most authors in the second half of the last century dealing with exotic 1ichens followed MLANDER, and described new Megalosporaceae in the genus Lecidea, a.o. FEE, KNIGHT, LEIGHTON, SHIRLEY and STIRTON. VAINIO even continued to do so until 1921. Descriptions of Megalosporaceae in other genera are usually based on inaccurate observation of the apothecium margin or the spores, e.g. Lecania ananplificans (MUELLER ARG. 1882), Lecanora versicolor var. vigilans (NYLANDER 1869), Lecanora amplificane (NYLANDER 1867) and Blastenia taitensis (TREVISAN 1856). TUCKERMAN $(1872,1888)$ reintroduced the genus name Heterothecium. STEIN (1883) described a new, monotypic genus for Megalospora maderensis, viz. Dumoulinia, which has never been used afterwards.

In the last decades of the last century the work of MUELLER ARG. has been of considerable importance. Unfortunately he reintroduced the genus name Patellaria in a wide sense for lichenised ascomycetes, thus necessitating a lot of recombinations. Also the Megalosporaceae were included in his concept of this genus, which has not been accepted by many other lichenologists. A single Megaloblastenia species was placed by him in Blastenia, as B. endochromoides (1894).

By the end of the nineteenth century the wide concept of the genus Lecidea found resistance again, and Megalosporaceae species were placed in various revived genera: Biatorina( B. subvigilans, HELLBOM 1896), Catillaria (C. sulphura$t a$, VAINIO 1912b), Psorothecium ( $P$. schadenbergianum, STEIN 1888). ZAHLBRUCKNER (1907, 1926) brought stabilisation again, by reintroducing part of MASSALONGO's system, with corrected names. The genus Lecidea s.1. fell apart in many subdivisions, most of them placed in the family Lecideaceae and artificially based on spore septation. The name Megalospora was adopted for the species with large, bicellular spores. The group with large, bacillar-pluriseptate spores, for 
which the name Bomby Ziospora was adopted, was placed by ZAHLBRUCKNER at first (1907) in the Lecideaceae, but later (1926) in the family Teloschistaceae, because of the presence of thick spore septa in some species. This family Teloschistaceae included also part of Megaloblastenia, as Blastenia. ZAHLBRUCKNER's sytem was followed by e.g. RIDDLE $(1912,1917)$ and became more or less generally accepted, especially after the appearence of the Catalogus Lichenum Universalis (ZAHLBRUCKNER 1927 a.o.).

In recent years weaknesses in ZAHLBRUCKNER's system became apparent. SANTESSON (1952) removed a foliicolous species from Megalospora: Psorotheciopsis premeella. VEZDA (1974) suggested to unite Megalospora and Bombyliospora with a few other lichen genera in a separate family Megalosporaceae (cf. p. 65). HAFELLNER \& BELLEMERE (1982) considered the ascus structure a good character of such a family, and HAFELLNER \& BELLEMERE (1982b) removed the Bomby Ziospora species with thick spore septa and anthraquinones from this genus and placed them in a separate genus Letrouitia.

No revision of the genus Megalospora on a world-wide scale has ever been undertaken. An attempt to a revision by RIDDLE (1917) unfortunately concentrated on America, where the genus appears to be poorly represented. A fairly large series of species is dealt with by workers on the lichen flora of New Zealand, e.8. NYLANDER (1888), MUELLER ARG. (1894), HELLBOM (1896). However, they have mostly copied eachother, and the most valuable contributions to the knowledge of the New Zealand species has been made by KNIGHT $(1875,1883)$. Otherwise the activities concerning Megalosporaceae were largely restricted to isolated descriptions of new species. 
chapter 3. MATERIAL AND METHODS

The present study is based on an examination of about 1,000 specimens of Megalospora as defined by ZAHLBRUCKNER (1927) as well as about 200 specimens with spores of the type characteristic of Bombyliospora or Lopadizm. These specimens were obtained by loan from the following herbaria: BM, BR, CHR, COL, COLO, FH, FI, G, H, HO, L, LG, LSU, M, MB, MERF, NSW, PC, S, TNS, TUR, U, UPS, US, W, WELT, WRSL and the private herbaria of Bartlett (Pakuranga), Kalb (Neumarkt),

Poelt (Graz) and Tucker (Baton Rouge). Additional collections have been made by the author in Costa Rica, Venezuela, Colombia, Brasil, Papua New Guinea, Australia and New Zealand, and are preserved in $U$.

For Megalospora sensu ZAHLBRUCKNER all material of the following herbaria has been borrowed in order to obtain a good representation of specimens on a worldwide basis: BM, BR, COL, COLO, FH, G, H, L, LSU, M, MERF, NSW, S, U and US. From other herbaria selected specimens, of ten only type specimens, have been examined. For the groups with Bombyliospora- or Lopadium-type spores a large amount of material has been examined from the herbaria CHR, COLO, G, H, L, MERF, NSW, W and US. Otherwise the study has been restricted to selected specimens and types. Material for comparison from related genera has been obtained from $U$.

For the examination of the specimens the following techniques have been used: 1. macroscopical examination by low-magnification stereomicroscope at 7-40 $\mathrm{x}$.

2. microscopical examination of hand-made sections of apothecia, thallus fragments and pycnidia at 40-1000 $\mathrm{x}$, and of soredia.

3. microscopical examination of sections made with a freezing microtome, at 40-1000 x.

4. scanning electron microscopy (SEM) of thallus fragments with apothecia.

5. thinlayer chromatography (TLC) of extracts of apothecia and occasionally also of the thallus.

ad 1. This has been used in all specimens for observation of the thallus surface, the dimensions of isidia or soralia, apothecial morphology, dimensions and colour, and the colour of the apothecial tissues in sections. Thallus colour has been examined with the naked eye in daylight. All observations are on air-dried specimens.

ad 2. This has been done in all cited specimens. The following working scheme has been adopted for examination of the apothecial anatomy and spore morphology: a. selection of a fully-grown but not large apothecium, c. $1.5 \mathrm{~mm}$ wide, from suf- 
ficiently well-developed specimens. A whole apothecium has been used for the sectioning in order to have more chance to find we11-developed spores, which are often scarce, and to obtain enough secondary metabolites for TLC (cf. step f). When the material was unsufficient to allow the use of a whole apothecium (and especially in type specimens) one or two sections have been cut from an apothecium in situ under the stereomicroscope. Preferably an already cut apothecium was chosen for this, because such an apothecium might have been used for earlier descriptions. These sections were treated following steps $d$ and further. b. soaking of the apothecium in ethanol (c. 90\%), to expell the air, and afterwards in tap water.

c. preparation of hand sections with the aid of razor blade and Sambucus pith. These hand sections, about 50-200 $\mu \mathrm{m}$ thick, have the advantage that the large asci with spores remain intact.

d. microscopical examination in water mounts of spore form and dimensions, hymenium inspersion and dimension, epithecium colour and granulations. The excipulum colour has been observed under a stereomicroscope with incumbent light. e. observation of colour reactions with $I$ - and $\mathrm{K}$-solutions (DUNCAN 1970, P. XLII and XLI) on selected sections under the microscope.

f. washing away of the secondary metabolites from the remaining sections after air-drying, by adding and evaporating drops of acetone at room temperature, following the second method described by THOMSON (1967, p. 16). The extracted secondary metabolites have been used for TLC.

B. resoaking of the sections in ethanol (c. 90\%) and afterwards in tap water. h. transport of the sections into lactophenol cotton-blue solution (DUNCAN 1970, p. XLIII) for the preparation of semipermanent mounts.

i. microscopical examination of these semipermanent mounts after one day for additional measurements of apothecium height and base width, and for observation of the hyphal structures, presence of crystals of calcium oxalate, and change in oil droplets or granules.

For special study of the asci, sections have been soaked in K-solution and afterwards stained with I-solution. The asci have been separated from the paraphyses by gentle pressing with the points of a pair of forceps under the microscope wi th low magnification.

The dimensions of the soredia have also been measured under the microscope, at low magnification, with incumbent light and in air-dried state. ad 3. This has been used mainly for study of the ontogeny of the ascocarps. For this investigation a few specimens were selected, cited in chapter 4, 
of which thallus fragments of c. $2 \mathrm{~mm}^{2}$ have been taken with supposed primordia, recognisable as darker, slightly raised spots on the surface. The fragments have been soaked in ethanol $(90 \%)$ and afterwards in tap water. Then they have been mounted on a freezing microtome for exact orientation. Sections have been cut at a temperature of minus $20^{\circ} \mathrm{C}$ and at a thickness of 18-21 $\mathrm{mm}$. They have been treated as indicated under point 2 , step $f$ and further, to make semipermanent cottonblue-stained mounts. These have been examined for observation of the structures formed by the hyphae and algae.

ad 4. SEM-observations have been done only on a few fragments of Catinaria versicolor, Megalospora atrombicans and $M$. sulphurata. These have been air-dried, mounted and gold-coated, as described by HALE (1973, p. 2), and observed at magnifications of 100-500 x, occasionally $1000 \mathrm{x}$.

ad 5. TLC has been performed in order to identify the secondary metabolites which are present in high quantities, following the procedure developed by CULBERSON \& KRISTINSON (1970) with later modifications (WALKER \& JAMES 1980), on Merck's precoated plates (Kieselgel 60F-254). Extracts have been made by the second procedure described by THOMSON (1967, p. 16) at room temperature. Only solvent system A has been used. The developed plates have been observed under short-wave (254 \&) and long-wave ( $350 \AA)$ UV-light, and sprayed with tap water to detect fatty acids. For confirmation of the substance identifications the chromatograms have been compared with those of lichens with known substances. The relation between the detected substances and the K-reaction of the apothecium sections has been established by occasional colour tests on the TLC spots.

The nature of the crystals of calcium oxalate has been proved in a few cases by their solubility in concentrated acetic acid and/or diluted hydrochloric acid. In the first they do not dissolve, in the second they do without effervescence. Experiments to remove the crystals before sectioning, to obtain better sections, have been unsuccesful.

The secondary metabolites in the apothecium have been investigated in most specimens, in at least ten specimens of each species if possible. The chemistry of the thallus has been studied only incidentally because the substances present in the thallus appeared to be present equally in the apothecium. 


\section{chapter 4. MORPHOLOGY, ANATOMY, ONTOGENY AND CHEMISTRY}

In this chapter descriptions are given of morphology, anatomy, ontogeny and chemistry of the Megalosporaceae. Data from Catinaria versicolor and Leconia sulphureofusca have been included to make clear the differences with these species, which were previously considered to be close relatives of the Megalosporaceae. In the section on apothecium anatomy moreover a series of 19 species of Leconorales have been treated, to obtain an impression to what extent the struct. ures in the Megalosporaceae are comparable with those in other Leconorales.

\section{A. Thallus morphology}

The surface of the thallus may be completely smooth and following the surface of the substrate. In case this is rough bark or bryophytes, the thallus may assume a very irregular shape, and even look isidiose or subfruticose. In most specimens the surface of the thallus is uneven of itself, showing raised parts of c. 0.1-0.2 mm in diameter, surrounded by depressions(Pl, 2 C, D). This appearance is referred to as "rugulose" in the descriptions below. Probably it is caused by the increased growth rate of localised areas in the thallus. It is most well developed in humid situations. Then in many species the raised parts.may develop into warts which are $0.2-0.5 \mathrm{~mm}$ wide and $0.2 \mathrm{~mm}$ high. Thallus cracking occurs in species with a thick thallus. It is of a rimose nature (P1. I A, D).

Sometimes the thallus shows a free lower side, which is brown and suggests a lower cortex. However, clinging substrate remnants indicate that this feature is caused by disappearance of the substrate, which in many specimens consists of soft bark in a process of rapid humification.

Isidia or soredia are present in a number of Megalosporaceae, of ten as inconstant features. Isidia have been found in e.g. Megalospora bartlettii, M. halei and $M$. sulphurata (P1. 1 C, 2 B), soredia in e.g. Megaloblastenia marginiflexa var. marginiflexa, Megalospora gronulans, M. subtuberculosa, M. sulphurata and $M$. tuberculosa (P1, 2 A). The isidia consist of cylindrical or coralloid structures of c. $0.2 \mathrm{~mm}$ thick and $1 \mathrm{~mm}$ long (P1. $3 \mathrm{D})$. Soralia develop from the raised parts of the thallus, which burst open and produce soredia. In some species the soralia coalesce, forming large sorediate patches, e.g. in M. granulons.

In e.g. Megalospora coccodes and $M$. tuberculosa larger wart-like structures may be present, here called tubercles. These are c. $0.5 \mathrm{~mm}$ wide and of about the same height. 
With scanning electron-microscopy the surface of the thallus appears to be usually rather smooth and like covered with mucilage, with a few hyphae visible on the surface (P1, 3), Sometimes the surface is porous (P1, $3 \mathrm{C}$ ).

\section{B. Thallus anatomy}

All investigated specimens have a crustose thallus in which three layers can be distinguished: a cortical layer, an algal layer and a medullary layer (P1. 4),

Two types of cortical arrangement have been found. In all Megalosporaceae and in Lecania sulphureofusca (P1. $4 \mathrm{~A}-\mathrm{C}, \mathrm{F}$ ) it is about $10 \mathrm{\mu m}$ thick and almost entirely necrotic. In the outer part no hyphal structure is visible, in the internal part the hyphae are more or 1 ess periclinally arranged and conglutinated but not thick-walled. Alternatively in Catinamia versicolor (P1. 4 D) the cortical layer is about $20 \mathrm{~mm}$ thick and composed of slightly swollen, thick-walled, conglutinated hyphae which are irregularly or somewhat periclinally arranged. Usually the upper part is necrotic.

The remaining parts of the thallus are arachnoid, composed of irregularly orientated, loosely wefted hyphae. The algae are concentrated in a c. $100 \mathrm{~mm}$ thick layer immediately below the cortex (algal layer). In deeper layers, over c. $100 \mu \mathrm{m}$ below the surface, only hyphae are present (medullary layer). The 10wer parts of the thallus may include bark cells. At the edge of the thallus the hyphae may be enveloped in a brown-black substance, and thus form a black prothallus (P1. 4 E). Similar hyphae have also been observed below the medulla. The secondary metabolites can be seen as clusters of crystals on and among the hyphae of fresh sections. In old herbarium specimens the thallus may become covered in very fine, bluish needles, giving the specimens the appearance of being overgrown by fungal hyphae.

A frequent feature is the occurrence of overlapping cortical layers in the thallus, separated by interstitial arachnoid layers (P1. 4 F). Probably this feature is caused by the regeneration of previously moribund parts of the thallus.

The phycobiont of the Megalosporaceae and the investigated Catinaria- and Lecania species seems to belong to the genus Dictyochloropsis. The same species was present in cultures from specimens of Megalospora atrombicans ssp. austraZis. M. gompholoma ssp.gomphozoma and Catinaria grossa from New Zealand (personal communication by $E$. Tschermak-Woess). 


\section{Apothecium morphology}

The adult apothecia of all investigated specimens are sessile, with the lower side resting on and fused to the upper surface of the thallus, cf. P1, 1 and 2 . The margin is usually thick and prominent glossy or dul1, and sometimes pruinose. In young apothecia the disc is markedly concave with prominent margins, or nearly flat. In old apothecia the disc may become convex and the margin inapparent. In wet apothecia the disc is raised and the margin less prominent. The colour of the disc varies from pale reddish brown to black. Like the margin, it may be glossy or dull, and sometimes pruinose (P1. $1 \mathrm{~B})$. The pruina is usually white, but its colour is difficult to estimate due to the underlying colour of the disc. Occasionally taxonomic value is found in a weak development of the margin (P1. $1 \mathrm{D}$ ) or a conical shape of the apothecium (P1. $1 \mathrm{~A}$ ).

Measurements of the adult size in the species accounts are taken from larger apothecia with still flat disc. For the juvenile size apothecia have been measured in which the disc is twice as wide as the margin. So this size reflects mainly the thickness of the margin. The thickness of the apothecium has been measured from mounted sections. Because the thickness increases slightly with age, measurements have been taken from sections of comparable, young apothecia.

\section{Apothecium anatomy}

The apothecial anatomy of the Megalosporaceae offers several structures for which use of the existing terminology may lead to confusion. Therefore in this section narrow definitions for some terms are given, and detailed descriptions are included of the corresponding structures in the Megalosporaceae.

To avoid misinterpretation of the terms by over-emphasis of the specialities of the Megalosporaceae, apothecia of the following species have also been investigated: Bacidia muscomon (Ach.) Mudd, leg. Pos 71.1456 (U), B. obscurata (Sommerf.) Zahlbr., leg. Daniëls \& Sipman DS-161 (U), Brigantiaea fuscolutea (Dicks.) R. Sant., leg. Kristinsson 11417 (U), Caloplaca cerina (Ehrh. ex Hedw.) Th. Fr., leg. Stud. Biol. 73-447 (U), C. ferruginea (Huds.) Th. Fr., 1eg. Stud. Biol. 69590 (U), C. quadrilocularis (Nyl.) Zahlbr., leg. Sipman 13075 (U), Catinaria grossa (Pers. ex Ny1.) Vainio, leg. Salm 957 (BM), Cliostomum griffithii (Sm.) Coppins, leg. Henssen $17483 \mathrm{f}$ (MB), Huilia macrocarpa (DC) Herte1, leg. Stud, Biol. 69-470 (U), Lecanora atra (Huds.) Ach., 1eg. Tucker 20373 (LSU), L. subfuscata Magn., leg. Pos 72.685 (U), Lecidea caesioatra Schaer., leg. Stud. Biol. 75-751 (U), Lecidella elaeochroma (Ach.) Choisy, leg. Heemstra et. al. 699 (U), Letrouitia domingensis (Pers.) Haf. \& Bellem., leg. Sipman 12314 (U), Lopadium 
pezizoideum (Ach.) Körb., leg. Stud. Biol, 75-664 (U), Micarea prasina Fr., leg. Anon., ZW. L. 593a (MB), Mycoblastus sanguinarius (L.) Norm., leg. Stud. Biol. 72-8.n. (U), Parmelia acetabulion (Neck.) Duby, leg. Stud. Biol. 74-269 (U), Placopsis parellina (Nyl.) Lamb, leg. Sipman 10420 (U), Rinodina miaraea (Ach.) Körb, leg. Stud. Biol. 75-554 (U).

For the terminology for the apothecial anatomy in general HERTEL's (1967, p. 4, 5, Taf. 1) terminology for Lecideaceae has been followed. Some additions have been taken from ANDERSON (1964, p. 9). In the descriptions of the structures the first part treats the general situation, based on observations of the specimens mentioned in the preceding paragraph. After that the specialities of the Megalosporaceae are treated. A schema of the structures is given in fig. 1.

1. EPITHECIUM. This is taken in the usual sense for the differentiated uppermost layer of the hymenium: its differentiation may be caused by swelling or increased branching of the paraphyses, by deposition of pigments, crystals or other substances, or by a combination of these factors. It is equivalent to the epihymenium of e.g. HERTEL (1967).

In Megalosporaceae the epithecium is marked by a diffuse brownish or blackish pigment which occurs in a c. 10-20 $\mu$ thick layer. The tips of the paraphyses are hardly thickened, but more frequently branched (P1. 6 A). Usually they do not extend above the gelatinous matrix of the hymenium, as in Catinaria versicoLor (P1. 9 F). Sometimes the surface layer is granular, the granules appearing yellow under the microscope.

2. HYMENIUM. This layer consists of the asci and the paraphyses, usually imbedded in a gelatinous or cartilagineous matrix. On the upper side it is not sharp1y delimited from the apothecium because the features which characterise the epithecium, do not all extend over the same zone. E.g. a diffúse pigment may extend further down than apical branchings or swellings of the paraphyses, while a granular pigment is often limited to a zone around the tips of the paraphyses or even to a layer above the tips (epipsamma). Therefore in measurements of the height of the hymenium the epithecium is included.

On the lower side the hymenium is delimited by the level of the bases of the ripe asci. In many species, e.g. Catinamia versicolor, this level changes stadily because the new asci are not developed on the same level as the older ones (P1, 9 C). Thus when measuring the thickness of the hymenium care should be taken to look for well developed asci, and to avoid those which are young or degenerating. Thus defined, the height of the hymenium is a good indication of the ascus length, because in the observed Leconorales the asci extend to a fixed 


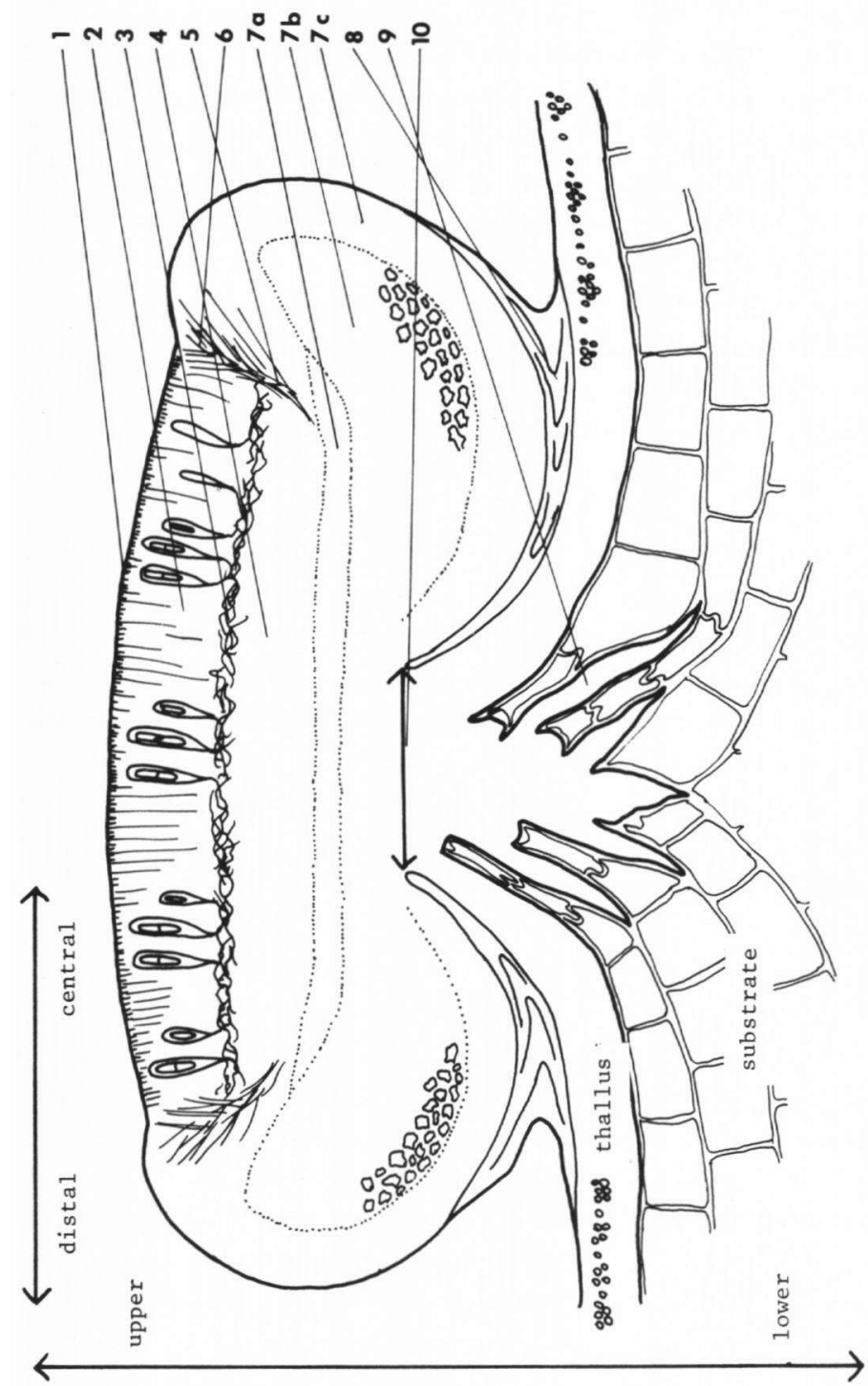

䙷息

自沀

造

苛总

步安

空慁

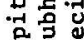

a in

- 亦

字酋으

可

궁

장

s.

을

\&

잉

उ.

8 .

\&

.

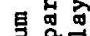

。

章.

응

造密

岁哭

. 的悬

通家

- 立

눰

包

$\overbrace{i=1}^{\infty} \dot{i}$ 
distance of about 10-20 $\mathrm{mm}$ below the surface of the disc. Probably this distance is determined by the length of the rostrum which is formed at the dehiscence of the asci (LETROUIT-GALINOU 1973, p. 35).

In the Megalosporaceae a common feature is the presence of droplet-1ike bodies in the hymenium (P1. 5 D), further referred to as oil droplets, though their true nature is unknown. They are hyaline and rounded or elongate with rounded edges, appearing like melting crystals. Their size ranges usually between 1 and $4 \mu \mathrm{m}$ in width, but sometimes larger droplets of $10 \mathrm{\mu m}$ width have been observed. They are only present in fresh sections in water mounts, and disappear in e.g. cotton-blue stained mounts.

The ascus type in the Megalosporaceae is discussed on p. 44. The paraphyses show little variation. They are thin, c. 1 m thick, hardly thicker at the api-

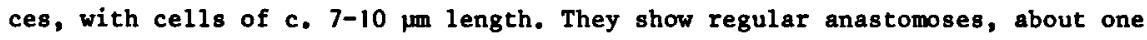
for each paraphysis, and often one or a few bifurcations at the apex (P1. 5 B, $6 \mathrm{~A}, 8 \mathrm{D})$.

The staining of the hymenium with I-solution is very variable. In Megaloblastenia the whole hymenium assumes a blue colour, in other Megalosporaceae the hymenium stains at most partly. The parts that may turn blue, are the basal zone of the hymenium, the asci (often only the tips), and a thin zone surrounding the ascus tips. However, in specimens where the asci are numerous and become intensily stained, the whole hymenium may appear to turn blue. The hymenium may also assume a yellowish to reddish tinge upon application of I-solution, in various degrees, and often strongest in the ascus contents. Superimposition of both colours may give a blackish hue to the treated ascus tips or a purplish hue to the asci.

The height of the hymenium is sometimes diagnostic in the MegaLosporaceae, but in general it is very variable. This variability depends in part on the age of the apothecium, as was found also in other lichen groups, e.g. in Pyxine (SWINSCOW \& KROG 1975). To avoid this source of variation in the hymenium height nearly always young apothecia of comparable age have been examined for the present study. Exceptionally high hymenia have been measured when only large, old apothecia were available, e.g. 260-300 $\mathrm{m}$ in Megaloopora coccodes ssp. coccodes from Colombia.

3. SUBHYMENIUM. This term has been used in different senses and confused with the hypothecium (HENSSEN \& JAHNS 1973, p. 91). In the present study it is restricted to the layer which contains the functional ascogenous hyphae, recognisable as thick hyphae staining intensily with cotton blue. The upper limit has 
been laid on the level of the bases of the adult, not yet degenerating asci, adjacent to the lower limit of the hymenium. This delimitation is necessary to cover also lichens where the young asci are developed on a raising level and the ascogenous hyphae penetrate into the hymenium, e.g. Catinaria versicolor (P1. $9 \mathrm{c})$. The lower limit of the subhymenium is defined here as the level where the ascogenous hyphae desintegrate.

4. HYPOTHECIUM. This term has been used here in the sense of HERTEL (1967, Taf.

1) for a layer containing remains of asci and/or the ascogenous apparatus (cf. ANDERSON 1964, p. 10). The paraphyses can sometimes be traced down into the hypothecium, where they loose their parallel orientation, e.g. in the Megálosporaceae and in Catinaria versicolor (P1. $5 \mathrm{~B}, 9 \mathrm{C}$ ).

Thus defined the hypothecium agrees with the "Bildungsschicht" of HENSSEN \& JAHNS (1973, p. 91) and also more or less with the medulla as described by BELLEMERE (1967) in non-1ichenised ascomycetes. Contrary to HERTEL (1967), HENSSEN \& JAHNS (1973, p. 91) use the term hypothecium for the layer with ascogenous hyphae. For the hypothecium together with the subhymenium they use the term "subhymeniale Schichten" (subhymenial layers).

By the definition given above, the upper limit of the hypothecium borders the subhymenium. The lower limit is the contact with the subhypothecium and the parathecium. This limit is often unclear, especially when the parathecium is not very clearly developed.

In Catinaria versicolor degenerating spores and hollows can be observed in the hypothecium. Such a feature is described also by HENSSEN for Buellia (1968, p. 7, P1. III, $i$ and V, f). This suggests that a resoption of old hymenium tissue takes place within the hymenium of these species. In the Megalosporaceae the hypothecium forms a usually clear layer of variable thickness. Assuming that it has also in Megalosporaceae a resorbing function, the thickness might depend on an equilibrium between growth of the hymenium and resorption in the hypothecium. In many of the investigated Lecanorales, where the ascogenous hyphae remain clear far down, a hypothecium can hardly be distinguished from the subhypothecium, e.g. in Caloplaca cerina, Cliostomm griffithii, Lecidella elaeochroma, Letrouitia domingensis, Rinodina miaraea and also in Megaloblastenia marginiflexa.

5. PARATHECIUM. This term is used here in a restricted sense for a compact layer of radiating hyphae below the hypothecium. It agrees with the medulla as defined by MOSER-ROHRHOFER (1960), not in the sense of BELLEMERE (1967), where it is comparable with the hypothecium (4). 
The parathecium is distinct in species with lecanorine apothecia, such as Caloplaca cerina, Lecanora subfuscata, Lecania sulphureofusca (P1. 8 E) and Rinodina miaraea (P1. $10 \mathrm{~A}$ ), where it forms a layer of parallel hyphae between the more or less conical hypothecium and the thalloid amphithecium (p. 27). It is composed of thick-walled, more or less conglutinated hyphae and is apparently a persistent structure in these species. Often it is referred to as the "proper margin". In Megalosporaceae and many other lichens with biatorine or lecideine apothecia, such as Bacidia muscomm, B. obscurata, Brigantiaea fuscolutea, Catinaria grossa, C. versioolor, Cliostomon griffithii (P1. 11 A), Huilia macrocar $\mathrm{pa}_{1}$ Lecidea caesioatra, Lecidelza eZaeochroma, Letrouitia domingensis (P1. 11 c), Lopadium pezizoideum, Micaria prasina and Mycoblastus sanguinarius, the parathecium is very weakly developed and reduced to a ring on the outer margin of the subhypothecium (7a) or lacking altogether (PI. 9 B). In these species it is composed of thin-walled, apparently undifferentiated hyphae, and is apparently not persistent but follows the margin of the subhypothecium during the growth of the apothecium.

Distally the parathecium passes gradually into the parathecial crown (6). In Lecania sutphureofusca and other lecanorine species it is interrupted centrally, where it indicates the apothecium basis (10) (P1. 8 B). In biatorine and lecideine apothecia the central parts are equally absent, and it is unclear whether it is resorbed here, or integrated in the subhypothecium. The latter possibility is supported by BELLEMERE (1967, p. 903), who suggests that the parathecium may give rise to the podium, a structure comparable to the subhypothecium as used here (cf, p. 28).

6. PARATHECIAL CROWN. Following LETROUIT-GALINOU (1966, 1969) the system of undifferentiated hyphae which divaricate from the distal margin of the parathecium, is called here parathecial crown. Towards the hymenium the hyphae of the crown differentiate into paraphyses, towards the excipulum into excipular hyphae.

In Caloplaca cerina (P1. $10 \mathrm{C}$ ), Leconora subfuscata, Leconia sulphureofusca (P1. $8 \mathrm{E}$ ) and Rinodina miaraea (P1. $10 \mathrm{~A}$ ) the parathecial crown is very distinct as a widened part on top of the parathecium. In Megalosporaceae (P1. 5 C, $8 \mathrm{E})$ and other lecideine and biatorine lichens such as Bacidia muscomm, Brigantiaea fuscolutea, Catinaria grossa, C. versicolor (P1. 9 B), Cliostomm griffithii (P1. 11 A), Huilia macrocarpa, Lecidea caesioatra, Lecidella elaeochroma, Letrouitia domingensis, Lopadium pezizoideum, Micarea prasina and Mycoblastus sanauinarius. it is less distinct.

7. EXCIPULUM. This term is used here for the entire supporting structure of the 
apothecia as far as it originates from the primary corpus. In Megalosporaceae three parts can easily be distinguished (cf. P1. 5 A): subhypothecium (7a), medullary excipulum (7b) and ectal excipulum (7c). This differentiation is applicable because the medullary excipulum is clearly distinct from the other parts by its arachnoid structure. In 1 ichens without such an arachnoid layer in the excipulum, e.g. Bacidia muscomum, B. obscurata, Cliostomum griffithii (P1. 11 A), Lecidea caesioatra, Lecidella elaeochroma, Lopadium pezizoideum, Micarea prasina and Mycoblastus sanguinarius, such a division of the excipulum is not applicable. According to ANDERSON (1964, p. 9) the medullary excipulum is then considered to be absent.

In the terminology of BELLEMERE (1967), LETROUIT-GALINOU (1969) and HERTEL (1967) the ectal and the medullary excipulum together are called amphithecium. Thus defined, the amphithecium does not necessarily contain algae, and is not identical with a thalline margin, a sense in which it is often used. In the author's opinion the term thalloid amphithecium is preferrable to indicate an amphithecium which contains algae, and the term thalline margin is better restricted to thalloid structures in the ascocarp which are derived directly from the thallus, e.8. in the apothecium of the Parme Ziaceae (HENSSEN \& JAHNS 1973, p. $194 \mathrm{f} . \mathrm{f}$.$) , not from the primary corpus as in the case of the Megalosporaceae.$

An amphithecium seems to be a very frequent structure in the Lecanorales. For instance, LETROUIT-GALINOU (1966) described it for Lecanora subfuscata and Lecidezla ezaeochroma. In the present study it has been found, in a more or less well developed state, in all investigated species (as cited on p. 21-22). Sometimes it is reduced, e.g. in Pertusamia (HENSSEN \& JAHNS 1973, p. 360) or replaced by a supporting structure of different structure, as in the Parme iiaceae (HENSSEN \& JAHNS 1973, p. 295).

7a. SUBHYPOTHECIUM. This is the part of the excipulum that lies adjacent to the hypothecium. In Megalosporaceae it consists of compacted, irregularly orientated thick-walled hyphae which contrast with the thin-walled hyphae of the hypothecium and the arachnoid tissue of the medullary excipulum. The subhypothecium hyphae are often enveloped in pigment. In Megalosporaceae this pigment is either black-brown (P1. $6 \mathrm{D}$ ), and then usual1y present in a thick layer and sometimes penetrating into adjacent zones, or orange-brown, and then present in only a thin layer below the hypothecium. The latter type of pigment is best observed in fresh sections in water-mounts under the stereomicroscope with incumbent light, and disappears during the preparation of permanent mounts.

The subhypothecium is little developed in the investigated species with leca- 
norine apothecia, mentioned on $p .26,8 u b 5$. In these it is confined to a mass of hyphae which plug the central opening in the parathecium.

The observation of pigmented hyphae in the hypothecium suggests that subhypothecial hyphae penetrate into the hypothecium. Probably this explains the illdefined limit between hypothecium and subhypothecium, and the presence of widecelled remains of the ascogenous apparatus in the upper part of the dark-brown subhypothecium in Megaloblastenia marginiflexa. The compact tissue that fills up the whole central part of the apothecium in Bacidia obscurata is probably due to a very strong development of the subhypothecium.

The subhypothecium might be homologous with the podium. However, the ontogeny of the subhypothecium is not clear. It does not seem to be directly produced by the parathecial crown, as do the hymenium and the amphithecium. In Megalosporaceae the subhypothecium is generally thin and it has not been observed in young stages of the developing apothecium (cf. p. 34). Most likely it originates from hyphae of the medullary excipulum which form a compact layer adjacent to the hypothecium. In Megaloblastenia marginiflexa var. manginiflexa, where the subhypothecium is often darkbrown and thus easily recognisable, it is already visible in the youngest apothecium as a patch of brown-pigmented hyphae below the remnants of the primary corpus ( $P 1$. $16 \mathrm{~B}$ ). This darkbrown patch resembles the podium as described by LETROUIT-GALINOU (1966, p. 455) for Lecidelza elaeochroma ("Lecidea elaeochroma") and by HENSSEN (1968, P1. Ile) for Buelzia disciformis. According to LETROUIT-GALINOU (1966, P1, XI, fig. B) the podium of Lecidelta elaeochroma originates from the pericentral floor.

The term podium has also been used by BELLEMERE (1967) for non-lichenised ascomycetes. He considers it to be derived from the subhymenial net ("réseau sous-hymeniale"), a layer above the pericentral floor ("plancher"). In Megalosporaceae there is no clear difference between a pericentral floor and a subhymenial net (see p. 31). This fact and the late appearence of the subhypothecium make it difficult to decide whether the subhypothecium is homologous with the podium as understood by BELLEMERE. Because of this ambiguity and the fact that the subhypothecium has no foot-like appearence, the term podium has not been used here.

7b. MEDULLARY EXCIPULUM. This forms the inner part of the amphithecium, with an arachnoid structure (ANDERSON 1964).

7c. ECTAL EXCIPULUM. This concerns the outer, compact layer of the amphithecium (ANDERSON 1964). In MegaZosporaceae it has an anticlinal arrangement of the hyphae, because the ends of the excipulum hyphae are at right angles to the sur- 
face.

8. ATTACHMENT LAYER. This term is introduced here for a layer constantly present in Megalosporaceae, which appears to be as yet unnamed. It relates to a ca. 10$20 \mu \mathrm{m}$ thick layer of thin-walled hyphae covering the surface of the ectal excipulum and extending to the thallus (Pl. $6 \mathrm{E}$ ). Thus it forms an additional attachment for the apothecium, which probably compensates for the narrow apothecium base (p. 29). The hyphae of the attachment layer seem to originate from a renewed growth of the ectal excipulum. They differ from the excipular hyphae by being not inflated and thin-walled. Occasionally attachment layer hyphae have been observed which form a continuation of ectal excipulum hyphae (P1. 7 B). Such a renewed growth of excipulum hyphae is in contradiction with DUGHI (1954, p. 306), who states that the excipulum tissue in lecideine apothecia looses the capacity for further growth. A renewed growth of excipular hyphae is also observed by SWINSCOW \& KROG (1981, fig. 13) for e.8. PhyZlopsora santensis.

A similar attachment layer has also been observed in Bacidia muscomom, $B$. obscurata, Cliostomm griffithii, Lecidea caesioatra, Lecidella elaeochroma, Letrouitia domingensis, Rinodina miaraea and, less clearly, in Lecanora subfuscata. Thus its presence is widespread.

An extended attachment layer occurs in Megalospora coccodes, M. pachycheiza and $M_{*}$ pruinata. It concerns an attachment layer which extends further than usual along the ectal excipulum, is to $50 \mu \mathrm{m}$ thick and contains algae. Externally it is already visible as a thalloid cover on the apothecial margin. In structure it differs from a thalloid amphithecium because the hyphae form a compact tissue, as usual in the attachment layer, and no arachnoid tissue, and because the ectal excipulum remains clearly distinct below it (P1. $7 \mathrm{C}$ ). The origin of its algae has not been investigated.

9. ANCHORAGE BUNDLES. This concerns also a new term, for a structure which is of general occurence within the investigated Leconorales. The anchorage bundles consist of thin-walled, not swollen hyphae which are directed into the medulla of the thallus, where they can be traced in bundles below and sometimes beyond the apothecium (P1. $6 \mathrm{E}$ ). They penetrate also into the bark tissue of the host. In large apothecia bark cells appear to be pushed upwards by the bundles, thus forming a tubercle. Inside the apothecium the bundles dissolve abruptly in the medullary excipulum, but some of their hyphae can be traced into the subhypothecium (P1. $6 \mathrm{~F}$ ).

10. APOTHECIUM BASE. This term is introduced here for a common structure in lecideine and biatorine apothecia, the plane surrounded by the ring of the oldest excipulum tissue. Because younger parts of the excipulum are formed distally, 
the apothecium base is enclosed by the oldest excipulum parts, and constitutes the primary connection between the apothecium and the thallus. Usually anchorage bundles (9) run through it.

In young apothecia the apothecium base is a narrow structure, often c. 200 m wide. During the growth of the apothecium it disrupts and widens to c. $500 \mathrm{\mu m}$, probably by the enlargement of the anchorage bundles. Then the older parts of the ectal excipulum are obscure.

\section{E. Ontogeny and development of the apothecium}

The principal studies on the ontogeny of lichen ascocarps are by LETROUITGALINOU (1966) and HENSSEN (e.g. HENSSEN \& JAHNS 1973). These authors used somewhat different techniques for their ontogenetic investigations, and consequently have introduced a different terminology.

LETRUIT-GALINOU used paraffin sections with several staining techniques. In this way she was able to give very detailed descriptions of the developments, in a rather small number of species. HENSSEN used thicker cryotome sections, stained with lactophenol-cotton blue. In this way less information is obtained about cytological and chemical differences between the hyphae, and their exact course. But this more rapid method enabled her to study a wider range of species (in part unpublished). For a review see KEUCK (1977), who gives a conversion table for the terminology used by both authors.

In the present study the English terminology of LETROUIT-GALINOU (1969) has been adopted as follows:

I. primordium: the youngest stage in the ontogeny, in which an undifferentiated aggregation of more intensily staining hyphae is present.

II. primary corpus: in this stage a first differentiation has taken place. The ascogonial apparatus is present, and the first traces of excipulum or paraphyses become visible. The terms of LETROUIT-GALINOU for structures within the primary corpus have not been used because they could not be identified with certainty in the investigated material.

III. young apothecium: in this stage the form of the apothecium becomes recognisable, with an excipulum and a paraphysal layer. Internally the remants of the primary corpus disappear.

Because the ontogenetical stages are infrequent and their investigation timeconsuming, not all treated species have been investigated. The following species have been examined: Austroblastenia pauciseptata (from New Zealand, Sipman 16839 (U)), A. pupa (from New Zealand, Sipman 16081B, 16779 (U)), Catinomia 
versicolor (from Brasil, Sipman 12938 (U); from Colombia, Sipman 10304 (U); from Guatemala, Hale 43830 (US); from Venezuela, Hale 44002 (US) \& López 21542, 22801 (MERF)), Lecania sulphureofusca (from Colombia, Sipman 10368 (U)), Megaloblastenia marginiflexa (from Brasil, Malme L-799 (S), Puiggari 1522 (G) \& Sipman 13035 (U); from New Zealand, Tucker 20264 (LSU)), Megalospora gompholoma (from New Zealand, Knight s.n. (H) \& Tucker 20264 pr.p. (LSU)), M. sulphurata (from Brasil, Sipman 12929, 12938, 12943, 13088 (U); from Indonesia, Anon., 910,2011893 (L)), M. tuberculosa (from Brasil, Sipman 12727, 12728, 13027, 13942 (U)).

A reconstruction of the development in the examined species has been made by arranging of the stages encountered. Of some stages several examples were present, thus some indication of the range of variation in the development of particular species has been obtained.

To find the youngest stages, marginal parts of the thallus with recognisable initials have been sectioned, but usually only primary corpus-stages have been found. Since the lactophenol-cotton blue staining is not very suitable to study nuclei, it was difficult to recognise the ascogonial and the sporophytic apparatus. Neither could be detected whether the full life cycle with polynucleate sporophyte I (LETROUIT-GALINOU 1974) occurs or whether some reduction in the life cycle has taken place. The presence of ascogonia has been ascertained by the observation of trigogynes, which are easily detectable as thick, well-stained filaments leading to the thallus surface and extending about 20 m beyond it.

The following ontogenetical reconstructions have been made: Megalospora sulphurata (Fig. 2, P1. 12, 13)

I. Primordium stages, consisting of an undifferentiated glomerule of hyphae surrounding ascogonium initials has not been found, probably because it is of short duration.

II. The youngest stages of the primary corpus available (Fig, 2 A, P1, 12 A, B) are recognisable on the surface of the thallus as minute brown-black dots, very much resembling the pycnidia but less protruding. They are more or less globose, c. $100 \mu \mathrm{m}$ in diameter, and centered in the algal layer. Their upper side reaches the surface of the thallus and their lower side extends to the substrate if the thallus is not too thick.

Anatomically they consist of three layers: 1. a thin basal layer, c. $10 \mathrm{~mm}$ thick, composed of thin, more or less horizontal hyphae; 2. a c. $50 \mu \mathrm{m}$ thick middle layer of vertically aligned, thin hyphae, c $1.5 \mu \mathrm{m}$ thick, which include a few wide-celled, short hyphae, c. $2.5 \mu \mathrm{m}$ thick, probably ascogonial initials; 
A

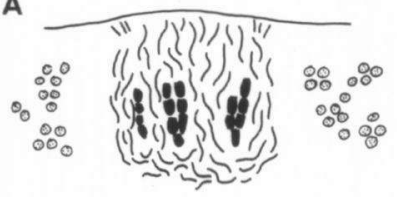

गागा7ग
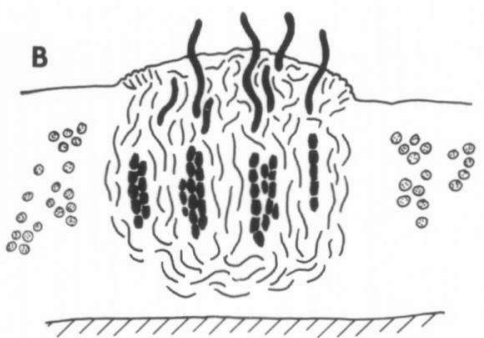

C

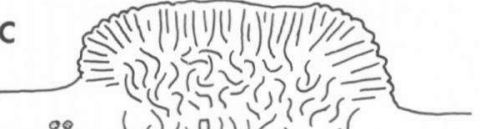

D

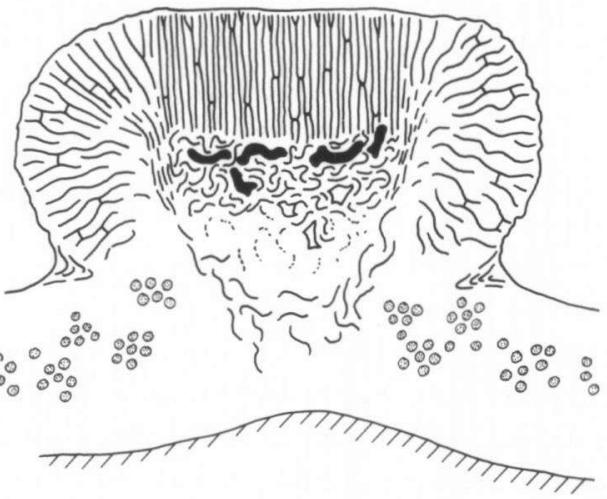

$\mathbf{E}$

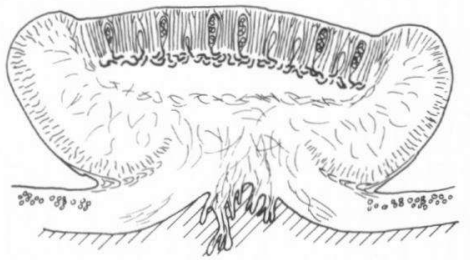

$\mathbf{F}$

$$
\text { (1) }
$$

17717171717171717178
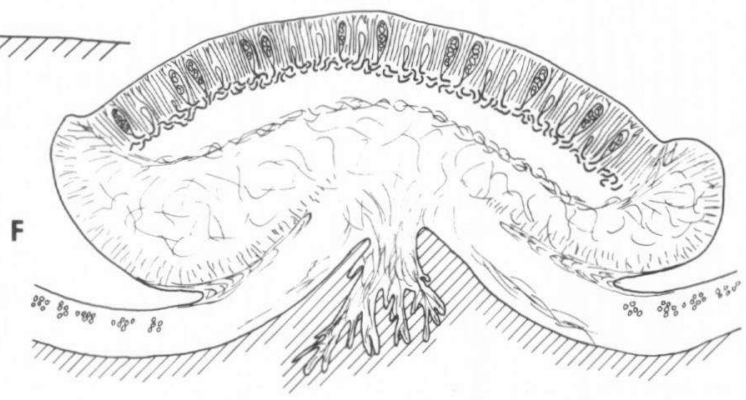

Figure 2. Ontogeny and development of the apothecium in Megalospora sulphurata. schematically. A, B. primary corpus stage; C. youngest apothecium stage; D. young apothecium; E. adult apothecium; F. old apothecium. 
3. a c. $40 \mu \mathrm{m}$ thick upper layer, which consists only of vertically aligned, thin hyphae. Near the surface the primary corpus shows a brownish pigment. Already in this stage the first traces of a parathecial crown may be present.

III. Larger stages of the primary corpus, c. $150 \mu \mathrm{m}$ in diameter (Fig. 2 B, P1. $12 \mathrm{C}, \mathrm{D})$. These exhibit some changes in the middle and upper layer. In the middle layer the wide-celled, short hyphae increase in number and length. They are single or in bundles, and composed of c. 5 cells with lumen c. 5.0-6.5 x 2.5-3.5 $\mathrm{mm}$. From their top trichogynes may originate. These trichogynes are $c$. $3.5 \mu \mathrm{m}$ thick, with lumen c. $1.5 \mu \mathrm{m}$ wide. They are slightly winding ("geschwungen", JAHNS 1970, p. 19) and extend up to $30 \mu \mathrm{m}$ beyond the surface of the tha11us. In the upper layer of the primary corpus the texture of the hyphae becomes irregular and not parallel. The increase in length of the primary corpus is mainly due to an increase in size of the middle layer. This suggests that the ascogonia have grown into the upper layer of the young primary corpus, and that a new upper layer of different texture has been formed above it.

An excipulum is present in about half of the examples observed of this stage. It starts as a ring around the upper side of the primary corpus, which consists of obliquely outward-directed hyphae. These hyphae extend beyond the thallus surface and form the initial parathecial crown. It is unclear whether this beginning of the parathecial crown is formed only by hyphae from the primary corpus, or if any thalline hyphae participate in it. The latter case is suggested by the observation of periclinal bundles of hyphae in the medullary layer of the thallus which turn upward near the primary corpus towards the parathecial crown (cf. P1. 14 D). However such a situation could not be observed in all examples.

The increase in width of the primary corpus suggests that during the development new ascogonia are added laterally. The commonness and large size of the primary corpus in the investigated lichen samples suggest that it is of long duration and continues to produce ascogonia and trichogynes over a long period of time. This feature constitutes a difference with most other lichens, where the rarity of initial stages has lead e.g. WOLFF (1905) to the conclusion that these stages develop in a short time.

IV. The youngest apothecia, c. $200 \mu \mathrm{m}$ wide and $150 \mathrm{\mu m}$ high (Fig. $2 \mathrm{C}, \mathrm{P1}$. $13 \mathrm{~A}$ ) shows a marked development of the excipulum, caused by an increase in number and length of the obliquely outward-directed hyphae. The enlarging excipulum extends upwards above the thallus surface. The upper surface of the young fruit remains flat in this stage, or slightly convex, by the development simultaneous with the excipulum of a layer of vertical, thin hyphae on the upper side of the primary 
corpus: the initials of the paraphyses. This layer is not clearly separated from the irregular uppermost layer of the primary corpus, and probably develops out of it by stretching. Thus the excipulum and the hymenium are developed above the thallus surface. No clear ascogonia are discernible in the remains of the primary corpus any more. Any thick hyphae present are aligned more or less horizontally and presumably constitute the initials of the sporophytic apparatus.

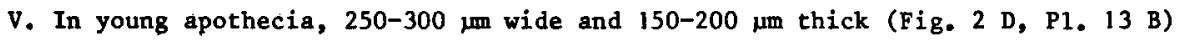
the remnants of the primary corpus have become conical, with the flat side towards the base of the young paraphyses. The excipular hyphae have increased considerably in length. The remnants have been elevated above the level of the a1gal layer, probably because an increase in thickness of the excipulum pushes the apothecium upwards. Anchorage bundles have become apparent. The hyphae in the remnants of the primary corpus exhibit a weak affinity to cotton-blue, like those in the hypothecium. In the basal part of the paraphysal layer ascogenous hyphae can be seen and on the lower side of the excipulum the first traces of an attachment layer become visible.

VI. In adult apothecia, over 500 $\mathrm{mm}$ wide and 250-600 $\mathrm{mm}$ thick (Fig. $2 \mathrm{E}$, P1. 5 A) the excipulum has become differentiated into an ectal part, a medullary part and a subhymenium. A flat hypothecial layer is present below the layer with ascogenous hyphae and the remnants of the primary corpus have disappeared completely. At this stage deposits of calcium-oxalate may accumulate in the medullary excipulum. The diameter of the apothecium base has increased. The increase in thickness of the adult apothecium is caused mainly by the increase of the medullary excipulum. The other layers show only little increase in thickness. No living algae are retained in the thalline parts that have become overgrown by the apothecium.

The growth of the hymenium occurs in Megalospora sutphurata apparently by the formation of new paraphyses along the margin, from the parathecial crown (p. 26). It is unlikely that the hymenium is added to by the production of new intercalary paraphyses: no such young paraphyses could be observed.

VII. In old apothecia, usually over $2 \mathrm{~mm}$ wide and as thick as $750 \mu \mathrm{m}$ (Fig. $2 \mathrm{~F}$, P1. $13 \mathrm{C}$ ) the disc is often convex. This is not caused by increase in thickness of the apothecium but by curling of the excipulum, accompanied by a raising of the substrate into a tubercle. The apothecium base may have increased to 500$900 \mu \mathrm{m}$ in width.

VIII. In degenerating apothecia the hymenium dies and the remnants of the apothecium are overgrown by the thallus. Partial regeneration has been observed 
occasionally.

The description of the young stages is based on two examples of the young primary corpus, six of the larger primary corpus, one of the youngest apothecium and two of the young apothecium

MEGALOSPORA GOMPHOLOMA (P1. 14)

The development shows the same pattern as described above for Megalospora sulphurata, except for the following differences:

- No distinction between younger and older stage in the primary corpus could be made, because in all examples the upper layer was composed of irregularly orientated hyphae (P1. $14 \mathrm{~A}$ ).

- The size of the primary corpus can be considerably larger, c. $200 \mu m$ in diameter. This larger size is mainly due to a thicker central layer, where the ascogonia are more scattered, occuring at various levels.

- Excipulum development may coincide to a variable degree with the presence of ascogonia. In one example ( $\mathrm{P} 1.14 \mathrm{C}$ ) well developed ascogonia with extending trichogynes were enclosed by an excipulum already $160 \mu \mathrm{m}$ high and $100 \mu \mathrm{m}$ thick. The primary corpus of this example measures c. $200 \mathrm{~mm}$ in diameter and there is still no paraphysal development. On the contrary in another example (P1. 14 B) a stage measuring $210 \times 180 \mu$ was present which already approached the young apothecium, with clearly developed paraphyses and remnants of a primary corpus measuring $160 \times 75 \mu \mathrm{m}$.

The young apothecia are about $500 \mu \mathrm{m}$ wide and $200 \mu \mathrm{m}$ thick, the adult ones over $1 \mathrm{~mm}$ wide and $500 \mu \mathrm{m}$ thick, the oldest up to $2.5 \mathrm{~mm}$ wide and $550 \mu \mathrm{m}$ thick with a base widened to c. $500 \mathrm{~mm}$. Plate $14 \mathrm{D}$ shows the presence of periclinal bundles of hyphae turning upward from the thallus to the beginning parathecium, which suggests that the latter is not composed only of hyphae from the primary corpus.

In one primary corpus of a slightly decayed specimen a few trichogynes were present extending above the thallus surface, which were covered with a large number of elongate bodies. Judging from their size the bodies seem to represent degenerate pycnospores, though their contours are not very sharp any more. This observation suggests that in Megalospora the pycnospores function as spermatia.

The following numbers of examples have been used: primary corpus, 5; youngest apothecium, 1; young apothecium, 3. 


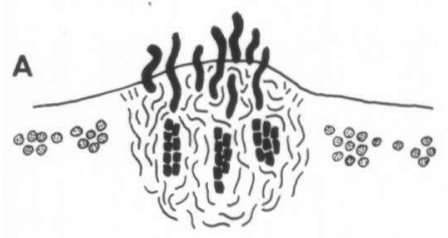

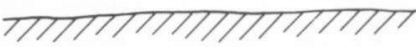

B

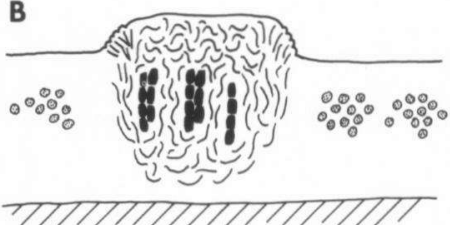

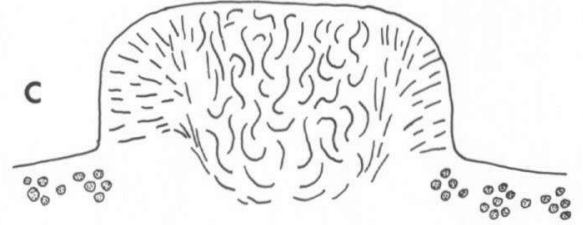
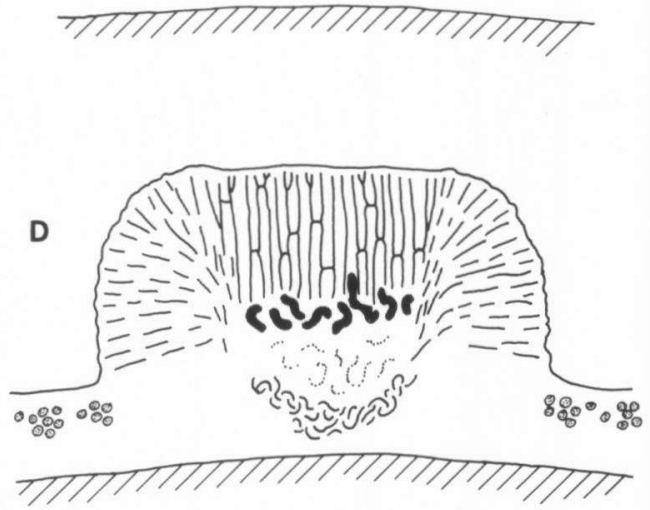

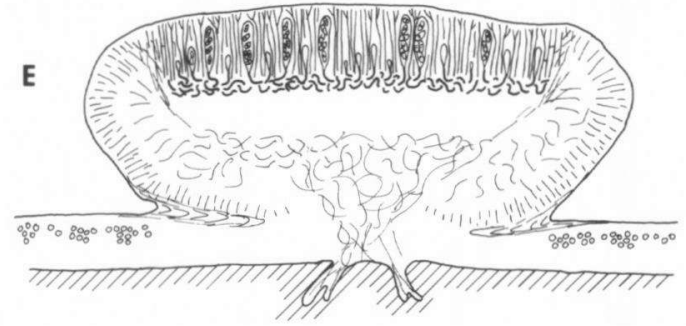

Figure 3. Ontogeny and development of the apothecium in Megazoblastenia marginiflexa, schematically. A, B. primary corpus stage; C. youngest apothecium stage; D. young apothecium; E. adult apothecium. 
MEGALOSPORA TUBERCULOSA (P1. 15)

Like in the foregoing species the development follows the same pattern as in Megalospora sulphurata, with still less differences: The primary corpus remains smal1, up to $100 \mathrm{~mm}$ wide, and the hyphae in its upper layer are more parallel aligned ( $\mathrm{P} 1,15 \mathrm{~A}, \mathrm{~B}$ ).

The numbers of available examples were: primary corpus, 3; young apothecium, 5.

\section{AUSTROBLASTENIA PAUCISEPTATA, A. PUPA}

In these species primary corpus-stages have been found which resemble closely those in Megalospora sulphurata. MEGALOBLASTENIA MARGINIFLEXA (Fig. 3, P1. 16 A, B)

I. The earliest stage distinguishable was the primary corpus (Fig. $3 \mathrm{~A}, \mathrm{Pl} .16$ A). On the thallus surface it shows as a minute, weakly pigmented spot, the tip often covered by tomentum. Anatomically it is nearly sphaerical, c. 100-150 $\mu \mathrm{m}$ in diameter. Its upper side reaches the thallus surface, its lower side the substratum when the medulla is not too thick. Internally three layers can be distinguished: a thin basal layer of thin, more or less horizontal hyphae, a c. $50 \mu \mathrm{m}$ thick middle layer consisting of thin, more or less vertical hyphae accompanied by groups of straight ascogonia, and a thick upper layer of irregularly orientated, thin hyphae. In case the parallel arrangement of the hyphae in the middle layer is less obvious, an outer sheath of parallel hyphae around it can be discerned. The ascogonia consist of short, wide-celled, nearly straight, vertical hyphae composed of c. 5 cells measuring $3 \times 4.5-5.5 \mu \mathrm{m}$. From their tips slightly winding trichogynes direct to the thallus surface. The trichogynes are c. $3 \mu \mathrm{m}$ wide and extend up to $20 \mu \mathrm{m}$ above the thallus. Sometimes the surface above the primary corpus is covered with dead trichogynes, appearing like a tomentum (P1. $16 \mathrm{~A}$ ).

The primary corpus is apparently of long duration in view of its frequency: some thalli are nearly covered with them.

II. The transition to the young apothecium is represented by a c. $200 \mu \mathrm{m}$ wide stage (Fig. 3 B) with development of an exipulum. This starts with a parathecial crown in a ring around the upper side of the primary corpus. From the parathecial crown the first excipular hyphae radiate outward. In this stage the inner parts of the young fruit have the same structure as the primary corpus. III. In stages of c. 200-250 $\mu$ width (Fig. $3 \mathrm{C}$ ) an excipulum has been formed which measures already $100 \mu \mathrm{m}$ in height, but no clear paraphysal layer of parallel texture can be distinguished yet. Either the initial paraphyses do not show 
such a parallel orientation because of the presence of many anastomoses, or paraphyses are still absent and the extending excipulum surrounds an exserted part of the primary corpus.

IV. When the young apothecium is about 250-300 $\mu \mathrm{m}$ wide (Fig. 3 D) the paraphysal layer becomes distinct, but is still rich in anastomoses. The excipulum has not developed much further, but a subhypothecium becomes apparent, especially in the specimens of Megaloblastenia marginiflexa var. marginiflexa, where it is brownpigmented. The subhypothecium penetrates into the lower parts of the remnants of the primary corpus, as can be concluded from the presence of wide-celled inclusions. The other parts of the primary corpus assume the structure of a hypothecium, with in this stage a rounded lower face and a flat upper face.

V. In adult apothecia, over $300 \mu \mathrm{m}$ wide and $300 \mu \mathrm{m}$ thick (Fig. $3 \mathrm{D}$, P1. $8 \mathrm{~A}, \mathrm{C}$ ) the excipulum has become differentiated into a medullary and an ectal part. The subhypothecium assumes a conical shape with its point touching the substrate and sometimes taking part in the formation of the anchorage bundles (Fig. 3 E, P1. $8 \mathrm{c}$ ). An attachment layer is present, and the width of the apothecium base is increased to c. $300 \mathrm{\mu m}$.

The numbers of available examples were: stage I, 3; stage II, 1 ; stage III, 1 ; and stage IV, 1 .

Upon comparison with Megatospora it becomes clear that the development follows much the same pattern, especially as regards the structure and persistence of the primary corpus and the ascogonia. The main differences are the earlier and stronger development of the subhypothecium and the later development of the paraphyses.

CATINARIA VERSICOLOR (Fig. 4, P1. $16 \mathrm{C}, 17$ )

I. The youngest stage is probably represented by two examples (Fig. 4 A, P1. $16 \mathrm{C}, 17 \mathrm{~A}$ ), which show on the surface of the thallus as minute, black, not protruding dots. Anatomically they consist of a glomerule of dense, coiling, c. $1.5 \mu \mathrm{m}$ thick hyphae which is situated on the level of the algae, with its top c. $15 \mu \mathrm{m}$ below the thallus surface and measuring c. $70 \mu \mathrm{m}$ in height and $50 \mu \mathrm{m}$ in width. In the smaller example a more dense upper and lower part can be distinguished, in the larger example the whole glomerule is about evenly dense. Inside a few c. $2.5 \mu \mathrm{m}$ thick coiled hyphae are present, which probably represent the ascogonial or the sporophytic apparatus. This could not be decided by the absence of trichogynes. Along the surface of the thallus above the glomerule an area with pigmented hyphae is present. In the smaller example this area is 115 $\mu \mathrm{m}$ wide with a colourless centre and outside of this irregularly orientated 

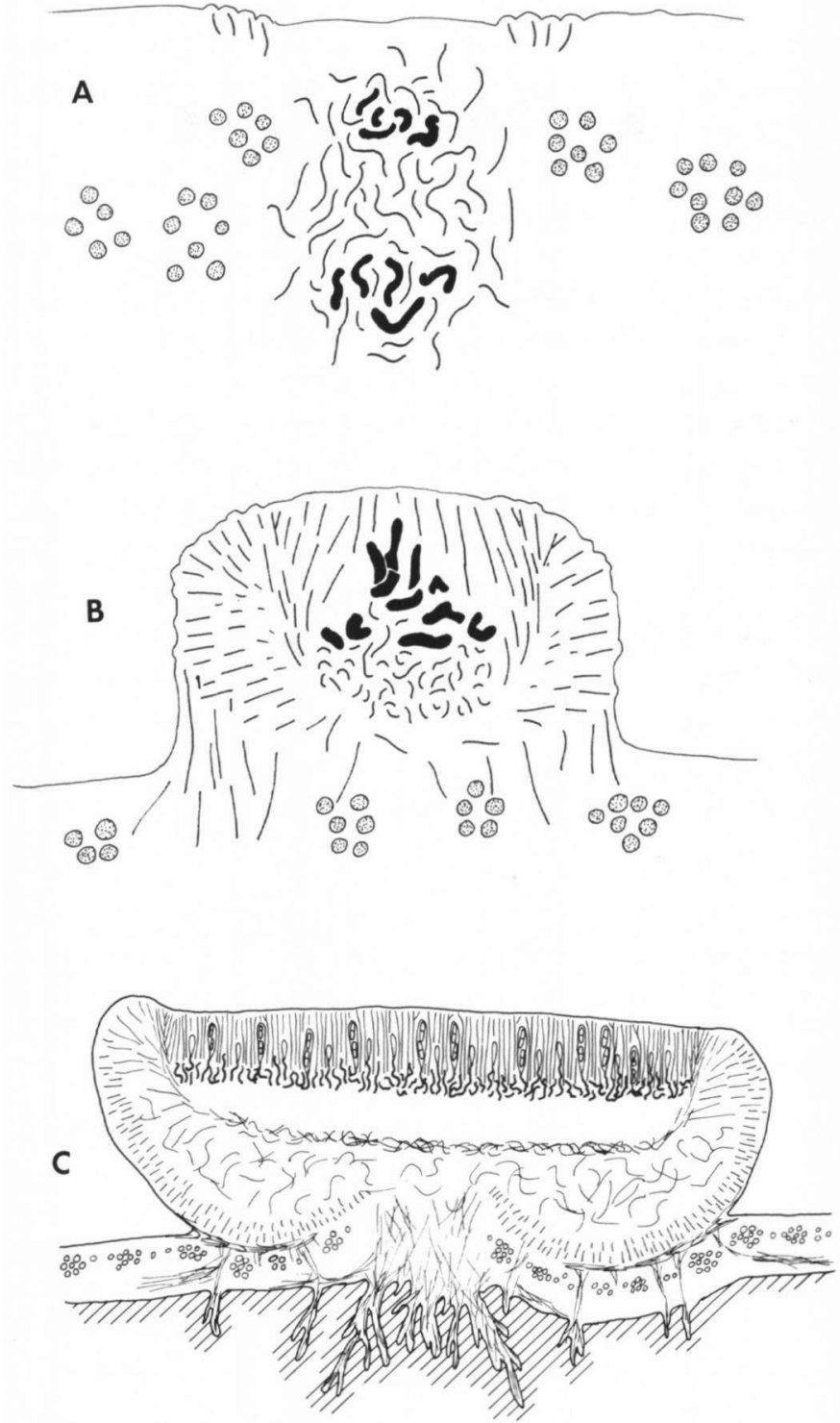

Figure 4. Ontogeny and development of the apothecium in Catinaria versicolor, schematically. A. primordium? B. young apothecium; C. adult apothecium. 
hyphae enveloped by pigment. In the larger example the area measures $185 \mu \mathrm{m}$ and is pigmented throughout, but with the pigment most concentrated around the upper ends of radiating hyphae which constitute a parathecial crown. Both examples probably represent the late primary corpus stage because the pigmented areas near the surface of the thallus seem to indicate the first development of the excipulum.

II. The youngest apothecium stages available, measuring 115 and $140 \mu \mathrm{m}$ in diameter (Fig. 4 B, P1, 17 B), show already a clearly developed excipulum which is elevated above the surface of the thallus, and a layer of paraphyses. Internally remnants of the primary corpus are indicated with coiled, thick hyphae which are probably ascogenous. No clear observation of paraphyses originating from remnants of the primary corpus could be made, thus probably all or nearly all paraphyses are derived from the parathecial crown.

III. In adult apothecia, measuring over $500 \mu \mathrm{m}$ in diameter (Fig. $4 \mathrm{C}, \mathrm{P1} .9 \mathrm{~A}$ ), a parathecium is present, an excipulum, a hypothecium, a subhymenium with ascogenous hyphae and a hymenium with paraphyses and asci. The excipulum is differentiated into a medullary and an ectal layer and a subhypothecium. In this stage also an attachment layer and anchorage bundles are visible. Part of the anchorage bundles arises from the attachment layer and invades the thallus ( $\mathrm{Pl}$. $9 \mathrm{E})$. The algal cells in the part of the thallus which becomes overgrown by the apothecium remain alive. The apothecium base is up to c. $350 \mu \mathrm{m}$ wide.

old apothecia become slightly convex in the same way as in Megalospora.

In two examples (P1.9 D) an apparently abnormal stage has been sectioned. It forms a nearly globular, exserted structure of radiating hyphae, not unlike the excipulum, without the normal disc-shape of the apothecium. Internally it is filled with a mixture of coiling thin and thick hyphae, the latter probably ascogenous. This globular stage may assume $460 \mu \mathrm{m}$ in diameter. This is much larger than the young apothecia of stage II, which already have well developed paraphyses.

The descriptions of the stages are based on the following numbers of examples: stage I, 2; stage II, 4. In spite of special attention no more examples of young stages could be found.

Upon comparison of the developments in Catinaria versicolor with Megalospora and Megaloblastenia it becomes clear that there are considerable differences. The most conspicuous one is the short duration of the primary corpus, which makes it of rare occurence in Catinaria versicolor. This rarity hampers further comparisons, because the observations are not sufficiently well-documented. 
The primary corpus apparently remains smaller, in view of the size of the young apothecia. If the thick, coiled hyphae in the glomerule of stage I represent ascogonia, these differ by being not straight but of the coiling type ("Schrauben", JAHNS 1970, p. 21). The hyphae which form the parathecial crown seem to be independant from the primary corpus. All paraphyses seem to originate from the parathecial crown. The excipulum base increases less in width and anchorage bundles are formed also by the attachment layer. The algae in the thallus below the apothecium persist.

LECANIA SULPHUREOFUSCA (Fig. 5, P1. 18)

In this species no primordium or primary corpus stages have been found. Even in specimens with very young apothecia no trace of them could be detected. This suggests that the occurence of these stages is of short duration.

I. The youngest stage observed, about $150 \mu \mathrm{m}$ wide (Fig. $5 \mathrm{~A}, \mathrm{P} 1.18 \mathrm{~A}$ ), shows an early apothecium. On the thallus it is marked as a slightly raised area where the thallus is cracked. It is immersed in the thallus, below the algal layer, which has broken open above it. Anatomically a peripheral and a central part can be distinguished. The peripheral part consists of a layer of parallel, vertical hyphae measuring c. $25 \mu \mathrm{m}$ in thickness, which ends in the initials of the parathecium, with a parathecial crown on top. The central part, measuring c. $90 \mu \mathrm{m}$ in diameter, consists of three layers: a layer of young paraphyses; a young subhymenium with thin and thick, irregularly orientated hyphae, the latter probably ascogenous; and at the base a conical hypothecium. On the analogy with Megalosporaceae this conical hypothecium supposedly represents the remains of the primary corpus. If this is true, the primary corpus must have developed in the medullary layer of the thallus, not in the algal layer as in Megalosporaceae. II. In a later stage of the young apothecium, measuring c. $250 \mu \mathrm{m}$ in width (Fig. $5 \mathrm{~B}, \mathrm{P} 1.18 \mathrm{~B}$ ), a clear parathecium and a well developed parathecial crown are present. The thallus is pushed upwards by the growing apothecium to form a rim around the parathecium. Thus the algal layer comes in close contact with the parathecial crown. In this contact zone the algal cells are smaller and more numerous, which is an indication for multiplication (P1. $18 \mathrm{C}$ ). III. In a still larger stage of the apothecium, c. $450 \mu \mathrm{m}$ wide (Fig. $5 \mathrm{C}, \mathrm{Pl}$. $18 \mathrm{E})$, a lecanorine margin has formed. Internally a well developed parathecium is present, from which hyphae direct obliquely into the algal layer (P1. $15 \mathrm{C}$ ). At the top of the parathecium a very pronounced parathecial crown is present, which is in close contact with a site of small, apparently multiplying algal ce1ls. No subhypothecium is observable and a parathecium consisting of parallel hyphae is distinct from the parathecial crown to near the base 

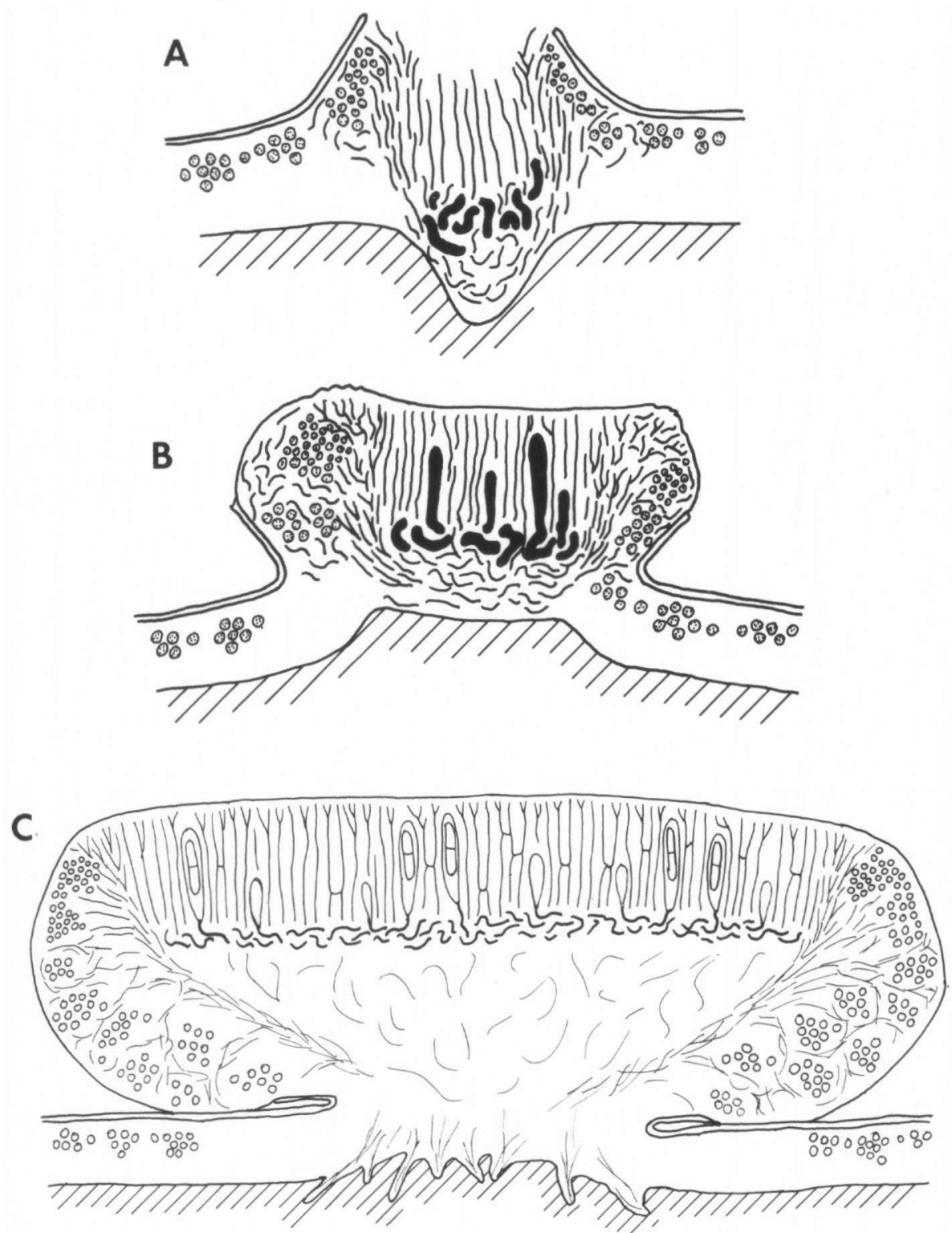

Figure 5. Development of the apothecium in Lecania sulphureofusca, schematically. A. youngest apothecium stage; B. young apothecium; C. adult apothecium. 
of the apothecium. The hypothecium is still more or less conical. In the apothecium base a tissue is present of irregular hyphae which direct partly into the substrate. No attachment layer is developed, and the apothecium base does not exceed c. $250 \mu$ m in width.

The oblique orientation of the hyphae from the parathecium into the lecanorine apothecium margin, in the same direction as in an amphithecium, and the multiplying algae next to the parathecial crown, suggest that in this species the thalloid margin is formed by excipular hyphae. The penetration of algal cells between the young excipular hyphae, which become split off from the parathecial crown, might be explained by pressure from the mass of multiplying algal cells next to the crown. Thus the lecanorine margin of Lecania sulphureofusca seems to be a thalloid amphithecium. The thallus-1ike appearence of it could be explained as a secondary feature caused by the interaction of the algal cells with the hyphae. Another origiu of the lecanorine margin is postulated by HENSSEN \& JAHNS (1973, p. 97) for Caloplaca cinnomomea. They observed that a growing thallus sheath envelops the growing parathecium. When applied to Lecania sutphureofusca this fails to give an explanation for the oblique arrangement of the hyphae which direct from the parathecium into the margin, especially near the parathecial crown.

IV. Adult apothecia, c. $1 \mathrm{~mm}$ wide (P1. $8 \mathrm{~B}$ ), do not show much differences when compared with stage III. An attachment layer is present, and in the incomplete base of the parathecium a subhypothecium can be observed. The apothecium base has not become much wider, and a mass of small algal cells next to the parathecial crown is present, with hyphae directing obliquely to it from the upper part of the parathecium (P1.8 E).

The descriptions of the first three stages are based on one example each.

Comparison of the ontogeny of Lecania sulphureofusca with Megalospora and Megaloblastenia indicates considerable differences. A persistent primary corpus appears to be absent, and the youngest ontogenetical stages of the fruitbody are formed below the algal layer. Unfortunately the structure of the primary corpus and the ascogonia is unknown. In later stages the development of a thalloid amphithecium is very conspicuous, the hypothecium long remains conical, and the apothecium base does not increase in width.

\section{F. Morphology of ascus and spores}

When containing ripe spores, the ascus is about 4-5 times as long as wide, and cylindrical to slightly clavate (Fig. 7-11). Its length is related to the 
hymenium height, because the tops of the asci are on a constant distance of $c$. $20 \mu \mathrm{m}$ below the surface of the disc. The wall of the ascus is usually c. $5 \mu \mathrm{m}$ thick, slightly thicker at the apex, with a distinct, up to c. $25 \mu$ m thick dome when the spore formation starts. Staining with I-solution shows that the wall consists of a thin, intensely stainable outer wall, c. $1 \mu \mathrm{m}$ thick, and a thick, weakly stainable inner layer. The innermost part of the dome may become more strongly stained, and around the dome a stainable gelatinous sheath is often present. The inner part of the dome shows sometimes an irregular ocular chamber and descends along the lateral walls of the ascus in a thin layer for about $15 \mu \mathrm{m}$. With the methods used no clear differences have been found between the ascus types of the investigated lichen species with large, bicellular spores. In all species the asci resemble the Lecanora-type (HONEGGER 1978, p. 49) but are larger than usual. According to HAFELLNER \& BELLEMERE (1982) the asci in Megalospora tuberculosa ("Bombyliospora pachycarpa") are characterised by having a thick, multilayered wall, and not forming a rostrum.

The spores of the Megalosporaceae show a wide range of variation. Eight types have been distinguished:

I. sulphurata-type (Fig. $6 \mathrm{~A}, \mathrm{P1}, 19$ ): spores short, at most twice as long as wide, usually curved and more or less reniform, uniseptate, with a clear, 1-3 $\mu \mathrm{m}$ wide, smooth or warted epispore, a c. $2 \mu \mathrm{m}$ thick wall and a c. $0.5 \mu \mathrm{m}$ thick septum with a thick ring around its attachment line and a small central pore. The number of spores per ascus varies between 1 and 8 , usually about 3-4. The size of the spores decreases with increasing number per ascus (cf. Fig. 8 I and $\mathrm{J})$. As this number varies within a single apotheciun, the spore size is equally variable.

II. atrorubicans-type (Fig, $6 \mathrm{~B}, \mathrm{P} 1,20 \mathrm{~A}-\mathrm{C}$ ): spores elongate, about three times as long as wide, straight, uniseptate, with a clear, 1-3 um thick, smooth or warted epispore, a c. $2 \mu \mathrm{m}$ thick wall and a c. $0.5 \mu \mathrm{m}$ thick septum without or with a thin thickened ring around its attachment line and with a small central pore. The spores are always single in the ascus.

III. tuberculosa-type (Fig. 6 C, P1. 20 D): spores elongate, about three to four times as long as wide, straight, bacillar-pluriseptate, usually with 5 to 11 septa, with a c. $0.5 \mu \mathrm{m}$ thick, smooth epispore, a c. $2 \mu \mathrm{m}$ thick wall and c. $0.5 \mu \mathrm{m}$ thick septa without thickenings and without or with only traces of a central pore. The spores are always single in the ascus. IV. coccodes-type (Fig. 6 D): spores resembling the tuberculosa-type but differing by the spores being curved and with several, usually 2-4, together in each ascus. The pores in the septa are more often distinct. 


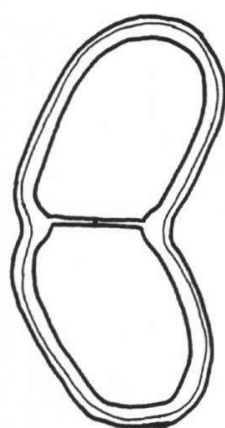

A

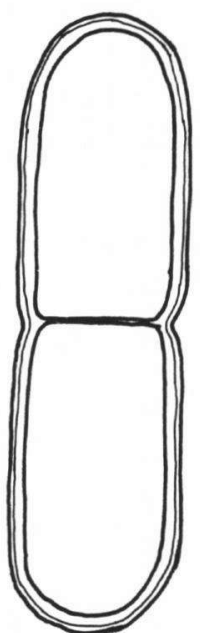

B
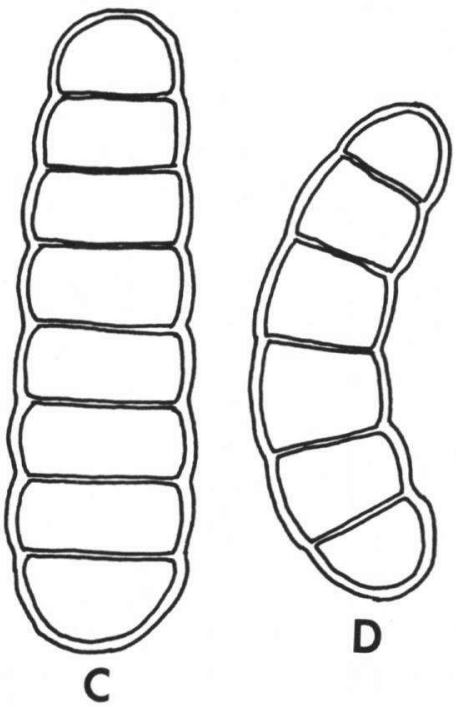

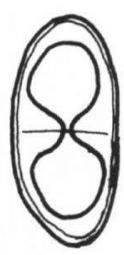

E

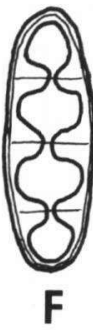

$\mathbf{F}$

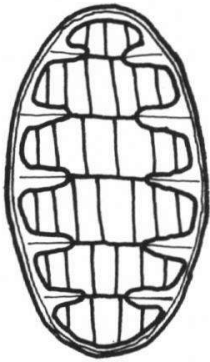

G

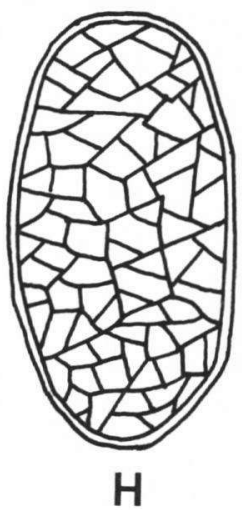

$\mathrm{H}$

Figure 6. Spore types in the Megalosporaceae. A. sulphurata-type; B. atrorubicans-type; C. tuberculosa-type; D. coccodes-type; E. albidula-type; F. pauciseptata-type; G. pupa-type; H. lopadioides-type. 
v. albidula-type (fig. 6 E, pl. $29 \mathrm{~F}-\mathrm{H}$ ): spores short, to twice as long as wide, straight or slightly curved, uniseptate, thick-walled with a c. $0.5 \mu \mathrm{m}$ thick outer layer, a c. $1.5 \mu \mathrm{m}$ thick inner layer which is to $3 \mu \mathrm{m}$ thick near the poles of the spore, and a c. 5-7 $\mu$ m thick septum with a wide central pore. The spores are with c. 4-8 together in each ascus. This type resembles the polarilocular spores of the Teloschistaceae, but differs by the presence of apical wall thickenings. It also resembles the Physcia-type spores (POELT 1965, p. 23), but differs from this by the absence of brown pigment. VI. pauciseptata-type (Fig. 6 F, P1. $21 \mathrm{~A}-\mathrm{B}$ ): spores elongate, about twice as long as wide, straight or occasionally somewhat curved, three-septate, thickwalled with a $1 \mu \mathrm{m}$ thick outer layer, a c. $1.5 \mu \mathrm{m}$ thick inner layer and c. $6 \mu \mathrm{m}$ thick septa with wide central pores. The spores are with (nearly) eight together in each ascus. This spore type resembles the spores in e.g. Caloplaca quadrizocularis (Ny1.) Zah1br. (HAFELLNER \& POELT 1979).

VII. pupa-type (Fig. 6 G, P1. 21 D-E): spores ovoid to nearly sphaerical, straight, muriform, thick-walled with a c. $1 \mu \mathrm{m}$ thick outer layer, a c. $1.5 \mu \mathrm{m}$ thick inner layer, c: $2 \mu \mathrm{m}$ thick transverse septa which are only $1 \mu \mathrm{m}$ thick in their central parts and c. $1 \mu \mathrm{m}$ thick longitudinal septa which seem to be restricted to the outer part of the spore. These spores are usually with 4-8 together in each ascus.

VIII. lopadioides-type (Fig, $6 \mathrm{H}$, P1, $21 \mathrm{C}$ ): spores ovoid, up to twice as long as wide, straight, muriform, with a $c .1 \mu \mathrm{m}$ thick wall, an indistinct or up to $1 \mu \mathrm{m}$ thick epispore or outer wall and c. $0.5 \mu$ m thick septa. This spore type occurs single in each ascus.

Constrictions do occur regularly at the septa, probably depending on the stage of the spore. Unclear is in how far the epispore in the sulphurata- and the atrorubicans-type are homologous with the outer layer of the spore wall in the albidula-, pauciseptata- and pupa-type. LINDSAY's (1866, p. 547) observation of bicellular spores who split into two separate cells has not been confirmed during the present study. Damage may cause breaking of the walls at any place but never splitting along the septum.

The thickness of the spore wall shows a considerable variation, which, however, is easily overestimated because of changes during the development of the spores. Unfortunately it is difficult to recognise the developmental stage in herbarium specimens, and to distinguish between full-grown spores and young or degenerate ones. In some preparations the discharge of many turgid spores with constricted septa suggests that these are the closest to ripeness. In many preparations only few spores leave the asci, probably by accident rather than 
in connection with their maturity. Such spores have of ten very thin or swollen and plicate septa and might represent young or degenerate (P1. 20 E) spores. Thus a study of the development and degradation of the spores in situ in hymenium sections appeared necessary. Such a study is favored by the fact that asci and spores in a wide range of developmental stages do occur together in the apothecia. Only the portion of asci in a certain stage may vary: in some specimens many ripe asci may be present, in others mainly young asci and degenerate spores.

\section{G. Development of asci and spores}

Because the development appeared to show little variation, only a few species are described here as examples. The reconstruction of the development is made by arrangement of stages according to their size. For the examination the sections have been prepared as indicated on p. 17. MEGALOSPORA GRANULANS, with atrorubicans-type spores (Fig. 7).

In young asci, about half of the adult size, the thickness of the walls increases gradually from the base to the apex, where there is a slight indication of an apical dome. When the ascus approaches its full size, the dome reaches its maximal thickness, with a usualiy indistinct ocular chamber and nearly evenly thickened lateral walls (Fig. 7 B). In such asci a small part of the cottonbluestained contents becomes surrounded with a thin wall, usually near the top. This spore initial measures c. $10 \times 5 \mu \mathrm{m}$. Successive stages show that this increases in size and becomes more elongate, until it nearly fills up the whole ascus. Then a thick spore wall becomes visible (Fig. 7 D) with an epispore. In this stage the dome is less thick then before. At last the septum is formed, beginning with a ring (Fig. $7 \mathrm{~F}$ ) and constricting untill narrow pore is left (Fig. $7 \mathrm{G}$ ). In fully ripe spores the septum is only slightly thickened. In old, decaying spores the wa11 and the septum become much swollen and the septum becomes folded as the spore collapses.

MEGALOSPORA CAMPYLOSPORA, with sulphurata-type spores (Fig. 8).

The ascus development is the same as in Megalospora granulans (Fig. $8 \mathrm{~A}-\mathrm{C}$ ). The spore initials are of about the same size but there are usually several of them in each ascus, though usually less then eight. The initials are of varying dimensions and in later stages the differences between the spores of the same ascus increase. Some spore initials evidently become aborted. Thus the eventual number of mature spores per ascus is very variable, even within a single apothecium. Generally the size of the ripe spores is correlated with the number per 

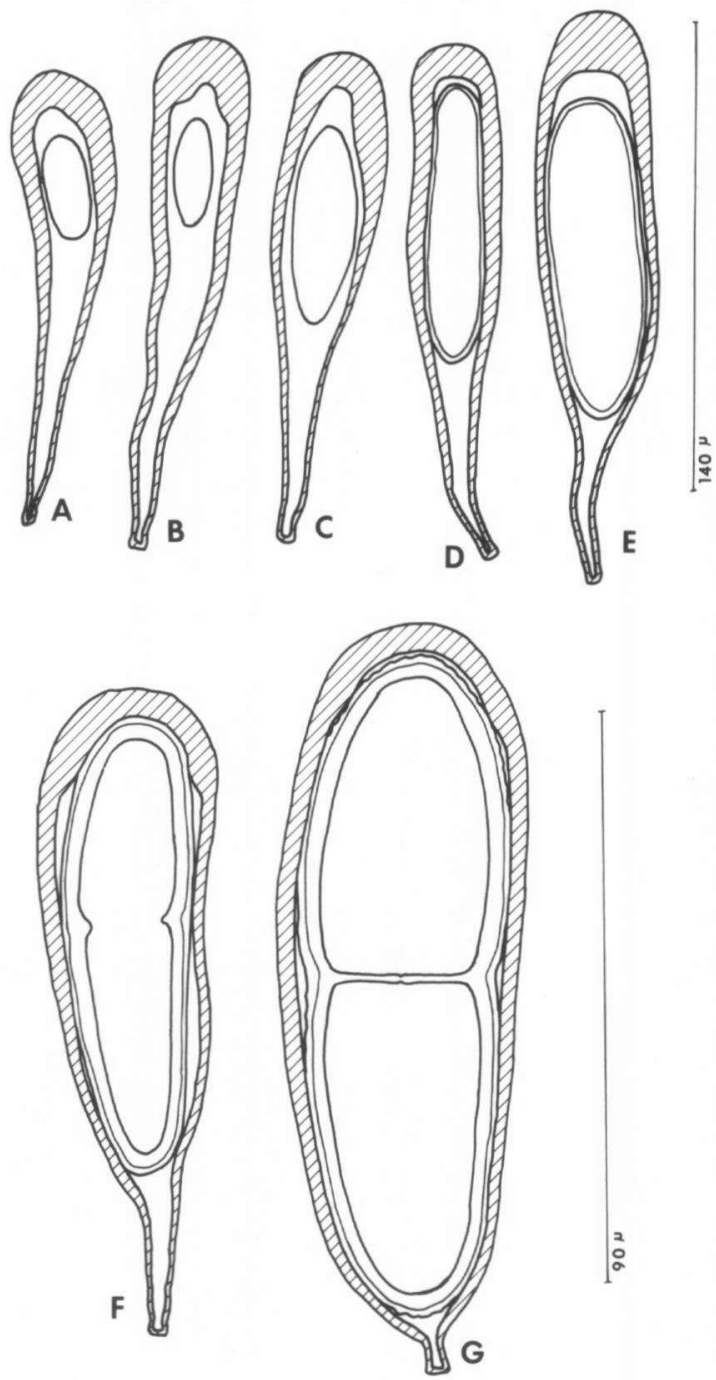

Figure 7. Development of ascus and spores in Megalospora granulans (Weber \& McVean $\mathrm{L}-48427,48670$ ). A-C. young asci with spore initials; D-F. asci with young spores; G. ascus with mature spores. 
morphology etc.
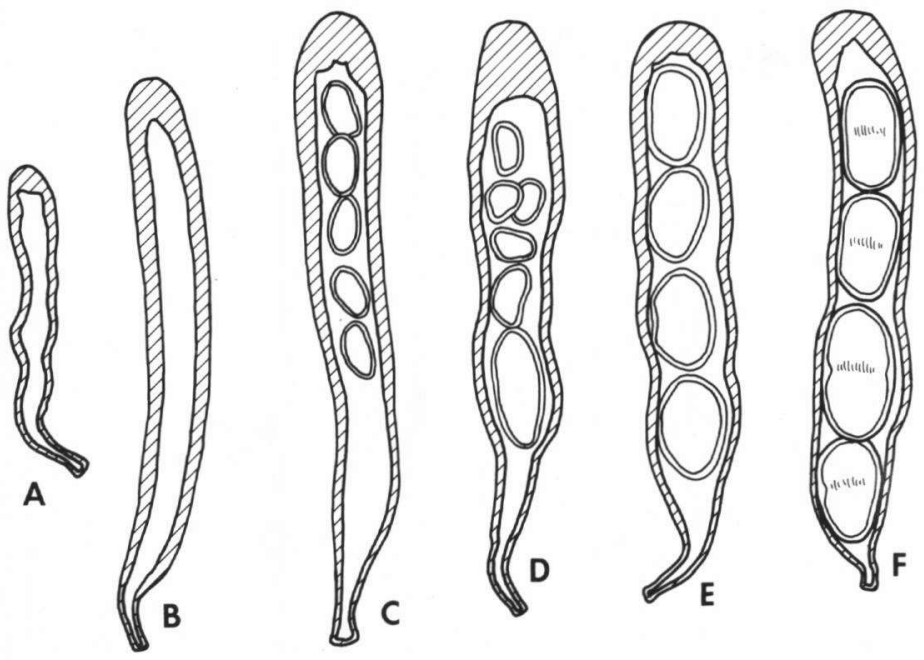

吕
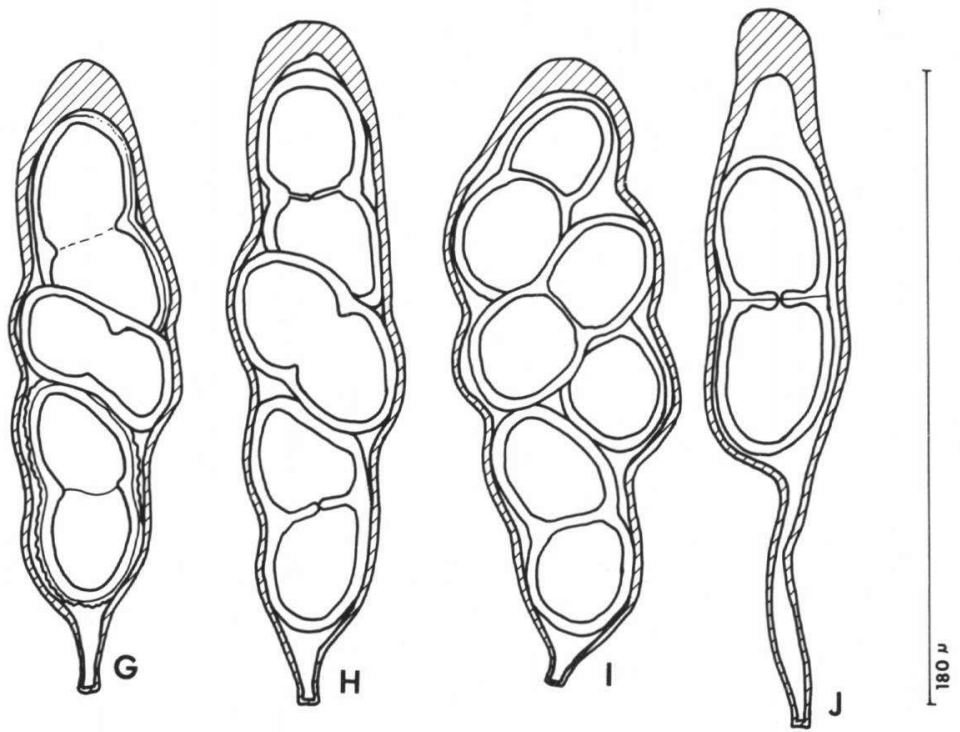

Figure 8. Development of ascus and spores in Megalospora campylospora (Prigley 3610 , Anon, in hb. Stirton 51). A, B. young asci; C-E. young asci with spore initials; F-H; asci with young spores; I, J. asci with mature spores. Note variation in spore number per ascus. 
ascus: when they are fewer in number, their size is larger (cf. .Fig. I and J). When the spores have attained their full size, the septum formation starts with a thick ring (Fig. 8 F-H). From this ring a thin septum grows by constriction. This septum increases slightly in thickness and leaves a small central pore. Degeneration features of old spores are the same as in Megalospora granulans. MEGALOBLASTENIA MARGINIFLEXA, with albidula-type spores (Fig. 9).

The young asci, up to half-size, have a c. $2 \mu \mathrm{m}$ thick wall and a hardly thicker apex. When the asci have reached their full size, the apical wall increases in thickness to about $20 \mu \mathrm{m}$, with a flat or rounded lower side and with or without an ocular chamber. In this stage the (usua1ly) eight spore initials appear, which are enveloped by a thin wall (Fig. 9 D). They measure about $10 \times 4 \mu \mathrm{m}$ in size. Afterwards they increase to about $17 \times 7 \mathrm{~m}$, and obtain a thicker wall, c. $1.5 \mathrm{~mm}$. Subsequently a strong increase in size occurs to the nearly adult size of c. $28 \times 12 \mu \mathrm{m}$. Then a further thickening of the spore wall internally can be observed, most strongly at both ends of the spores and in a ring on the place of the future septum. This thickening does not occur simultaneously for all spores in the same ascus. The earlier spores are often the larger ones. At last a septum is formed through the isthmus of the central thickening, and the spores reache their full width. The thickness of the septum and the width of the pore vary among spores of the same ascus, the thickness ranging from c. 4 to $7 \mu \mathrm{m}$, the width of the pore from 0.5 to $1.5 \mu \mathrm{m}$. The ascus apex is 1 ess thick now, c. $8 \mathrm{\mu m}$, and generally without ocular chamber. Degenerating old spores show a swelling of the wall and especially the septum.

CATINARIA VERSICOLOR, with spores resembling the atrorubicans-type (Fig. 10).

In young asci the walls are of about the same thickness throughout and the apex is hardly thicker than the lateral walls. When the ascus has attained nearIy its full length, the apical thickening becomes more pronounced but without ocular chamber. In such asci the spore initials appear (Fig. 10 B). There are mostly two of them in each ascus, measuring c. $20 \times 6 \mu \mathrm{m}$ and surrounded by a thin wall. Not infrequently only one spore initial is present and occasionally four have been observed in a single ascus. A few very sma11, apparently abortive initials measuring c. $6 \times 4 \mathrm{~m}$ are sometimes present in the earliest stages. These are then already much smaller than the others but show a wall. The normal initials grow to c. $40 \mathrm{~mm}$ in length, so that they together fill up nearly the whole ascus. Then a thicker wall becomes visible. When the spores have attained their full length, a septum is formed, without a clear preceding ring along the spore wall. The septum becomes c. $1.5 \mu \mathrm{m}$ thick, with a central pore. In fully 


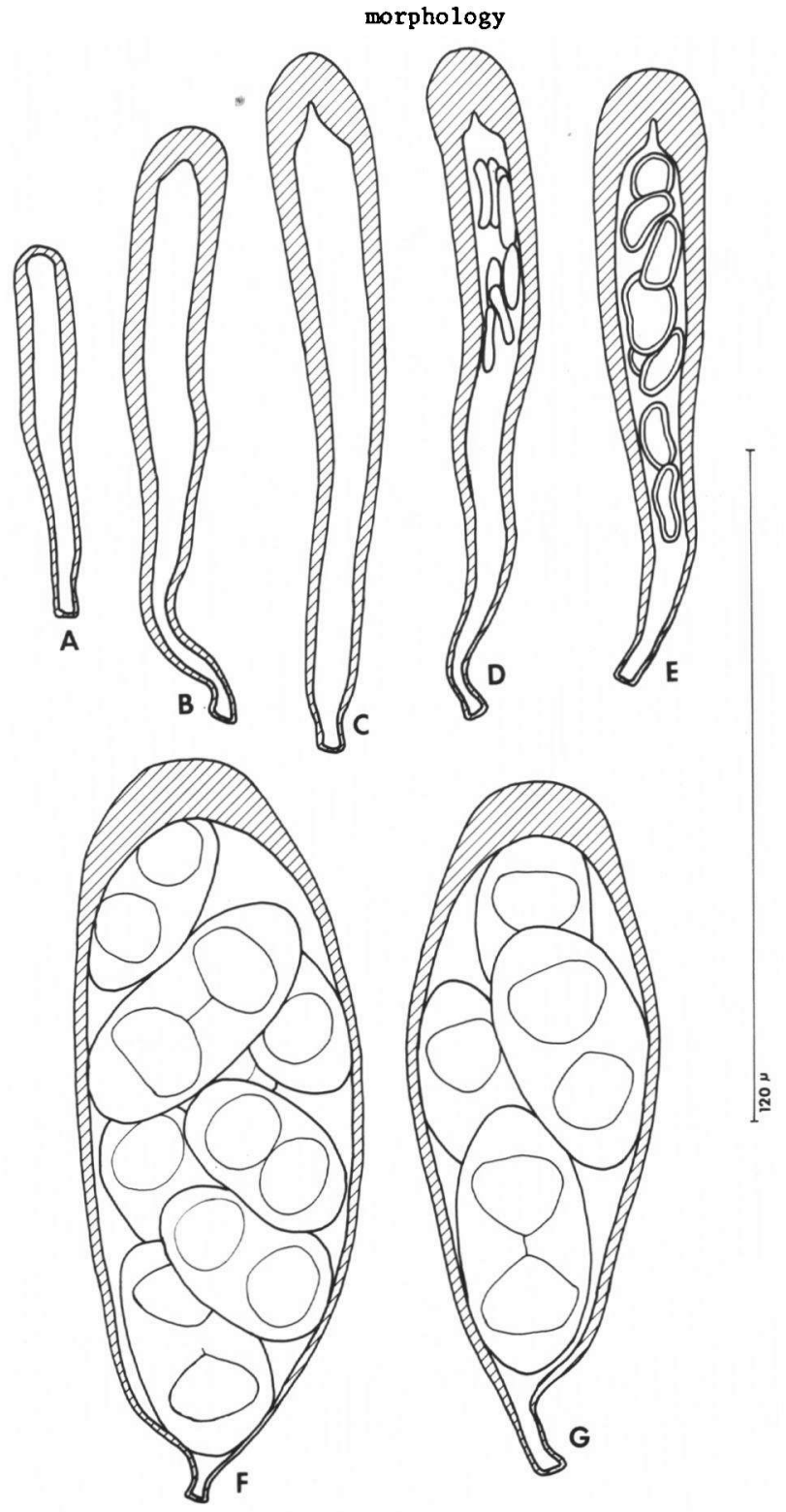

Figure 9. Development of ascus and spores in Megaloblastenia marginiflexa (Sipman 13035). A-B. young asci; C-E. asci without and with spore initials; F, G. asci with mature spores. 

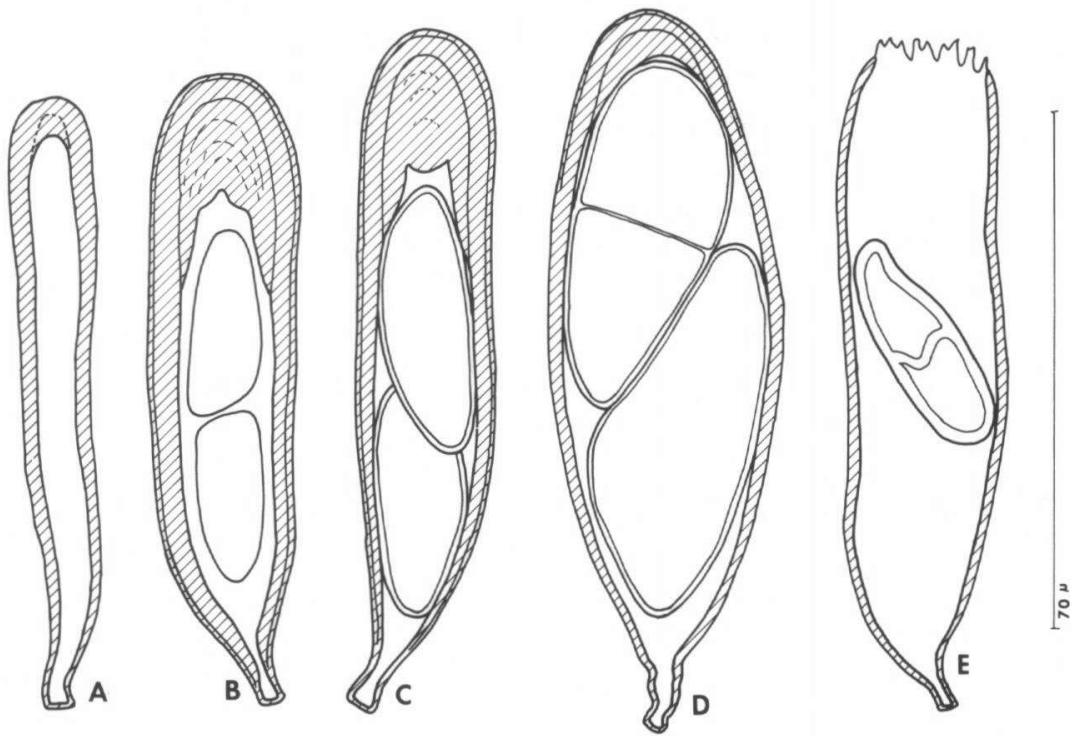

Figure 10. Development of ascus and spores in Catinaria versicolor (drawn after Sipman 11025, U). A. young ascus; B. ascus with spore initials; C, D. asci with young spores: $\mathrm{E}$. opened ascus with degenerate spore.

mature spores (P1. $21 \mathrm{~F}$ ). the wall shows a c. $0.8 \mu \mathrm{m}$ thick outer layer and a c. $1.6 \mathrm{\mu m}$ thick inner layer. In that stage the apical dome of the ascus is slightly less thick, but presents an ocular chamber. In old, degenerate spores the wall and the septum become much swollen, to c. $3 \mu \mathrm{m}$. Such spores can be observed occasionally inside the hypothecium. Another probable degeneration feature is the occurence of a laminar structure in the dome (Fig. $10 \mathrm{~B}, \mathrm{C}$ ) in asci with spore initials (cf. HONEGGER 1978). LECANIA SULPHUREOFUSCA, with spores resembling the atrorubicans-type (Fig. 11).

Here the development of ascus and spores follows largely the pattern of Megalospora gronulans. The following differences exist: 1. the dome is never very thick, to $6 \mu \mathrm{m} ; 2$. the septum formation starts with a lamel which divides the spore lumen, not with a ring along the wall. Afterwards the septum increases slightly in thickness and shows a small central pore.

The same stages as in Megalospora granulans and M. campylospora have been observed in all Megalospora species. Differences occur in the form of the spore 

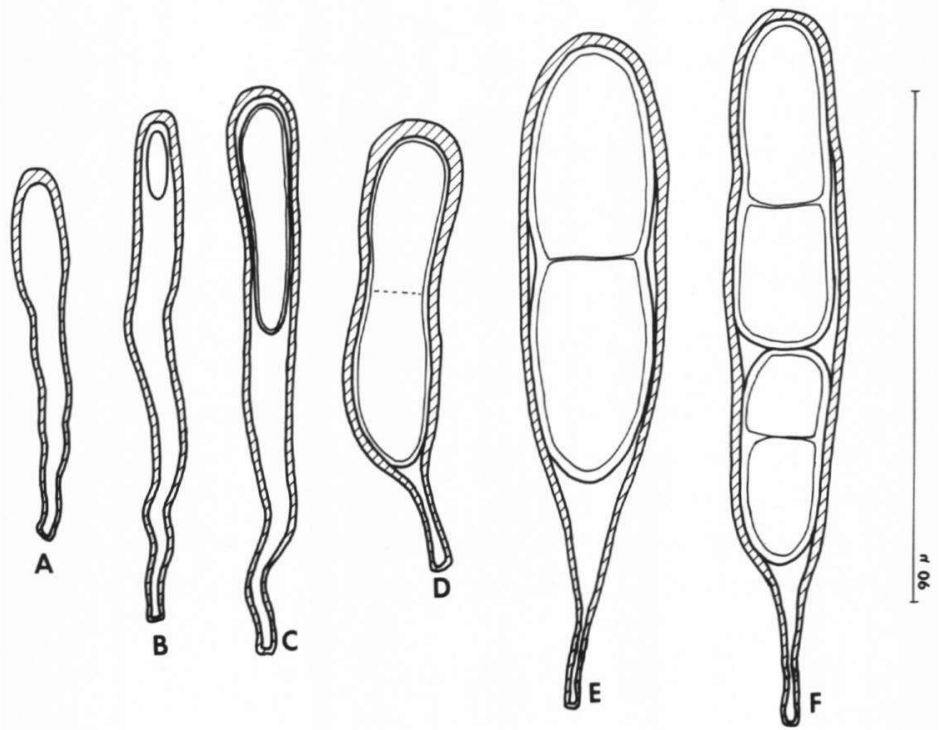

Figure 11. Development of asci and spores in Lecania sulphureofusca (drawn after Sipman $11901, U)$. A. young ascus; B. ascus with spore initial; C, D. asci with young spores; E. ascus with mature spore; F. abnormal ascus with two spores.

initials: these may be very elongate in species with tuberculosa-type spores. However, individual variation within species outreaches differences between species. In all investigated species a reduction of the spore number per ascus has taken place already when the spore walls become visible. In species with more than one spore per ascus subsequent further reduction in number may occur in any later stage. In species with a single spore per ascus only one initial is formed.

In the species with pluricellular spores the septa are formed simultaneously, not in a distinct sequence as in e.g. Graphidacede or The Lotremataceae. In species with tuberculosa- or coccodes-type spores the septum formation starts with thickened rings along the walls when the spore has attained nearly its full size and has a thick wall. These rings constrict simultaneously. In species with lopadioides-type spores the rings which initiate the septum formation are indistinct, if present at all. Both transverse and longitudinal septa develop simultaneously, but the transverse septa are slightly thicker in the beginning. 
Septation is present here already when the spores are at about half of their adult size. In the species with pupa-type spores the septa are formed after the spores have reached their adult size and a thick wall is present. The transverse septa start as thickened rings along the outer wall. These rings increase considerably in thickness and constrict the lumen but leave a wide central pore. After the increase of the transverse septa the longitudinal septa are formed. In Austroblastenia pauciseptata, with pauciseptata-type spores, no spore development could be studied yet.

\section{H. Pycnidium}

Limited use has been made thus far of pycnidia in lichen taxonomy, probably because they are often difficult to find. However, NYLANDER, e.g. (1867, p. 326) already made taxonomic use of them, and notably GLUECK (1899) and recently VOBIS (1980) have demonstrated that the pycnidia show many potentially useful variations. During the present study pycnidia have been found in several investigated species.

In Megalosporaceae, as well as in Catinaria versicolor, C. grossa and Cliostomon griffithii, the species in which they have been studied, the pycnidia are immersed and recognisable on the surface of the thallus as slightly raised, pigmented dots. They resemble much the primary corpuses of Megalosporaceae in appearance and in size, but are less frequent. The main diagnostic features have been found in the structure of the conidiophores.

In Catinaria versicolor ( $\mathrm{P} 1.24 \mathrm{~A}-\mathrm{C}$ ) the conidiophores are phialide-like: type II of VOBIS (1980), Peltigera-type of GLUECK (1899). They consist mainly of a single elongate conidiogenous cell which produces the pycnospores apically. These conidiogenous cells form a lining on the inner surface of the pycnidium, which is surrounded by a thin pseudoparenchymatous layer. This type of conidiophores has also been found in Catinoria grossa and Cliostomom griffithii.

In Megalosporaceae (P1. 22, 23) the conidiophores are of the bayonet-type: type VI of VOBIS (1980), Parmelia-type of GLUECK (1899). They consist of more or less branched, up to c. $30 \mu \mathrm{m}$ long filaments which are composed of about five elongate cells measuring c. $5 \times 3 \mu \mathrm{m}$. All of these cells are conidiogenous and produce pycnospores on top of a small terminolateral process which is c. 2 um long and $0.5 \mu$ mide. This type has been recorded for e.g. Catizlaria (KILIAS 1981, p. 273) and many Physciaceae (VOBIS 1980).

No differences have been found among the pycnospores of the investigated species. They measure c. $5 \times 0.7 \mu \mathrm{m}$ in size and are more or less rod-shaped to 
clavate. In Megatospora they seem to function as spermatia (cf. p. 35) but the term pycnospores has been maintained in the descriptions for them, as a neutral indication without speculation about their function.

The ontogeny of the pycnidia has not been studied. VOBIS (1980) found that it is largely correlated with the conidiophore type, and thus it can be expected that in Catinaria versicolor the ontogeny follows the Lecanactis-type and in Megalosporaceae the Umbilicaria-type.

\section{Chemistry}

Four thallus substances have been demonstrated by TLC: zeorin, usnic acid, pannarin and lichexanthone (Fig. 12). In old herbarium specimens a weft of fine needles was sometimes present over the thallus which might represent zeorin. They cover the thallus and obscure e.g. soralia. The presence of usnic acid can usually be established macroscopically by the yellowish tinge of the thallus, and the presence of lichexanthone is easily demonstrable by its orange fluorescence in long-wave UV-light. Usnic acid was sometimes present in low concentrations, e.g. in specimens of Megazospora atrombicans ssp. sendaiensis, $M$. sulphurata and $M$. tuberculosa and in a few South American specimens of $M$. tuberculosa only zeorin could be demonstrated with certainty.

In the apothecia five additional substances have been found with some constancy. None of them could be identified so $\mathrm{far}$, and they are referred to as unknown substances A-E (Fig. 12):

Substance A is found in Rf class 4 with solvent system A. In short-wave UV-light it produces a yellowish fluorescence with a greenish tinge. After sulphuric acid treatment the spots change to grey-brown, often with an olivaceous tinge. On some plates several spots with the same properties but slightly different Rfvalues have been observed. They usually did not appear again upon a repeat nor did they become more separate with solvent system B. Probably they reflect irregularities in the TLC-process. Upon KOH-treatment the spots produce a weak reddish colour.

Substance $B$ is found in Rf class 3 with solvent system A. In short-wave UV-1ight it shows up clearly, and in long-wave UV-light it produces an orange fluorescence. After sulphuric acid treatment its spots change to brown. As in substance A occasionally several spots have been found with the same properties but slightly different Rf-values, which are supposed to be due to irregularities. The Kreaction of the spot is yellow.

The yellow $\mathrm{K}$-reaction of the excipulum does not always coincide with the presence of substance B: in Megazospora maderensis the $\mathrm{K}$-reaction of the excipulum 


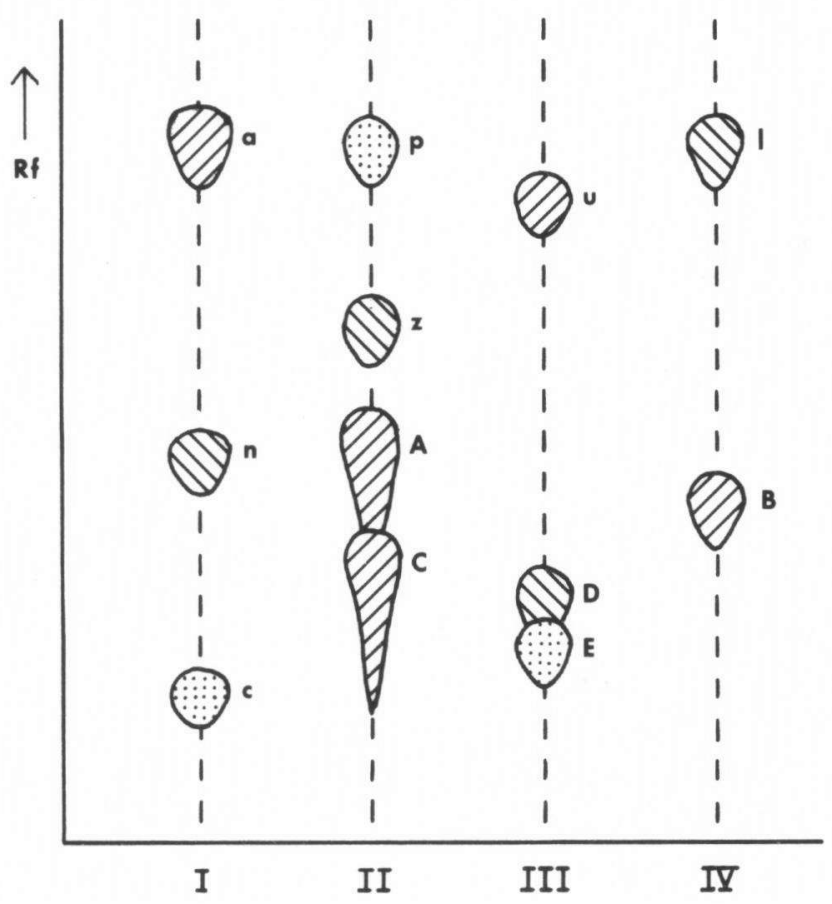

Figure 12. TLC-spots of the Megalosporaceae, schematically. I. standard (Cladonia symphycarpa); II-IV. spots of the Megalosporaceas. a = atranorin, $\mathrm{n}$ = norstictic acid, $\mathrm{c}$ - connorstictic acid, A-E = unknown substances of the apothecia, $1, p, u, z=$ thallus substances: $1=1$ ichexanthone, $p=$ parietin, $u=$ usnic acid, $z$ = zeorin.

is yellow, but only substances $A$ and $C$ have been found; in Austroblastenia pauciseptata the K-reaction is negative, but the ILC-spots of substance B are clearly present.

Substance $C$ has the same properties as substance $A$, but in solvent system $A$ its spots belong to Rf class 3, slightly below substance $B$. As in substance $A$ and $B$, the spots of substance $C$ may show some variation in Rf-value. 
Substance D is found in Rf class 3 with solvent system A, slightly below substance C. In short-wave UV-1ight it shows up, and in long-wave UV-1ight it produces a red fluorescence. With sulphuric acid treatment no staining occurs. The K-reaction is red.

Substance $E$ is found in Rf class 3 with solvent system A, slightly below substance D. In short-wave UV-light it does not show up, in long-wave UV-light it produces a bluish-white fluorescence. With sulphuric acid treatment no staining occurs. Its K-reaction is negative.

Substances $A$ and $C$ are usually found together, but in varying proportions. In some species constantly one of them is dominant, in others both may do so. Substance $B$ occurs in some species together with $A$ and $C$, and in variable amounts, in other species it occurs alone. Substances $D$ and $E$ appear to occur always together, and records of specimens with only one of them can be explained as missings due to low concentrations. They are always accompanied by substances $\mathrm{C}$ and/or A, and have been found mostly in Megalospora gompholoma and $M$. campy Zospora.

Regularly additional spots have been observed by TLC, which have not heen used here because they are so weak that they are hardly detectable, or because they show up rather clearly on some TLC-plates but not on others. Thus no proof of their presence or absence can be given. Some of them might become useful with improved TLC techniques. Therefore the two most frequent ones are mentioned here: 1. spots with the same properties as zeorin have been observed regularly between the spots of usnic acid and zeorin; 2. a spot with the same properties as substance $B$ has been found several times in Rf class 2, below the level of substance $\mathrm{E}$.

Amyloid substances have been demonstrated by staining with I-solution. They have been found only in the asci and the hymenial gelatine.

In the epithecium and the excipulum the following pigments and granular substances which do not dissolve in acetone, have been found: Crystals of calcium oxalate. These are frequent in the medullary excipulum of many species, and have also been found in the upper part of the ectal excipulum of Megalospora coccodes ssp. nigricans and in the epithecium of one specimen of this subspecies ( $\mathrm{P} 1.6 \mathrm{~B}$ ).

Diffuse epithecium pigments. Most frequent in Megalosporaceae is an orange-brown pigment. Its colour changes into a greyish brown in K-solution. In deteriorated apothecia its colour may have changed into an indifferent brown. The second most frequent pigment has an olivaceous colour, which may vary from greenish black to 
olivaceous brown and appears to change easily into a brown tinge. Sometimes even within a single apothecium some parts of the epithecium may have an olivaceous colour whereas other parts are darkbrown or brown. In Megalospora weberi the epithecium has a bluish-green colour, which changes in deteriorating apothecia into olivaceous or even brown. It is unclear whether this concerns the same olivaceous pigment or not.

Granular deposits on the epithecium (epipsamma). These do occur in all species with pruinose discs, and are in all likelyhood responsable for the pruinose appearance. The granules are usually c. 1-2 um wide, but of ten form aggregates of

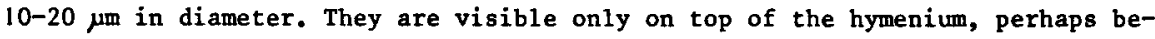
cause they become invisible within the hymenial gelatine. In K-solution and in lactophenol-cotton blue preparations they disappear. The external appearance of the pruina, especially the colour, suggests that there are several types of granular deposits on the hymenium, but no clear chemical differences have been found.

Crystalline inclusions in the epithecium. Besides crystals of calcium oxalate, found in a single specimen of Megalospora coccodes ssp. nigmicans as mentioned above, in $M$. knightii and $M$. mezanodermia concentrations of c. $2 \times 1 \mu \mathrm{m}$ large, colourless crystals have been found in the epithecium, which penetrate in tongues of up to $70 \mu$ m long into the hymenium. They do not change in the process of preparation used, and their nature is uncertain. In $M$. knightii they give a yellow colour upon application of $\mathrm{K}$-solution.

Greenish granules, which turn reddish in K-solution, have been found in the epithecium and the upper part of the excipulum of many specimens of the species with an olivaceous epithecium. Their presence or absence and density are very variable, therefore they have not been mentioned in the descriptions. Perhaps they are caused by some bacterial infection.

Yellowish crystalline substances in the upper part of the ectal excipulum. These occur in Megalospora australiensis, M. coccodes ssp. coccodes, M. granulans, $M$. pachycheila and $M$. sulphureomfa. They are difficult to observe or to define because of the small size of their crystals, which are densily aggregated. Probably they belong to various substances.

Brown or black-brown substances in the excipulum. These are generally concentrated in the ectal excipulum and the subhypothecium. They do not dissolve in acetone, nor do they show a colour change upon application of $\mathrm{K}$-solution. Usually they cover the hyphae, but in the ectal excipulum they appear to be sometimes concentrated in the matrix between the hyphae. 
An orange-brown pigment is sometimes present in a thin layer in the subhypothecium. It disappears with acetone washing of sections, but it has not been found as a separate spot on the chromatograms. Perhaps it concerns high concentrations of substances $A$ or $C$.

"Oil droplets" in the hymenium. They occur in all species of Austroblastenia and Megalospora (P1. 5 D). Their form is described on p. 24. Their true nature is unknown, and their name is given only because they show a superficial resemblance with oil droplets. They disappear in acid solutions, e.g. 1actophenol-cotton blue, diluted sulphuric acid and lactic acid, but do not dissolve in acetone or ethanol. Rather similar droplets occur in the hymenium of Lecania sulphureofusca. 


\section{chapter 5. DISCUSSION OF THE TAXONOMICAL CONCLUSIONS}

\section{A. Delimitation of the family and the genera}

From the observations made for the present study it has become clear that the genus Megalospora, as defined by ZAHLBRUCKNER (1927), contains six distinct groups (cf. table 1 on p. 62-63), group I - VI:

I. Megalospora sulphurata and related lichens. This group includes the majority of the species in Megalospora sensu ZAHLBRUCKNER, and is distinguished by a combination of distinctive and unusual characters: 1. the thallus contains zeorin with either pannarin or usnic acid; 2 . the hymenium contains numerous oil droplets; 3. the hymenium is generally over $140 \mathrm{~m}$ high; 4 . the hymenium reacts usually in a special way with I-solution: the asci and the lowest zone of the hymenium stain more or less intensely blue, the remaining parts remain largely

unstained; 5. the apothecia of most species contain special substances not found in the thallus, viz. unknown substances A - E; 6. the spores are very large, usually over $40 \mu \mathrm{m}$ long and $25 \mu \mathrm{m}$ wide, and are bicellular. This group is also homogenous with respect to ascus type, conidiophore type and ontogenetical characters. The spores, though always bicellular, belong to two distinct types, the sulphurata- and the atrorubicans-type (p. 44).

II. "Megalospora dimota". This species, in the present study treated as Megaloblastenia marginiflexa, resembles group I in most respects but has a few significant differences: 1. the spores are small and belong to the albidulatype (p. 46); 2. the hymenium lacks oil droplets; 3 . the hymenium becomes strongly and uniformly stained blue with I-solution.

III. "Megalospora jomaicensis". The correct name for this species is Lecania sulphureofusea, cf. p. 179. It differs from group I by the following points: 1. the thallus contains additional substances besides zeorin and usnic acid; 2. a thalloid amphithecium is present; 3. the hymenium is up to $120 \mu \mathrm{m}$ high; 4. the primary corpus stage is not persistent; 5 . the hymenium becomes uniformly stained blue with I-solution. Significant features which group III shares with group $I$ are, besides the large, bicellular spores, the cortex type (megalospora-type, cf. p. 20) and the presence of oil-droplets in the hymenium. The form of the conidiophores and the ascogonia is unknown.

IV. "Megalospora" versicolor and "Megalospora" isidiza (published after ZAHLBRUCKNER). The following important differences with group $I$ are present: 1 . the cortex is of the Catinaria versicolor-type (cf. p. 20); 2 . the thallus con- 
tains zeorin with atranorin, as far as substances are demonstrable; 3 . the hymenium lacks oil droplets; 4, the hymenium becomes stained uniformly blue with I-solution; 5. the conidiophores are of the phialide-type (p. 54); 6. the primary corpus stage is not persistent. Apart from the large, bicellular spores which resemble the atrorubicans-type (p. 44) but are mostly present with two in each ascus, this group shares with group I only features which are comon in the order Lecanorales. In contrast it agrees with Catinaria grossa in the features mentioned above, at least point 3,4 and 5 .

v. "Megalospora" premneelza. This species was placed by SANTESSON (1952) in a separate genus as Porotheciopsis premeella. Except for the peculiar paraplectenchymatous cortex, this species agrees with group IV in all characters as far as they are mentioned by SANTESSON (1.c.).

VI. "Megalospora" biclipea and a number of comparable species. This group comprises the species treated on p. 177, which were included in Megalospora by ZAKLBRUCKNER but defy his own definition of the genus because they have smaller spores, up to 28 um long. Otherwise they resemble group IV rather than group I, in as far as their characters are known.

The characters which serve to distinguish group I and II from group III - VI are shared by a considerable number of species thus far included in Bombyliospora, Blastenia, Lecidea and Lopadizm and a few undescribed species. They are mentioned here in four groups, VII - X:

vII. "Bombyliospora" tuberculosa and nearly all other Bombyliospora species without anthraquinones agree with group $I$ in all mentioned points except for the spores, which belong to the tuberculosa- and coccodes-type (p. 44). $B$. pachycheila moreover differs by the presence of lichexanthone instead of usnic acid or pannarin.

vIII. "Blastenia endochromoides" and "Lecidea" flavidoatra. These species agree with group II in all mentioned respects.

IX. "Lopadium" pauciseptatum and a new species, here described as Austroblastenia pupa (cf. p. 85). They agree with group $I$ in all mentioned respects except for the spores, which possess thick septa and belong to the pauciseptata- or pupa-type (p. 46). In spore size, spore number per ascus and hymenium height they approach group II.

$x$. Three species with muriform spores, published in the present study as Megalospora kalbii, M. Zopadioides and M. queenslandica. They agree with group $I$ in all mentioned respects except for the spores, which are muriform with thin 


\begin{tabular}{|c|c|c|}
\hline $\begin{array}{l}\text { TABLE } 1 \\
\text { principal groups of species } \\
\text { in MEGALOSPORA } \\
\text { sensu ZAHLBRUCKNER }\end{array}$ & 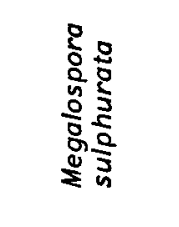 & 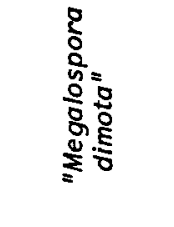 \\
\hline Group nr. (cf. p. 60-61): & I & II \\
\hline Thallus: cortex type (cf. p. 20) & megalospora & megalospora \\
\hline chemistry & $\begin{array}{l}\text { zeorintusn. } \\
\text { zeorin+pan. }\end{array}$ & zeorintpan. \\
\hline Apothecium: thalloid amphithecium & - & - \\
\hline oil droplets in hymenium & + & - \\
\hline hymenium height $(\mu \mathrm{m})$ & $140-300$ & $110-180$ \\
\hline I-reaction of hymenium & \pm & + \\
\hline chemistry & $\begin{array}{l}\mathrm{AC} \\
\mathrm{ABC} \\
\mathrm{ACDE} \\
-\end{array}$ & B \\
\hline Spore: number per ascus & $1,2-8$ & $3-8$ \\
\hline size, length $(\mu \mathrm{m})$ & $(30-) 40-170$ & $20-45$ \\
\hline width ( $\mathrm{mm})$ & $25-40$ & $10-20$ \\
\hline thick septa & - & + \\
\hline Pycnidium: conidiophore type (cf. p. 54) & bayonet & bayonet \\
\hline Ontogeny: persistent primary corpus & + & + \\
\hline straight ascogonia & + & + \\
\hline
\end{tabular}




\begin{tabular}{|c|c|c|c|}
\hline 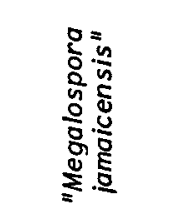 & 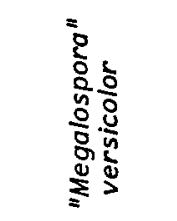 & 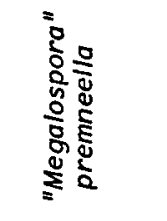 & 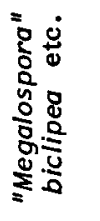 \\
\hline III & IV & v & VI \\
\hline megalospora & catinaria & paraplect. & $?$ \\
\hline $\begin{array}{l}\text { zeorin }+ \\
\text { usnic ac.+ } \\
\text { unkn. }\end{array}$ & $\begin{array}{l}\text { zeorin } \\
+ \text { atranor. }\end{array}$ & $?$ & $?$ \\
\hline+ & - & - & - \\
\hline+ & - & - & - \\
\hline $85-100$ & $100-160$ & $70-120$ & $60-140$ \\
\hline+ & + & + & + \\
\hline - & - & $?$ & $?$ \\
\hline 1 & $(1-) 2$ & 1 & 8 \\
\hline $70-75$ & $40-65$ & $38-68$ & $14-28$ \\
\hline c. 25 & $15-22$ & $18-28$ & $5-14$ \\
\hline- & - & - & - \\
\hline$?$ & phialide & $?$ & $?$ \\
\hline - & - & $?$ & $?$ \\
\hline$?$ & $?$ & $?$ & $?$ \\
\hline
\end{tabular}


septa and belong to the lopadioides-type (p. 46).

These observations show that the genus Megalospora in ZAHLBRUCKNER's (1927) sense consists of several unrelated groups which are better placed in different genera. Therefore the following arrangement is proposed here:

$=$ Groups I, II, VII, VIII, IX and $X$ are united in the family Megalosporaceae, characterised by the following combination of characters:

1. cortex of Megalospora-type;

2. thallus containing zeorin with usnic acid or pannarin or lichexanthone;

3. conidiophores of bayonet-type (p. 54) in the pycnidia;

4. persistent primary corpus stage;

5. occurrence of apothecium substances $A-E$. Also the ascus type seems to be characteristic for this family (HAFELLNER \& BELLEMERE 1982).

Within this family three genera have been distinguished:

Megalospora, composed of groups $\mathrm{I}, \mathrm{VII}$ and $\mathrm{X}$, and characterised by:

1. large, bicellular or pluricellular spores with thin septa (sulphurata-, atrorubicans-, tuberculosa-, coccodes- or lopadioides-type);

2. hymenium containing oil droplets;

3. occurence of apothecium substances A - E.

Megazospora pachycheiza, the only species in the family with lichexanthone, belongs here.

Austroblastenia gen. nov. (description on p. 82 ), composed of group IX, and characterised by:

1. pluricellular spores with thick septa but without thick apical sporewalls (pauciseptata- or pupa-type);

2. hymenium containing oil droplets;

3. occurrence of apothecium substance $B$ only. Megatoblastenia gen. nov. (description on p. 87), composed of groups II and VII, and characterised by:

1. spores with thick septa and apical walls (albidula-type);

2. hymenium without oil droplets;

3. occurrence of apothecium substances $A$ - E.

This genus is the only one which lacks oil droplets in the hymenium, the character by which the family is otherwise easy to recognise. 
= Groups II - VI are excluded from the genus Megalospora and the family MegaLosporaceae, and placed in the genus Catinaria (family Lecideaceae) or left without new arrangement.

The division of the Megalosporaceae into three genera is in accordance with the three most distinct phylogenetical lines cf. p. 203. A consequence is the reduction into synonymy of Bombyliospora, because its type species, $B$. tuberculosa, belongs in Megalospora. The fusion of these two genera has already been proposed by HAFELLNER \& BELLEMERE (1982).

A separate family Megalosporaceae was already proposed provisionally by VEZDA (1974) and validated by HAFELLNER \& BELLEMERE (1982). But the family as defined by VEZDA is heterogenous in the present author's opinion because it includes on one hand Megalospora and on the other hand Catinaria and Psorotheciopsis. These two genera are so distinct from Megalospora, as shown above, that in the author's opinion they cannot belong in the same family. Therefore Catinaria and Psorotheciopsis are considered to belong in the Lecideaceae because they show less differences with other Lecideaceae than do the Megalosporaceae. The characters by which Catinaria and Psorotheciopsis differ from other Lecideaceae, are: 1. occurence of large, bicellular spores; 2 . occurence of pored septa. Megalosporaceae differ moreover by: 3. presence of a persistent primary corpus stage; 4, occurence of substances A - E in the apothecia; and 5. occurrence of oil droplets in the hymenium.

Moreover, VEZDA's characters for the delimitation of the Megalosporaceae seem to be not very reliable: 1. Pored septa are often absent in "Bombyliospora"-species, e.g. in Megalospora tuberoulosa. Moreover pored septa seem to be not characteristic because they are not uncommon in other 1 ichen groups, such as the family Teloschistaceae. Unclear is whether it concerns real pores in Megalosporaceae or merely thin parts of the septa (pseudopores), as occur frequently in the Physciaceae (POELT \& MAYRHOFER 1979). TEM investigations seem required to determine whether the structure of the pored septa is uniform in the groups indicated by VEZDA. 2. Apothecia of the structure as in Megalosporaceae seem to be not characteristic, because they occur also in e.g. Bacidia, Brigantiaea and Letrouitia (e.g. B. fuscolutea, L. domingensis). Since these species, like Megalospora, have large spores, the resemblance in apothecium structure could be explained by the assumption that it concerns an adaptation to the dispersal of large spores. Such convergences in functional structures are considered to be very frequent in fungi (SAVILLE 1968). 
According to HAFELLNER \& BELLEMERE (1982) the ascus type, defined by ultrastructural features, is the most distinct feature of the family Megalosporaceae. In the present author's opinion, however, more TEM investigations are required, also in representatives of the family Lecideaceae, for a proper evaluation of the significance of this character for the distinction of the Megalosporaceae.

\section{B. Systematic position of the Megalosporaceae}

Determination of the systematic position of the Megalosporaceae is difficult due to the fact that several of the characters used in this study are very incompletely investigated in other lichen taxa (cf. table 2 on p. 68-69). Notably for those crustose Lecanorales among which the relatives of the Megalosporaceae are most likely to be found, little information is available concerning the ontogeny of the apothecium, the ascus type, the conidiophore type in the pycnidium, and the thallus - and apothecium chemistry. This causes many uncertainties in a comparison of their characters. Another consequence of this lack of knowledge is that the genera described in these groups might, like Megalospora sensu ZAHLBRUCKNER, be heterogenous. This has been demonstrated al ready for e.g. Lecidea (cf. HERTEL 1967, 1977) and Catillaria (KILIAS 1981). The heterogenous groups have to be revised before they offer reliable entities for comparison.

Therefore this discussion of the systematic position of the Megalosporaceae has been confined to groups that have been suggested in the literature as possible relatives. The principal source of such suggestions is the position in ZAHLBRUCKNER's (1926) system of the groups united here in the Megalosporaceae. ZAHLBRUCKNER placed the genus Megalospora in the Lecideaceae and Bombyliospora in the Teloschistaceae, both belonging to the order Lecanorales.

The attribution of the Megalosporaceae to the order Lecanorales seems well established by the ontogeny and structure of its ascocarps, which are true apothecia with parathecium and paraphyses, and fit well the pattern described for this order by HENSSEN \& JAHNS (1973).

The Lecideaceae as defined by ZAHLBRUCKNER (1926) are based on absence rather than presence of distinguishing characters. Thus there exist no strong reasons to exclude the Megalosporaceae. But as inferred above (p. 65) it is unlikely that the Megalosporaceae belong in the same family with Catinaria versicolor and the genus Psorotheciopsis, which are more closely related to the other Lecideaceae.

The Teloschistaceae have been redefined recently to consist only of species with Teloschistes-type asci (POELT \& HAFELLNER 1980). This forms a constant dif- 
ference with the Megalosporaceae, which have Lecanora-type asci (cf. p. 44).

A further suggestion for the relationship of the Megalosporaceae has been found in POELT's (1974) definition of the suborder Buelziineae, which mentions: \pm clavate, I+ blue asci; usually bicellular spores, often thick-walled and with complex wall structure; short-celled fulcra and short, straight conidia. These same characters are more or less clearly present in the Megazosporaceae. POELT includes in this suborder the families Candelariaceae, Physciaceae and Teloschistaceae. The Condelariaceae have generally unicellular, thin-walled spores and are thus very different from the Megalosporaceae. Therefore a closer comparison of the Megalosporaceae with the Physciaceae and the TeZoschistaceae has been made. Fortunately both families have received much recent attention, e.g. by HAFELLNER, MAYRHOFER \& POELT (1979) (asci and spores in the Physciaceae), HAFELLNER \& POELT (1979) (asci and spores in the Teloschistaceae), vOBIS (1980) (pycnidia in both families), HENSSEN \& JAHNS (1973) (ontogeny of the ascocarps), SANTESSON (1970) (chemistry of Caloplaca).

The most important.characters of the Physciaceae appear to be in the spore shape and development and in the ascus structure. The spores differ from those of the Megalosporaceae by the invariable presence of dark pigment and the septum formation, which starts with a thin lamella which divides the spore lumen before the formation of further thickenings. The ascus structure of most Physciaceae differs by the presence of a sharply delimited tholus. Only the genera Epilichen and Catolechia show more resemblance with Megalosporaceae because they have a tholus which runs down along the ascus wall. However, they differ by the presence of a more intensely staining apical part in the tholus, and some doubt has been expressed to their attribution to the Physciaceae (HAFELLNER, MAYRHOFER \& POELT 1979). The pycnidia in Physciaceae contain conidiophores of type $V$ to VII (VOBIS 1980), thus are pluricellular with conidium formation on terminolateral processes on the intercalary and terminal cells. Similar conidiophores are found in the Megalosporaceae. Ascocarp ontogeny shows a considerable variation within the Physciaceae, thus is of little use for an estimation of the relationship. Chemically the Physciaceae differ from the Megalosporaceae by the absence of pannarin and the unknown substances of the excipulum, and by the rarity of usnic acid.

In the Teloschistaceae spore formation and structure agree more closely with Megalosporaceae, viz. by the presence of colourless spores and by the septum formation which starts with a thickened ring along the outer spore wall. Polar thickenings, however, seem to be unrecorded in this family. The ascus structure 
TABLE 2

comparison of MECALOSPORACEA with supposed relatives

\begin{tabular}{|c|c|}
\hline 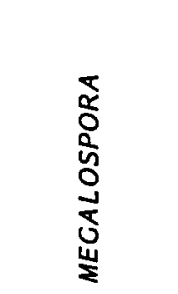 & 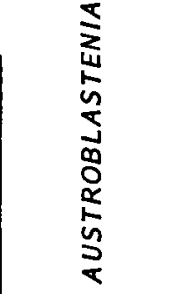 \\
\hline megalospora & megalospora \\
\hline $\begin{array}{l}\text { zeorin+usn. } \\
\text { zeorin+pan. } \\
\text { zeorin+1ic. }\end{array}$ & zeorintpan. \\
\hline- & - \\
\hline+ & + \\
\hline $105-300$ & $120-250$ \\
\hline- & - \\
\hline lecanora & lecanora \\
\hline \pm & \pm \\
\hline $\begin{array}{c}\mathrm{AC} \\
\mathrm{ABC} \\
\mathrm{ACDE} \\
\text { B } \\
-\end{array}$ & B \\
\hline $1,2-8$ & $4-8$ \\
\hline $2-12(-\infty)$ & $4-\infty$ \\
\hline $30-200$ & $35-80$ \\
\hline $20-40$ & $14-32$ \\
\hline- & + \\
\hline - & - \\
\hline \pm & + \\
\hline bayonet & bayonet \\
\hline+ & + \\
\hline+ & + \\
\hline
\end{tabular}

Apothecium: thalloid amphithecium oil droplets in hymenium hymenium height ( $ر$ m) strongly thickened paraphyse tips ascus type (cf. p. 44) I-reaction of hymenium chemistry

Spore: number per ascus number of cells size, length ( $\mathrm{mm}$ ) width ( $\mathrm{m})$

thick septa

dark-pigmented pored septa

Pycnidium: conidiophore type (cf. p. 54)

Ontogeny: persistent primary corpus straight ascogonia 


\begin{tabular}{|c|c|c|c|c|c|}
\hline 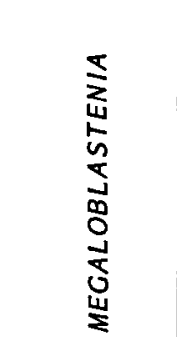 & 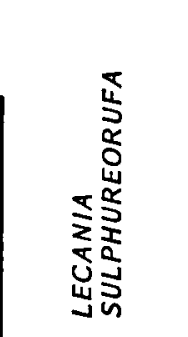 & $\begin{array}{l}\frac{\Sigma}{\alpha} \\
\frac{\alpha}{k} \\
\frac{\Sigma}{\delta}\end{array}$ & axonomy etc. & 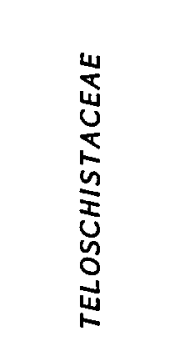 & 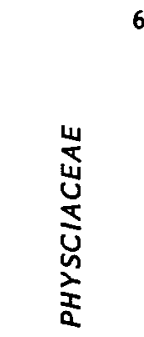 \\
\hline megalospora & megalospora & catinaria & $?$ & various & various \\
\hline $\begin{array}{l}\text { zeorin+usa. } \\
\text { zeorin+pan. }\end{array}$ & $\begin{array}{c}\text { zeorin }+ \\
\text { unkn. } \\
\text { usnic }\end{array}$ & $\begin{array}{c}\text { zeorin }+ \\
\text { atranor. }\end{array}$ & - & $\begin{array}{l}\text { various, } \\
\text { mainly } \\
\text { anthraquin., } \\
\text { no pannar. }\end{array}$ & $\begin{array}{l}\text { various, } \\
\text { often } \\
\text { zeorin }+ \\
\text { atranor. }\end{array}$ \\
\hline- & + & - & - & \pm & \pm \\
\hline- & + & - & - & - & - \\
\hline $110-180$ & $85-100$ & $60-160$ & $30-60(-70)$ & $\leqslant 100$ & $\leqslant 100$ \\
\hline- & - & \pm & + & + & + \\
\hline lecanora & lecanora & 1ecanora & lecanora & teloschist. & lecanora \\
\hline+ & + & + & + & + & + \\
\hline $\begin{array}{c}\text { ACDE } \\
\text { B }\end{array}$ & - & - & - & - & - \\
\hline $3-8$ & 1 & $(1-) 8$ & 8 & $(4-) 8(-\infty)$ & 8 \\
\hline 2 & 2 & 2 & 2 & $(1-) 2(-4)$ & $(1-) 2(-4)$ \\
\hline $20-45$ & $70-75$ & $14-28(-70)$ & $7-16$ & $\leqslant 35$ & $\leqslant 60$ \\
\hline $10-20$ & c. 25 & $5-18(-28)$ & $2-7$ & Sc. 15 & $\leqslant c .25$ \\
\hline+ & - & - & - & + & + \\
\hline - & - & - & - & - & + \\
\hline+ & + & \pm & - & + & \pm \\
\hline bayonet & $?$ & phialide & bayonet & teloschist. & $\begin{array}{r}\text { bayonet } \\
\left(a_{.0 .}\right)\end{array}$ \\
\hline+ & - & $-/ ?$ & - & $?$ & $?$ \\
\hline+ & $?$ & $?$ & $?$ & $?$ & $?$ \\
\hline
\end{tabular}

table 2 , continued 
is very uniform, with a "bell-shaped" tholus, unlike in the Megalosporaceae. Probably in relation with these different ascus types, there is also a difference in the distance between the ascus apex and the epithecium surface. In Teloschistaceae it appears to be larger, about 20-30\% of the hymenium height, as has been measured in specimens of Caloplaca cerina, $C$. aurantiaca, C. fermuginea and c. quadrilocularis. In Megalosporaceae it is about 10-15\%. The conidiophores in the pycnidia of the Teloschistaceae are of type VIII or a transition form between VII and VIII (VOBIS 1980), and thus provide another difference with the Megalosporaceae. The apothecium ontogeny seems to offer no special characteristics unshared by e.g. Leconoraceae or Lecideaceae, thus gives no further informations as to taxonomic relationships. Chemically the Teloschistaceae differ because they lack pannarin and the apothecium substances $A-E$, and rarely contain usnic acid, but on the contrary usually possess anthraquinones.

Summarising it appears that the Megalosporaceae have certain characters in common with both the Physciaceae and the Teloschistaceae, but there are also clear differences. Thus a position as a separate family in the Buelliineae seems indicative.

\section{Delimitation of species and infraspecific taxa}

Species delimitation is a much-discussed problem in lichen taxonomy, and in view of the limited number of available characters in these lower plants problematical distinctions will probably always remain. A useful discussion of the problem is given by e.g. KAERNEFELT (1979) who deals with the modern points of view. In the present author's opinion the "biological species" concept, which is based on the presence of genetical isolation, is preferable in all classifications because it has the strongest predictive value (see e.g. STACE 1980). The genetical isolation makes probable that such species are homogenous not only for the characters used in the preparation of the classification, but also for other, as yet uninvestigated, characters. As KAERNEFELT (1979) indicates, a pure "biological species" concept cannot be applied to lichen taxonomy at present, because the necessary experiments to demonstrate the genetical isolation cannot be performed. However, biological species can be approximated by tracing the effects of the genetical isolation, viz. the presence of differences. The more differences exist, the more likely it is that a biological species is at hand. Therefore in the present monograph the procedure of GRADSTEIN (1975, p. 35) has been followed, to recognise only species which possess two or more independent differentiating characters. No species rank has been attributed to groups of 
individuals which are characterised by only a single difference such as in chemistry ("chemospecies"), presence of vegetative propagules ("secundary species") etc, unless they are supported by additional evidence. Single differences, even when a genetical background for them is certain, might well reflect infraspecific variation, e.g. when depending on the occurrence of a different allele. Taxa based on infraspecific variation are generally less usefull because they are not likely to be more homogenous than the species to which they belong, except for the character on which they are based. Distinction of such taxa gives thus little new information, and to save on nomenclatural complications and identification problems it will often be better not to give them a formal taxonomic rank. This policy to require at least two differentiating characters for a species involves a risc for lumping good species. But in view of the present state of poor knowledge of most crustose lichen groups, that risc seems preferable over getting into unnecessary complication.

Where only a single constant and independent character is available, and the taxon furthermore has a geographical range separated from that of its nearest relative, it is treated here as a subspecies, because the allopatric distribution suggests a genetical isolation. The rank of variety has been used for important groups of plants which deviate in a single character from their nearest relative and have a largely, but not completely different range.

As an illustration of the above procedure the taxonomy of Megalospora sulphurata and $M$. tuberculosa is discussed.

Megalospora sulphurata is a pantropical species. Corresponding with its wide distribution it is variable, cf. p. 129. The specimens from Java have generally very dark apothecia, those from the Philippines have often pale apothecial margins and the Hawaiian specimens have generally very large spores. This geographical variation indicates that genetical differences exist among the populations of different areas, but the absence of discriminative characters prohibits distinguishing of more than one species. On Java, New Guinea, the Hawaiian Islands and Japan isidiate specimens have been found which have the apothecium characters of Megalospora sulphurata. Following the concept of "secondary species" (cf. POELT 1974) recognition of an isidiate secondary species could be considered. The apothecium characters of these plants, however, correspond with the local geographical variant of the "parent species", which indicates that they are derived from the local populations of Megalospora sulphurata. Thus, recognition of a single isidiate species is not acceptable because such a species would be polyphyletic and without any apparent interchange of genetical information. Recognition of four separate isidiate species is unpractical because 
no key characters are available. The same reasoning holds for the sorediate populations in Megalospora eulphurata.

Megalospora tuberoulosa is another widely distributed species. Specimens from Japan and China deviate markedly by the occurence of pannarin and by the frequent presence of pruinose apothecia (cf. p.163). Thus there is only a single constant differentiating character, and the specimens have been included in Megazospora tuberculosa. This decision has been supported afterwards by the discovery of pannarin-contsining specimens in southern Brasil and the Caribbean region. 


\section{chapter 6. KEYS}

A. Key to the genera of crustose Lecanorales with discoid apothecia and large, bicellular spores

la Hymenium containing oil droplets, often I -

Megalosporaceae (key C)

b Hymenium clear, always I + intensely blue

2a Spores single in each ascus; excipulum thalloid

Lecania sulphureofusca (p. 179)

b Spores 2-8 in each ascus; excipulum biatorine

Catillaria (key B)

B. Key to the Catinoria species with large spores

la Spores 1-2 in each ascus, over 40 um long

b Spores 8 in each ascus, under 40 um long

Catinaria sp. div. (not treated)

2a Isidia present, spherical to clavate, c. $0.1-0.2 \mathrm{~mm}$ long; India

Catinaria isidiza (p. 171)

b Isidia absent; America or Africa

3a Apothecia usually over $1 \mathrm{~mm}$ wide, with medullary excipulum, remaining more or less flat Catinaria versicolor (p. 172)

b Apothecia up to $1 \mathrm{~mm}$ wide, without medullary excipulum, soon becoming convex Catinaria microcarpa (p. 172) 
C. Key to the Megalosporaceae

la Spores bicellular 2

b Spores pluricellular, bacillar 20

c Spores pluricellular, muriform $\quad 34$

2a Spore septa and apical walls thick (cf. p. 45, fig. 6 E) 37

b Spore septa and apical walls thin (cf. p. 45, fig. 6 A, B) 3

3a Spores always single in each ascus, straight, elongate, usually 3 or more times as long as wide

b Spores with (1-)2-8 in each ascus, usually curved and less than 3 times as long as wide

4a Thallus whitish, $\mathrm{P}+$ orange, $\mathrm{KC}$ - (pannarin)

7. Megalospora gomphotoma..............

b Thallus yellowish, P -, KC + yellow (usnic acid)

5a Orangebrown layer present below the hymenium (observe with incumbent light); New Zealand 7b. M. gompholoma ssp. gompholoma (p. 105)

b Darkbrown layer present below the hymenium; Australia

7a M. gompholoma ssp. fuscolineata (p. 103)

6a Soredia present

b Soredia absent

7a Soredia granular, often spreading over most of the thallus; apothecial margin yellowish; New Guinea 8. Megalospora granulans (p. 106)

b Soredia farinose, mostly limited to punctiform soralia; apothecial margin black; Japan 5c. Megalospora atrombicans ssp. sendaiensis (p. 99)

8a Isidia present 6. Megalospora bartlettii (p. 101)

b Isidia absent

9a Spores under $100 \mu \mathrm{m}$ long 10

b Spores over $100 \mu \mathrm{m}$ long 
10a Apothecium margin yellowish 10. Megalospora sulphureorufa (p. 110)

b Apothecium margin brown to black

11a Apothecia obconical 9. Megalospora hillii (p. 108)

b Apothecia with flat lower side

5. Megalospora atrombicans.............12

12a Apothecium margin black, in older apothecia disappearing

5c. M. atrorubicans ssp. sendaiensis (p. 99)

b Apothecium margin pale to black, persistent

13a Thin orangebrown layer present below the hymenium (observe with incumbent light); apothecia usually over $1 \mathrm{~mm}$ wide

5a. M. atromubicans ssp. australis (p. 97)

b No such layer present; apothecia usually under $1 \mathrm{~mm}$ wide

5b. M. atrorubicans ssp. atrombicans (p. 95)

14a Apothecia obconical 11. Megalospora weberi (p. 112)

b Apothecia with flat lower side

15a Thallus whitish, $\mathrm{P}+$ orange, $\mathrm{KC}-$ (pannarin)

12. Megalospora campy Zospora (p. 114)

b Thallus yellowish, $\mathrm{P}-, \mathrm{KC}+$ yellow (usnic acid)

16a All spores under 45 m long

b Most or all spores over 45 m long

17a Soralia present, 0.5 - 1 mm wide; New Zealand

15. Megalospora subtuberculosa (p. 123)

b Soralia absent; Australia 14. Megalospora melanodermia (p. 120)

18a Epithecium with thick, granular layer which penetrates up to $70 \mathrm{\mu m}$ into the hymenium

13. Megalospora knightii (p. 117)

b Epithecium without granules

16. Megalospora sulphurata. 
19a Epithecium orange-brown to brown

$$
\text { var. sulphurata (p. 125) }
$$

b Epithecium olive-green to olive-brown or darkbrown

$$
\text { var. nigricans (p. 131) }
$$

20a(1) Spores single in each ascus, straight

$21 \mathrm{a}$ Thallus yellowish grey, $\mathrm{P}-, \mathrm{KC}+$ yellow (usnic acid)

b Thallus whitish grey, P + orange, KC - (pannarin)

22a Hymenium over $200 \mu \mathrm{m}$ high; excipulum in section $\mathrm{K}+$ yellow

24. Megalospora halei (p. 152)

b Hymenium under $200 \mathrm{~mm}$ high; excipulum in section usually $\mathrm{K}$ -

26. Megalospora tuberculosa (p. 156)

23a Spores over $150 \mu \mathrm{m}$ long

22. Megalospora albescens (p. 148)

b Spores usually under $100 \mu m$ long

24a Algae present in the apothecium margin (ectal excipulum)

23. Megalospora australiensis (p. 150)

b No algae present in the apothecium margin

25a Apothecia \pm concave with inflexed, bluish margin; Australia

25. Megalospora inflexa (p. 154)

b Apothecia plane to convex, with more or less prominent, pale brown to black margin; subcosmopolitic, not in Australia

26. Megalospora tuberculosa (p. 156)

26a Thallus yellowish grey, $\mathrm{P}-, \mathrm{KC}+$ yellow (usnic acid)

b Thallus whitish grey, P + orange, KC - (pannarin)

27a Apothecial margin brown to black; spores with completely thin septa

21. Megalospora thomensis (p. 146)

b Apothecial margin pale yellowish; spores with thick rings along the attachment lines of the septa

18. Megalospora maderensis (p. 137) 
28a Spores with thick septa with clear pores, always three-septate, 35-40 $\mathrm{mm}$ Iong

1. Austroblastenia pauciseptata (p. 82)

b Spores with thin septa without clear pores, usually 5-11-septate, over 60 im long

29a Apothecial margin pale; spores 70-105 $\mu \mathrm{m}$ long

b Apothecial margin darkbrown to black; spores 90-140 um long

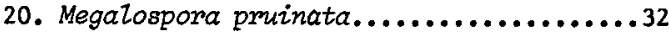

30a Hymenium 105-180 um high; 1ichexanthone present (UV + orange)

19. Megalospora pachycheiza (p. 139)

b Hymenium 200-280 um high; pannarin present (UV - or + white)

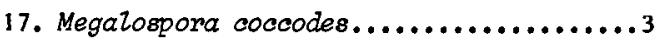

31 U Upper part of ectal excipulum with white, elongate, c. $4 \times 1$ um large crystals; SE Asia 17b. M. coccodes ssp. nigmicans (p. 135)

b Upper part of ectal excipulum with tiny yellowish crystals; Africa and America

17a. M. coccodes ssp. coccodes (p. 132)

32a Hymenium under $190 \mathrm{~mm}$ high 20c. M. priinata ssp. pruinata (p. 145)

b Hymenium over $220 \mu \mathrm{m}$ high

33a Apothecia black, sometimes with a bluish-white pruina; Indonesia, Malaya, Sabah 20b. M. pruinata ssp. Zamii (p. 143)

b Apothecia very dark brown, sometimes with a slight grey pruina; New Guinea 20a. M. pruinata s8p. fusca (p. 141)

34a(1) Spores with thick transverse septa, 4-8 per ascus

2. Austroblastenia propa (p. 84)

b Spores only with thin septa, solitary

35a Thallus whitish grey, P + orange, KC - (pannarin); spores 60-90 $\mu \mathrm{m}$ long

b Thallus yellowish grey, P -, KC + yellow (usnic acid); spores c. 115 jm long 29. Megazospora queensiandica (p. 168) 
36a Apothecia large, usually 1.5-2 mm wide, darkbrown to black, remaining flat with thick, prominent margin; Australia

28. Megalospora Zopadioides (p. 165)

b Apothecia smal1, 0.7-1.3 mm wide, brown, convex with thin margin; southern South America 27. Megalospora kalbii (p. 164)

37a(2) Thallus yellowish grey, P -, KC + yellow (usnic acid); apothecia black

3. MegaLoblastenia flavidoatra (p. 87)

b Thallus whitish grey, P + orange, KC - (pannarin); apothecia more or less grey-pruinose 4. Megaloblastenia marginiflexa...........38

38a Subhypothecium dark brown var. marginiflexa (p. 89)

b Subhypothecium pale var. dimota (p. 93) 


\section{chapter 7. TAXONOMIC TREATMENT OF THE MEGALOSPORACEAE}

\section{Megalosporaceae Vezda ex Hafellner * Bellemère}

Nova Hedwigia 35: 216 (1982); - Megalosporaceae ad. int., VEZDA, Acta Mus. Silesiae, ser. A, 23: 176 (1974).

type genus: Megalospora MEYEN

Thallus crustose, yellowish-, greenish- or whitish grey, c. 50-150 $\mu \mathrm{m}$ thick. Surface smooth or rugulose, bare or sometimes with cylindrical to coralloid, c. $0.2 \mathrm{~mm}$ thick isidia or soralia. No true differentiation of pseudo-tissues: whole thallus arachnoid, consisting of free hyphae composed of c. 4-6 x 3-2 $\mu \mathrm{m}$ large cells, but on top with a c. $10 \mu \mathrm{m}$ thick cortical layer of megalosporaceaetype (cf. p. 20). Algae present mainly in the upper $60 \mathrm{~mm}$ of the thallus, green, subsphaerical, 6-12 um diam. (Dictyochloropsis sp.). Chemistry: zeorin present with either usnic acid or pannarin or 1 ichexanthone.

Apothecia biatorine, sessile, scattered over the thallus, attached with the whole base, when juvenile concave with prominent margins, c. 0.5-1.3 $\mu$ m diam. and $0.5-0.9 \mu \mathrm{m} \mathrm{thick}$, in later stages flat or somewhat convex, 2-3(-5) mm diam. but hardly thicker than in the young stages. Disc brown to black, sometimes with a whitish pruina. Margin yellowish, brown or black, paler than the disc or concolorous or darker. Disc and margin usually slightly glossy.

Epithecium c. $15 \mu \mathrm{m}$ thick, usually diffusely orange-brown coloured, sometimes with other pigments or granular substances. Hymenium ranging from c. 110 to 300 $\mu m$ in thickness, colourless, inspersed with c. 1-7 $\mu \mathrm{m}$ large "oil droplets" or clear. Hymenial gelatine soft, usually extending for 1-3 $\mu \mathrm{m}$ above the paraphyse tips. I-reaction of the hymenium very variable: blue staining absent, or limited to a basal layer and/or the ascus tops, or whole asci turning blue, sometimes so intensely that the whole hymenium appears blue. Paraphyses 1 m thick, indistinctly septate with c. 7-10 $\mu \mathrm{m}$ long cells, parrallel-arranged with few anastomoses, in the epithecium less parallel and more branched and anastomosing, with slightly thickened, to $2(-3)$ mm thick tips.

Subhymenial layers (subhymenium + hypothecium) c. 70-110 رm thick, composed of

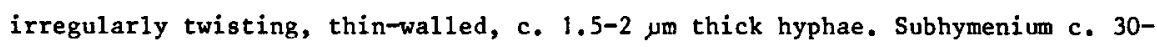
$50 \mu \mathrm{m}$ thick. Hypothecium usually 30-50 $\mu \mathrm{m}$ thick, less inspersed with oil droplets as the hymenium, and thus showing as a pellucid layer in fresh sections. 
Parathecium weakly differentiated, composed of a ring of \pm radiating hyphae around the subhypothecium. Parathecial crown not very clearly delimited, the transition from the hypotheciun to the ectal excipulum being very gradual.

Excipulum differentiated into a thin subhypothecium, a medullary excipulum and an ectal excipulum, composed of c. 3 m thick, more or less anticlinally arranged but winding hyphae with c. 1 m thick walls. Subhypothecium flat and c. 10-20 $\mu \mathrm{m}$ thick, or conical and to $70 \mu \mathrm{m}$ thick, sometimes indistinct, consisting of compacted hyphae running parallel to the hypothecium. Medullary excipulum arachnoid, often including crystal aggregates of Calcium Oxalate. Ectal excipulum c. $40 \mu \mathrm{m}$ thick, compact with dense and conglutinated hyphae which show many anastomoses and branchings but are hardly swollen, sometimes containing minute crystals. Brown or darkbrown pigments frequent, in the subhypothecium occurring as sheaths around the hyphae, in the ectal excipulum mainly in the interhyphal matrix, occasionally extending into the medullary excipulum, sometimes forming a continuation of the pigment of the epithecium which can be traced for a short distance in the ectal excipulum. Unknown substances A - E sometimes present, together with the substances of the thallus, in the medullary excipulum, as crystalline substances covering the hyphae.

Attachment layer present, c. $10 \mu \mathrm{m}$ thick, compact, composed of irregularly orientated, winding, thin hyphae. Apothecium base c. 300-500 $\mathrm{mm}$ wide in adult apothecia, with anchorage bundles.

Asci of the Lecanora-type (cf. p. 44), reaching to 23-30 $\mu \mathrm{m}$ below the surface of the disc, c. 3-5 times as long as wide. Wall c. 3 mm thick. Apical dome present, in young asci c. $20 \mu \mathrm{m}$ thick, with or without ocular chamber, in mature asci c. $8 \mu \mathrm{m}$ thick. I-reaction of the free asci upon treatment with k-solution: wall pale blue with a thin outer side more strongly blue; outer gelatinous sheath and cone around the ascus apex sometimes blue. Asci opening apically in an irregular fashion, the dome seemingly forming a ring around the opening.

Spores of the sulphurata-, atrorubicans-, tuberculosa-, coccodes-, albidula-, pauciseptata-, pupa- or lopadioides-type, see p. 44-45.

Pycnidia immersed in small wartlets, c. $0.3 \mathrm{~mm}$ wide. Walls c. 7 m thick, compact, composed of thin-walled, irregularly orientated hyphae. Conidiophores of bayonet-type (cf. p. 54). Pycnospores clavate-bacillar, c. $3.5 \times 0.8 \mu \mathrm{m}$.

Primary corpus (apothecium precursor) persistent, c. 100-200 $\mathrm{mm} \mathrm{diam.,} \mathrm{con-}$ taining straight, usually bundled ascogonia composed of c. 5-6.5 $\times$ 2.5-3.5 $\mathrm{mm}$ large cells. 


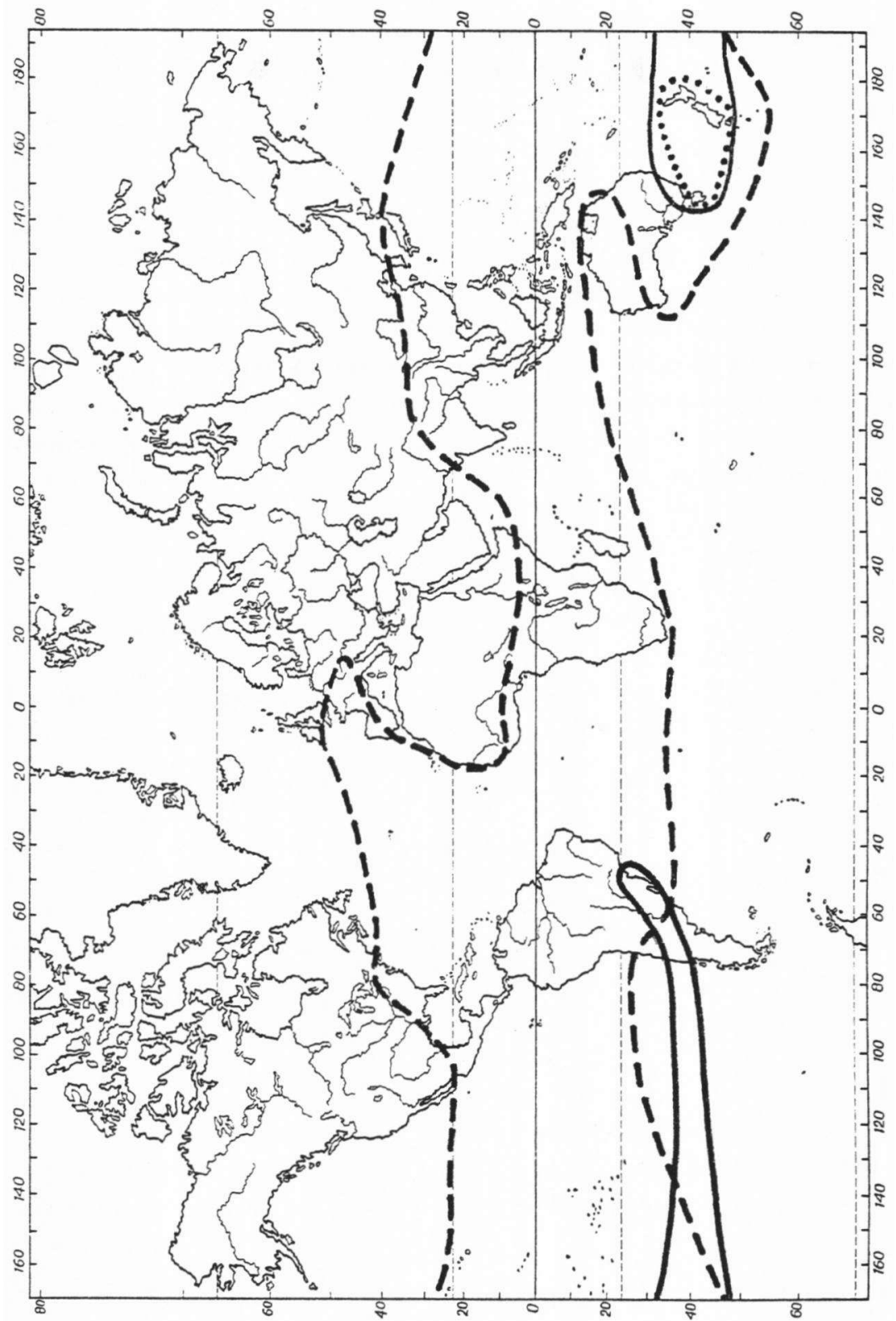

Figure 13. World distribution of the Megalosporaceae. Broken line = Megalospora; continuous line = Megaloblastenia; dotted line = Austroblastenia. 


\section{Remarks}

The family Megalosporaceae, as defined here, forms a very distinct and well characterised group. Very distinctive (except for the genus Megaloblastenia) is the high hymenium inspersed with numerous oil droplets, which usually does not become stained by I-solution, and shows thin, straight paraphyses. The large asci produce a usually reduced, 1 or c. 2-5(-8), number of large, bi- or pluricellular spores which measure usually over $50 \times 30 \mu \mathrm{m}$. The apothecia are biatorine and the medullary excipulum contains usually acetone-soluble substances. The chemical variation of the thallus is limited to three combinations of substances, zeorin with usnic acid, zeorin with pannarin and in a single species zeorin with lichexanthone.

Figure 13 gives the world distribution of the family, which is discussed on p. 188 .

\section{Austroblastenia gen. nov.}

type species: Austrobzastenia pauciseptata.

Diagnosis: Descriptionem familiae oboedit, sed thallo sine sorediis vel isidiis, tantum substantias zeorinum et pannarinum continente; apotheciis margine fusco vel atro, hymenio 120-250 $\mu \mathrm{m}$ crasso, semper oleoso-insperso, excipulo substantiam ignotam B continente, subhypothecio pallido plano; sporis bacillaribus vel muriformibus, septis transversalibus crassis provisis, typo designato "pauciseptata" vel "pupa".

Agrees with the family description except for the following points: thallus without isidia or soredia, containing only zeorin and pannarin; apothecial mar-

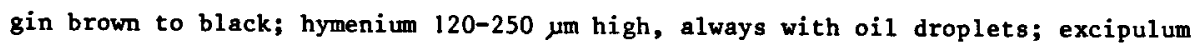
containing only unknown substance B; subhypothecium without dark pigments, flat; spores bacillar or muriform, with thick transverse septa, of pauciseptata- or pupa-type.

\section{Austroblastenia pauciseptata (Shirley) comb. nov.}

basionym: Heterothecium pauciseptatum SHIRLEY, Pap. \& Proceed. Roy. Soc. Tasmania for 1893, p. $218(1894)$

type: Australia, Tasmania, Mount Wellington, Bower Creek, on bark of tree, W. A. Weymouth, 10.VIII. 1889 (NSW) 
NOTE. In the original description (SHIRLEY 1894) the spores are stated to be "3-5-septate, with 1-3 cellules in each ce11". Examination of the type specimen revealed that the spores are uniformly three-septate with thick septa and without longitudinal septa.

\section{Description}

Thallus pale grey to whitish grey, usually rather thick and cracked, rugulose to warted, with warts c. 0.4-0.8 $\mu$ wide and of ten bursting and developing into superficial or capitate soralia. Soredia often present, 20-40 $\mu m$ diam.. Isidia absent. Chemistry: pannarin and zeorin.

Apothecia c. $1.5 \mathrm{~mm}$ wide, $0.7-0.8 \mathrm{~mm}$ when young, and up to $3.5 \mathrm{~mm}$ and then often regenerated into a convex group of small apothecia, 410-520 $\mathrm{mm}$ thick. Disc flat, in the larger apothecia convex, brown or darkbrown, epruinose, glossy. Margin only in young apothecia more or less prominent, rather thin, brown to darkbrown, slightly darker than the disc or pale, epruinose, glossy, in larger apothecia flexuous.

Epithecium diffusely orangebrown, 15-30 $\mu \mathrm{m}$ thick. Hymenium 120-180 $\mu \mathrm{m}$ high, more or less clearly $I+$ blue in asci and sometimes also basal part of the hymenium. Excipulum pale brown to hyaline, K-. Apothecial base c. 460 رm wide. Apothecium chemistry: unknown substance $B$ in variable amounts, sometimes nearly absent. Crysta1s of Calcium Oxalate absent.

Spores (4-) 8 per ascus, bacillar, three-septate with thick septa (pauciseptata-type, p. 45 Fig. 6 F), 34-40 x 14-20 $\mu \mathrm{m}$. Spore wall 2.5 رm thick, including a c. 1 m thick outer layer, smooth. Septa c. 6 رm thick with wide central pore.

Pycnidia not observed.

Distribution and ecology

Austroblastenia pauciseptata is known from Tasmania and New Zealand (fig. 14). In New Zealand it was found to be common in stunted Podocarpaceaeforest near Otira at 500-1000 m altitude. In Nothofagus solondri var. cliffortioides-forest in the same area it was much less common, and apparently restricted to the wettest parts. It grows on treetrunks on open places. In Tasmania are given as phorophytes: Nothofagus cuminghomii, Phyllocladus aspleniifolia and Anodopetalum biglondulosum.

\section{Remarks}

Austroblastenia pauciseptata differs much from the Megalospora species by its 


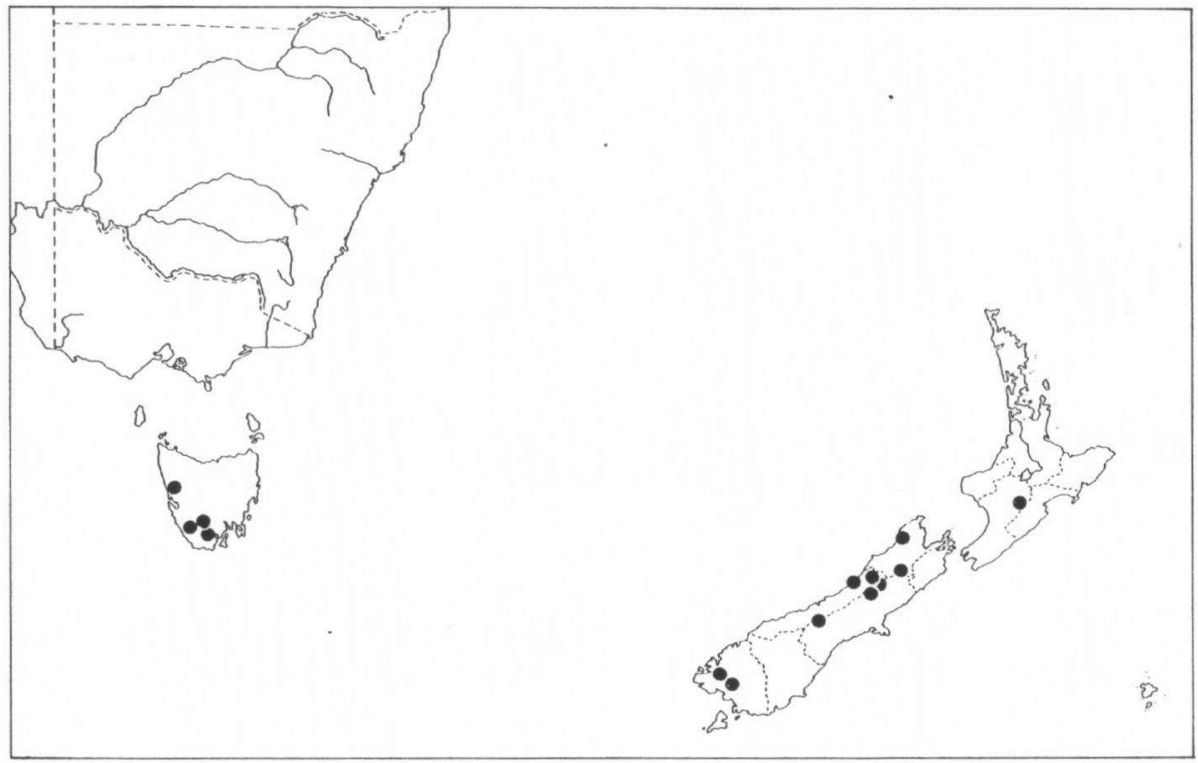

Figure 14. Austroblastenia pauciseptata, distribution.

spores which resemble most closely those of $A$. pupa by their thick transverse septa. Moreover the apothecia have a waxy tinge when wet, unlike in any Megalospora species.

A collection from Otira (Sipman 16791) is remarkable by its peculiar spores. These are nearly spherical with one or two thick, radially arranged septa (P1. $21 \mathrm{~B})$. It is considered to be an anomaly of the pauciseptata-type spores, because the specimen does not show any other significant differences with the present species.

\section{Austroblastenia pupa spec. nov.}

type: New Zealand, South Island, Cascade Cove (W-side), Dusky Is1and, D. Galloway, 18.II.1969 (CHR)

Diagnosis: Thallus albescens, rugulosus vel planus, sorediis isidiisque destitutus, pannarinum et zeorinum continens. Apothecia c. $1.2 \mathrm{~mm}$ lata et $450-650(-700)$ $\mu m$ crassa; discus persistenter planus, fuscus, obscuriter pruinosus, opacus; margo prominens, niger, epruinosus, nitidus; epithecium diffusiter flavido- 
rufum vel rufum, strato granulare obtectum, 18-24 um crassum; hymenium 180-250 um crassum, I + obscuro-coerulescens; excipulum flavido-fuscum, in parte externa fusciore et in hypothecio strato rufo persistente provisum, $\mathrm{K}+$ flavescens; basis apothecii 450-600 $\mu \mathrm{m}$ latus; substantiam ignotam B continentia, crystallis calcii-oxalaticis destituta. Sporae quadernae usque ad octonae, muriformes (typo "pupa"), e 10-14 x 4-5 cellulis compositae, magnitidine 45-80 x 23-32 $\mu \mathrm{m}$, pariete c. 1 m crasso, septis transversalibus in parte externa 1 mm crassis et in parte centrali c. $0.5 \mu \mathrm{m}$ crassis, strato externa c. 1 m crasso laeve. Sylvarum humidarum subalpinarum Novae Zelandiae incola.

\section{Description}

Thallus pale grey to pale greenish grey, thin, smooth or slightly rugulose, occasionally thicker and cracked. Soredia and isidia absent. Chemistry: pannarin and zeorin.

Apothecia c. $1.2 \mathrm{~mm}$ wide, 0.6-0.8 $\mathrm{mm}$ when young, and up to $2.1 \mathrm{~mm}, 450-650$ (-700) $\mu \mathrm{m}$ thick. Disc flat, also in the largest apothecia, brown with a slight but coarse whitish pruina, dull. Margin very prominent but narrow, black, epruinose, glossy.

Epithecium diffusely pale yellowish-, orange- or reddish brown with a granular top-layer which disappears in lactophenol-cotton blue preparations, 18-24 $\mu \mathrm{m}$ thick. Hymenium 180-250 $\mathrm{m}$ high, I + dark blue. Excipulum yellowish brown, darker in the ectal parts, with a thin orangebrown layer in the subhypothecium which does not disappear after acetone-washing, $\mathrm{K}+$ yellow. Apothecium base 450-600 $\mu \mathrm{m}$ wide. Apothecium chemistry: unknown substance B. Crystals of Calcium Oxalate absent.

Spores 4-8 per ascus, muriform with thick transverse septa and thin longitudinal septa (pupa-type, p. $45 \mathrm{Fig} .6 \mathrm{G}$ ), 45-80 x 23-32 $\mu \mathrm{m}$, in section composed of 10-14 × 4-5 cells. Spore wall c. 2 pm thick, including a distinct, c. $1 \mathrm{fm}$ thick outer layer, smooth. Transverse septa in outer part 1 um thick, in central part $0.5 \mu \mathrm{m}$.

Pycnidia not observed.

\section{Distribution and ecology}

Austroblastenia pupa is known only from four localities in New Zealand, three on the South Island and one om the North Island (Fig. 15). In Otira the species was abundant on smooth bark of treetrunks in stunted open Podocarpaceae-forest on a mountain ridge at c. 500-1000 m elevation.

\section{Remarks}

The present species is well characterised by its peculiar spores and the small apothecia with brownish pruinose disc and prominent margin. Its spore 


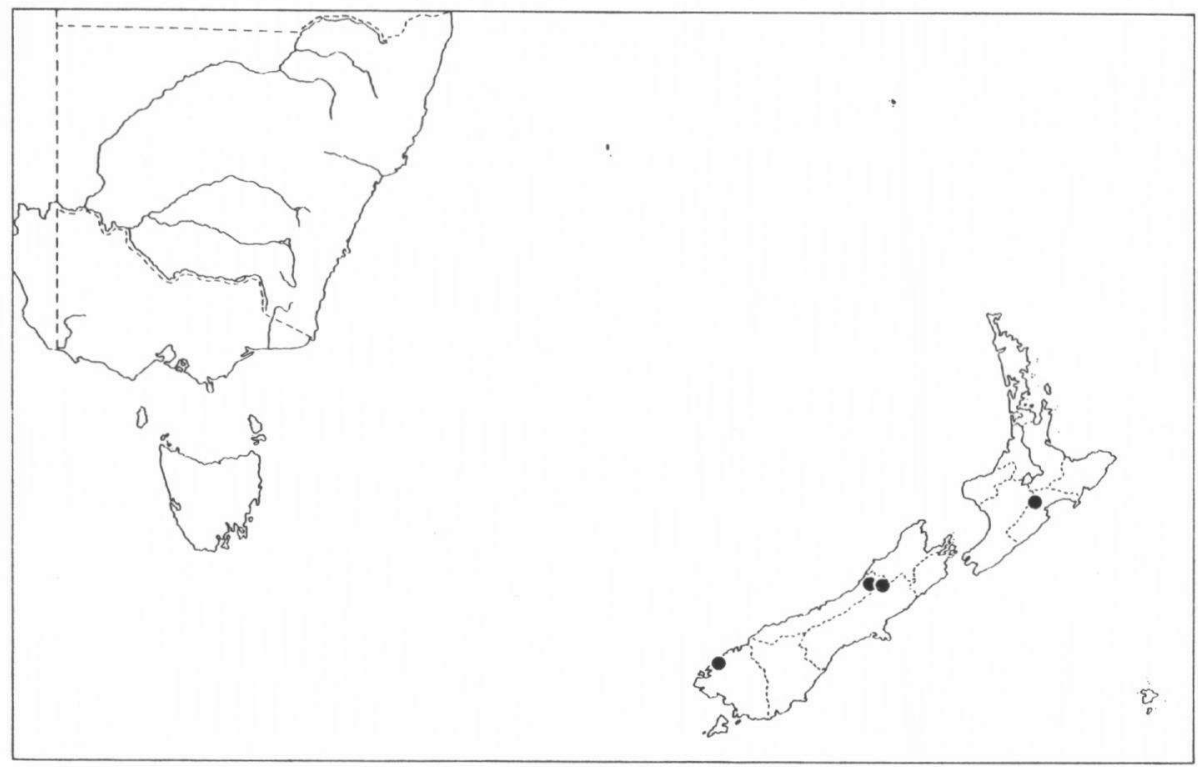

Figure 15. Austroblastenia pupa, distribution.

type deviates much from the usual types in the Megalosporaceae, but can be rather easily derived from the spore type of Austroblastenia pauciseptata. In other respects A. pupa comes close to other species of the family, by its structure of apothecia and asci, the persistence of the primary corpus, the chemistry of the thallus and the apothecia.

Well developed spores appear to be rare in the present species: among the available collections only the type collection has a reasonable quantity of spores in various developmental stages in the apothecia. In all other collections only a few more or less degenerated spores were present. 
Megaloblastenia gen. nov.

Diagnosis: Descriptionem familiae oboedit, sed: thallo isidiis destituto; hymenio 110-180 $\mu \mathrm{m}$ crasso claro, reactione iodii forte coerulescente; subhypothecio plus minusve conico; sporis bicellularibus septis et parietibus apicalibus crassis.

Agrees with the family except for the following points: thallus without isidia; hymenium 110-180 $\mu \mathrm{m}$ high, without oil droplets and clearly stained blue by I-solution; subhypothecium more or less conical, to $70 \mu \mathrm{m}$ thick; spores bicellular with thick septa and polar walls (albidula-type).

type species: Megaloblastenia flavidoatra.

\section{Megaloblastenia flavidoatra ( $\mathrm{Nyl}$ ) comb. nov.}

basionym: Lecidea flavidoatra NYLANDER, J. Linn. Soc. London, bot. 9: 257 (1865) orig. mat.: New Zealand, Dunedin, ad corticem arborum, L. Lindsey (not seen)

\section{synonyms:}

Patellaria flavidoatra (NYL.) MUELLER ARG., Bull, Herb. Boissier 2, append, 1: 64 (1894); - Catillaria flavidoatra (NYL.) HELLBOM, Bih. Kg1. Svensk. Vetensk.Akad. Handl. 21, afd. 3 no. 3: 111 (1896).

\section{Description}

Thallus pale greenish yellow, rather thick, rugulose to crowded-warted (warts 0.1-0.2 mm wide). Isidia and soredia absent. Chemistry: usnic acid and zeorin.

Apothecia scattered to rather crowded, c. $1 \mathrm{~mm}$ diam., $0.5 \mathrm{~mm}$ when young, and up to $1.9 \mathrm{~mm}$, c. $350 \mu \mathrm{m}$ thick. Disc flat, even in the largest apothecia hardly convex, black, dull. Margin little prominent, rather thin, black, slightly glossy.

Epithecium diffusely darkbrown to nearly black, c. 30 m thick. Hymenium 100$160 \mu \mathrm{m}$ high, I + blue. Excipulum darkbrown, sometimes with a greenish tinge, with a darker ectal excipulum and subhypothecium, $K+$ red. Apothecium base 400$550 \mathrm{rm}$ wide. Apothecium chemistry: unknown substances A (trace), D and E. Crystals of Calcium Oxalate absent.

Spores usually eight per ascus, bicellular with thick walls, more strongly thickened septa (to $9 \mu$ mo thick) and polar walls, rounded lumina and widely pored septa, sometimes slightly curved (albidula-type, p. 45 Fig. 6 E), 34-40 x 18-23 $\mu \mathrm{m}$. Spore wall c. $3 \mu \mathrm{m}$ thick, smooth, including a distinct, c. 1 m thick outer layer.

Pycnidia not observed. 


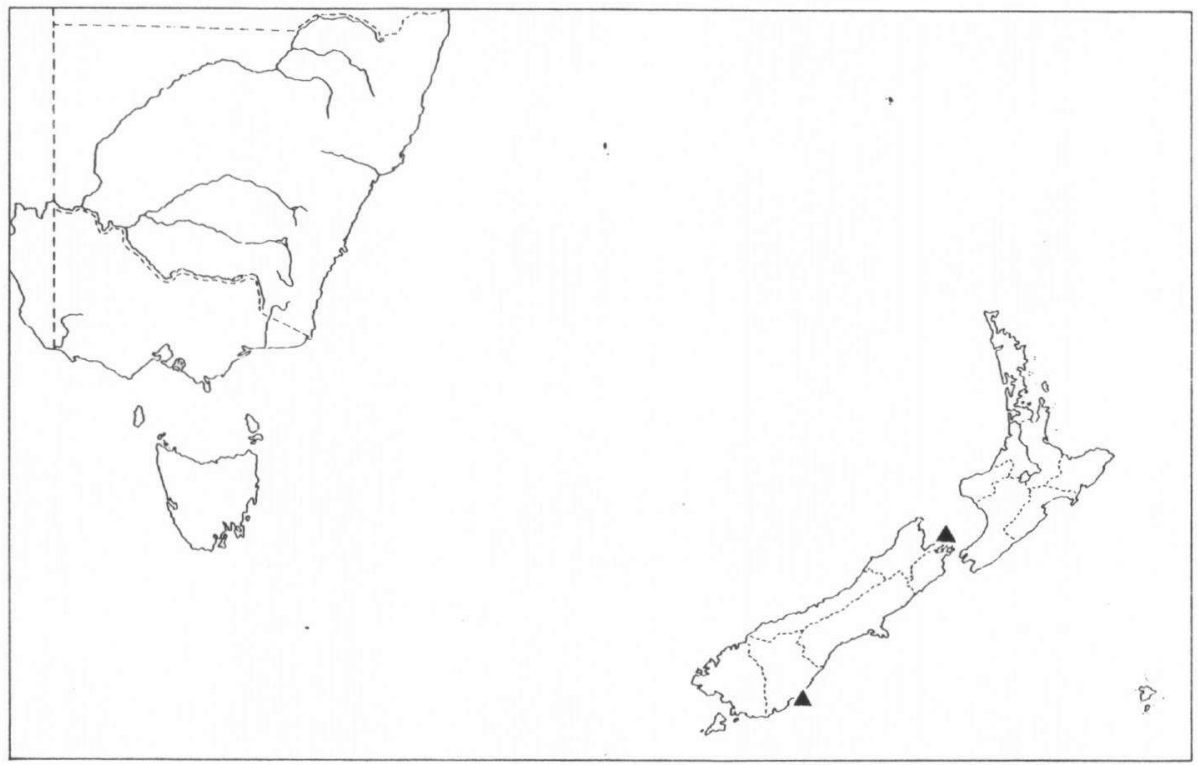

Figure 16. Megaloblastenia flavidoatra, distribution.

Distribution and ecology

The few records of the present species are all from the South Island of New Zealand (Fig. 16). As phorophyte Metrosideros is mentioned. All specimens are on, probably rough, bark.

\section{Remarks}

The present species resembles clearly Megaloblastenia marginiflexa by its spores and hyaline hymenium. But the small, black apothecia and the warted yellowish thallus are very distinctive.

The specimen cited in the original description was not available for study, but another specimen from Nylander's herbarium with the annotation "Lecidea flavidoatra" in his own handwriting has been investigated. 
4. Megaloblastenia marginiflexa (Hook. \& Tayl.) comb. nov. var. marginiflexa (P1. 2 C).

basionym: Lecidea marginiflexa HOOKER \& TAYLOR, London J. Bot. 3: 638 (1844).

type: New Zealand, Kawakawa, Apri1 1843, hb. Hooker ( $K$ in BM)

NOTE. For the typification see the remark on p. 92,

synonyms:

Biatora marginiflexa (HOOK. \& TAYL.) BABINGTON apud HOOK., Flora Nov. Zeland. 2: 299 (1855) (name but not interpretation); - Psorothecium marginiflexu (HOOK. \& TAYL.) MASSAL., Atti I. R. Istit. Veneto, ser. 3, 5: 261 (1860) (name but not interpretation); - Patellaria marginiflexa (HOOK. \& TAYL.) MUELLER ARG., Flora 65: 330 (1882) (Lich. Beitr. 433) (name but not interpretation); - Megalospora marginiflexa (HOOK, TAYL.) A. ZAHLBR., Catal. Lich, Univ. 4: 88 (1927) (name but not interpretation).

Lecidea endochromoides NM., Ann. Sci. Nat., ser. 5, 7: 326 (1867); - Blastenia endochromoides (NYL.) MUELLER ARG., Bull, Herb. Boissier 2, append, 1: 69 (1894).

type: Chile, Cordillera de Ranco, ad corticem, Lechler (H-Nyl. nr. 18191).

Lecanora albidula FEE, Bull. Soc. Bot. France 20: 315 (1873).

type: Brasil, Glaziou 5003 ( $P C$, isotypes in G, M)

? Lecidea radomma NYL, in KNIGHT, Transact. \& Proceed. New Zea1. Instit. 7: 357 (1875); - Blastenia radomma (NYL.) A. ZAHLBR., Catal. Lich. Univ. 7: 40 (1931); CaZoplaca radomma (NYL.) A. ZAHLBR., Catal. Lich. Univ. 7: 179 (1931). type: New Zealand, on bark of trees, Knight ? (not seen)

NOTE. The original description fits Megaloblastenia marginiflexa very well, but no type specimen was available. The type indication is very vague. Perhaps a type can be found in the knight herbarium in WELT.

Lecidea iodomma NY., Lich. Nov, Zeland.: 89 (1888); - Blastenia iodomma (NYL.) A. ZAHLBR, , Catal. Lich. Univ. 7: 32 (1931).

type: New Zealand, leg. Knight 85 (H-Ny1. nr. 18192)

NOTE. The type specimen falls completely within the range of variation of MegaZoblastenia marainiflexa.

Description

Thallus whitish grey to grey, rather thin to thin, rugulose or nearly smooth, irregularly cracked when thick. Isidia absent. Soralia occasionally present, superficial, rounded, more or less concave, 0.5-1.5 mm diam., with soredia of 40$60 \mu \mathrm{m}$ diam., sometimes confluent. Chemistry: pannarin and zeorin.

Apothecia scattered or rather crowded, c. $1.5 \mathrm{~mm}$ diam., 0.5-0.9 mnen young, and up to $3 \mathrm{~mm}, 300-650 \mu \mathrm{m}$ thick. Disc flat, only in large apothecia of over $1.5 \mathrm{~mm}$ diam. slightly convex, darkbrown with a purplish tinge, or paler be- 
cause of the presence of a white pruina, dull. Margin prominent, rather thick, in large apothecia flexuous, more or less concolorous with the disc, dull.

Epithecium granularly brownish, 12-24 $\mu$ m thick. Hymenium (105-)110-150(-180) $\mu \mathrm{m}$ high, I + blue mainly by staining of the asci. Excipulum yellowish with usually a brown rim along the disc, of ten with a brown, usually conical subhypothecium, K + yellow. Apothecium base 250-450 $\mu \mathrm{m}$ wide. Apothecium chemistry: unknown substance B. Crystals of Calcium Oxalate sometimes present in the medullary excipulum.

Spores eight per ascus or in a slightly reduced number, bicellular with thick walls and thicker polar walls and septa, the latter with wide pores (a1-

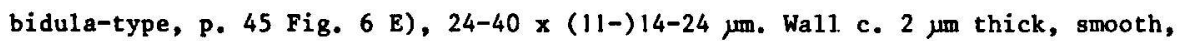
including a distinct, c. $0.5 \mu \mathrm{m}$ thick outer layer.

Pycnospores bacillar, $3 \times 0.5 \mu \mathrm{m}$.

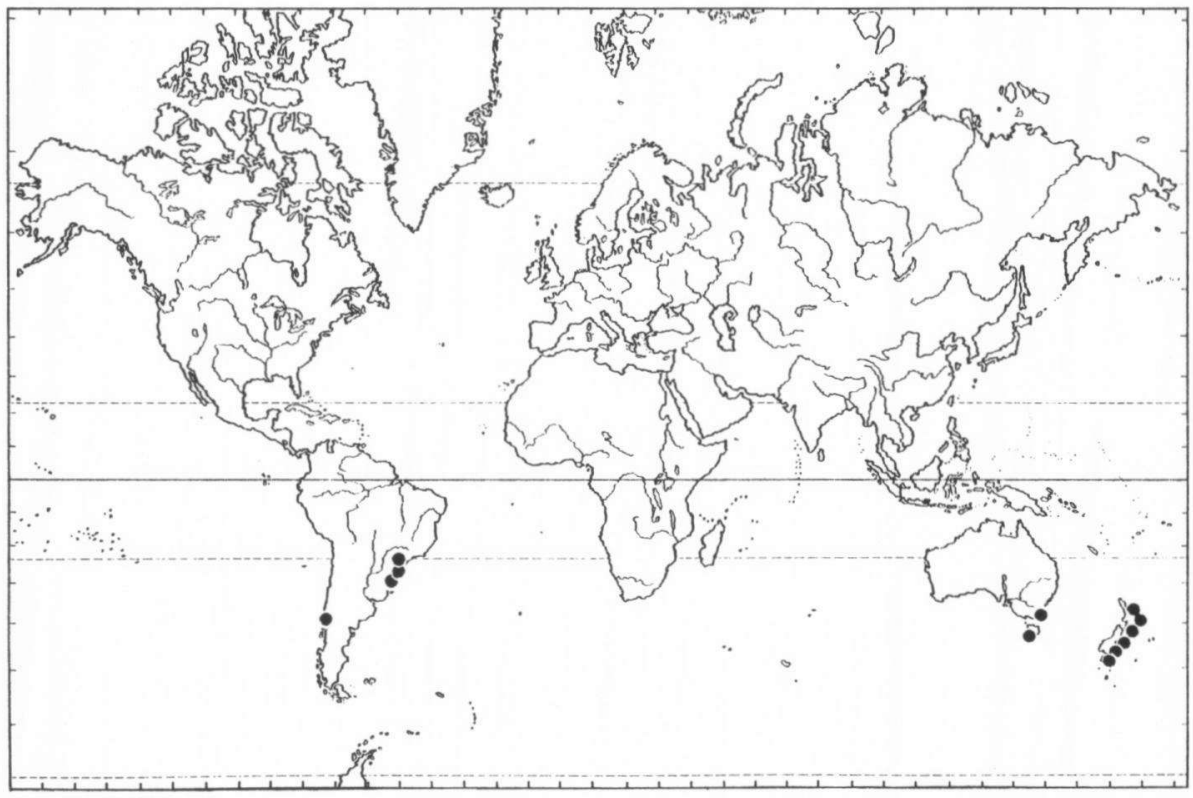

Figure 17. Megaloblastenia marginiflexa, world distribution. 
Distribution and ecology

The range of Megaloblastenia marginiflexa is remarkably disjunct and includes southern Australia (Tasmania and Victoria), New Zealand, central Chile and southern Brasil (Fig. 17, 18). Nearly all specimens are from bark and a few from wood. Apparently the species prefers smooth bark of trees in open forest. As phorophytes in New Zealand are recorded: Aristotelia, Beilschmidia and Nothofagus. Altitude records are scarce and range from 200 to c. $800 \mathrm{~m}$.

\section{Remarks}

Megaloblastenia marginiflexa is well characterised by its spores, which resemble those in Physcia but are colourless. The only other species with such spores, Megaloblastenia flavidoatra, is very distinct by its smaller, black apothecia and yellowish thallus.

Most of the plants from southern Brasil differ by the absence of brown pigwent in the subhypothecium, and are treated as a separate variety here, cf. p. 93.

Superficially Megaloblastenia marginiflexa resembles MegaZospora gompholoma. Besides by the completely different spores, it may be separated from this spe-

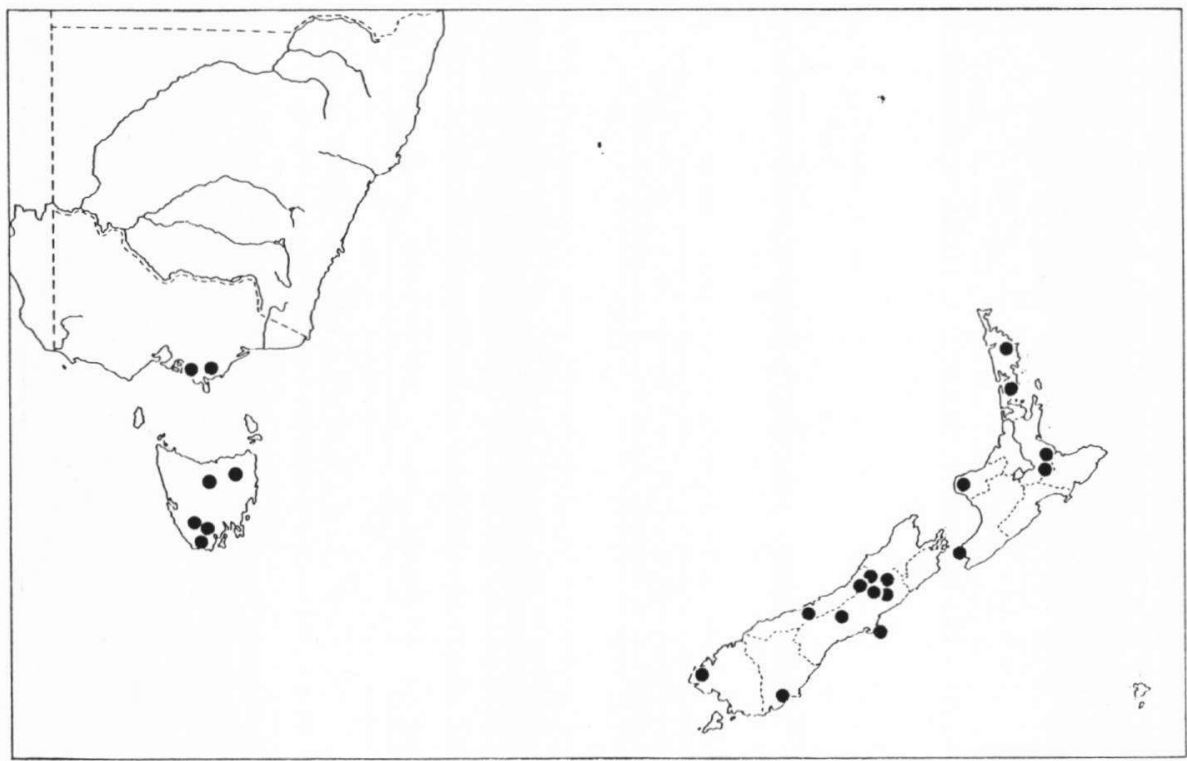

Figure 18. Megaloblastenia marginiflexa, distribution in Australia and New Zealand. 
cies by the purplish tinge of the fruit, especially when wet.

Hitherto the name Blastenia endochromoides has been used for the present species, after Lecidea marginiflexa was incorrectly interpretated by BABINGTON (1855). The confusion has arisen because the original description of Lecidea marginiflexa does not indicate spore characters nor a type specimen. The spores were described afterwards as being large, bicellular and solitary, by BABINGTON (1855) after examination of some original material. Subsequently this spore type has been used as the principal distinguishing character for Lecidea marginifle$x a$. However, this implied that the specimens named as such do not have a clear flexuous margin, the character inferred by the specific name. This discrepancy raised some doubt about the correctness of BABINGTON's choice of material when describing the spore characters. To solve this discrepancy a reexamination of the original material has been made. For this investigation the autheticity of specimens has been determined by the presence of inscriptions in TAYLOR's handwriting, viz. "Lecidea marginiflexa" and "New Zealand" (Especially the characters " $d$ " and " $x$ " were considered discriminative). In this way sixteen specimens have been selected from BM and FH. This number could be reduced to thirteen because three specimens were evidently represented by duplicates. Six different species appeared to be represented. Of these, two species belonging to the genera Bacidia and Catinaria could be taken out of consideration because the specimens in question bear the indication "a state" or "a different state", which suggests that they were not considered typical by TAYLOR himself. Moreover they do not accord with the original description very well. The remaining ten specimens resemble eachother clearly by the presence of dark, rather large, pruinose apothecia. Five of them belong to Megalospora compylospora, four to $M$. gompholoma ssp. gompholoma, and one to Megaloblastenia marginiflexa. The second species is in accordance with the description of the spores by BABINGTON (1855). However, it differs from TAYLOR's original description in the following statements: "apotheciis confertis, madore purpureonigris", "margine tenui flexuoso", "the disc flat, when moist convex" and "lamina .... resting on an equally shallow layer which is brown, and lies on much white cortical matter". On the contrary the apothecia of the specimens of this species are not crowded, black when wet, with thick, non-flexuous margin, with concave disc which becomes flat when moist, and the hymenium ("lamina") rests on an excipulum that is nearly completely brown-black, at least more strongly so in its ectal parts ("cortical matter"). The same arguments exclude Megalospora campyZospora. Only the specimen of Megaloblastenia marginiflexa fits TAYLOR's protologue in all ways. Therefore it has been accepted as the type specimen here. Very likely it is the same 
specimen as illustrated by BABINGTON (1855, P1. 129B, Fig. 1 left), which is illustrated on P1. 24 D, lower specimen. Apparently by mere chance BABINGTON has taken the other illustrated specimen for the investigation of the spores (cf. P1. 24 D, upper specimer).

4. Megaloblastenia marginiflexa var. dimota (Malme) stat. nov.

basionym: Megalospora dimota MALME, Ark. Bot. 18, no. 12: 8 (1923).

type: Brasil, Rio Grande do Sul, Silveira Martins, G. A. Malme, Exp. Regnell. Lich, 1186 (S LECTOTYPE NOV., US)

NOTE. MALME mentions three collections in his original description, all of which belong to the present variety. As lectotype has been choosen the specimen with a duplicate in a second herbarium.

This variety is characterised by the absence of darkbrown pigment in the subhypothecium.

The localities of this variety are all in southern Brasil, from the southern parts of Minas Gerais and Rio de Janeiro to Rio Grande do Sul. It seems to prefer rather smooth bark in light forest. In the northern part of its range it has been collected in the mountains, e.g. at an elevation of $1750 \mathrm{~m}$ in the Serra da Itatiaia, but it has also been collected in mangroves, e.g. near Sao Paulo.

The rank of variety has been choosen because the pale subhypothecium is the only distinguishing character. All brasilian specimens of Megaloblastenia marginiflexa belong to it, except for one, the type of Lecanora albidula, which has a brown subhypothecium.

Megalospora Meyen, in MEYEN \& FLOTOW,

Verh. kaiserl. Leopo1d.-caro1. Ak. Naturf. 19, Supp1. 1: 228 (1843)

Type species: Megalospora sulphurata.

synonyms :

Lecidea subg. Megalospora (MEYEN) BOIST., Nouv. Flore Lich., 2: 202 (1902)

(comb. but not interpr.); Heterothecium sect. Megalospora (MEYEN) TUCKERM., Synops. North Amer. Lich. 2: 53 (1888).

Heterothecium FLOTOW, Bot. Zeitung 8: 368 (1850) (nomen superf1.)

Type species: not indicated.

NOTE. FLOTOW (1850) introduced the name Heterothecium for Megalospora because he considered that name inappropriate (SANTESSON 1952). Thus Megalospora sulphu- 
rata should be the type species, but no formal combination is made.

Psorothecium MASSAL., Atti Isit. Veneto, ser. 3, vo1. 5: 60 (1860); - Lecidea subg. Psorothecium (MASSAL.) WAINIO, Acta Soc. Fauna F1. Fenn. 7(2): 34 (1890);Heterothecium sect. Psorothecium (MASSAL.) TUCK., Synops. North Amer. Lich. 2: 54 (1888); - Patellaria sect. Psorothecium (MASSAL.) MUELLER ARG. in A. ZAHLBR., Catal, Lich. Univ. 4: 86 (1927).

NOTE. MUELLER ARG. (1894, p. 63) did not attribute a formal taxonomic rank to

Psorothecium.

Lectotype species: Psorothecivm taitense (MONT.) MASSALONGO (= Megalospora sulphurata).

NOTE. STIZENBERGER (1862, p. 160) made a lectotypification by stating for his Psorothecizm sect. Eupsorothecium "Ex. P. taitense".

Bombyliospora DE NOT., in MASSAL., Ricerch. Auton. Lich., p. 114 (1852); Lecidea subg. Bombyliospora (DE NOT.) WAINIO, Acta Soc. Fauna Fl. Fenn. $7(2): 30$ (1890); - Psorothecium sect. Bombyliospora (DE NOT.) STIZENB.. Ber. Thatigk. St. Gallisch. naturwissensch. Ges. 1862, p. 160 (1862); - Heterothecivon sect. BombyZiospora (DE NOT.) TUCK., Synops. North Americ. Lich. 2: 55 (1888); - Patellaria sect. Bombuliospora (DE NOT.) MUELLER ARG., Bull. Herb. Boissier 2, append. 1: 65 (1894).

Lectotype species: Psorothecivon tuberculosum (FEE) STIZENBERGER (- Megalospora tuberculosa).

NOTE. STIZENBERGER (1862, p. 160) made a lectotypification when he stated for his Psorothecizm sect. Bombyliospora: "Ex. P. tuberculosim (FEE)".

Drmoutinia STEIN, 60 Jahresber. Schlesisch. Ges. vaterl. Kultur, p. 231 (1883). Type species: $D$. maderensis (KREMPELH.) STEIN (= Megalospora maderensis).

Bomby Ziosporomyces CIF. \& TOMAS,, Atti Istit, Bot, Univ. Lab. Crittog. Pavia ser. 5, 10: 63 (1953).

Type species: $B$. tuberculosae CIF. TOMAS. nom. inval. (no description) NOTE. CIFERRI TOMASELLI (1953) give the new genus name on p. 37 in a key, without description. The latter is given on p. 63.

Lecania sect. Platylecania MUELLER ARG., Flora 65: 327 (1882) (Lich. Beitr. 425). Type species: $L$. complificans (NYL.) MUELLER ARG. (= Megalospora coccodes ssp. coccodes).

\section{Description}

Agrees with the description of the family, except for the following points: hymenium 80-260 $\mu$ migh, always with oil droplets; subhypothecium flat; spores bicellular or pluricellular, with thin septa (of sulphurata-, atrorubicans-, tuberculosa-, coccodes- or lopadioides-type).

\section{Remark}

No formal subdivision of the genus Megalospora has been made, because no subdivision could be found which is supported by a sufficient number of characters or other evidence to make probable that it reflects phylogenetical lines (cf. chapter 11). But for practical reasons the species have been arranged to their spore type in the taxonomic treatment. 
5a. Megalospora atrorubicans (Nyl.) A. Zahlbr., Catal. Lich. Univ. 4: 86 (1927) ssp. atrorubicans

basionym: Lecidea marginiflexa var, atrombicans NYLANDER, Flora 49: 132 (1866)

type: Indonesia, Java, ad corticem arborum circa Toegoe, alt. 3000 ped., Kurz 496, 17.II. 1861 (H-Nyl., ISO in M)

synomyms :

Patellaria atrombicans (NYL.) MUELLER ARG., Flora 65: 330 (1882) (Lich, Beitr. 434); - Psorothecium atrombicans (NYL.) YASUDA, Flechten Japans, p. 26 (1935).

Psorothecium schadenbergianum STEIN, 66 Jahresber. Schles. Ges, vaterl. Kultur 1888 , p. 142 (1888).

type: Philippines, Mindanao, an Kampherholz-rinden, Schadenberg 53 in hb. Stein (WRSL, ISO in G).

? Megalospora flavidula GROENHART, Reinwardtia 2: 398 (1954)

type: Indonesia, West Java, M. Gedeh, Tjibodas, $1450 \mathrm{~m}$, on branchlet of Psidium cattleuconum. Groenhart $8746=$ BO 7745, 24.IX.1952 (not seen)

\section{Description}

Thallus pale greenish or yellowish grey, rather thick, more or less rugulose, usually little cracked. Soredia and isidia absent. Chemistry: usnic acid and zeorin.

Apothecia c. $1 \mathrm{~mm}$ diam., $0.3-0.5(-0.7) \mathrm{mm}$ when young, and up to $1.5(-2.3)$ $\mathrm{mm}, 280-500 \mathrm{~mm}$ thick. Disc flat, in larger apothecia of ten convex, orange- to reddish brown, castaneous or very dark reddish brown, glossy. Margin prominent, thin, black or darkrown, glossy.

Epithecium diffusely orange-brown to brown, 10-20 $\mu$ m thick. Hymenium 100-180 $\mu \mathrm{m}$ high, often $I+$ blue in its basal part and in the asci, or I -. Excipulum brown, paler in the medullary excipulum, with or without darkbrown subhypothecium, K -. Apothecium base 230-460 $\mu$ m wide. Apothecium chemistry: unknown substances $A$ and C (C usually dominant), sometimes in low concentrations or probably absent. Crystals of Calcium Oxalate sometimes present in the medullary excipulum, often within the apothecium base.

Spores solitary, bicellular and straight (atrorubicans-type, p. 45 Fig. 6 B), 60-120(-140) $\times 20-40(-45) \mu \mathrm{m}$. Spore wall c. $2 \mu \mathrm{m}$ thick. Epispore c. $0.5 \mu \mathrm{m}$ thick, smooth.

Pycnidia not studied. 


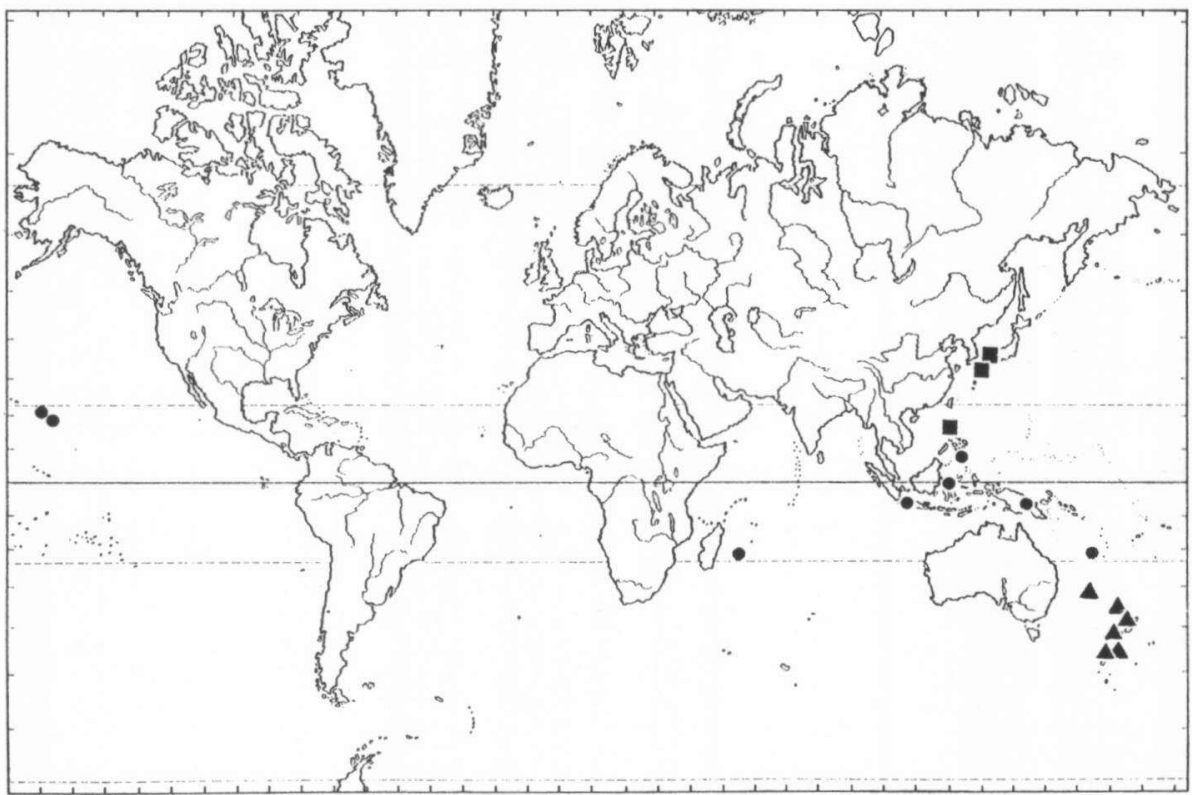

Figure 19. Megalospora atrombicans, distribution. = ssp. atrombicans;

$\Delta$ - ssp. australis; = ssp. sendaiensis.

\section{Distribution and ecology}

The subspecies atrombicans is widely distributed, having been collected in Mauritius, Indonesia, the Philippines, New Guinea, New Caledonia and the Hawaiian islands (Fig. 19). Usually it is found in the mountains, with altitude records ranging from 1000 to $3000 \mathrm{~m}$. The New Caledonian records are from lower elevations, from 300 to $500 \mathrm{~m}$. All collections are on bark. As habitat data for New Caledonia are available: "forest" and "on planted Araucaria cookiz", for Java: "in rain forest on basis of trunk of Ficus robusta, shadowed", for the Philippines: "an Kampherholz-rinden", and for the Hawaiian Islands: "forest" and "on Coprosma".

\section{Remarks}

Subsp. atrombicans differs from both other subspecies in Megalospora atromubicans, ssp. australis and ssp. sendaiensis, by the orange-brown to brown epithecium. The rank of subspecies has been used because only one reliable character was available to distinguish it from the other subspecies. 
The geographical variation of ssp. atrombicans is considerable, as could be expected from the wide range of distribution. Specimens from the Hawaiian Islands have larger spores and a narrower apothecium base, and lack a red-brown tinge in the colour of the disc. A dark subhypothecium and I-negative hymenium are restricted to the New Caledonian plants.

\section{5b. Megalospora atrorubicans ssp. australis ssp. nov.}

type: New Zealand, South Island, Otago, Tautuku Bush, on Weinmania racemosa, J. Scott Thomson ZA 596, T 1675, XII.1935 (CHR, ISO in W)

Diagnosis: Thallus flavescens, crassior, rugulosus vel verrucis $0.2-0.4$ mm latis et $0.2-0.4 \mathrm{~mm}$ altis obtectus, isidiis sorediisque destitutus, acidum usnicum et zeorinum continens. Apothecia c. $1.5 \mathrm{~mm}$ lata et 370-470 $\mu \mathrm{m}$ crassa. Discus planus vel convexus, cervinus vel fuscus, epruinosus, nitidiusculus. Margo prominens, tenuis, disco concolor vel obscurior, epruinosus, nitidiusculus. Epithecium diffusiter olivaceo-fuscum vel fuscum, 7-14 um crassum. Hymenium 130-160 um crassum, I + coerulescens in ascis. Excipulum flavido-rufum vel fuscum, strato tenui rufo in subhymenio provisum, ceteris partibus medullaribus et subhypothecii pallidioribus, $K+$ rubescens vel $K$-negativum. Basis apothecii 280$470 \mu \mathrm{m}$ 1atus. Substantiae ignotae A et C vel A, C, D et E presentes, crystalla calcii-oxalatica in excipulo medullare plerumque provisa. Sporae singulae, bicellulares, rectae (typo "atrorubicans"), magnitudine 75-115 × 30-45 $\mathrm{mm}$, pariete 2-3 $\mu \mathrm{m}$ crasso et septo tenui, episporio $1 \mu \mathrm{m}$ crasso laeve vel raro leviter verrucoso. Sylvarum praecipue Nothofagi solandmi Novae Zelandiae et insulae Lord Howe incola.

\section{Description}

Thallus pale greenish grey, usually with a distinct yellowish tinge, rather thick, rugulose and irregularly cracked, or with more protuberant warts or with c. $0.2 \mathrm{~mm}$ wide and $0.4 \mathrm{~m}$ long papillae, sometimes densily warted with c. 0.2$0.4 \mathrm{mide}$ and equally long warts. Soredia and isidia absent. Chemistry: usnic acid and zeorin.

Apothecia c. $1.5 \mathrm{~mm}$ in diameter, $0.5-0.8 \mathrm{~mm}$ when young, and up to $2.7(-3.1)$ $\mathrm{mm}$, c. $410(370-470) \mu \mathrm{m}$ thick. Disc flat or in larger apothecia slightly convex, occasionally more strongly convex, reddish brown to dark brown, epruinose, 
slightly glossy. Margin prominent, thin, concolorous with the disc or darker, epruinose, slightly glossy.

Epithecium diffusely olivebrown to darkbrown, occasionally more pale, 7-14 $\mu \mathrm{m}$ thick. Hymenium 130-160 $\mathrm{mm}$ high, I + blue in the asci. Excipulum yellowish brown to brown with a thin orange-brown layer in the subhypothecium, $\mathrm{K}+$ red or $\mathrm{K}-$. Apothecium base 280-470 $\mathrm{mm}$ wide. Apothecium chemistry: strain I, unknown substances $A$ and C (C dominant); strain II, unknown substances $A, C, D$ and E. Crystals of Calcium Oxalate mostly present in the medullary excipulum.

Spores solitary, bicellular and straight (atrorubicans-type, p. 45 Fig. 6 B), 75-115 × 30-45 $\mathrm{mm}$. Spore wall 2-3 $\mu \mathrm{m}$ thick. Epispore 1 m thick, usually smooth, sometimes finely warted (Thomson ZA 426, Tucker 19981, Galloway XI.1972).

Pycnidia not observed.

\section{Distribution and ecology}

Megalospora atrombicans ssp. australis is found only in New Zealand and on Lord Howe Island (cf. Fig. 19 on p. 96). In New Zealand it occurs most frequent$1 y$ on the South Island, where it is the commonest Megalospora species in Nothofagus solandri-forests at elevations of $500-1000 \mathrm{~m}$. As phorophytes are recorded Nothofagus, Dacrydium, Phyllocladus and Weinmannia. Sometimes specimens can be found overgrowing mosses, liverworts or epiphyte roots, but generally soft, rather decayed bark is preferred.

\section{Remarks}

Megalospora atrombicans ssp. australis differs from the other subspecies of $M$. atrombicans usually by the larger size of its apothecia and the frequent $\mathrm{K}+$ red-reaction of the excipulum. Moreover the presence of unknown substances $D$ and E and of a warted epispore is within Megalospora atrombicans restricted to ssp. australis, although it is not frequent here. From ssp. atrombicans, whose distribution range borders that of ssp. australis, it differs clearly by the olivebrown to darkbrown epithecium, and ssp. sendaiensis differs constantly by the soon convex apothecia.

The specimens from Lord Howe Island deviate somewhat by their small apothecia, low hymenium, dominance of substance $A$ in the excipulum and more greenish colour of the epithecium. In the former three characters they come close to ssp. atromibicans.

Megalospora gompholoma is in New Zealand the species with the strongest resemblance to ssp. oustralis, by the presence of atrorubicans-type spores. How- 
ever it shows some clear differences: presence of pannarin instead of usnic acid in the thallus; apothecial disc pruinose, at least in young apothecia, and not glossy. Substances $\mathrm{D}$ and $\mathrm{E}$ and a warted epispore are always present in $M$. gompholoma but rare in ssp. australis.

It is remarkable that Megalospora atrombicans ssp. australis has been collected only rarely in the last century, in contrast with other common Megalospora species in New Zealand, such as $M$. gompholoma and $M$. compylospora. By far most collections are from the last decades, and only a single collection (Becket 147) dates back from 1869. In recent times it has been found even in the vicinity of Wellington, from where se many last century collections originate and where Knight payed much attention to the lichen flora.

Its late discovery probably has caused that so far no literature records for ssp. australis exist. Herbarium records have been named incorrectly $M$. sulphurata, M. sulphurata var. campylospora, $M$. marginiflexa and $M$. versicolor.

5c. Megalospora atrorubicans ssp. sendaiensis (Räs.) comb. nov. (P1. 1 D)

basionym: Psorothecizon atrombicans var. sendaiensis RAESAENEN, J. Jap. Bot. 16: 151 (1940)

type: Japan, Sendai, ad corticem Cryptomeriae japonicae, Yasuda 517 (not seen) synonyms :

Megalospora atrombicans var. sendaiensis (RAES.) GRETZ., Bul. Grad. Bot. Muz. Bot. Univ. Cluj. 21: 139 (1941) (not seen).

Lecidea (Psorotheciron) submarginiflexa VAINIo, Bot. Mag. (Tokyo) 25: 67 (1921) SYN. NOV.; - MegaZospora submarginiflexa (VAIN.) A. ZAHLBR., Catal. Lich. Univ. 4: 89 (1927); Psorothecium submarginiflexum (VAIN.) YASUDA, Flechten Japans, p. 26 (1935).

type: Japan, prov. Inaba, Mt. Sankaku, ad corticem Pruni yedoensis, Yasuda 161 (TUR-Vainio 22112).

\section{Description}

Thallus greenish grey, rarely pale yellowish grey or olivaceous, rather thin, rugulose or with nearly granular surface. Isidia absent. Soredia sometimes present, produced by scattered or dense, 10w, 0.2-0.3 $\mathrm{mm}$ wide warts which burst at their top into 20-50 $\mu$ wide soredia, occasionally confluent. Chemistry: usnic acid and zeorin.

Apothecia c. $1.2 \mathrm{~mm}$ diam., 0.4-0.5 mm when young, and up to $2.5 \mathrm{~mm}, 350-470$ $\mu m$ thick. Disc flat in young apothecia, soon more or less convex, black or very dark brown, epruinose, very slightly glossy. Margin prominent only in young 
apothecia, soon excluded, thin, black, epruinose, slightly glossy.

Epithecium diffusely olive-green to olive-brown or darkbrown, occasionally

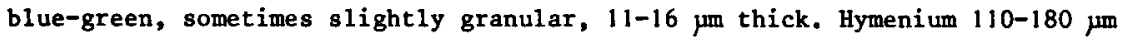
high, I + blue in its basal part and the asci. Excipulum pale brown to brown, more strongly pigmented in the ectal part, after acetone-washing sometimes showing a 50-70 $\mu \mathrm{m}$ thick dark subhypothecium, $\mathrm{K}$ - or $\mathrm{K}+$ pale yellow. Apothecium base 280-550 um wide. Apothecium chemistry: unknown substances A (usually dominant) and $\mathrm{C}$ (sometimes scarse or absent). Crystals of Calcium Oxalate sometimes present in the excipulum or in the apothecium base.

Spores solitary, bicellular and straight (atrorubicans-type, p. 45 Fig. 6 B),

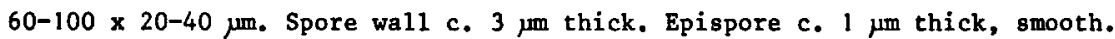

Pycnidia not observed.

\section{Distribution and ecology}

Megalospora atrombicans ssp. sendaiensis is widely distributed in Japan (Fig. 19 on p. 96). Two records are from the Philippines, from pine forest at 1800-2000 $\mathrm{m}$ altitude. Little information is available about the habitat in Japan. In many cases a mountain is mentioned as locality, thus it may be 1imited to higher altitudes. As phorophytes are mentioned "beech" and Cryptomeria japonica, apparently it prefers trees with acid bark. The available specimens are all on bark.

\section{Remarks}

Among the subspecies of Megalospora atrambicans, ssp. sendaiensis is recognisable by the thin and soon-disappearing margin. Moreover the usually olive- to darkbrown epithecium serves to distinguish it from ssp. atrombicans, with which it has a common border.

In the 1iterature ssp. sendaiensis has been referred to as Patellaria atromubicans (MUELLER ARG. 1891), Psorothecium atrombicans (YASUDA 1935), Lecidea marginiflexa (NYLANDER 1890) and Megalospora marginiflexa (ASAHINA 1944 ).

Sorediate plants ("Megalospora submarginiflexa") have been found only in Japan. They have not been treated as a separate taxon because no supporting characters could be found (cf, p. 71). 


\section{Megalospora bartlettii spec. nov.}

Type: New Zealand, North Island, Te Paki Trig Bush, $34^{\circ} 27^{\circ} \mathrm{s}, 173^{\circ} \mathrm{E}$, alt. $800 \mathrm{ft}$. , on Agathis australis 1ignum, Bartlett 19394, 7.IX.1982 (herb. Bartlett)

Diagnosis: Thallus flavescens, tenuior, rugulosus, sorediis destitutus, isidiis c. $0.2 \mathrm{~mm}$ latis et usque ad $0.5 \mathrm{~mm}$ altis deformato-coralloideis provisus, acidum usnicum et zeorinum continens. Apothecia c. $1.5 \mathrm{~mm}$ lata et $0.6 \mathrm{~mm}$ crassa. Discus planus, fuscus, epruinosus, nitidus. Margo prominens, fuscus, epruinosus, nitidus. Epithecium diffusiter rufum, 25-30 $\mathrm{m}$ crassum. Hymenium 140-160 $\mu \mathrm{m}$ crassum, I + laeviter coerulescens tantum in parte basali et circum apicibus ascorum. Excipulum flavo-rufun, crystallis minutis falvescentibus aggregatis in parte superiore ectali provisum, K-negativum. Basis apithecii c. 280 ym latus. Substantiae ignotae $A$ et $C$ presentes, crystalla calcii-oxalatica absentes. Sporae singulae bicellulares rectae (typo "atrorubicans"), magnitudine c. 80-100 × 35-40 $\mathrm{\mu m}$, pariete $2 \mu \mathrm{m}$ crasso, episporio $0.5 \mu \mathrm{m}$ crasso laeve. Sylva Podocarpacearm in Nova Nova Zelandia boreali incola.

\section{Description}

Thallus pale greenish grey, rather thin, rugulose. Soredia absent. Isidia present, stunted-coralloid, c. $0.2 \mathrm{~mm}$ thick and up to $0.5 \mathrm{~mm}$ long. Chemistry: usnic acid and zeorin.

Apothecia c. $1.5 \mathrm{~mm}$ diam., c. $0.7 \mathrm{~mm}$ when young, and up to $2.0 \mathrm{~mm}$, c. $0.6 \mathrm{~mm}$ thick. Disc flat or in the largest apothecia slightly convex, brown, epruinose, slightly glossy. Margin rather prominent, brown, more or less concolorous with the disc, epruinose, slightly glossy.

Epithecium diffusely orange-brown, 25-30 $\mu \mathrm{m}$ thick. Hymenium 140-160 $\mathrm{mm}$ high, I-negative except for a weak blue reaction at the basis of the hymenium and at the ascus tips. Excipulum yellow-brown, with aggregates of fine yellowish crystals of c. $1 \mu \mathrm{m}$ diam. in the upper part of the ectal excipulum, K-. Apothecium basis c. $280 \mu \mathrm{m}$ wide. Apothecium chemistry: unknown substances A and C. Crystals of Calcium Oxalate absent.

Spores solitary, bicellular and straight (atrorubicans-type, p. 45 Fig. $6 \mathrm{~B})$, c. 80-100 × 35-40 $\mathrm{m}$. Spore wal1 $2 \mu \mathrm{m}$ thick. Epispore $0.5 \mu \mathrm{m}$ thick, smooth.

Pycnidia not observed.

\section{Distribution and ecology}

The only available specimens are from the northernmost Podocarpaceae forest in New Zealand (Fig. 20), on the northern part of the North Island at an elevation of c. $250 \mathrm{~m}$. The label mentions Agathis australis lignum as substrate, but 


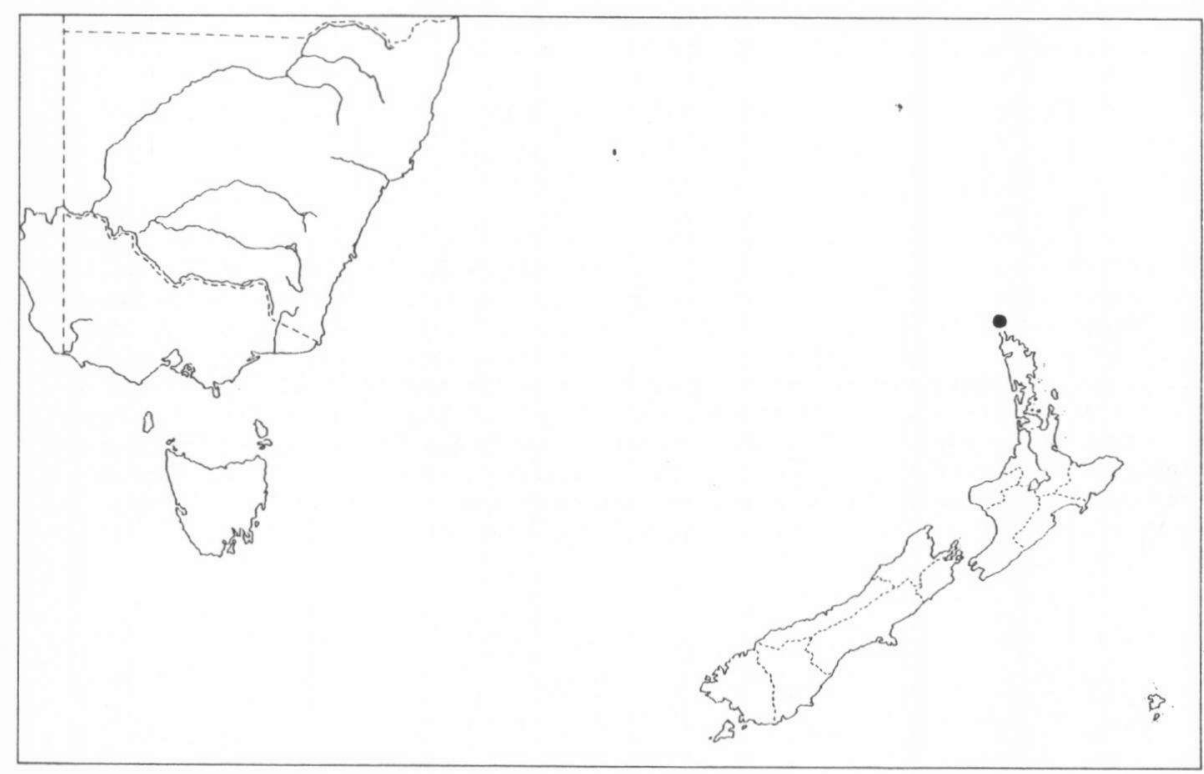

Figure 20. Megalospora bartlettii, distribution.

but both specimens are in fact on bark.

\section{Remarks}

Megalospora bartlettii resembles $M$. sulphureomfa from New Caledonia and Lord Howe Island and $M$. granulans from New Guinea by the combination of atrorubicans-type spores, the absence of darkbrown pigment in the excipulum and the presence of crystal aggregates in the ectal excipulum. However, $M$. sulphureomifa differs by the absence of isidia, the thin apothecia, the thin epithecium, low hymenium and small spores, and $M$. granulans differs by the larger spores and hymenium, the absence of isidia and the pale colour of the apothecial margin. An anomalous specimen of $M$. Butphureorufa from Lord Howe Island (cf. P. 112) differs by the larger spores and hymenium, the absence of isidia and the pale colour of the apothecial margin. 
7a. Megalospora gompholoma (Müll. Arg.) comb. nov. ssp. fuscolineata ssp. nov.

Type: Australia, Victoria, Bloomfield, on bark of tree, Wilson L-3384, 22.IV. 1886 (NSW).

Diagnosis: Thallus albescens, tenuis vel crassior, laevis vel rugulosus, isidiis sorediisque destitutus, pannarinum et zeorinum continens. Apothecia c. $1.5 \mathrm{~mm}$ lata et 330-640 $\mu \mathrm{m}$ crassa. Discus planus vel convexus, fuscus vel niger, pruinosus, opacus. Margo prominens, crassus vel tenuis, fuscus vel niger, epruinosus, nitidiusculus. Epithecium diffusiter olivaceo-fuscum vel fuscum, 7-15 $\mathrm{mm}$ crassum, strato granulare obtectum. Hymenium 120-160 $\mu \mathrm{m}$ crassum, I + coerulescens in ascis. Excipulum flavido-rufum vel fuscum, in parte centrali pallidior, subhypothecio fusco proviso, K + rubescens. Basis apothecii 185-320 $\mu \mathrm{m}$ 1atus. Substantiae ignotae A, D et E presentes, crystalla calcii-oxalatica frequenter in excipulo medullare provisa. Sporae singulae bicellulares rectae (typo "atrorubicans"), magnitudine 77-115 × 25-40 $\mu \mathrm{m}$, pariete $2 \mu \mathrm{m}$ crasso, episporio $1 \mathrm{\mu m}$ crasso verrucoso. Australiae australis et Novae Zelandiae incola.

\section{Description}

Thallus whitis grey, thin or rather thick, smooth or rugulose. Isidia and soredia absent. Chemistry: pannarin and zeorin.

Apothecia c. $1.5 \mathrm{~mm}$ diam., when young $0.5-0.9 \mathrm{~mm}$, and up to (1.2-)2.7 man, 330-640 $\mu$ thick. Disc flat or sometimes markedly convex, darkbrown to black, more or less intensely blue-grey pruinose, dull. Margin prominent, thick or thin, darkbrown to black, epruinose, slightly glossy.

Epithecium diffusely olive-brown to darkbrown, with a yellowish granular

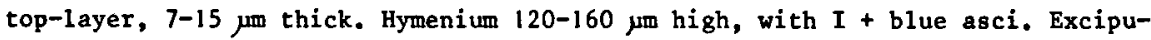
lum yellowish brown to brown, paler in the medullary excipulum, with a darkbrown subhypothecium, $K+$ red. Apothecium basis 185-320 $\mu$ wide. Apothecium chemistry: unknown substances $A$ and, in variable amounts, D and E. Crystals of Calcium Oxalate in the medullary excipulum regularly present.

Spores solitary, bicellular and straight (atrorubicans-type, p. 45 Fig. 6 B), 77-115 $\times 25-40 \mu \mathrm{m}$. Spore wall $2 \mu \mathrm{m}$ thick. Epispore $1 \mu \mathrm{m}$ thick, warted.

Pycnidia not observed.

\section{Distribution and ecology}

Megalospora gompholoma ssp. fuscolineata appears to be restricted mainly to Tasmania and Victoria in Australia, but there is a single, remarkable find from New Zealand (Fig. 21). Habitat information on the labels is scarce. In one case "black spur" is mentioned as phorophyte, in another case "on sappling in riparian woodland". 


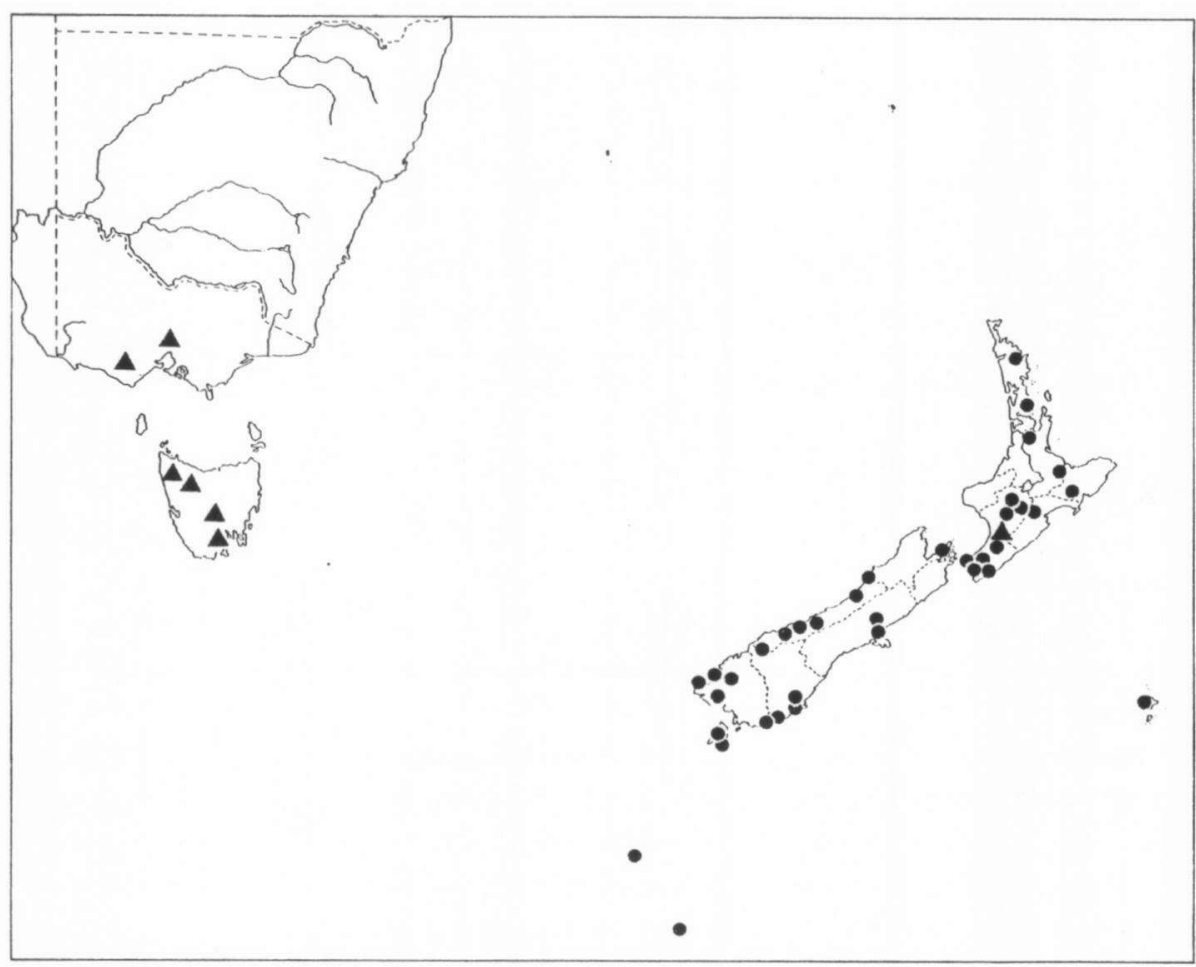

Figure 21. MegaZospora gompholoma, distribution. A = ssp. fuscolineata, - ssp. gomphozoma.

\section{Remarks}

The only reliable character which distinguishes ssp. fuscolineata from ssp. gompholoma is the darkbrown subhypothecium. There are several other characters in which it has a variation pattern different from ssp. gompholoma, but these show large overlaps. Therefore the group has been treated as a separate taxon below species rank. The difference in distribution was the argument to use subspecies rank.

Most collections of this subspecies have been made in the last century, mainly by Archer (Tasmania) and Wilson (Victoria). This suggests that the species has become much more rare in recent times, probably by destruction of its habitat in virgin forest. 
7b. Megalospora gompholoma (Müll. Arg.) comb. nov. ssp. gompholoma (P1. 2 D) basionym: Patellaria gompholoma MUELLER ARG., Flora 62: 5 (1879) (Lich. Beitr. 104)

type: New Zealand, Greymouth, von Müller 21 (G)

synonyms:

Lecidea marginiflexa BABINGT., non HOOK. \& TAYL. (incl. synon.)

? Megalospora marginiflexoides ASAHINA, J. Jap. Bot. 20: 132 (1944).

syntypes: New Zealand, North Island, near Palmerston, Allan s.n., 20.X.1934; ibidem, South Island, Flagstaff Hill near Dunedin, Scott Thomson s,n., 17. IX. 1933 (not seen)

\section{Description}

Thallus pale grey to white, rather thick, rugulose and irregularly cracked to nearly smooth, occasionally more strongly uneven with dense warts of $0.2-0.3 \mathrm{~mm}$ diam. and about as long, of ten overgrowing mosses or epiphytic roots, and then very irregular in shape. Soredia and isidia absent. Chemistry: pannarin and zeorin.

Apothecia c. $1.5 \mathrm{~mm}$ diam., c. $0.8-1.0 \mathrm{~mm}$ when young, and up to $3.5(-4.0) \mathrm{mm}$, c. $500 \mu \mathrm{m}(370-550 \mu \mathrm{m})$ thick. Disc flat or in larger apothecia slightly convex, black or rarely brown to darkbrown, more or less covered with pale grey pruina, at least when young, dull. Margin prominent, thick, black, epruinose or rarely pruinose in a narrow rim around the disc, slightly glossy.

Epithecium diffusely olive-green to olive-brown, sometimes more pale yellowbrown or darkbrown to nearly black, with a yellowish granular top-1ayer, 7-14 $(-24) \mu \mathrm{m}$ thick. Hymenium 120-230 $\mu \mathrm{m}$ high, usually 150-180 $\mu \mathrm{m}, \mathrm{I}+\mathrm{blue}$, at least in its basal parts. Excipulum yellowish brown to brown, with darker ectal layer and thin orange-brown layer in the subhypothecium which disappears by acetone-washing, $\mathrm{K}+$ red. Apothecium basis 230-460 $\mathrm{jm}$ wide. Apothecium chemistry: unknown substances $A, D$ and $E$. Crystals of Calcium Oxalate usually present.

Spores solitary, bicellular and straight (atrorubicans-type, p. 45 Fig. 6 B), 80-165 $\times 25-43 \mu \mathrm{m}$, the smaller ones about two to three times as long as wide, the larger ones about four to five times. Spore wall 1.5-2.5 $\mu \mathrm{m}$ thick. Epispore 0.5-1 $\mu \mathrm{m}$ thick, densely covered with c. $3 \mu \mathrm{m}$ wide and $1 \mu \mathrm{m}$ high warts, rarely smooth (Martin A 554).

Pycnospores c. $3 \times 0.5 \mu \mathrm{m}$. 
Distribution and ecology

Megalospora gompholoma ssp. gompholoma is only known from New Zealand, where it is the most widely distributed species of its genus (Fig. 21). It has been collected all over the North Island and the South Island, and also on the more remote smaller island groups on the New Zealand Plateau, the Stewart Island, the Auckland Islands, Cambell Island and the Chatham Islands. The Campbell Island locality is the southernmost station of the genus Megalospora. Judging from the numbers of collections, the species is more frequent on the South Island than on the North Island. The altitudinal records range from sea level to $1100 \mathrm{~m}$. The most elevated localities are on the North Island. As phorophytes are mentioned: Dacrydium cupressinum, D. intermedium, Griselinia littoralis, Hohneria populnea, Melicytus ramifloms, Metrosideros sp., Nothofagus menziesii and Suttonia australis. This range of species suggests that Megalospora gompholoma ssp. gompholoma occurs in several forest types.

\section{Remarks}

For the differences with its closest resembling species, Megalospora atrorubicans, see under that species. The differentiation from $M$. compyzospora, which at a first glance is very similar, is treated under that species. When typical they show many clear differences, but for nearly all differences one or a few exceptions have been found.

In all literature since BABINGTON (1855) the present species has been referred to as Lecidea marginiflexa or one of its synonyms. However, reexamination of the original material revealed that this name applies to a Megaloblastenia species (cf. p. 92).

\section{Megalospora granulans spec. nov. (P1. 2 A)}

type: Papua New Guinea, Chimbu prov., Pindaunde valley near Mount Wilhelm, in mossy dwarfforest on NE-facing slope along lake Piunde, alt. $3550 \mathrm{~m}$, Sipman 15872B, 14.VIII.1981 (U HOLO, BM, UPNG)

Diagnosis: Thallus flavescens, tenuis, plus minusve rugulosus, isidiis destitutus, soraliis saepe confluentibus sorediis (50-)100-150 $\mathrm{m}$ latis praebentibus obtectus, acidum usnicum et zeorinum continens. Apothecia c. $1.5 \mathrm{~mm}$ lata et 500$650 \mu \mathrm{m}$ crassa. Discus planus, fuscus, epruinosus, haud nitidus. Margo prominens, tenuior, flavidus, epruinosus, opacus. Epithecium diffusiter rufum, 20-25 $\mu \mathrm{m}$ crassum. Hymenium 150-220 $\mu \mathrm{m}$ crassum, I + coerulescens in parte basali. Excipulum flavidum, aggregatis crystallorum minutorum flavescentium in parte superiore 
ectali provisum, $K$-negativum vel $K+$ pallide flavescens. Basis apothecii c. 450 $\mu m$ latus. Substantiae ignotae A et $C$ presentes, crystalla calcii-oxalatica in excipulo medullare provisa. Sporae singulae bicellulares rectae (typo "atrorubicans"), magnitudine 120-170 × 35-45 $\mu \mathrm{m}$, pariete $3 \mu \mathrm{m}$ crasso, episporio $1 \mu \mathrm{m}$ crasso verrucoso. Zonae alpinae Novae Guineae incola.

\section{Description}

Thallus pale yellowish grey, thin, more or less rugulose. Isidia absent. Soredia present, granular, (50-) 100-150 um diam., produced by wartlets which swell and burst into soralia, frequently covering the whole thallus. Chemistry: usnic acid and zeorin.

Apothecia c. 1.5 mm diam., 0.7-0.9 mm when young, and up to $2.5 \mathrm{~mm}, 500-650$ رm thick. Disc flat, darkbrown, hardly glossy. Margin prominent, rather thin, yellowish, dull.

Epithecium diffusely orange-brown, 20-25 $\mu \mathrm{m}$ thick. Hymenium 150-220 $\mu \mathrm{m}$ high, I + blue at base only. Excipulum yellowish, after acetone-washing colourless except for the upper part of the ectal excipulum with fine yellowish crystals of c. $1 \mu \mathrm{m}$ diam, and a c. $70 \mu \mathrm{m}$ thick, grey to pale black subhypothecium, K - or $\mathrm{K}+$ pale yellow. Apothecium base c. $450 \mu \mathrm{m}$ wide. Apothecium chemistry: unknown substances $A$ and $C$. Crystals of Calcium Oxalate always present.

Spores solitary, bicellular and straight (atrorubicans-type, p. 45 Fig. 6 B), 120-170 x 35-45 $\mu \mathrm{m}$. Spore wall $3 \mu \mathrm{m}$ thick. Epispore $1 \mu \mathrm{m}$ thick, warted.

Pycnidia not observed.

\section{Distribution}

The collections, all from Papua New Guinea (Fig. 22), are from the subalpine zone, between c. 3400 and $4000 \mathrm{~m}$ altitude, on Mount Wilhelm and Mount Giluwe. Their habitat is treebark, where they often overgrow mosses. As phorophytes are mentioned: Cyathea and Podocarpus compactus.

\section{Remarks}

Megalospora gramulans is unique in its genus because the thallus is more or less covered with granular soredia. The apothecia resemble perhaps most those of $M$. sulphureorufa, but differ by the larger size and the warted epispore. 


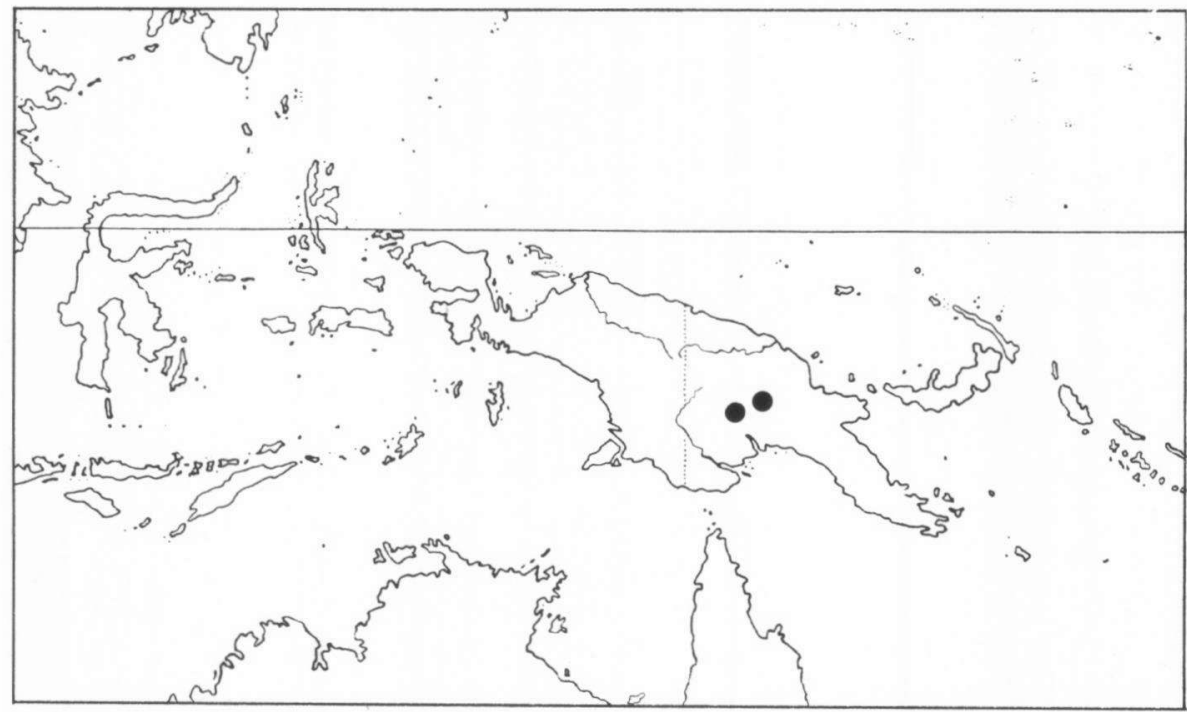

Figure 22. Megalospora granulans, distribution.

9. Megalospora hillii spec. nov.

type: New Caledonia, Yaté, Plaine des Lacs, Rivière des Lacs, La Chute, $166^{\circ} 21^{\prime} 20^{\prime \prime} \mathrm{E}, 22^{\circ} 13^{\prime} 50^{\prime \prime} \mathrm{S}, 700-800 \mathrm{ft}$. , in scrub on lateritic soii, D. J. Hill 11662 (BM)

Diagnosis. Thallus flavescens, tenuis, plus minusve rugulosus, isidiis sorediisque destitutus, acidum usnicum et zeorinum continens. Apothecia c. $1.5 \mathrm{~mm}$ lata et 580-650 $\mu \mathrm{m}$ crassa, obconica. Discus planus, atrofuscus vel niger, epruinosus, nitidus. Margo parum prominens, tenuior, niger, epruinosus, nitidus. Epithecium diffusiter olivaceum vel olivaceo-fuscum ve1 fuscum, 12-20 $\mu \mathrm{m}$ crassum. Hymenium 120-140 $\mu \mathrm{m}$ crassum, I + coerulescens in ascis et plerumque in parte basali hymenii. Excipulum fuscum, in parte centrali plerumque pallidior, subhypothecio rufo tenui provisum, $K$-negativum vel $\mathrm{K}+$ rubescens. Basis apothecii 400-550 $\mu \mathrm{m}$ latus. Substantiae ignotae $A$ et $C$ presentes, crystalla calcii-oxalatica in excipulo medullare nonnumquam provisa. Sporae singulae bicellulares rectae (typo "atrorubicans"), magnitudine $70-100 \times 30-35 \mu \mathrm{m}$, pariete $3 \mu \mathrm{m}$ crasso, episporio $1 \mu \mathrm{m}$ crasso laeve. Novae Caledoniae incola.

\section{Description}

Thallus pale yellowish grey, rather thin, more or less rugulose, little 
cracked. Isidia and soredia absent. Chemistry: usnic acid and zeorin.

Apothecia c. $1.5 \mathrm{~mm}$ diam., $0.8 \mathrm{~mm}$ when young, and up to $3 \mathrm{~mm}$, obconical and much protruding, near the margin 280-460 $\mathrm{m}$ thick, in the centre 580-650 $\mathrm{mm}$. Disc flat, black or dark reddish-brown, epruinose, glossy. Margin little prominent, rather thin, black, epruinose and glossy.

Epithecium diffusely olive-green to olive-brown or brown, or nearly black,

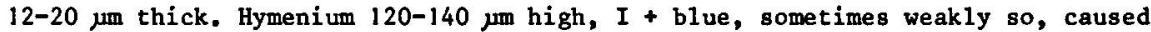
by staining of the asci and usually also the basal part of the hymenium. Excipulum brownish with thin orange-brown layer in the subhypothecium, after acetonewashing with a darkbrown ectal part and pale centre, or uniformly darkbrown (Hill 11656), K -negative or $\mathrm{K}$ + reddish. Apothecium base c. 400-550 um wide, remaining the lowest part of the apothecium. Apothecium chemistry (tested in Hill 11656 only): unknown substances $A$ and C. Crystals of Calcium Oxalate sometimes present.

Spores solitary, bicellular and straight (atrorubicans-type, p. 45 Fig. 6 B),

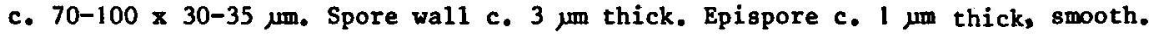
Pycnidia not studied.

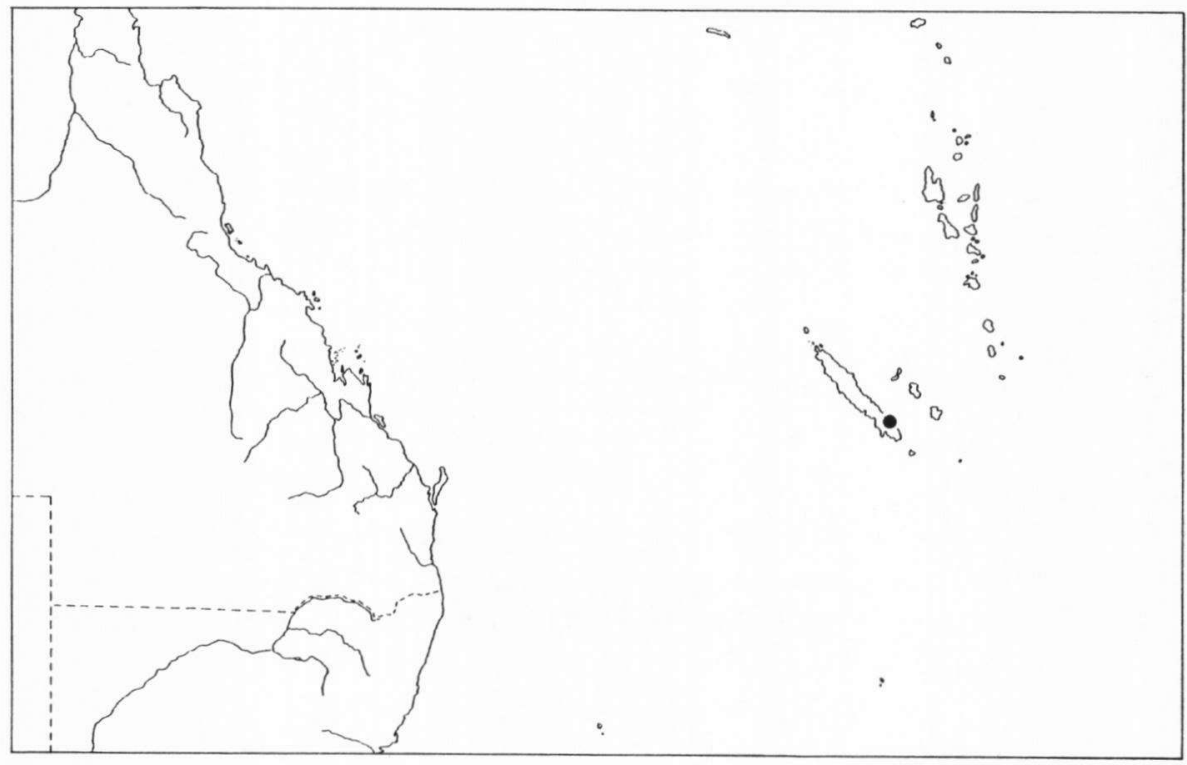

Figure 23. Megalospora hillii, distribution. 
Distribution and ecology

The few collections are all from the southern part of New Caledonia (Fig. 23). Habitat indications include scrub on lateritic soil and rainforest, and an elevation of c. $350 \mathrm{~m}$.

\section{Remarks}

Megalospora hillii is characteristic by its strongly protruding, obconical, b1ack and glossy apothecia. Such apothecia are among the closely related species with straight, bicellular spores found only in $M$. weberi from New Guinea. For the differences with that species see the remarks under its description. The New Caledonian population of $M$. atrombicans ssp. atrombicans resembles the present species closely by its dark-coloured apothecia, but differs by the flat apothecia, the orange-brown to brown epithecium and the usually smaller size of the spores.

One specimen (Hill 11656) differs by the presence of a completely darkbrown excipulum.

10. Megalospora sulphureorufo (Nyl.) Riddle, Bull. Torrey Bot. Club 44: 327 (1917)

basionym: Lecanora sulphureorufa NYLANDER, Bull. Soc. Linn. Normandie, ser. 2, 2: 69 (1868).

type: Nova Caledonia, Lifu, Loyalty, Thiébaut, 1864 (H-Ny1. 24484) LECTOTYPE NOV. NOTE. As lectotype has been choosen the largest specimen from the original material.

synonyms:

Patellaria sulphureorufa (NYL.) MUELLER ARG., Flora 68: 505 (1885) (Lich. Beitr. 942).

\section{Description}

Thallus pale yellowish grey, rather thin, slightly rugulose and little cracked. Soredia and isidia absent. Chemistry: usnic acid and zeorin.

Apothecia c. $1 \mathrm{~mm}$ diam., $0.5-0.7 \mathrm{~mm}$ when young, and up to $1.7(-2.8) \mathrm{mm}$, the largest ones becoming lobed, 275-370 $\mu$ thick. Disc flat, in the largest apothecia convex, orange-brown, epruinose, glossy. Margin prominent, rather thick, yellowish with usually a brown rim around the disc, epruinose, glossy only in brown parts. 
Epithecium diffusely orange-brown to brown, c. $12 \mu \mathrm{m}$ thick. Hymenium 80-120 $\mu m$ high, I - or I + blue caused by staining of the asci and sometimes also the basal part of the hymenium. Excipulum yellowish, after acetone-washing completely pale with only a yellowish, granular substance left in the ectal excipulum, sometimes with algal cells in the medullary excipulum, $K+$ pale yellow. Apothecium base c. $400 \mu$ wide. Apothecium chemistry (tested in Hill 14043 on1y): traces of unknown substances $A$ and $C$ (C dominant). Crystals of Calcium Oxalate usually present, mainly in the ectal excipulum.

Spores solitary, bicellular and straight (atrorubicans-type, p. 45 Fig. 6 B), 55-75 $\times$ 20-28 $\mu \mathrm{m}$. Spore wall $1.5 \mu \mathrm{m}$ thick. Epispore $1 \mu \mathrm{m}$ thick, smooth.

Pycnidia not observed.

Distribution and ecology

The present species has been found on New Caledonia and some nearby islands, Iles Loyautê and Ile des Pins (Fig. 24). An uncertain record exists from Lord Howe Island. Altitude records range from 300 to $500 \mathrm{~m}$. As habitat are mentioned "rain forest" and "forest". All specimens are on bark.

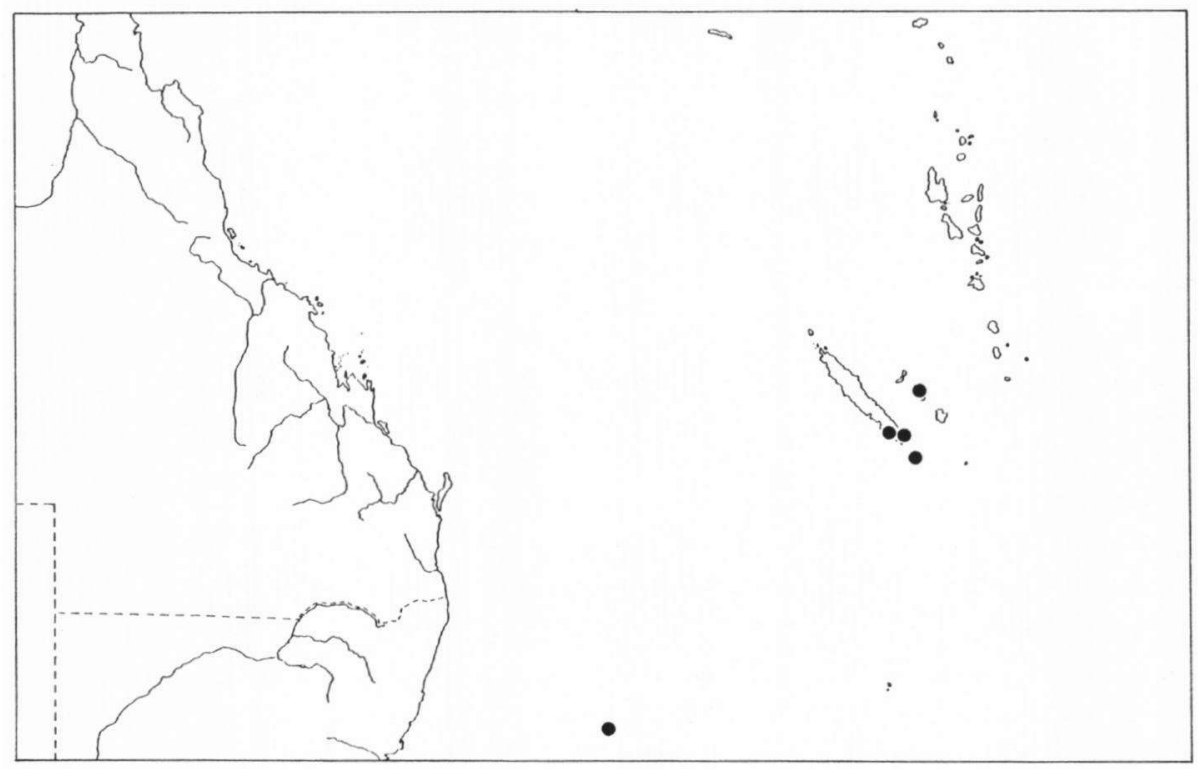

Figure 24. Megalospora sulphureorufa, distribution. 
Remarks

Megalospora sulphureorufa is conspicuous because of its lecanorine appearence. This is, however, not caused by the presence of algae in the apothecial margin, for they are only occasionally present. It is probably caused by the presence in the ectal excipulum of a yellow, granular substance, which also forms an important distinguishing feature with other Megalospora-species with atrorubicans-type spores. Among these species only $M$. bartlettii and M. granulans contain a comparable substance in the ectal excipulum. These species differ from $M$. oulphureomufa by the presence of isidia or soredia and by their larger spores.

A strong resemblance, also in name, exists with Lecania sulphureofusca, which has been confused with it by RIDDLE (1917). For the differences see p. 60 sub III, where the generic differences between Lecania sulphureofusca and Megalospora are given.

A remarkable specimen with a strong resemblance to Megalospora sulphureomufa originates from Lord Howe Island (Watts s.n.). However, it differs considerably by its dimensions: hymenium $250 \mu \mathrm{m}$ high, spores c. $140 \times 45 \mu \mathrm{m}$. In this respect it agrees more with $M$. gronulans from New Guinea. It is provisionally included in $M$. sulphureorufa, but a definitive decision on its taxonomic status has to be postponed until more material is available. Its dimensions are not included in the description.

\section{Megalospora weberi spec. nov.}

type: Papua New Guinea, prov. Chimbu, Pindaunde valley near Mount Wilhelm, in light, stunted forest on SW-facing slope above lake Aunde, alt. $3700 \mathrm{~m}$, H. Sipman 15930 (U HOLOTYPE, BM, UPNG).

Diagnosis: Thallus flavescens, tenuior, plus minusve rugulosus, isidiis et sorediis destitutus, acidum usnicum et zeorinum continens. Apothecia c. $1.5 \mathrm{~mm}$ lata et 650-750 um crassa, obconica. Discus planus, niger, epruinosus, nitidus. Epithecium cyaneum, diffusum, c. 10-20 $\mu \mathrm{m}$ crassum. Hymenium 180-230 $\mu \mathrm{m}$ crassum, $I+$ coerulescens in ascis et nonnumquam in parte basali hymenii. Excipulum flavido-rufum, strato rufo tenui in subhypothecio provisum, K-negativum. Basis apothecii 280-370 $\mu \mathrm{m}$ latus. Substantia ignota A presens, crystalla calcii-oxalatica in excipulo medullare nonnumquam provisa. Sporae singulae bicellulares rectae (typo "atrorubicans"), magnitudine (125-)140-160 x (35-)45-50 $\mu \mathrm{m}$, pariete c. $2 \mu \mathrm{m}$ crasso, episporio c. $1 \mu \mathrm{m}$ crasso laeve. Zonae subalpinae Novae Guineae incola. 


\section{Description}

Thallus pale yellowish grey, rather thin, more or less rugulose. Isidia and soredia absent. Chemistry: usnic acid and zeorin.

Apothecia c. $1.5 \mathrm{~mm}$ diam., 0.7-0.8 mm when young, and up to $3.5 \mathrm{~mm}$, obconical and much protruding, 650-750 $\mathrm{mm}$ thick. Disc flat or in the largest apothecia more or less convex, black, epruinose and glossy. Margin prominent, rather thin, black, epruinose and glossy.

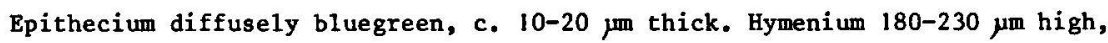
I + blue caused by staining of the asci and sometimes also the basal part of the hymenium. Excipulum yellow-brown with a thin orange-brown layer in the subhypothecium, after acetone-washing with a brown ectal excipulum and pale internal parts, K -. Apothecium base 280-370 $\mathrm{m}$ wide, remaining the lowest part of the apothecium. Apothecium chemistry: unknown substance A. Crystals of Calcium Oxalate sometimes present.

Spores solitary, bicellular and straight (atrorubicans-type, p. 45 Fig. 8 B), (125-) 140-160 x (35-)45-50 $\mu \mathrm{m}$. Spore wall c. $2 \mu \mathrm{m}$ thick. Epispore c. $1 \mu \mathrm{m}$ thick, smooth.

Pycnidia not observed.

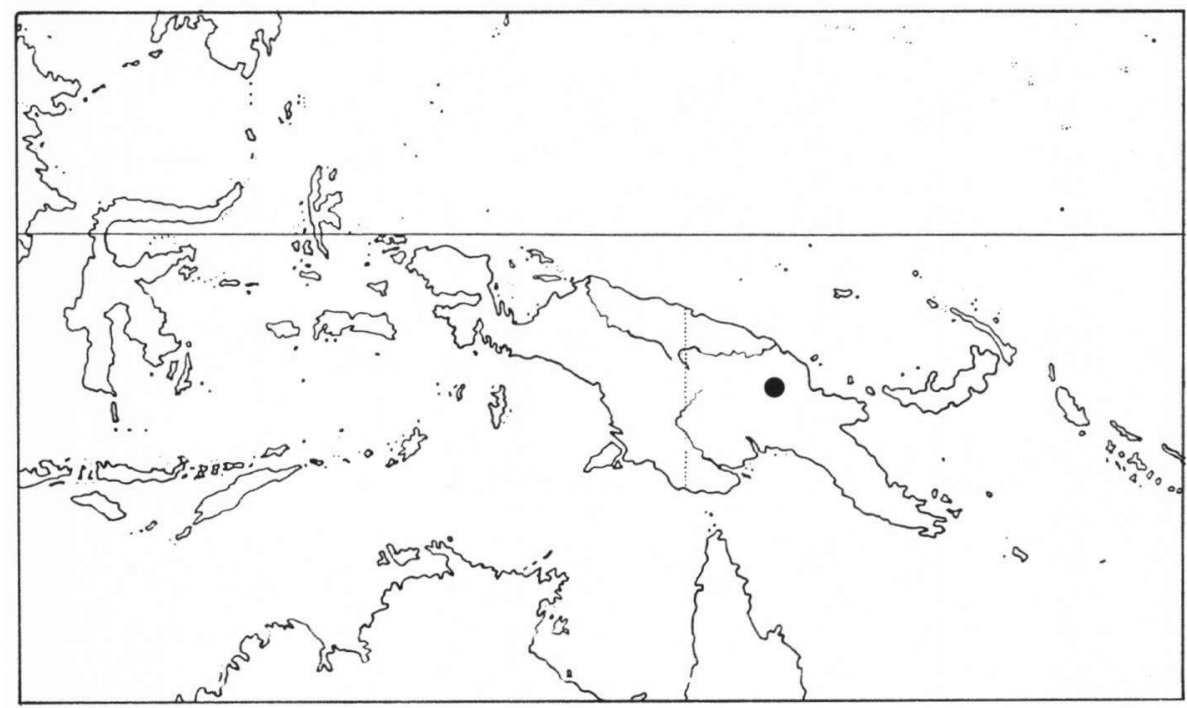

Figure 25. Megalospora weberi, distribution. 
Distribution and ecology

Megalospora weberi has been found so far only on Mount Wilhe1m, Papua New Guinea (Fig. 25), between 3550 and $4000 \mathrm{~m}$ altitude, in subalpine woodland. All collections were growing over mosses and liverworts on treetrunks in well-illuminated places.

\section{Remarks}

Megatospora weberi is well characterised by the obconical apothecia, a character which is among the Megalospora-species with atrorubicans-type spores shown only by $M$. hillii. This species, however, differs clearly by its lower hymenium and smaller spores. Moreover it shows differences in apothecium chemistry and in epithecium colour.

12. Megalospora campylospora (Stirt.) comb. nov.

basionym: Lecidea compyZospora STIRTON, Transact. Proc. New Zealand Inst. 6: 238 (1873).

type: New Zealand, Kaka Hil1, J. Buchanan 11, December 1871 (WELT)

NOTE. The type specimen is selected in accordance with the first description (STIRTON 1873), where the species is stated to originate from: "bark of trees, Kaka Hill, Wellington". Later STIRTON (1875) stated it as: "ad cortices, praecipue vetustos, prope Wellington frequens, alt. 400 metrorum". Thus no collection number is given. Among the Buchanan collections of the present species there are two stated to be from Kaka Hill. One bears the inscriptions "Lecidea campy Zospora spec. nov." and "Dec. /71". This is apparently the original specimen studied by STIRTON. It is in part mixed with $\mathrm{nr}$. 167, stated to contain the spematogonia of $L$. compyzospora. The second specimen bears the date "Aug. 1873", thus it is unlikely that this has been used for the description of a species which appeared in 1873.

synonyms:

Megalospora eulphurata var. compylospora (STIRTON) A. ZAHLBR., Catal. Lich. Univ. 4: 90 (1927).

Lecidea (Catizlaria) clathrata KNIGHT, Trans. Proc. New Zealand Inst. 15: 350351 (1883).

type: New Zealand, C. Knight, recd, $11 / 83$ ( $K$ in BM, ISO in W) LECTOTYPE NOV. NOTE. KNIGHT (1883) in the original publication does not give any locality or other specimen indication, he gives only a habitat indication: "ad arborum cortices". There are several collections available of Megalospora campylospora 
made by him, but none bears any indication which makes it more 1ikely that Knight has used it for his description or not. Therefore the selection of a lectotype among this material has been based only on the fact that it is well developed and that it has a duplicate in another herbarium. The label of the lectotype bears the indication "recd. 11/83" which suggests that the specimen was perhaps sent as an example of the new species.

Lecidea taitensis *epiglauca NYLANDER, Lich. Nov. Zeland., p. 87 (1888); Patelzaria sulphurata var. epiglauca (NYL.) MUELLER ARG., Bull. Herb. Boissier 2, append. 1: 64 (1894); - Psorothecium taitense *Ps. epiglaucum (NYL.) He11BOM, Bih. Kgl. Svenska Vetensk.-Akad. Hand1. 21, 3, no. 13: 97 (1896); - Psorothecium taitense var. ebialaucum (NYL.) A. ZAHLBR., Ann. Mycol. 2: 270 (1904). type: New Zealand, Knight 79a, 1867 (N-Ny1. 18175, ISO in WELT-h. Knight).

NOTE. In the first description (NYLANDER 1888) the only reference to a type specimen is the indication: "ad Kn. 1867". In Nylander"s herbarium (H-Ny1.) there is only one Knight collection of Megalospora compylospora, which bears both the epithet epiglauca and the year 1867, thus this is considered to be the type specimen here.

MegaZospora aZZanii A. ZAHLBR., Denkschr. Akad. Wiss. Wien, math.-naturw. K1., C IV: 315 (1941) SYN. NOV.

type: New Zealand, Chelsea, near Auckland, beech forest, on Suttonia custralis, H. H. Allan ZA417, I. 1932 (W, ISO in CHR).

NOTE. The spore size appeared to be slightly larger than given in the original description, viz. 45-55 x 20-25 $\mu \mathrm{m}$. Thus the type specimen falls clearly within the range of variation of Megalospora campy Zospora.

\section{Description}

Thallus pale greyish white, rather thick, more or less rugulose and irregularly cracked. Isidia and soredia absent, or (in the Tasmanian specimen) thallus diffusely covered by c. 50-100 $\mathrm{mm}$ large granular soredia. Chemistry: pannarin and zeorin.

Apothecia c. 1.7-2.5 mm diam., 1.0-1.5 mm when young, and up to $4.4 \mathrm{~mm}$, 460-650 $\mu \mathrm{m}$ thick. Disc flat or in very large apothecia slightly convex, pale brown-pruinose or sometimes bluish-white-pruinose or nearly black, dull. Margin prominent, usually thick, blackish brown, occasionally somewhat greyish-pruinose, slightly glossy.

Epithecium diffusely olive- or orange-brown with a yellowish granular top-

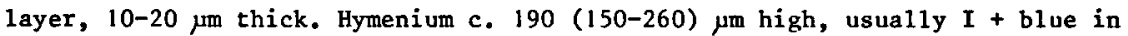
the asci and the basal part of the hymenium. Excipulum yellowish or olivaceous brown to brown, with darker ectal layer and subhypothecium, rarely with thin orange-brown layer in the subhypothecium (Martin 246, 300, s.n. and Thomson

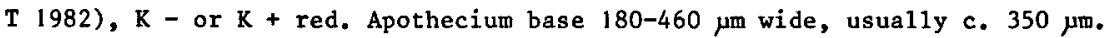
Apothecium chemistry: strain I, unknown substances A and C (C usually dominant); strain II, unknown substances A, C, D and E. Crystals of Calcium Oxalate usu- 
ally present in the medullary excipulum.

Spores (1-)2-6 per ascus, bicellular, more or less curved (sulphurata-type, p. 45 Fig. $6 \mathrm{~A}), 45-85 \times 19-40 \mu \mathrm{m}$, less curved and larger when with few in the ascus, smaller and more strongly curved when with about six in the ascus. Spore wall 2-2.5 $\mu \mathrm{m}$ thick. Epispore $1 \mu \mathrm{m}$ thick, warted (warts c. $2 \mu \mathrm{m}$ wide and $0.5 \mu \mathrm{m}$ high).

Pycnospores bacilliform, c. $4 \times 0.6 \mu \mathrm{m}$.

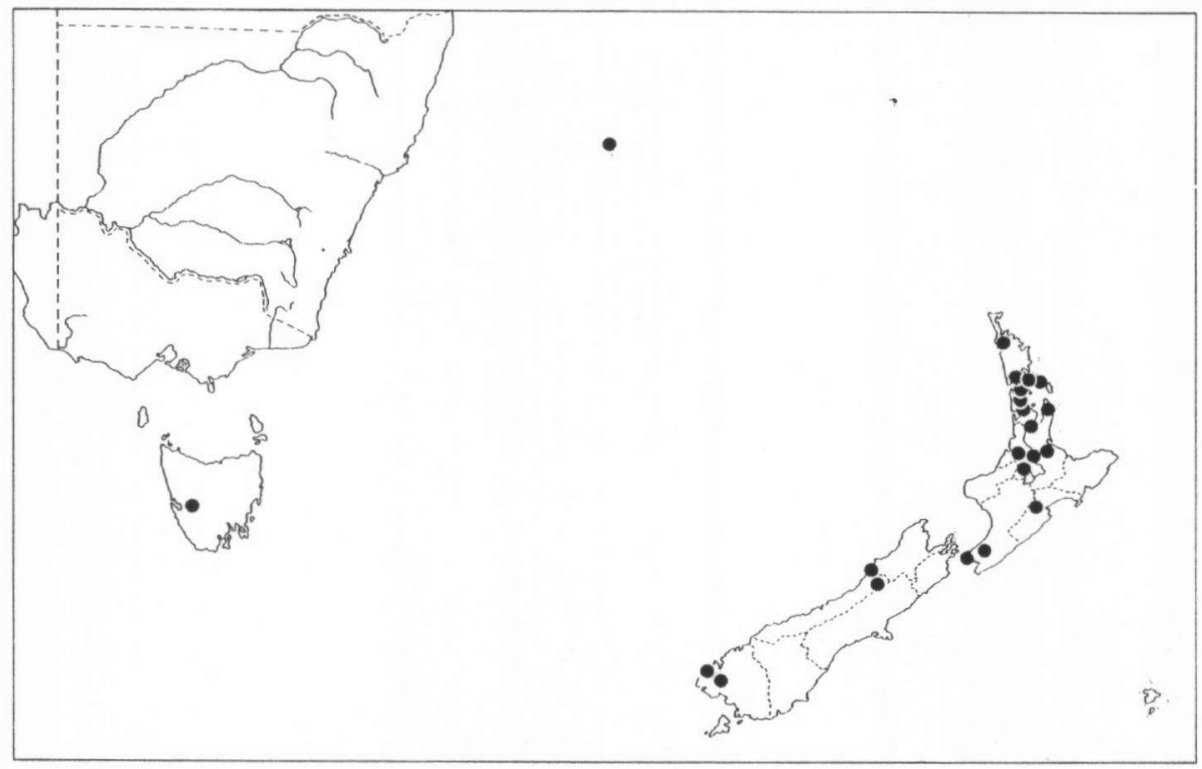

Figure 26. Megalospora compylospora, distribution.

Distribution and ecology

Megalospora campylospora is known from New Zealand, Tasmania and Lord Howe Island. Most specimens are from New Zealand, where the species occurs on both the North Island and the South Island, but is apparently more common in the north. According to the labels it has been found in beech forest and as phorophytes are mentioned Agathis australis, Beilschmidia taraire, Dacrydium kirkii, Nothofagus menziesii, Podocarpus hallii, Phyllocladus trichomonoides and Suttonia austratis. Stirton (1875) mentions it from old trees. The scarce altitude records range from 100 to $500 \mathrm{~m}$ on the North Island and from 500 to $1000 \mathrm{~m}$ on the South Island. 
Remarks

Previous authors (NYLANDER 1888, MUELLER ARG. 1894, HELLBOM 1896 and ZAHLBRUCKNER 1904, 1941) included the present species as an infraspecific taxon in Megalospora sulphurata. However, the present study has revealed several clear differences: 1. presence of pannarin; 2. warted epispore; 3. pruinose disc. By the presence of pannarin $M$. compylospora differs from all other species with sulphurata-type spores. From the other New Zealand species in this group, $M$. knightii and $M$. subtuberculosa, it differs moreover by its generally larger spores and its epithecium colour.

More resemblance, at least superficially, exists with $M$. gompholoma, which on a microscopical examination is easily separable by the possession of atrorubicans-type spores. Other differences are the K-reaction of the excipulum, the presence of unknown substances $D$ and $E$, and the presence of a darkbrown subhypothecium. However in a few specimens one of these differences does not hold.

MUELLER ARG. (1894) was the first who recognised that Lecidea campylospora, $L$. clathrata and $L$. taitensis *epiglauca belong to the same taxon.

The occurence of unknown substances D and $B$ (strain II) is limited to a small number of specimens from all over New Zealand: e.g. on the North Island from Rapier-Taikape road (Bartlett 16675) and Tararua Range (E. Chamberlain $v$ 124), and on the South Island from Otira (Sipman 16777, 16781) and Dusky Sound (D. Galloway, 19.II. 1969). In the presence of substances D and E they resemble $M$. gomphozoma.

The only specimen from Tasmania is also the only sorediate one. It would be of interest. to know whether the presence of soredia is a constant character of the Australian representatives of $M$. compylospora.

Two specimens from Lord Howe island have been included here provisionally. They differ by the dominance of unknown substance $A$ in the apothecia and the rather low hymenium.

13. Megalospora knightii spec. nov.

type: New Zealand, North Island, Auckland prov., Orewa, on Pseudopanax crassifolius, J. Bartlett 16638a, 16.VII.1981 (U, ISO in hb. Bartlett).

Diagnosis: Thallus flavescens, crassior, verrucis $0.2-0.3(-0.5)$ mm latis et usque ad $0.5 \mathrm{~mm}$ altis nonnumquam in soraliis $0.2-1.0 \mathrm{~mm}$ latis (sorediis 15-35 Im crassis) terminantibus obtectus, acidum usnicum et zeorinum continens. Apo- 
thecia c. $2 \mathrm{~mm}$ lata et $600 \mu \mathrm{m}$ crassa. Discus persistenter planus vel deinde convexus, fuscus, nonnumquam leviter pruinosus, opacus. Margo prominens, crassus, pallido-fuscus vel flavidus, raro niger, epruinosus, opacus. Epithecium rufum vel cervinum, crystallis hyalinis c. $2 \mu \mathrm{m}$ latis in strato c. $25 \mu \mathrm{m}$ crasso nonnumquam $70 \mu$ crasso $K$ + flavescentibus provisum. Hymenium 180-250 رm crassum, $I+$ coerulescens in parte basali hymenii et in ascis, vel I-negativum. Excipulum flavidum vel fuscum, in parte centrali pallidior, nonnumquam subhypothecio nigro-fusca provisum, $K+f l$ avescens vel $K$-negativum. Basis apothecii $c .400-$ $450 \mu \mathrm{m}$ latu8. Substantiae ignotae A, B, C, D et E presentes in quantitatibus variantibus, crystalla calcii-oxalatica frequenter provisa. Sporae plerumque sexternae usque ad octonae, bicellulares, laeviter curvatae (typo "sulphurata"),

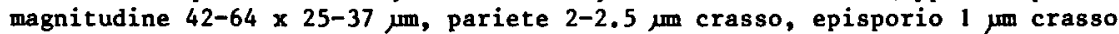
verrucoso. Insulae Septentrionalis Novae Zelandiae incola.

\section{Description}

Thallus yellowish, rather thick, with scattered to crowded, $0.2-0.3(-0.5)$ mm wide warts which remain in part low, in part become papillate and to c. $0.5 \mathrm{~mm}$ high. Isidia absent. Soralia usually present, sma11, c. 0.2-1.0 mm wide, mostly on top of the thallus warts, with 15-35 $\mu \mathrm{m}$ wide soredia, in old herbarium specimens more or less concealed by a weft of fine bluish needle-1ike crystals. Chemistry: usnic acid and zeorin.

Apothecia c. 1.5-2.5 mm diam., 0.8-1.2 mm when young, and up to $3.6 \mathrm{~mm}, \mathrm{c}$. $600 \mu \mathrm{m}$ thick. Disc flat, in the largest apothecia sometimes convex, brown, sometimes slightly pruinose, dull, Margin prominent, thick, pale brown to yellowish, sometimes black (Knight s.n.), epruinose, dull.

Epithecium diffusely orange- to castaneous brown and with numerous crystals in a c. $25 \mu \mathrm{m}$ thick layer; these crystals hyaline, c. $2 \mu \mathrm{m}$ wide, occasionally to $15 \mu \mathrm{m}$ wide, penetrating into the hymenium in tongues of up to $70 \mu \mathrm{ml}$ long, producing a yellow color upon application of K-solution. Hymenium 180-250 $\mu \mathrm{m}$ high, I + blue in its basal part and/or in the asci, or I -. Excipulum yellowish or brown, with a brown ectal layer and a pale or darkbrown subhypothecium, $\mathrm{K}+$ yellow or $\mathrm{K}$-. Apothecium base c. 400-450 $\mu \mathrm{m}$ wide. Apothecium chemistry: strain $I$, unknown substances $B$ and traces of $C$ and sometimes $A$ or $D$, rarely with $A, C$, $D$ and E; strain II, unknown substances $A$ and/or C. Crystals of Calcium Oxalate in the medullary excipulum frequently present.

Spores usually 6-8 per ascus, bicellular and slightly curved (sulphuratatype, p. 45 Fig. 6 A), 42-64 $\times 25-37 \mu m$. Spore wall about 2-2.5 $\mu \mathrm{m}$ thick. Epispore $1 \mathrm{\mu m}$ thick, warted.

Pycnidia not observed. 


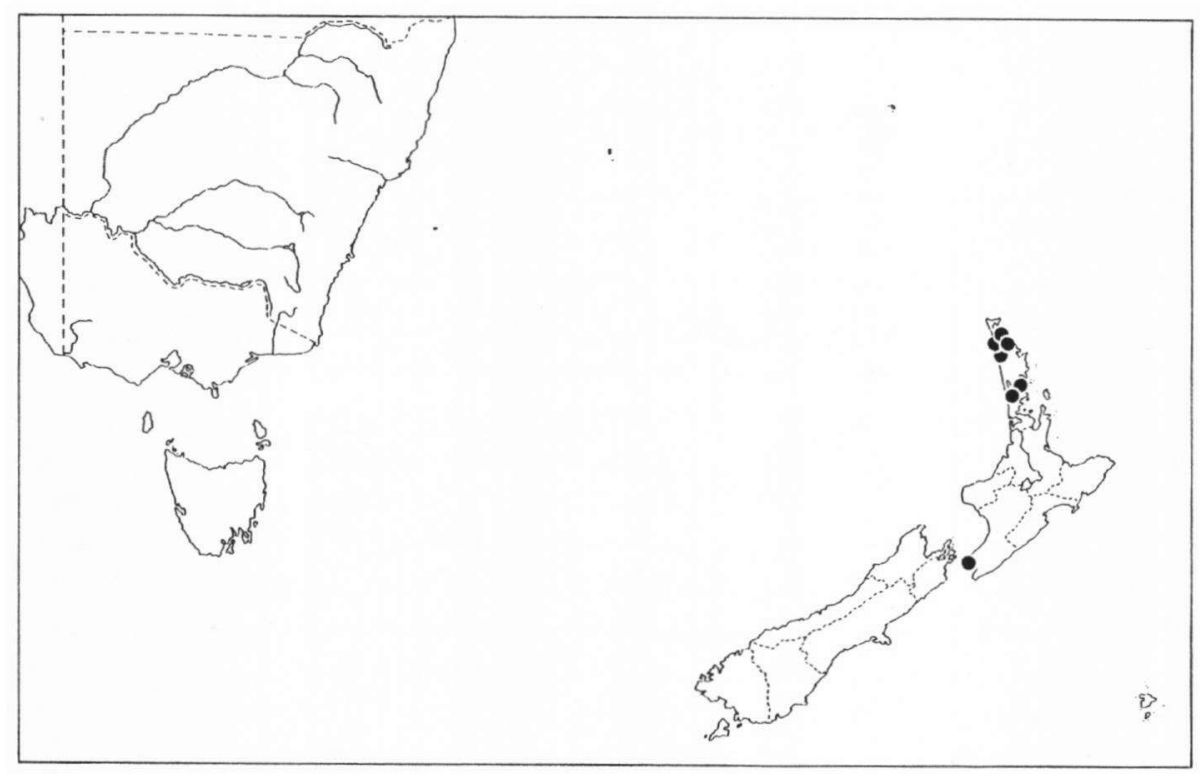

Figure 27. Megalospora knightii, distribution.

Distribution and ecology

The present species in known only from the North Island of New Zealand (Fig. 27), where it is collected from trees in woods. In the available specimens the species was growing on soft, rough bark. As phorophytes are recorded: Agathis australis, Cordyline australis, Myrsine australis, Phylzocladus trichomanoides, Podocarpus fermigineus and Pseudopanax crassifolius. The altitude records range from 100 to $500 \mathrm{~m}$.

\section{Remarks}

Megalospora knightii differs clearly from all other Megalospora species with bicellular spores by the broad layer of coarse crystals in the epithecium which react $K$ + yellow. Moreover it differs from the species with sulphurata-type spores in the following way: $M$. compylospora possesses parietin, $M$. melanodermia has smaller spores, and $M$. sulphurata and $M$. subtuberculosa lack sorediate warts and have a smooth epispore.

The presence or absence of a darkbrown subhypothecium constitutes a rather conspicuous difference. However it has not been given a 
taxonomic status because this difference appears to be uncorrelated with other differences nor with a clearly distinct geographical distribution pattern.

In the past Megalospora knightii has apparently been overlooked by confusion with $M$. sulphurata. This becomes clear from the herbarium labels, which bear the names Lecidea taitensis, Patellaria subvigilans and Psorothecium taitense, all of which are now considered to be synonyms of $M$. sulphurata, see p. 126. They are cited in the literature for New Zealand by e.g. KNIGHT (1875), NYLANDER (1888), MUELLER ARG. (1894), HELLBOM (1896) and ZAHLBRUCKNER (1941). Also the record of Megalospora tuberculosa from New Zealand (BABINGTON 1855, as Biatora pachycarpa), based on a collection of Sinclair, appeared to belong here. Another misidentification of $M$. knightii in herbaria is as $M$. allanii, a synonym of $M$. campy Zospora.

The apothecium chemistry of $M$. knightii is remarkably variable. Many of the possible combinations of substances $A, B, C, D$ and $E$ have been found, but mostly in one or few specimens. The most frequent combination was $B$ with a trace of $C$. Sometimes additional traces of $A$ or $D$ were present in this combination. Because of the generally small amounts of $A, C$ and $D$, they might be present more frequently but in quantities below the detection limit. In one specimen clearly $A, B, C, D$ and $E$ were present all together. This suggests that this is the full chemical spectrum of strain I. In a number of specimens $A$ and/or $C$ were clearly present without a trace of $B$. Therefore these have been treated as a separate strain.

14. Megalospora melanodermia (Müll. Arg.) A. Zahlbr., Catal. Lich. Univ. 4: 89 (1927) (P1. I B).

basionym: Patellaria meZanodermia MUELLER ARG., Nuovo Giorn. Bot. Ital. 23: 392 (1891).

type: Australia, Queensland, Bailey 579 (G)

synonyms:

Psorothecium taitense var. galactocarpum A. ZAHLBR., Ann. Mycol. 2: 270 (1904); Megalospora sulphurata var. galactocarpa (A. ZAHLBR.) A. ZAHLBR., Catal, Lich. Univ. 4: 91 (1927) SYN. NOV.

type: Australia, New South Wales, Stanwell Park, E. Cheel \& L. J, Boorman in A. Zahlbruckner, Lich, Rarior. Exs, 48 (W HOLO, G) 


\section{Description}

Thallus pale greenish or yellowish grey, rather thick, more or less rugulose and irregularly cracked, often overgrowing mosses and very irregular in shape. Isidia and soredia absent. Chemistry: usnic acid and zeorin.

Apothecia c. 1.2-1.5 mm diam., 0.5-0.8 mm when young, and up to 2.1-2.7 mm, 350-560 $\mu \mathrm{m}$ thick. Disc flat, in larger apothecia more or less convex, brown to darkbrown, sometimes epruinose and slightly glossy, but usually more or less covered with dense, white pruina and dull. Margin prominent, rather thick or thin, darkbrown to black, slightly glossy, occasionally adjacent to the disc covered by the same white pruina as the disc.

Epithecium diffusely brown, sometimes with an olivaceous tinge, occasionally olive-green or nearly black, sometimes granular, especially near the surface of the disc, 7-14 $\mu \mathrm{m}$ thick, in lactophenol-cottonblue preparations often with hyaline, elongate or more or less isodiametric crystals of 1-15 $\mu \mathrm{m}$ in length; which penetrate into the hymenium in tongues to $70 \mathrm{\mu m}$ or further, to the base of the hymenium, and are $\mathrm{K}$-. Hymenium 130-180 $\mu \mathrm{m}$ high, I + blue caused by staining of the basal part of the hymenium (sometimes) and the asci. Excipulum yellowish brown to brown, with darker ectal layer, sometimes with a thin orange-brown layer in the subhypothecium or with a darkbrown subhypothecium, $k-$. Apothecium base 260-330 $\mu$ wide. Apothecium chemistry: unknown substances A and C. Crystals of Calcium Oxalate absent.

Spores 3-7 per ascus, bicellular and usually clearly curved (sulphurata-type, p. 45 Fig. 6 A), 30-40(-46) x 18-25 $\mu \mathrm{m}$. Spore wall c. $2.5 \mu \mathrm{m}$ thick. Epispore $1 \mu \mathrm{m}$ thick, usually warted (warts c. $2 \mu \mathrm{m}$ wide and $0.5 \mu \mathrm{m}$ high).

Pycnidia not observed.

Distribution and ecology.

Megalospora melanodermia is known from the easterns parts of the Australian mainland, from central Queensland to New South Wales (Fig. 28). The altitudinal distribution ranges from 100 to $1500 \mathrm{~m}$. In the northern parts of the range mountains seem to be preferred: Mount Mistake, MacPherson Range. As habitat are mentioned: wet sclerophyll forest, secondary rain forest and rain forest. One collection was on sandstone, all others were on bark.

\section{Remarks}

Megalospora melanodermia resembles closely $M$. sulphurata but the latter differs clearly by the larger spores and the absence of white pruina and granules 


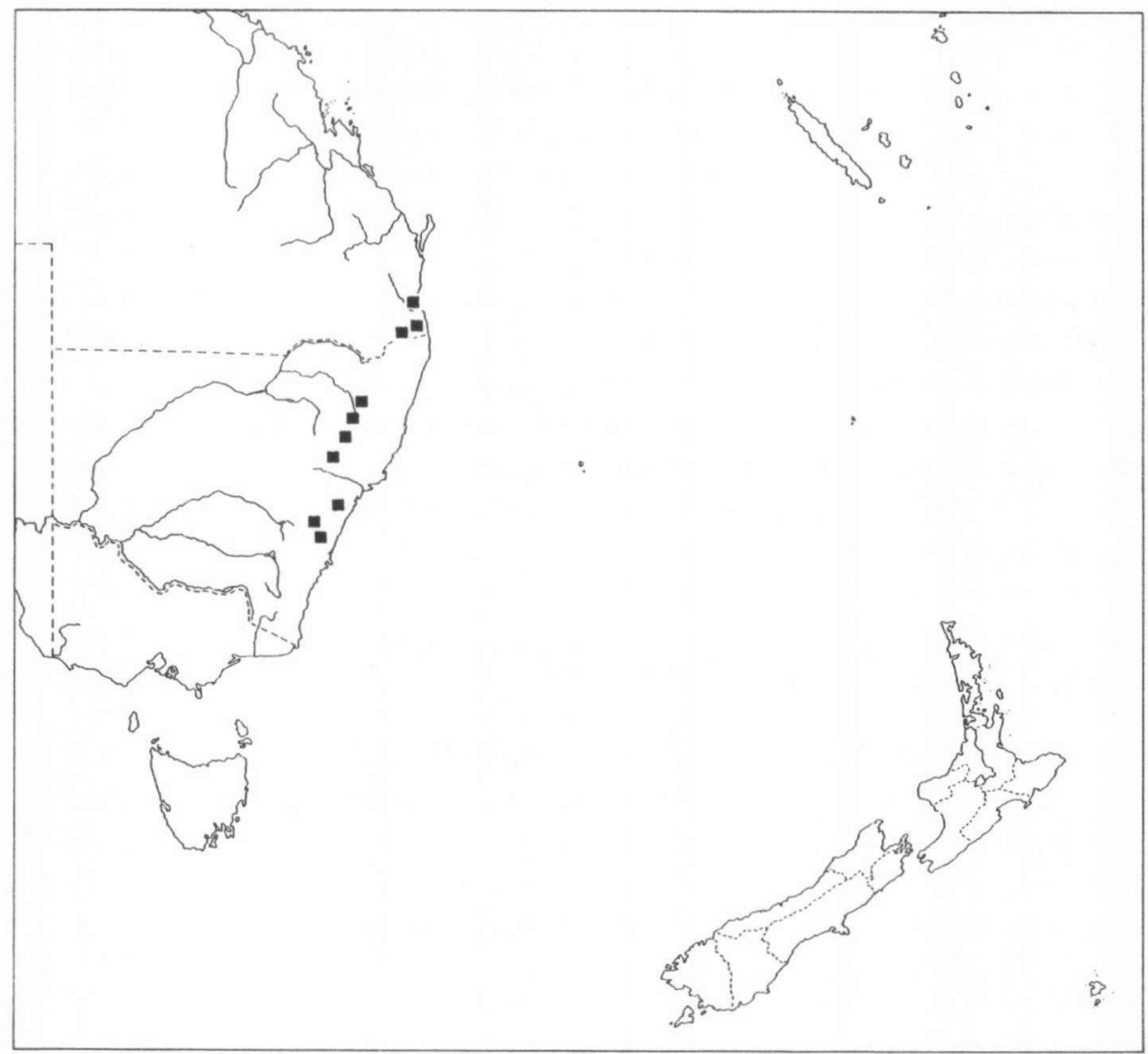

Figure 28. Megalospora meZanodermia, distribution.

or crystals in the epithecium. A considerable similarity exists also with $M$. knightii from New Zealand, which agrees by the rather small spores and the tongues of crystals penetrating the hymenium. However, it differs by the absence of white pruina, the $\mathrm{K}+$ yellow-reaction of the crystals in the epithecium, the orange-brown epithecium colour and the larger spores.

The white pruina of $M$. melonodermia differs from the pruina of e.g. $M$. gompholoma by its occurence in more dense layers, its more whitish colour, and because its occurence is so variable within a single thallus and even a single apothecium (cf. P1. 1 B). The pruina seems to coincide with the presence of 
crystals in the epithecium and hymenium. The apparent variation in pruinosity was the reason to unite the completely epruinose type of Patelzaria melanodermia with the strongly pruinose Psorothecium taitense var, galactocarpum. Moreover both share the very small spores, unique in Megalospora.

The herbarium determinations of the present species show that it has been confused with $M$. campylospora or considered conspecific with $M_{0}$. sulphurata: Patellaria sulphurata var. epiglauca, P. sulphurata, P. taitense, Megalospora sulphurata and Lecidea versicolor. Two collections stated to be of Tasmania, Grose River, bear the inscription "Lichen atro-cinereus", evidently an unpublished name (non Lichen atrocinereus DICKS. 1793 = Rinodina atrocinerea (DICKS.) KOERB.). Moreover the Grose river locality is erroneously stated to be in Tasmania, but is in fact in New South Wales (R. Filson and G. Kantvilas, in litt.).

15. Megalospora subtuberculosa (Knight) stat. nov.

basionym: Lecidea versicolor var. subtuberculosa KNIGHT, Trans. Proc. New Zealand Inst. 7: 358, Tab. 23 Fig. 8 (1874)

type: New Zealand, 4.v.79, herb. Knight, vol. 51, p. 14 (WELT) LECTOTYPE NOV, NOTE. Only two plants have been found with the indication Lecidea versicolor var. subtuberculosa on their label, both in the herbarium of KNIGHT and thus likely to be used by KNIGHT when describing his new variety. From them the specimen with the most apothecia has been selected as lectotype.

synonym:

Megalospora versicolor var. subtuberculosa (KNIGHT) A. ZAHLBR., Catal. Lich. Univ. 4: 93 (1927).

\section{Description}

Thallus yellowish- to greenish grey, thin, nearly smooth or slightly rugulose. Isidia absent. Soralia present, roundish, slightly raised ("subtuberculose"), c. 0.4-1 mm wide, with 20-35(-50) um wide soredia. Chemistry: usnic acid and zeorin.

Apothecia scarce, lacking over large parts of the thallus, c. $1.5-2.2 \mathrm{~mm}$ diam., $0.8 \mathrm{~mm}$ when young, and up to $3.0 \mathrm{~mm}, \mathrm{c}$. 450-550 $\mathrm{mm}$ thick. Disc flat, in the largest apothecia slightly convex, brown to nearly black, epruinose, dull. Margin prominent, rather thick, concolorous with the disc or slightly more darkbrown, epruinose, slightly glossy.

Epithecium diffusely brown, 12-18 $\mu \mathrm{m}$ thick. Hymenium 160-230 $\mu \mathrm{m}$ high, I + 
blue in the asci. Excipulum yellowish to pale brown, after acetone washing pale with a brown ectal layer, occasionally with a brown subhypothecium (Bartlett 16626), K -. Apothecium base c. $370 \mu \mathrm{m}$ wide. Apothecium chemistry: unknown substances $A$ and/or C. Crystals of Calcium Oxalate always present in the medullary excipulum.

Spores (2-)6-8 per ascus, bicellular and slightly curved (sulphurata-type, p. 45 Fig. 6 A), 32-42 $\times 19-25 \mu \mathrm{m}$. Spore wall 1-2 $\mu \mathrm{m}$ thick. Epispore $1 \mu \mathrm{m}$ thick, smooth.

Pycnidia not observed.

Distribution and ecology

Megalospora subtuberculosa is only known from the North Island of New Zealand (Fig. 29). Altitude records range from 100 to $500 \mathrm{~m}$. As phorophytes are mentioned: Coprosma Zucida; Mursine australis and Nikan palm. All specimens are from smooth, thin bark.

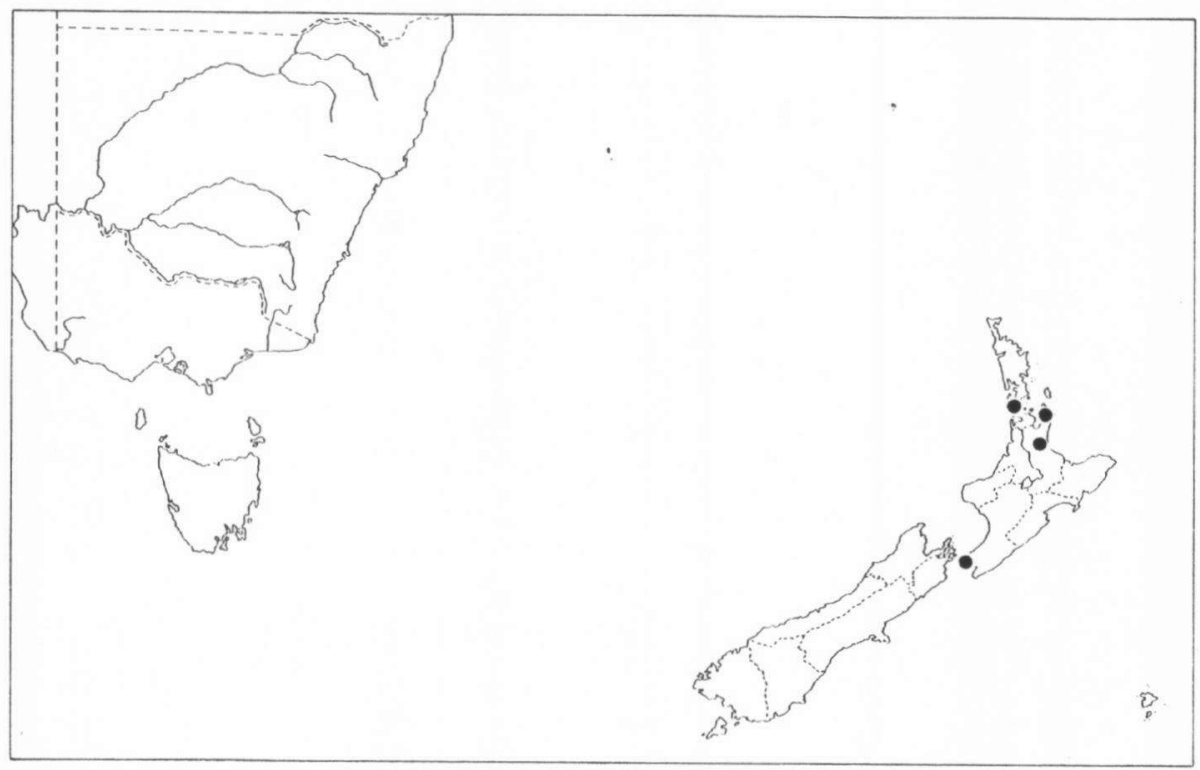

Figure 29. Megalospora subtuberculosa, distribution. 


\section{Remarks}

Megalospora subtuberculosa differs from all other Megalospora species in New Zealand by the very smooth thallus with subtuberculate soralia, and moreover by the following combination of characters: presence of usnic acid; sulphurata-type spores; non-granular epithecium. It resembles $M$. sulphurata closely but differs by the subtuberculate soralia and the very small spores.

The rarity of apothecia on the available specimens suggests that the species may occur more frequently without apothecia, but in such a state it is likely to be underrepresented in the herbaria.

The name "subtuberculosa" probably has been given by its author because of the slightly raised soralia. However, it is remarkable that KNIGHT did not notice the presence of soredia. The attribution to "Lecidea versicolor" was probably based on the very dark apothecia, not unlike those of $M$. sulphurata, with which "Lecidea versicolor" has been confused,

16. Megalospora sulphurata Meyen in MEYEN \& FLOTOW, Nova Acta Acad. Leopold.Carol. 19, Supp1., p. 228 (1843) var.sulphurata (P1. 1 C)

type: Philippines, "Crescit in 1ignis putridis Manillae", F. J. F. Meyen, IX-X. 1841 (G isotype?)

NOTE. The type collection appears to have been destroyed with the fire of the Berlin herbarium in the last worldwar, but a small fragment in Müller's herbarium in $\mathrm{G}$ with indication "Manilla" is probably a fragment of it.

The original description mentions 4-5-celled spores, but according to MUELLER ARG. (1883) the spores are in fact bicellular.

synonyms:

Pate Zlaria sulphurata (MEYEN) MUELLER ARG., Jahrb. Kgl. Bot. Gart. Berlin 2: 316 (1883); - Lecidea sulphurata (MEYEN) WAINIO, Acta Soc. Fauna F1. Fenn. 7(2): 35 (1890); - Psorothecium sulphuratum (MEYEN) A. ZAHLBR., Sitzungsber. K. Akad. Wiss. Wien, math.-naturw. Classe 3, Abt. 1: 396 (1902); - Catillaria sulphurata (MEYEN) WAINIO, Ann. Acad. Sci. Fenn., ser. A, 15, no. 6: 104 (1921).

Megalospora sulphurata var. genuina Riddle, Bull. Torrey Bot. Club 44: 329 (1917) NOM. INVALID.

Catillaria sulphurata var. phaeocheila VAINI0, Annal. Acad. Sci. Fenn., ser. A, 15, no. 6: 104 (1921); - Megalospora sulphurata var. phaeocheila (VAINI0) A. ZAHLBR., Catal. Lich. Univ. 4: 91 (1927).

original material: see type description (specimens seen from $B M, F H$ and $W$ ).

Catillaria sulphurata var. ochrocheila VAINIo, Ann. Acad. Sci. Fenn., ser. A, 15, no. 6: 105 (1921); - Megalospora sulphurata var. ochrocheila (VAINI0) A. 
ZAHLBR., Catal. Lich. Univ. 4: 91 (1927). Original material: see type description (specimens seen from BM, FH, US and $W$ ).

Catillaria sulphurata var. lecanocheila vaINIo, Ann. Acad. Sci. Fenn., ser. A, 15, no. 6: 105 (1921); - Megalospora sulphurata var. Zecanocheila (VAINIO) A. ZAHLBR., Catal. Lich. Univ. 4: 91 (1927).

original material: see type description (specimens seen from BM, FH, US and W).

Biatora taitensis MONTAGNE, Ann. Sci. Nat., Bot., ser. 3, 10: 126 (1848); - Heterothecirm taitense (MONT.) MONTAGNE \& van den BOSCH, apud JUNGHUHN, Plant. Junghuhn., fasc. 4: 462 (1855); - Blastenia taitensis (MONT.) TREVISAN, Linnaea 28: 290 (1856); - Psorothecium taitense (MONT.) MASSALONGO, Atti I. R. Istit. Veneto, ser. 3, 5: 261 (1860); - Lecidea taitensis (MONT.) NYLANDER, Ann. Sci. Nat., Bit., ser. 4, 19: 243 (1863); - Patellaria taitensis (MONT.) MUELLER ARG., Flora 65: 330 (1882); - Megalospora taitensis (MONT.) van OVEREEM-de HAAS, Bull. Jard. Bot. Buitenzorg, ser. 3, 4: 120 (1922). type: Tahiti, J. Lépine 33 ( $P$, iso $H)$

? Lecidea grandis NYLANDER, Mém. Soc. Sci. Cherbourg 5: 122 (1857) NOM. NUD.

Lecidea megacarpa MYLANDER, Ann. Sci. Nat., Bot., ser. 4, 11: 260 (1859); - Psorothecizom megacarpum (NYL.) MASSALONGO, Atti I. R. Istit. Veneto, ser. 3, 5: 261 (1860); - Patellaria megacarpa (NYL.) MUELLER ARG., Flora 65: 488 (1882); - Megalospora megacarpa (NYL.) MALMR, Ark. Bot. 18 (12): 6 (1923); - Patellaria sulphurata var. megacarpa (NYL.) MUELLER ARG., Flora 69: 288 (1886); - Megalospora sulphurata var. megacarpa (NYL.) RIDDLE, Bull. Torrey Bot. Club 44: 329 (1917).

type: "Ad cortices in insula Mauritii, ex hb. cel. Fée" (H iso?)

Lecidea megaspora LEIGHTON, Trans. Linn. Soc. London 27: 173 (1869); - Patellaria megaspora (LEIGHT.) MUELLER ARG., Flora 65: 330 (1882); - Megalospora megaopora (LEIGHT.) A. ZAHLBR., Catal. Lich. Univ. 4: 88 (1927).

type: Sri Lanka, Habgalla, $5000 \mathrm{ft}$. alt., G. H. R. Thwaites (BM)

NOTE. Among the many specimens with Thwaites" name and the indication "Lecidea megaspora" this specimen appears to be intended as the type, because it bears the inscription " $n$. sp." and a remark comparing it with "L. marginiflexa", as in the original description.

Patellaria subvigilans MUELLER ARG., Flora 65: 329 (1882); - Biatorina subvigiZano (MUELl. ARG.) HELLBOM, Bih. Kgl. Svensk. Vetensk.-Akad. Hand1. 21, afd. 3, 13: 109 (1896); - Megalospora subvigilans (MUELL. ARG.) A. ZAHLBR. apud RECHINGER, Denkschr. math.-naturw. Classe K. Akad. Wiss. Wien 81: 251 (1908).

type: "Frequens in insula Java (in hb. saepe cum Patell. taitensi commixta)", Java, 350/37, upper right specimen (G LECTOTYPE NOV, iso L)

NOTE. In the original description no specimen is mentioned, but there is only one packet of Patellamia subvigilans in the herbarium of Müller Arg. in G, bearing the indication "Orig.". It contains a card with seven small fragments, evidently taken from specimens preserved in $L$. The upper left fragment belongs to the collection L 910.201-2892, the upper right one to L 910.201-2891, and the lowest one to $\mathrm{L}$ 910.201-2893. The remaining four fragments are too sma11 or abraded to recognise their origin. Among the three larger fragments the lower one is unsuitable as lectotype because it is aberrant by its pale apothecium margin, which is in contradiction with the original description. The upper left specimen is poor in apothecia, also the fragment in $L$. Therefore the upper right fragment is chosen here as lectotype, with an (larger) isolectotype in L. 
Patellaria pachyloma MUELlER ARG., J. Bot. (Morot) 7: 93 (1893) SYN. Nov.; Megalospora pachyloma (MIJELL. ARG.) A. ZAHLBR, Catal. Lich. Univ. 4: 89 (1927). type: New Caledonia, inter St. Louis et Yatê, Balansa 1896 (G).

Megalospora cumingsiae RIDDLE, Mycologia 4: 129 (1912) SYN. NOV. sype: Jamaica, on bark, Clara E. Cummings 129 (FH).

Megalospora castanocarpa A. L. SMITH, J. Linn. Soc. London, Bot. 46: 76 (1922) type: New Caledonia, Ignambi, 2000-4000 ft., Compton 1738 (BM)

? Megalospora thwaitesii MALME, Ark. Bot. 18 (12): 6 (1923) NOM. NUD.

Megalospora papillifera H. MAGNuSSON, Ark. Bot., ser. 2, III (10): 312 (1955) SYN, NOV.

type: Hawaiian Islands, Kauai, Koloa 1909, Faurie (133) (UPS iso).

Megalospora nipponensis ASAHINA, J. Jap. Bot. 32: 97-98 (1957) SYN, Nov. type: Japan, Akitsugawa, prov. Kii (109), Y. Asahina, 1925 (TNS-Asahina) (not seen, according to the description).

Megalospora vermuculosa MAKHIJA \& NAGARKAR, Curr. Sci. 50: 823 (1981) SYN. NOV. type: India, Tamil Nadu, Nilgiri Hills, Pyakara, in Shola forest, P. G. Patwardhan \& M. B. Nagarkar 73.1272 (AMH)

\section{Description}

Thallus greenish- or yellowish grey to greenish yellow, thick, more or less rugulose, usually little and irregularly cracked, of ten overgrowing mosses or epiphytes and very irregular in shape, occasionally warted or papillose with $0.2-0.5 \mathrm{~mm}$ wide and about equally long papillae. Isidia and soredia usually absent but locally common: Isidia cylindrical to coralloid-branched, 0.2-0.5 mm long and 0.15-0.2 mm wide; soredia 40(-80) $\mu \mathrm{m}$ diam., produced in 0.2-0.4 mm wide soralia which develop on thallus warts and may become to $2 \mathrm{~mm}$ wide or even confluence. Chemistry: usnic acid and zeorin.

Apothecia c. $2 \mathrm{~mm}$ diam., (0.8-) 1.0-1.5 mm when young, and up to $3.5-5.0 \mathrm{~mm}$, (400-) 500-750 m thick. Disc flat, in larger apothecia more or less convex, (red-)brown to darkbrown or black, slightly glossy, epruinose. Margin prominent, thick, yellowish to brown or black, concolorous with the disc or more pale or darker, slightly glossy, epruinose.

Epithecium diffusely orange-brown (to brown), 12-22 $\mu$ m thick. Hymenium c. 150-250 $\mathrm{\mu m}$ high, I + blue in its basal part, sometimes also in the asci, or I -. Excipulum yellow-brown to brown, with or without darker ectal layer, with or without darkbrown or thin orange-brown subhypothecium, $k$ - or $k+$ yellow, rare$1 y K+$ slightly reddish. Apothecium base (280-) 350-550 $\mu$ wide. Apothecium chemistry: strain $I$, unknown substance $A$ and $C$; strain $I I$, unknown substances $A$, $B$ and C. Crystals of Calcium Oxalate in the medullary excipulum of ten present. 
Spores (1-)2-8 per ascus, bicellular and more or less curved, with thick edges around the septa (sulphurata-type, p. $45 \mathrm{Fig} .6 \mathrm{~A}$ ), with isodiametric or elongate, to about twice as long as wide lumina (cf. P1. 19), (45-)50-80(-125) x

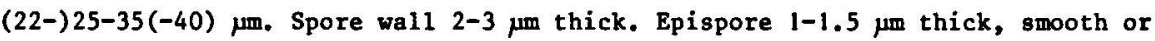
rarely warted (only in Papua New Guinea).

Pycnospores $3.5 \times 0.8 \mu \mathrm{m}$.

\section{Distribution and ecology}

Megalospora sulphurata is one of the most widespread species of its genus. Var. oulphurata has been collected in many countries from New Caledonia to Japan, and from South America and Ascension, over Mauritius and Indonesia to the Hawaiian Islands (Fig. 30). However, its range is largely restricted to the tropics. It is a mountain species, and most collections have been found between 1300 and $2600 \mathrm{~m}$ altitude. Occasionally it descends to $300-400 \mathrm{~m}, \mathrm{e.g}$. on the Philippines, the Hawaiian Islands and Sri Lanka. Its highest records are from $3500 \mathrm{~m}$ on Mount Kinabalu, Sabah, and $3700 \mathrm{~m}$ on Mount Wilhelm, Papua New Guinea. Available habitat data are, for the Hawaiian Islands: "dry upland scrub forest",

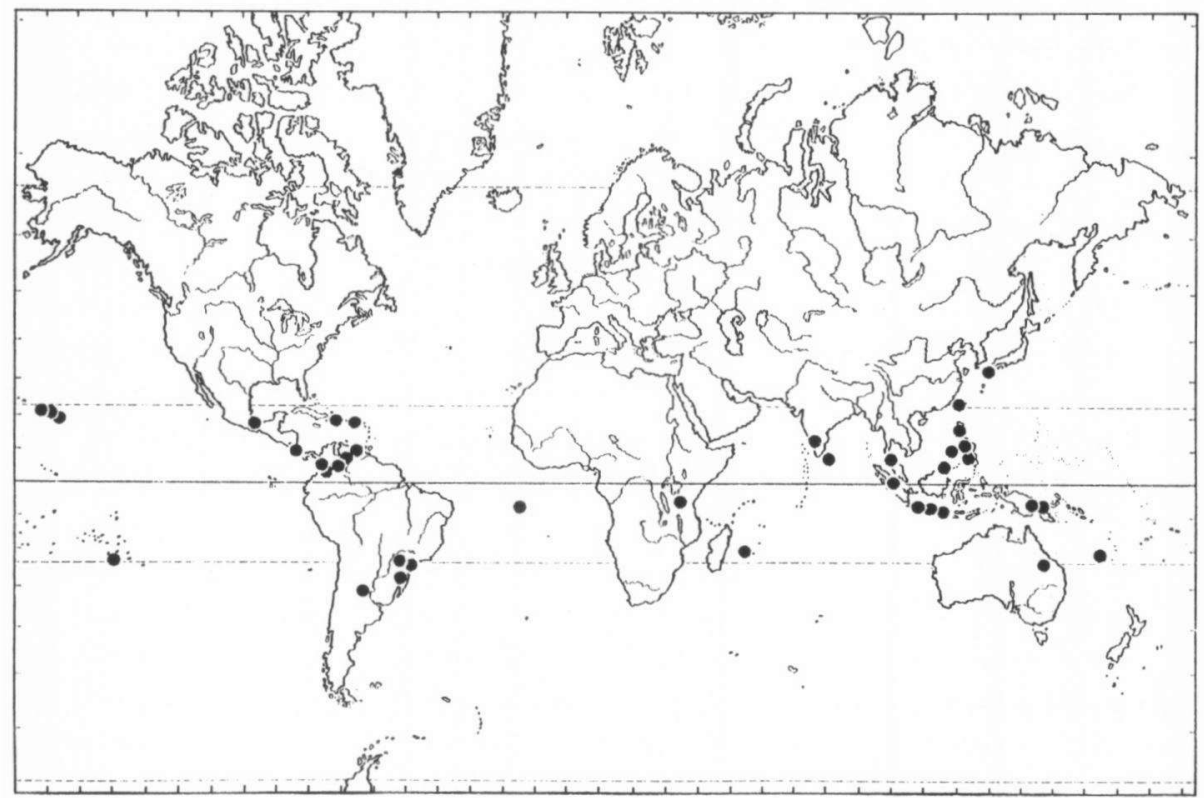

Figure 30. Megalospora sulphurata, distribution. 
"forêt dense", and as phorophytes Acacia koa, Corposma and Kukui tree; for India: "remains of mature rain forest"; for Java, Indonesia: "rain forest" and "thicket", and as phorophytes Altingia excelsa, Araucaria excelsc, Eurya glabra, Ficus cuspidata, F. rostrata and Turpinia pomifera; for Malaya: "oak forest"; for New Guinea: Nothofagus-forest, Nothofagus-Pandanus-forest, Araucama cunninghomii-forest, and as phorophytes Dalbergia and Podocarpus compactus; for the Philippines: "virgin dipterocarp forest", "mossy oak forest", "coconut grove" and "secundary forest"; and for Sabah: "mossy wood", "open wood" and "dry forest". Apparently the species is not very selective, and is able to maintain itself in secondary vegetation.

\section{Remarks}

Megalospora sulphurata var. sulphurata differs from the other Megalosporaspecies with sulphurata-type spores usually by the orange-brown epithecium and the over $60 \mu \mathrm{m}$ long spores with smooth epispore. Such long spores do occur also in $M$. campylospora, but in this species they are always with a warted epispore, and the thallus contains pannarin. A smooth epispore does occur also in M. subtuberculosa and sometimes in $M$. melanodermia, but these species differ by their under $45 \mu \mathrm{m}$ long spores.

The variability of Megalospora sulphurata var. sulphurata is very large. This has led to the description of many taxa which could not be maintained in this study. In fact some of these taxa had already been reduced to varieties or into synonymy by earlier authors, e.g. MUELLER ARG. (1894c), who unites Megalospora sulphurata with Lecidea taitensis, L. megacarpa and L. megaspora. VAINIO (1921b) introduced several new varieties to record this variation, viz. var. ZeconocheiZa, var. ochrocheila and var. phaeocheila. Var. Zeconocheila coincides rather well with the occurence of substance $B$ in the apothecium. Otherwise these varieties seem to be of little use in taxonomy because there are many intermediate specimens, and they do not coincide with other conspicuous variation, e.g. in the colour of the hypothecium or the spore size.

The variability concerns several conspicuous characters, some of which are discriminative for less variable species, e.g. 1. size of the apothecium; 2. size of the hymenium; 3 . size of the spores; 4. length/width ratio of the spore lumina; 5. pigmentation of the ectal and medullary excipulum and the subhypothecium; 6. presence of soredia or isidia; and 7. chemistry of the apothecium. All except the presence of soredia and isidia and the apothecium chemistry show a 
clinal variation. Some characters are variable even within a single thallus. No clear correlations could be found which might serve for delimitating infraspecific taxa.

To a certain degree the variability of Megalospora sulphurata is correlated with the geographical distribution. Specimens from the Philippines and New Guinea show nearly the whole range of variations. On the Hawaiian Islands, in Indonesia and on Sri Lanka dark apothecia predominate and in the former and the latter area large figures for hymenium size and spore size and elongate spore locules are frequent. The variation pattern of the neotropical plants appeared to be sufficiently different to base a separate variety on them, var. nigricans (p. 131).

A specimen with annotation "Japan", preserved in L and collected by $\mathrm{Ph}$. von Siebold, is apparently of doubtful origin. By its large, dark apothecia it fits more in the range of variation of the Indonesian populations than in the range of the populations of areas adjacent to Japan, e.g. Taiwan, where the apothecia are generally smaller and pale. Other Japanese specimens agree with the Taiwan population. The solution is given by TOUW (1971, p. 227), who states that some of von Siebold's specimens (i. c. mosses), said to originate from Japan, were actually collected in Indonesia.

As indicated already on p. 71 , isidiate plants have been found in four different areas, the Hawaiian Islands, Japan, New Guinea and Java. Their isidia show slight differences: in Japanese plants they are rather short and thick, stunted; in the Hawaiian population they are longer and rather irregularly thickened; on Java they are almost purely cylindrical, and thinner than in the preceding groups; and in New Guinean specimens they are cylindrical but rather strongly branched. Besides plants with well developed isidia, some with low, papilla-like isidia have been observed.

In Papua New Guinea isidiate plants appeared to be common near Wau, but they usually lack apothecia. Without apothecia such plants are actually unidentifiable, and will be inaccessible in herbarium collections. Thus their records will be more scarce than their presence in the field. In the same way sorediate specimens may be underrepresented in the available collections.

Sorediate plants are so far known from Ascension, the Hawaiian Islands (Kavai and Lanai), Jamaica, New Caledonia, the Philippines (Mindanao) and Tanzania. 
Megalospora sulphurata var. nigricans (Müll. Arg.) Riddle, Bull. Torrey Bot. Club 44: 529 (1917)

basionym: Patellaria vigilans var. nigxicans MUELLER ARG., Flora 64: 227 (1881)

type: Brasil, Apiahy, in truncis, Puiggary 472, martio 1879 (G) LECTOTYPE NOV. NOTE. The original description mentions many specimens. The lectotype was chosen from the first three specimens mentioned, because the further ones could not be traced with certainty: specimens in $G$ from the indicated collectors or with the indicated numbers do not bear the indication "var. nigricans", and in fact belong mostly to Catinaria versicolor. From the first three specimens, all from Brasil, the one with the largest number of apothecia has been chosen.

synonyms :

Megalospora vigilans var, nigricans (MUELLER ARG.) A. ZAHLBR., Catal, Lich. Univ. 4: 93 (1927).

Lecidea robusta FEE, Bull. Soc. Bot. France 20: 318 (1873)

original material: Brasil, Glaziou 1943 (BM, G, M, US) and 3478 (M, G).

NOTE. No lectotype for this taxon has been chosen because no specimens have been seen of PC, where the collections studied by FEE can be expected.

Lecidea fibrillosa FEE, Bull. Soc. Bot. France 20: 319 (1873)

type: Brasil, Glaziou 5004 (G, M ISOTYPES).

Description

This variety differs from Megalospora sulphurata var. sulphurata by the pre. sence of an olive-green or olive-brown to brown epithecium.

Distribution and ecology

Megalospora sulphurata var. nigricans is a neotropical taxon largely restricted to the mountains. Records are available from Mexico to Jamaica and southern Brasil and Argentina (Fig. 30). Remarkable is its apparent absence from the western parts of South America south of Colombia. The altitudinal records fall mostly between 2000 and $3000 \mathrm{~m}$, except in southern Brasil and Argentina, where the variety has been found even at sea level (Sipman 14127). The habitat indications include: "disturbed mossy forest", "original pine forest" and "bosque andino". Apparently the variety does occur in a wide range of open, humid forest types. All collections are from bark, except one (López \& Keogh 11439) from rock. 
Remarks

Megalospora sulphurata var. nigricans has been treated as a separate taxon in the present study to indicate the differences between the neotropical and the palaeotropical specimens of Megalospora sulphurata. These differences include, apart from the epithecium colour mentioned in the description, a1so: absence of substance B; usually lower hymenium; and usually smaller spores, which measure $(40-) 50-60(-80) \times(20-) c .25(-40) \mu$. Since none of these differences provides a constant differentiating character for all neotropical specimens, no subspecies has been introduced, but the most markedly different neotropical plants, those with an olive-green to olive-brown epithecium, have been treated as a distinct variety. Contrary to the taxa treated as subspecies in this study, var. nigricans can be often found in mixed populations with var. oulphurata.

In var. nigricans an additional strain occurs for the apothecium chemistry, without substances (Lб́pez 25672).

17a. Megalospora coccodes (Bél.) comb. nov. ssp. coccodes

basionym: Parmelia coccodes BELANGER in BELANGER \& BORY de SAINT VINCENT, Voyage aux Indes or., C. Botanique, pt. 2, Crypt., p. 125 (1846)

type: Mascarene Islands, La Réunion ("Ile de Bourbon"), sur l'écorce des arbres, Ch. Bélanger (PC-Montagne).

synonyms:

Biatora coccodes (BEL,) MONTAGNE, Ann. Sci. Nat., Bot., ser. 3, 10: 126 (1848);

- Bacidia cocoodes (BEL.) TREVISAN, Spighe e Paglie, p. 7 (1853); - Bombyliospora coccodes (BEL.) MASSALONGO, Atti I. R. Istit. Veneto, ser. 3, 5: 262 (1860); - Lecidea coccodes (BEL.) NYLANDER, Bull. Soc. Linn. Normandie, ser. 2, 2: $89(1868)$.

Leconora vigilans TAYLOR in HOOKER, London J. Bot. 6: 159 (1847) SYN. NOV; Patellaria vigizans (TAYL.) MUELLER ARG., Flora 64: 227 (1881) (Lich. Beitr. 286); - Lecidea vigilans (TAYL.) NYLANDER, Flora 69: 173 (1886); - Megalospora vigilans (TAYL.) A. ZAHLBR,, Catal. Lich, Univ. 4: 93 (1927); - Bombyliospora vigilans (TAYL.) DODGE, Beih. Nova Hedwigia 38: 76 (1971); - Lecidea versicolor var. viailans (TAYL.) NYLANDER, Acta Soc. Sci. Fenn. 7: 461 (1863); - Lecanora versicolor var. viailans (TAYL.) NYLANDER, Flora 52: 119 (1869); - Patellaria suiphurata var. vigilans (TAYL.) MUELLER ARG., Flora 69: 258 (1886) (Lich. Beitr. 1027).

type: Mascarene Islands, Mauritius (FH-Taylor, sheet 644).

NOTE. In the protologue two specimens are mentioned, one from Mauritius and one from Peru, which are separated in the print by a period. Examination of Taylor's herbarium in FH revealed that the Mauritius specimen belongs to Megalospora coccodes and the peruvian specimen to Catinaria versicolor. The Mauritius specimen, mentioned first, is in accord with all statements in the original des- 
cription, also some which do not fit the peruvian specimen, viz. "apotheciis ... disco rufescenti, pruinoso, .... margine incrassato ..... rufo-cinereo" and "a thin dark layer interposed between the lamina and white thallodal matter". The "minute granular buds" seem to agree with the tubercles, although these are not particularly well developed in the present specimen. The peruvian specimen disagrees with the cited points by having black apothecia with a thin, black margin and by lacking a brown subhypothecium. Moreover no structure is present which might represent the statement "minute granular buds". Thus both the description and the interpunction are in favor of the Mauritius specimen as the type. This is in accordance with the opinion of DODGE (1971) but opposed to NYLANDER (1859) who clearly had the peruvian specimen in mind when describing Lecanora vigitans as bisporous and considering it related to Catinaria versicolor. His interpretation has been followed in the nineteenth century literature, e.g. NYLANDER (1863, 1869, 1886) and MUELLER ARG. (1881), and thus the species became, like Catinaria versicolor, confused with Megalospora sulphurata, by e.g. MUELLER ARG. (1886).

Lecidea amplificans NYLANDER, Acta Soc. Scient. Fenn. 7: 462 (1863) SYN. NOV.; - Lecanora amplificans (NYL.) NYLANDER, Ann. Scienc. Nat., Bot. 5: 326 (1867); Lecania amplificans (NYL.) MUELIER ARG., Flora 65: 327 (1882) (Lich. Beitr. 426); - Bombyliospora complificans (NYL.) A. ZAHLBR., Catal. Lich. Univ. 7: 49 (1931).

type: Colombia, Villeta, alt. $1900 \mathrm{~m}$, ad corticem, Lindig 2812 (H-Nyl 18130, (UPS iso).

Lecidea conjuncta NYLANDER, Acta Soc. Scient. Fenn. 7: 462 (1862) SYN. NOV.; Patellaria conjuncta (NYL.) MUELLER ARG., Flora 65: 330 (J882) (Lich. Beitr. 435); - Bombyliospora conjuneta (NYL.) A. ZAHLBR., Catal. Lich. Univ. 7: 50 (1931).

type: Mascarene Islands, "hautes forêts de Mascareigne, sur l'écorce rugueuse des arbres", Bory de Saint Vincent (PC-Thuret).

Lecidea tuberculosa f. macrocarpa NYLANDER in HUE, Nouv. Arch. du Muséum, sér. 3, 3: 116 (1891) SYN. NOV.; - Bombyliospora tuberculosa f. macrocarpa (NYL. in HUE) A. ZAHLBR., Catal, Lich. Univ. 7: 57 (1931).

type: "in hb. Thuret", Mascarene Islands, La Réunion, Salazie, sur 1'écorce des arbres dans un forêt, Lepervanche-Mezières 85 , hb. Bory de St. Vincent (PCThuret).

NOTE. NYLANDER $(1859$, p. 260$)$ did not express originally the intention to create a new taxon by his statement "Variat macrocarpa ...", because he uses the abbreviation "var." and places the name in italics whenever he describes varieties. Thus his statement does not form a valid publication according to the code (STAFLEU c.8, 1978, art. 34, 1) and HUE (1891) validates the present taxon.

The type reference in the protologue, "in hb. Thuret", is scarce. In the herbarium Thuret (PC) a specimen has been found with the annotation "Lecidea tuberculosa FEE $\mathrm{f} . "$. This is considered here to be the type because of the indication that it concerns a deviating specimen, and because it agrees with NYLANDER's statement (1859) "thecis 2-4-sporis". Apparently the author confused MegaZospora coccodes with $M$. tuberculosa, for he uses (1. c.) for the specimens of the latter species the name Lecidea melanocarpa. 


\section{Description}

Thallus pale grey, rather thin, rather smooth, with c. $0.5 \mathrm{~mm}$ wide tubercles which often erode to leave soralia-like white spots. Soredia and isidia absent. Chemistry: pannarin and zeorin.

Apothecia c. $2 \mathrm{~mm}$ diam., c. $1.0 \mathrm{~mm}$ when young, and up to $3 \mathrm{~mm}$, c. $650-750 \mu \mathrm{m}$ thick. Disc flat, convex in the larger apothecia, brown to darkbrown, sometimes slightly pruinose, dull. Margin flat or slightly prominent, rather thick, pale yellowish, dull.

Epithecium diffusely orange-brown, sometimes with crystals, 10-14 $\mu \mathrm{m}$ thick. Hymenium 230-280 $\mu \mathrm{m}$ high, I + blue by staining of the asci. Excipulum pale brown to brown, darker in the ectal part, with a darkbrown subhypothecium, sometimes covered by an extended attachment layer containing algae, with dense masses of tiny yellowish crystals in the upper part of the ectal excipulum, $K$-. Apothecium base c. $500 \mu \mathrm{m}$ wide. Apothecium chemistry: unknown substances $A$ and/or $C$. Crystals of Calcium Oxalate present in the medullary excipulum.

Spores about four per ascus when mature, bacillar-pluriseptate, curved, with thin septa (coccodes-type, p. 45 Fig. 6 D), 6-8-celled, 70-105 x 22-35 $\mu \mathrm{m}$. Spore wall c. $2 \mu \mathrm{m}$ thick. Epispore very thin, often indistinct, c. $0.5 \mu \mathrm{m}$ thick, smooth.

Pycnidia not observed.

Distribution and ecology

The specimens originate mainly from La Réunion and Mauritius, with single collections from Tanzania and Colombia (Fig. 31). The altitude records, $1700 \mathrm{~m}$ for Tanzania and $1900 \mathrm{~m}$ for Colombia, indicate that the species probably prefers low mountain areas. All specimens are on rather smooth treebark.

\section{Remarks}

Megalospora coccodes differs from its nearest relative, M. pruinata, with which it shares coccodes-type spores and pannarin, by its smaller spores, usually under $90 \mu \mathrm{m}$ long, and the pale apothecium margin which contains small crystal aggregates (visible in lactophenol-cottonblue preparations).

M. coccodes ssp. nigricans differs from ssp. coccodes by the presence of another crystalline substance in the excipulum. Moreover it differs in distribution, occuring only in Southeast Asia.

The specimens from Tanzania and Colombia differ from those from the Mascarene Islands by their pruinose apothecia and crystals in the epithecium. The colombian 


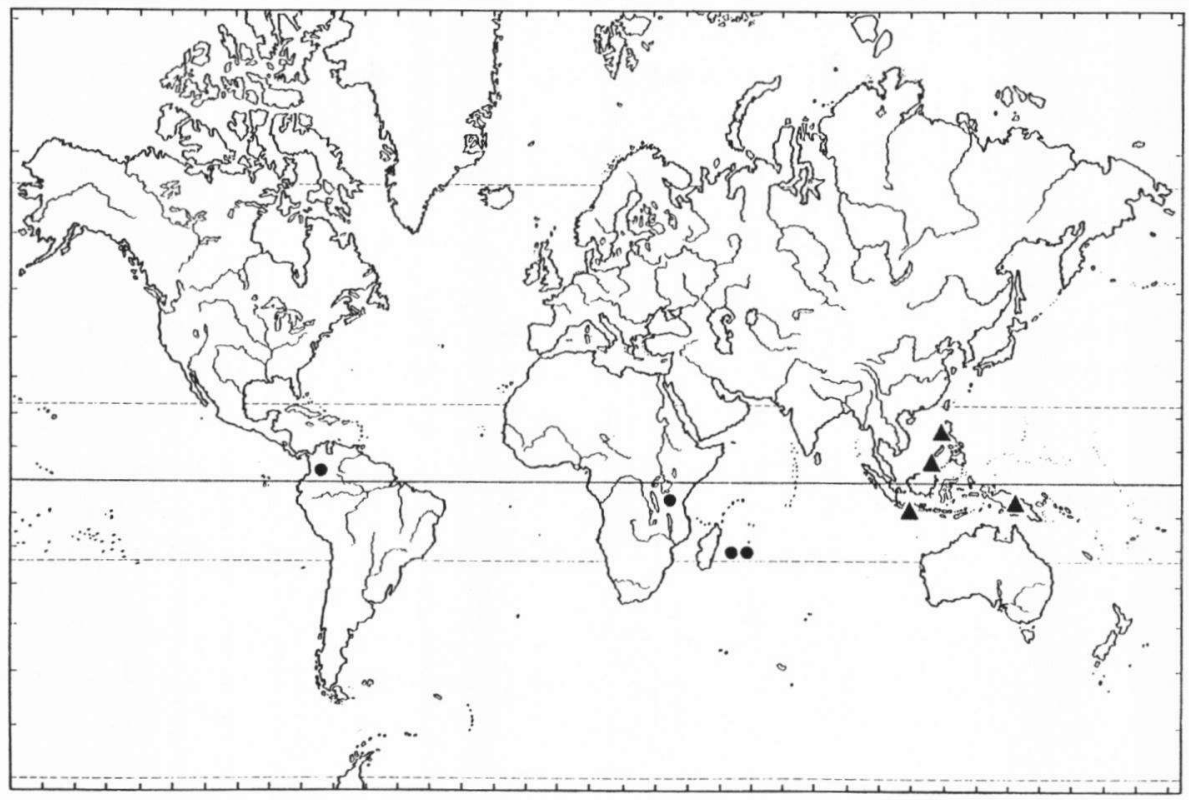

Figure 31. Megalospora coccodes, distribution. - = ssp. coccodes, A = ssp. nigmicans.

record forms a remarkable range extension. This is the more remarkable because no more specimens of the species have been found elsewhere in America, not even in the closely adjacent and much better investigated parts of Venezuela.

17b. Megalospora coccodes ssp. nigricans (Müll. Arg.) comb. nov.

basionym: Leconia complificans var, nigricans MUELLER ARG., Flora 65: 327

(1882) (Lich. Beitr. 426).

type: Indonesia, Java, Anon. $32 \mathrm{pr}$. p. (L, ISO in G).

\section{synonym:}

Bombyliospora amplificans var. nigricans (MUELL. ARG.) A. ZAHLBR., Catal. Lich. Univ. 7: 49 (1931)

NOTE. The specimen in $\mathrm{L}$ is considered to be the type, because MUELLER (1882) indicates that the original material is in $L$, and because the specimen in $G$, evidently a fragment from the same material, bears the indication "ut in typo". 


\section{Description}

Thallus pale grey to whitish, rather thin, rather smooth. Soredia and isidia absent. Chemistry: pannarin and zeorin.

Apothecia c. $2 \mathrm{~mm}$ diam., 1.1-1.2 $\mathrm{mm}$ when young, and up to $3.5 \mathrm{~mm}, c .500-700$ Im thick. Disc flat, becoming slightly convex in larger apothecia, pale brown to darkbrown, often whitis-pruinose, dull. Margin prominent, thick, pale yellowish, du11.

Epithecium diffusely orange-brown or olivaceous brown, usually with a granular top-layer which disappears in lactopheno1-cottonblue preparations, sometimes (Sipman 15708) with larger crystals resembling those in the ectal excipulum, 12-15 $\mu \mathrm{m}$ thick. Hymenium 200-260 $\mu \mathrm{m}$ high, I + blue in the basal part, sometimes also in the ascus tips. Excipulum pale brown, with a black-brown subhypothecium, more or less covered by an extended attachment layer containing algae, in the upper part of the ectal excipulum with elongate, white, c. $4 \times 1 \mu \mathrm{m}$ large crystals in variable quantities, which may penetrate in tongues rather far into the medullary excipulum and consist probably of Calcium Oxalate, $K$-. Apothecium base c. $500 \mu m$ wide. Apothecium chemistry: unknown substances A and C (C dominant). Crystals of Calcium Oxalate concentrated in the ectal excipulum, and penetrating marginally in the medullary excipulum.

Spores 2-6 per ascus when mature, bacillar-pluriseptate, slightly curved, with thin septa (coccodes-type, p. 45 Fig. 6 D), (6-)8(-10)-celled, 75-100 x 21-33 $\mu \mathrm{m}$. Spore wall c. $2 \mu \mathrm{m}$ thick: Epispore very thin, c. $0.5 \mu \mathrm{m}$, smooth.

Pycnidia not observed.

\section{Distribution and ecology}

Megalospora coccodes ssp. nigricans is known from the tropical mountains of Indonesia (Java), Papua New Guinea, the Philippines (Luzon) and Sabah (Fig. 31), at elevations ranging from 1350 to $3000 \mathrm{~m}$. The New Guinean collections are from bark of canopee branches in mossy forest.

\section{Remarks}

For the differences with related taxa, see the remark under the description of Megalospora coccodes ssp. coccodes.

There is a considerable variation in epithecium structure in the specimens from New Guinea. Two collections (Sipman 16023, 16024b) show a brown disc without any trace of pruina. Another collection (Sipman 15708) has a layer in the epithecium of the same crystals as in the ectal excipulum, apparently of 
Calcium 0xalate. More material from this area is required to determine the taxonomic significance of these differences.

18. Megalospora maderensis (Krempelh.) comb. nov.

basionym: Leconora amplificans var. maderensis KREMPELHUBER, Flora 60: 233 (1868).

type: Madeira, B. Castillo da Peira (a Barao de Castelo de Paiva, according to TAVARES 1958) $11(\mathrm{M}$, TYPE and ISO).

NOTE. In $M$ there are four specimens of the present species which are collected by "B. Castillo da Peira", two bearing nr. 11 and two with nr. 34. One of the specimens with nr. 11 bears on its label the same spore measurements as are given in the original description. Therefore it is considered to be the type. A second specimen, with nr. 34, bears the identification "Lecanora amplificans v. maderensis Krplh. ad int.", written in pencil, in the same handwriting as the type. Two further specimens, with nr. 11 and 34 , bear the identification "Lecanora amplificans v. maderensis" in a different handwriting. These are apparently duplicates. The illustration in TAVARES (1958, P1. 2, Fig. 2) represents the duplicate of $\mathrm{nr} .34$.

synonyms :

Dromoulinia maderensis (KREMPELH.) STEIN, 60 Jahresber. Schles. Ges. vaterl. Kultur, p. 231 (1883); - Lecidea maderensis (KREMPELH.) NYLANDER apud HUE, Nouv. Arch. du Muséum, sér. 3, 3: 116 (1891); - Bomby Ziospora maderensis (KREMPELH.) TAVARES, Bol. Soc. Brot., ser. 2, 32: 231 (1958).

\section{Description}

Thallus yellowish grey, thick, rugulose or irregularly warted, irregularly cracked. Soredia and isidia absent. Chemistry: usnic acid and zeorin.

Apothecia c. $2 \mathrm{~mm}$ diam., c. $1.0 \mathrm{~mm}$ when young, and up to $3 \mathrm{~mm}, 500-750 \mu \mathrm{m}$ thick. Disc flat, in larger apothecia convex, darkbrown to nearly black, epruinose, dull. Margin prominent, thick, pale yellowish, epruinose, dull.

Epithecium diffusely orange-brown to brown, 14-20 $\mu \mathrm{m}$ thick. Hymenium 160-240 $\mu \mathrm{m}$ high, $I+$ blue in its basal part and in the asci, mainly the tips. Excipulum yellowish with a brown subhypothecium, sometimes covered by an extended attachment layer containing algae, or containing algae in the parathecial crown, with dense masses of tiny yellowish crystals in the upper part of the excipulum, $\mathrm{K}+$ ye11ow. Apothecium base 440-640 $\mu \mathrm{m}$ wide. Apothecium chemistry: unknown substan- 
ces $A$ and $C$. Crystals of Calcium Oxalate present in the medullary excipulum.

Spores about four per ascus when mature, bacillar-pluriseptate and curved (coccodes-type, P. $45 \mathrm{Fig} .6 \mathrm{D})$, with thickened edges around the septa, 4(-6)-

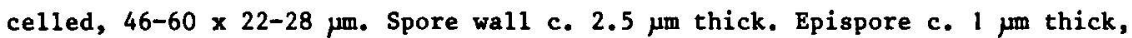
smooth.

Pycnidia not observed.

\section{Distribution and ecology}

All collections of Megalospora maderensis originate from Madeira (Fig. 32 ). They are on rather smooth, c. $2 \mathrm{~mm}$ thick bark, and as phorophyte of one specimen is mentioned Ocotea foetens ("Oreodaphne foetens"). TAVARES (1952) records ele-

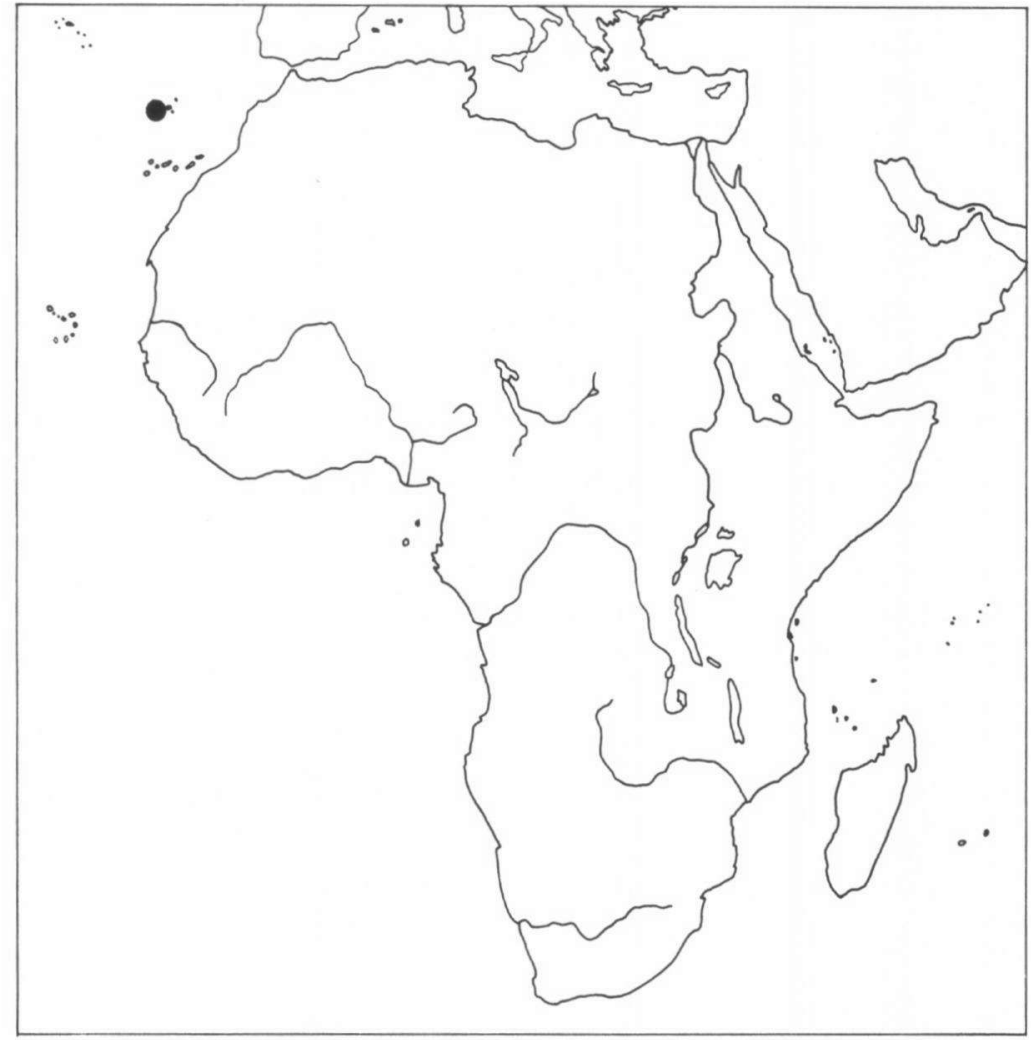

Figure 32. MegaLospora maderensis, distribution. 
vations from 850 to $1000 \mathrm{~m}$, and as substrate Laums canariensis-bark and rock.

\section{Remarks}

Megalospora maderensis is distinguished from all Megalospora species with bacillar spores by the presence of clearly thickened edges around the spore septa. This feature and the presence of usnic acid are clear differences with $M$. coccodes which is the most resembling species and shares the presence of coccodes-type spores and the occurence of yellowish crystal aggregates in the ectal excipulum.

The thickened edges of the spore septa in Megalospora maderensis resemble those in $M$. sulphurata and related species, but the thickenings are more gradual. Also in other respects $M$. maderensis resembles $M$. sulphurata more than other species with coccodes-type spores do, by the presence of usnic acid and a thick epispore. However, there are also conspicuous differences, e.g. the apothecium chemistry, with its $\mathrm{K}+$ yellow reaction without presence of substance $B$, and the presence of yellowish crystal aggregates in the ectal excipulum.

\section{Megalospora pachycheila (Tuck.) comb. nov.}

basionym: Lecidea pachycheila TUCKERMAN in NYLANDER, Ann. Sci. Nat., 4 ser., bot., 19: 352 (1863).

type: Cuba "In ins. Cuba", C. Wright, left piece (H-Nyl. 18123b) LECTOTYPE NOV. NOTE. The name of the present species has been published by NYLANDER in the year before TUCKERMAN's own description (1864) became available. The first locality mentioned by NYLANDER is Cuba, therefore the lectotype has been selected among the Cuban specimens in Nylander's herbarium. The left piece is chosen because it bears more apothecia.

synonyms:

Patellaria pachycheila (TUCK.) MUELLER ARG., Flora 65: 488 (1882) (Lich. Beitr. 511); - Heterothecium pachycheilum (TUCK.) TUCKERMAN, Synops. North Amer. Lich. 2: 56 (1888); - Bombytiospora pachycheila (TUCK.) A. ZAHLBR., Sitzungsber. Kais. Akad. Wiss. Wien, math,-naturw. Classe 3(1): 397 (1902); - Heterothecium tuberculosum var. pachucheilum (TUCK.) TUCKERMAN, Gener. Lich., p. 175 (1872).

\section{Description}

Thallus pale grey, rather thin, rather smooth but more or less covered with c. $0.5 \mathrm{~mm}$ wide tubercles, which may erode and leave white, soralia-like spots, occasiona1ly (in South Brasil) with nearly isidium-1ike, c. $0.1 \mathrm{~mm}$ wide and 
$0.2 \mathrm{~mm}$ long pustules. True soredia and isidia absent. Chemistry: lichexanthone and zeorin.

Apothecia c. $1.5 \mathrm{~mm}$ diam., 0.7-0.8 $\mathrm{mm}$ when young, and up to $2.5 \mathrm{~mm}$, c. 350$420 \mathrm{\mu m}$ thick. Disc flat, convex in larger apothecia, brown to darkbrown, sometimes slightly pruinose, dull. Margin little prominent, rather thick, pale yellowish, epruinose, dull.

Epithecium diffusely orange-brown (to brown), 10-14 $\mu$ m thick. Hymenium (105-) 130-160(-180) $\mu \mathrm{m}$ high, I + blue caused by staining of the asci. Excipulum pale brown to yellowish brown, often with a darkbrown subhypothecium, sometimes covered by an extended attachment layer containing algae, with tiny yellowish crystals in dense masses in the upper part of the ectal excipulum, $K$-. Apothecium base 350-460 $\mu \mathrm{m}$ wide. Apothecium chemistry: unknown substances A and C (C usually dominant). Crystals of Calcium Oxalate sometimes present in the medullary excipulum.

Spores about four per ascus when mature, bacillar-pluriseptate, curved (coccodes-type, p. 45 Fig. 6 D), 4-6-celled, 70-85 × 20-30 $\mu \mathrm{m}$. Spore wall c. $2 \mu \mathrm{m}$ thick. Epispore very thin, often indistinct, a. $0.5 \mu \mathrm{m}$ thick, smooth.

Pycnidia not observed.

\section{Distribution and ecology}

Megalospora pachycheila has a disjunct distribution in the neotropics, with a northern range comprising the southern United States, Mexico and Cuba, and a a southern range in southern Brasil (Fig. 33). No collections were available from intermediate areas, like Venezuela, where many Megalospora specimens have been collected.

Probably the species inhabits forest in low mountain areas. For Cuba and Mexico altitudes are given of 750 and $1000 \mathrm{~m}$. In the northernmost and southernmost parts of its range it apparently descends to sea level, as a find in a mangrove on the Ilha de Cananeia, Edo. Sao Paulo, Brasil, shows. All specimens are from rather smooth-barked trees.

\section{Remark}

The present species resembles most closely Megalospora coccodes, and especially its ssp. coccodes, by the pale apothecium margin which contains yellowish crystal aggregates in the ectal excipulum, and by the coccodes-type spores. Differences are the lower hymenium, and especially the presence of lichexanthone in the thallus. This substance has not been found in any other species of Megalo- 


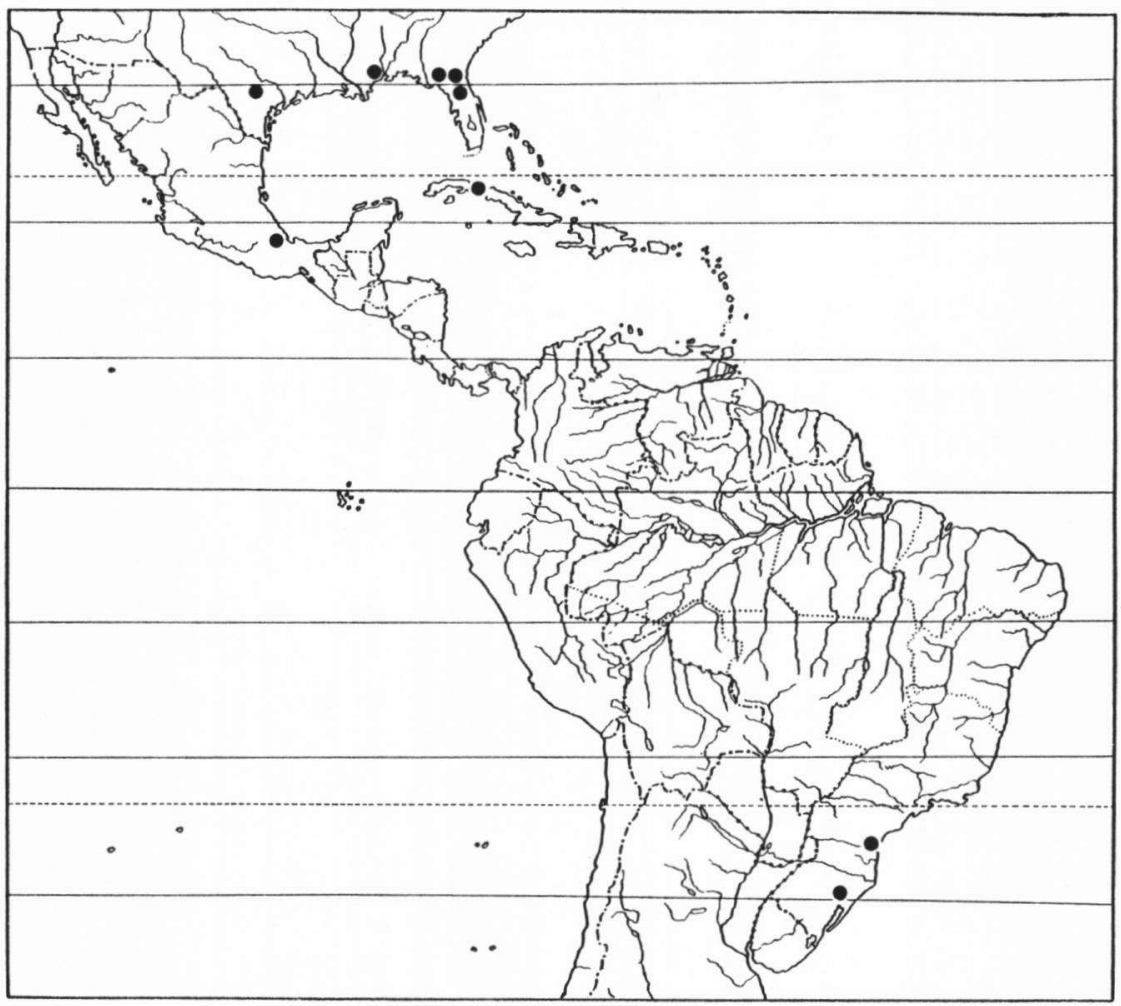

Figure 33. Megalospora pachycheila, distribution.

spora.

20a. Megalospora pruinata (Müll. Arg.) comb. nov. ssp. fusca ssp. nov. type: Papua New Guinea, prov. Chimbu, Pindaunde valley near Mount Wilhe1m, in mossy dwarfforest on NE-facing slope along lake Piunde, a1t. $3550 \mathrm{~m}$, H. Sipman 15834, 14.VIII. 1981 (U, ISO in UPNG).

Diagnosis: Thallus albicans, laeviusculus, sorediis isidiisque destitutus, pannarinum et zeorinum continens. Apothecia c. $2 \mathrm{~mm}$ lata et c. $700 \mu \mathrm{m}$ crassa. Discus planus, fuscus vel niger, nonnumquam leviter pruinosus, opacus. Margo prominens, plerumque crassus, fuscus vel niger, pruinosus opacusque vel epruinosus 
nitidiusculusque. Epithecium diffusiter olivaceo-fuscum vel rufum, nonnumquam obscuro-olivaceum, plerumque strato granulare provisum, 8-15 $\mu \mathrm{m}$ crassum. Hymenium 230-280 $\mathrm{mm}$ crassum, I + coerulescens in parte basali. Excipulum pallidum vel pallido-rufum, strato externo et subhypothecio fusco provisum, K-negativum. Basis apothecii 230-600 $\mu \mathrm{m}$ latus. Substantiae ignotae A et $\mathrm{C}$ presentes, crystal1a calcii-oxalatica in excipulo medullare provisa. Sporae binae, ternae vel quadernae, bacillares, leviter curvatae (typo "coccodes"), e (8-)10-12 cellulis compositae, magnitudine c. 90-110(-125) x 25-28 $\mu \mathrm{m}$, septis tenuibus et pariete $2 \mu \mathrm{m}$ crasso, episporio c. $0.5 \mu \mathrm{m}$ crasso laeve. Sylvarum subalpinarum in montibus Novae Guineae incola.

\section{Description}

Thallus pale grey to white, rather thin, nearly smooth but following the irregularities of the substrate. Soredia and isidia absent. Chemistry: pannarin and zeorin.

Apothecia c. $2.0 \mathrm{~mm}$ diam., c. 0.8-1.2 mm when young, and up to $3.0 \mathrm{~mm}$, c. 700 (570-820) $\mu \mathrm{m}$ thick. Disc flat, only in some of the largest apothecia slightly convex, brown to black, often with a faint bluish pruina, dull. Margin prominent, usually very thick, darkbrown to black, usually concolorous with the disc, with the same faint bluish pruina and then dull, or without and then slightly glossy.

Epithecium diffusely olive-brown to brown or orange-brown, sometimes dark olive-green, usually with a granular top-layer which disappears in lactopheno1cottonblue preparations, 8-15 $\mu \mathrm{m}$ thick. Hymenium 230-280 $\mu \mathrm{m}$ high, I + blue in its basal part and usually only slightly so in the ascus tips. Excipulum yellowish to pale brown with a thin darker ectal layer and a black-brown subhypothecium, $\mathrm{K}$-. Apothecium base 230-600 $\mu \mathrm{m}$ wide. Apothecium chemistry: unknown substances $A$ and $C$, usually $A$ dominant. Crystals of Calcium Oxalate regularly present in the medullary excipulum.

Spores $2(-4)$ per ascus, bacillar-pluriseptate, curved, with thin septa (coccodes-type, p. 45 Fig. 6 D), (8-) 10-12-celled, 90-110(-125) x 25-28 $\mu \mathrm{m}$. Spore wall c. $2 \mu \mathrm{m}$ thick. Epispore very thin, c. $0.5 \mu \mathrm{m}$ thick, smooth.

Pycnidia not observed.

\section{Distribution and ecology}

Megalospora pruinata ssp. fusca is a mountain species found only on New Guinea (Fig. 34), at elevations ranging from 2100 to $3600 \mathrm{~m}$. In stunted forests near the treeline it grows on trunks and low branches, often over hepatics, in sheltered but not too dark places. In tall forests at lower elevations it occurs on canopee branches. 


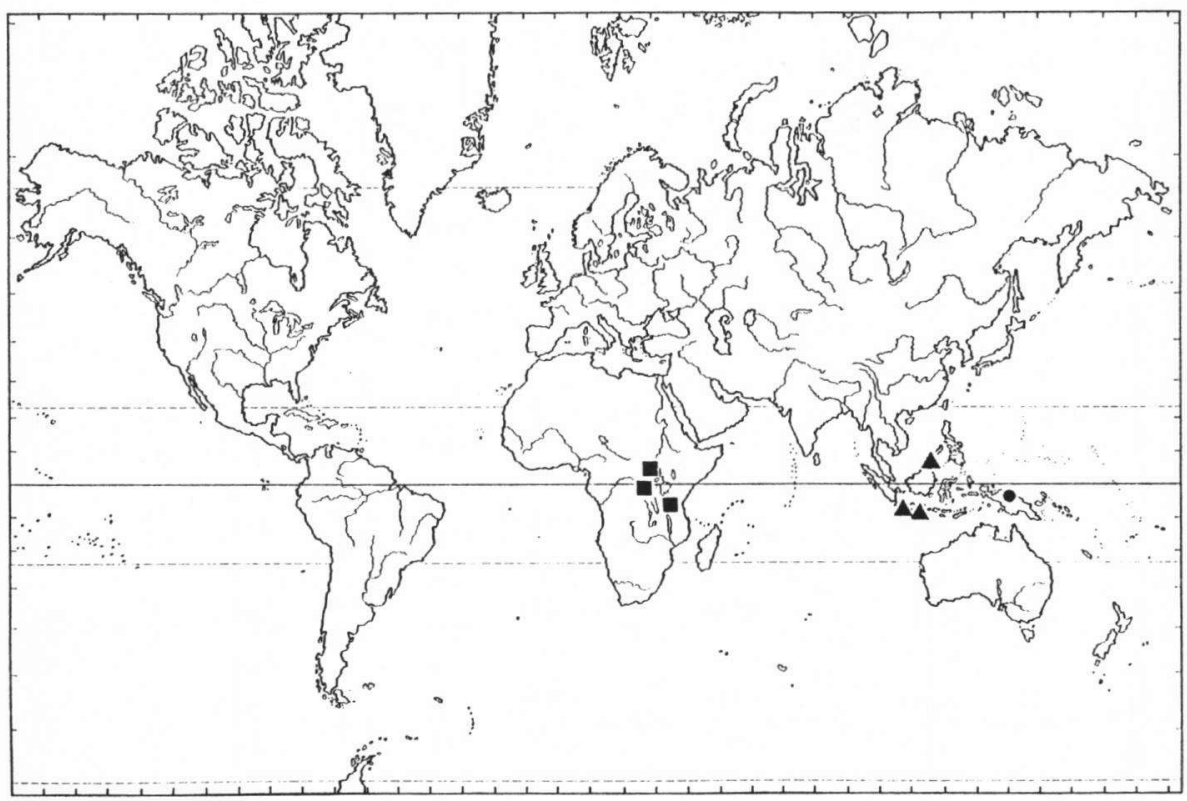

Figure 34. Megatospora pruinata, distribution. $\bullet=\operatorname{ssp}$. fusca; $\mathbf{\Delta}=\mathbf{s s p}$. lamii; = ssp. pruinata.

\section{Remarks}

For the differences with its closest relatives, see under Megalospora pruinata ssp. pruinata, p. 146.

The collection from Wau (Sipman 15648i) shows slight deviations from the description above: its apothecia have very pale brown discs with contrasting brown-black margins, and its thallus shows some c. 0.4 mide tubercles.

20b. Megalospora pruinata ssp. Iamii (Groenh.) stat. nov. basionym: Bomby Ziospora Zamii GROENHART, Blumea suppl. 4: 110 (1958). type: Indonesia, West Java, Tjibodas, Mt. Gedeh, in rain forest, on Turpinia pomifera, $4 \mathrm{~m} \mathrm{high,} \mathrm{exposed,} \mathrm{alt.} 1400 \mathrm{~m}$, Nurta \& Madrodji in coll. van Ooststroom 14340, 14.IV.1950 (L) 


\section{Description}

Thallus pale grey, rather thin, nearly smooth but following the irregularities of the substrate. Soredia and isidia absent. Chemistry: pannarin and zeorin.

Apothecia c. $2 \mathrm{~m}$ diam., c. $1.2 \mathrm{~mm}$ when young, and up to $2.5 \mathrm{~mm}$, c. 550-750 $\mu \mathrm{m}$ thick. Disc flat, black but often covered by a thin bluish-white pruina, dul1. Margin prominent, very thick, black and frequently white-pruinose, dull.

Epithecium diffusely olive-green to blackish, with a granular top-layer which disappears in lactophenol-cottonblue preparations, 7-15 $\mu \mathrm{m}$ thick. Hymenium 210$280 \mu \mathrm{m}$ high, I + blue. Excipulum olivaceous yellow to brown, with a thin darker ectal layer and a black-brown subhypothecium, often covered by an extended attachment layer containing algae, R -. Apothecium base c. $220 \mu \mathrm{m}$ wide. Apothecium chemistry: unknown substance A, sometimes also C. Crystals of Calcium Oxalate present in the medullary excipulum.

Spores $2(-6)$ per ascus, bacillar-pluriseptate, slightly curved, with thin septa (coccodes-type, p. 45 Fig. 6 D), (6-)8-12-celled, 90-120 x 25-35 $\mu \mathrm{m}$. Spore wall c. $2 \mu \mathrm{m}$ thick. Epispore indistinct, c. $0.5 \mu \mathrm{m}$ thick, smooth.

Pycnidia not observed.

\section{Distribution and ecology}

Megalospora prinata ssp. Zamii was at hand from Java and Bornea (Fig. 34), but is recorded by GROENHART (1958) also from Malaya. It occurs at elevations of 1400-2200 m, and as phorophytes are mentioned Altingia excelsa and Turpinia pomifera.

\section{Remarks}

For the differences between Megalospora pminata ssp. Zamii and its related taxa, see under ssp. pruinata, p. 146.

The observations on ssp. Zamii differ somewhat from the detailed description by GROENHART (1958). The blue colour of the apothecia is not present any more in the same collections which he described, and his measurements of hymenium height and spore size are somewhat larger, viz. 260-350 $\mu \mathrm{m}$ and 26-25 x 100-140 $\mu \mathrm{m}$. 
20c. Megalospora pruinato (Müll. Arg.) comb. nov. ssp. pruinata

basionym: Patellaria pruinata MUELLER ARG., Engler Bot. Jahrb. 20: 273 (1894).

type: Tanzania, Usambara, Holst 1411 (G) LECTOTYPE NOV.

NOTE. MUELLER ARG. (1894b, p. 273) mentions two collection when describing

the present species, Holst nr, 1404 and 1411, both mounted on the same card in G. Out of these $\mathrm{nr} .1411$ has been chosen as the lectotype because it has more apothecia.

synonym:

Bomby Ziospora pruinata (MUELL. ARG.) A. ZAHLBR., Catal. Lich, Univ. 7: 53 (1931).

Description

Thallus grey, rather thin, more or less granular with c. $0.1 \mathrm{~mm}$ diam. granules and sometimes with c. 0.5-0.8 mm wide tubercles which erode easily to leave white soralia-like spots. Soredia and isidia absent. Chemistry: pannarin and zeorin

Apothecia c. $1.5 \mathrm{~mm}$ diam., c. 0.7-0.9 mm when young, and up to $2.5(-5) \mathrm{mm}$, c. $470 \mu$ thick. Disc flat or in large apothecia convex, pale brown to darkbrown, often with a faint whitish pruina, dull. Margin more or less prominent, rather thin, darkbrown or somewhat pale, paler or darker then the disc, often with the same faint pruina, dull.

Epithecium diffusely orange-brown, sometimes with a granular top-layer which disappears in lactophenol-cottonblue preparations, c. $15 \mu \mathrm{m}$ thick. Hymenium 180$190 \mu \mathrm{m}$ high, with $\mathrm{I}+$ blue asci but otherwise unstained by I-solution. Excipulum yellowish to pale brown, slightly darker in the ectal part and with a darkbrown subhypothecium, K -. Apothecium base c. $230 \mu \mathrm{m}$ wide. Apothecium chemistry: unknown substances $A$ and $C$ (C dominant). Crystals of Calcium Oxalate absent.

Spores 2-3 per ascus when mature, bacillar-pluriseptate and curved (coccodestype, p. 45 Fig. 6 D), (8-) 10-celled, 110-115 × 30-35 $\mu \mathrm{m}$. Spore wall c. $2 \mu \mathrm{m}$ thick. Epispore very thin, c. $0.5 \mu \mathrm{m}$, smooth.

Pycnidia not studied.

Distribution and ecology

This subspecies is only known from the mountains of tropical East and Central Africa (Fig. 34), from elevations around $2000 \mathrm{~m}$. As phorophytes are indicated Nuxia congesta and Lepidotrichilia volkensii. 


\section{Remarks}

Megalospora pruinata belongs to the group of species with coccodes-type spores. Within this group it differs from $M$. thomensis by the absence of usnic acid and the larger spores, from $M$. coccodes by the larger spores, which are generally over $90 \mu \mathrm{m}$ long, and the dark apothecium margin, from $M$. maderensis by the absence of usnic acid and of thick edges around the spore septa, and from $M$. pachycheila by the absence of lichexanthone and the larger spores.

The material of $M$. pruinata falls apart in three allopatric groups. The african specimens, ssp. pruinata, are marked by their low hymenium; other differences, such as the sialler apothecia, the general presence of an orange-brown epithecium, the dominance of substance $C$, are only gradual. The specimens from Java and Sabah have deep black apothecia, often with a whitish pruina: ssp. Zamii. The specimens from New Guinea, united in ssp. fusca, have darkbrown, only faintly pruinose apothecia. The difference between the latter two subspecies is rather small and difficult to observe in poorly preserved specimens. Anatomically the difference is more clear by the epithecium colour, which is olive-brown to orange-brown in ssp. fusca and usually greenish black in ssp. Zamii.

\section{Megalospora thomensis (Nyl.) comb. nov.}

basionym: Lecidea thomensis NYLANDER, Flora 69: 173 (1886).

type: Sao Thomé, "In Pico de S. Thomé", Moller 937, 1885 (H-Ny1. 18124)

synonyms :

Bomby Ziospora thomensis (NYL.) A. ZAHLBR,, Catal. Lich. Univ, 7: 56 (1931).

PatelZaria togoensis MUELLER ARG., Engler Bot. Jahrb. 15: 506 (1893) SYN. NOV.; - Lecidea togoensis (MJELL. ARG.) STIZENBERGER, Ber. Thätigk. St. Gallischen Naturwis. Ges. 1893-94, p. 248 (1895); - Bombyliospora togoensis (MUELL. Arg.) A. ZAHLBR,, Cata1. Lich. Univ. 7: 56 (1931). type: Togo, Bismarksburg, Büttner (G).

\section{Description}

Thallus pale greenish grey, rather thin, smooth or with a slightly granular surface (granules $0.1-0.2 \mathrm{~mm}$ wide). Soredia and isidia absent. Chemistry: usnic acid and zeorin.

Apothecia c. $1 \mathrm{~mm}$ diam., c. 0.5-0.7 mm when young, and up to $2 \mathrm{~mm}, \mathrm{c} .350 \mu \mathrm{m}$ thick. Disc flat, in larger apothecia slightly convex, brown to darkbrown, slightly glossy. Margin prominent, rather thin, black, slightly glossy.

Epithecium diffusely orange-brown or olivaceous-brown, $15 \mu \mathrm{m}$ thick. Hymenium 


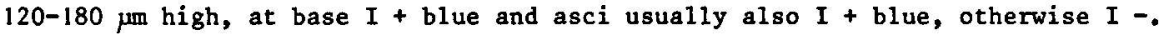
Excipulum yellowish to brown, when pale with a thin orange-brown layer in the subhypothecium, R -. Apothecium base c. $250 \mu \mathrm{m}$ wide. Apothecium chemistry: unknown substances $A$ and $C$. Crystals of Calcium Oxalate sometimes present in the medullary excipulum.

Spores 2-4 per ascus when mature, bacillar-pluriseptate and curved (coccodestype, p. 45 Fig. 6 D), the shorter ones straight, 2-4(-7)-septate, 30-45 x 14-22 $\mu \mathrm{m}$ to $45-80 \times 22-32 \mu \mathrm{m}$. Spore wall c. $2 \mu \mathrm{m}$ thick. Epispore very thin, c. $0.5 \mu \mathrm{m}$ thick, smooth.

Pycnidia not observed.

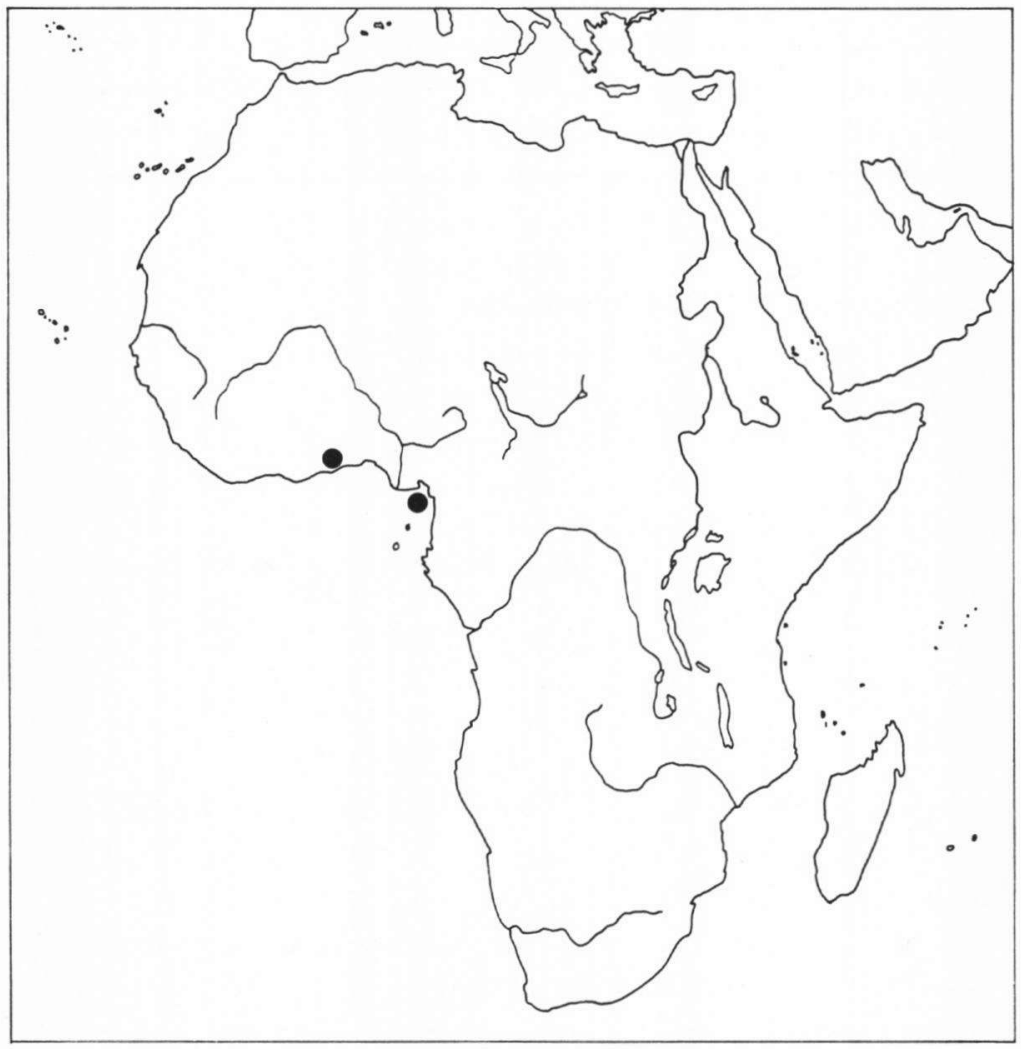

Figure 35. Megalospora thomensis, distribution. 
Distribution and ecology

Megalospora thomensis is known only from old collections from two localities in tropical West Africa (Fig. 35), without altitude records, on bark.

\section{Remarks}

Among the Megalospora-species with coccodes-type spores, except $M_{\text {. maderen- }}$ sis, $M$. thomensis is characterised by the occurence of usnic acid. Moreover it differs from $M$. coccodes and $M$. pachycheila by the absence of crystalline substances in the upper part of the ectal excipulum, and frow $M$. pruinata by the

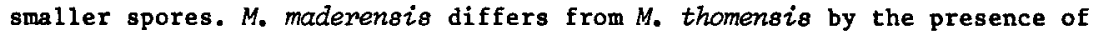
thickened edges around the spore septa, the presence of a yellowish granular substance in the ectal excipulum, and the larger apothecia with a yellow margin.

The spores of $M$, thomensis are unusually variable, being straight and 2-4celled in the specimens from Sao Thome, and curved and 4-6-celled in the specimen from Togo. Both groups have been united in a single species because there is an overlap in the spore-size and -septation, and because the curving of the spores can be considered as depending on their length.

Another remarkable feature in the spores is the occurence of bicellular ones. These have caused confusion with $M$. sulphurata (sub nom. Lecidea vigilans) by NYLANDER (1886) (only record of this species for West Africa, which is thus incorrect). However, plants with such spores are easily recognisable, because the bicellular spores are accompanied by numerous pluricellular ones and lack the thickened edges around the septa, characteristic for sulphurata-type spores. Such bicellular spores have only been found in specimens from Sao Thomé.

Remarkable is the strong similarity between $M$. thomensis and $M$. tuberculosa with tuberculosa-type spores. In fact no more differences than the spore type could be found.

\section{Megalospora albescens spec. nov.}

type: Papua New Guinea, prov. Chimbu, Pindaunde valley near Mt. Wilhelm, in mossy dwarfforest on NE-facing slope along lake Piunde, alt. $3520 \mathrm{~m}$, Sipman $15850,14$. VIII.1981 (U, ISO in UPNG)

Diagnosis: Thallus albicans, tenuis, rugulosus vel subgranulatus (granulis c. $0.1 \mathrm{~mm}$ latis), sorediis isidiisque destitutus, pannarinum zeorinumque continens. Apothecia c. 1.5 mm lata et 760-920 $\mu \mathrm{m}$ crassa. Discus persistenter planus, pallido-rufus vel fuscus, albo-pruinosus, opacus. Margo prominens, 
crassiusculus, pallido-rufus, albo-pruinosus, opacus. Epithecium diffusiter rufum vel fuscum, strato granulare obtectum, 12-14 $\mu \mathrm{m}$ crassum. Hymenium 220-230 m crassum, I + coerulescens in parte basali. Excipulum pallido-rufum, subhypothecio fusco provisum, K-negativum. Basis apothecii 450-800 $\mu$ m 1atum. Substantiae ignotae $\mathrm{A}$ et $\mathrm{C}$ presentes et nonnumquam crystalla calcii-oxalatica in excipulo medullare provisa. Sporae singulae, bacillares-pluriseptatae, rectae (typo "tuberculosa"), e 8-12 cellulis compositae, magnitudine c. 150-180 x 35-40 $\mu \mathrm{m}$, septis tenuibus et pariete c. $2 \mu \mathrm{m}$ crasso, episporio c. $0.5 \mu \mathrm{m}$ crasso laeve. Sylvarum subalpinarum Novae Guineae incola.

\section{Description}

Thallus pale grey, rather thin, rugulose to nearly granular, with c. $0.1 \mathrm{~mm}$ wide granules. Soredia and isidia absent. Chemistry: pannarin and zeorin.

Apothecia c. $1.5 \mathrm{~mm}$ diam., 0.8-1.1 mm when young, and up to $3.6 \mathrm{~mm}$, c. $760-$ $920 \mu \mathrm{m}$ thick. Disc flat, even in the largest apothecia, pale brown to darkbrown, with white pruina, dull. Margin prominent, rather thick, pale brown, with white pruina, dull.

Epithecium diffusely orange-brown to brown, with a granular top-layer which disappears in lactophenol-cottonblue preparations, 12-14 $\mu \mathrm{m}$ thick. Hymenium 220-230 $\mu \mathrm{m}$ high, at base I + blue, otherwise I + reddish. Excipulum yellowish to pale brown, with a black-brown subhypothecium, K -. Apothecium base 450-800 $\mu \mathrm{m}$ wide. Apothecium chemistry: unknuwn substances $\mathrm{A}$ and $\mathrm{C}$ (A dominant), sometimes present only in small amounts (or absent?). Crystals of Calcium 0xalate in the medullary excipulum sometimes present.

Spores solitary, bacillar-pluricellular with thin septa and straight (tuberculosa-type, p. 45 Fig. 6 C), 8-12-celled, c. 150-180 × 35-40 $\mu$ m. Spore wall c. $2 \mu \mathrm{m}$ thick. Epispore very thin, c. $0.5 \mu \mathrm{m}$ thick, smooth.

Pycnidia not observed.

\section{Distribution and ecology}

Megalospora albescens is known only from Mount Wilhelm, Papua New Guinea (Fig. 36), being collected on moss on low branches in subalpine dwarfforest at c. $3600 \mathrm{~m}$. altitude.

Remark

Megalospora albescens is distinctive by its white-pruinose apothecia, its high hymenium and its large spores. By its apothecium colour it resembles certain specimens of $M$. coccodes ssp. nigricans but that species differs by its coccodes-type spores and the presence of crystals in the ectal excipulum. 


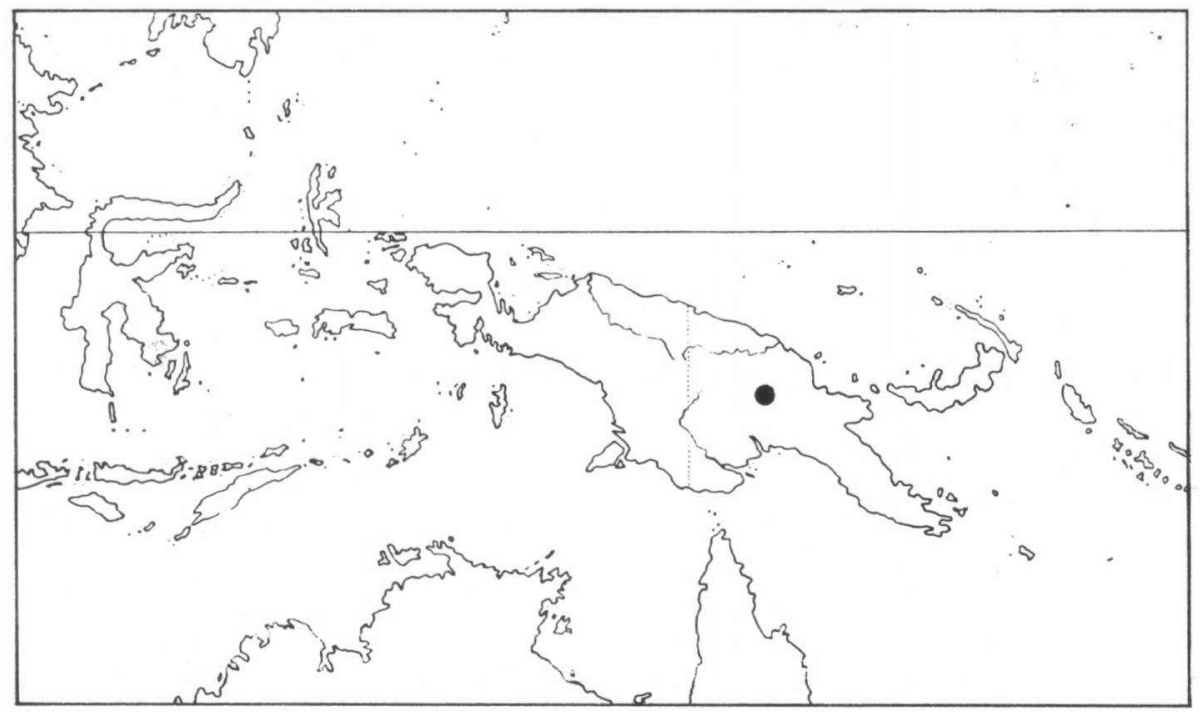

Figure 36. Megalospora albescens, distribution.

23. Megalospora australiensis (Müll. Arg.) comb. nov.

basionym: Patellamia australiensis MUELLER ARG., Flora 65: 488 (1882) (Lich. Beitr. 510).

type: Australia, Queensland, Toowoomba, Hartmann (G) LECTOTYPE NOV.

NOTE: In the herbarium of MUELLER ARG. two specimens are present which accord with the original description. Comparison of the spore measurements indicated on the specimens with those in the description made clear that both specimens have been used for the original description. Therefore as a lectotype is chosen the specimen with the highest number of well developed apothecia.

synonyms:

Bombyliospora australiensis (MUELL. ARG.) A. ZAHLBR., Catal. Lich. Univ. 7: 50 (1931).

Pateliaria ventricosa MUELLER ARG., Flora 65: 488 (1882) (Lich. Beitr. 511) SYN. NOV; - Bombuliospora ventricosa (MUELL. ARG.) A. ZAHLBR, Catal. Lich. Univ. 7: 57 (1931). type: Australia, Queensland, Toowoomba, Hartmann (G). NOTE. The only specimen and thus type of the present species agrees in all im- 


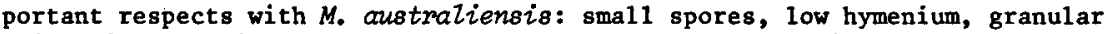
epithecium, chemistry, and notably the presence of algae in the medullary excipulum. MUELLER's statement $(1882 \mathrm{~b}, \mathrm{p} .488)$ that the spores occur with two in each ascus, is incorrect.

\section{Description}

Thallus grey, rather thick, rugulose and more or less cracked-areolate. Soredia and isidia absent. Chemistry: pannarin and zeorin.

Apothecia c. $1 \mathrm{~mm}$ diam., c. 0.4-0.5 mm when young, and up to $1.8 \mathrm{~mm}, \mathrm{c} .300-$ $450 \mu \mathrm{m}$ thick. Disc flat or, in the largest apothecia, convex, pink to brown, mostly with white pruina, dull. Margin more or less prominent, rather thin, pale yellowish and without pruina, or in a rim around the disc more pigmented or pruinose, glossy or dull.

Epithecium diffusely orange-brown or olivaceous brown, $15 \mathrm{~mm}$ thick, sometimes with a granular top-layer which disappears in lactophenol-cottonblue preparations. Hymenium 120-140 $\mathrm{mm}$ high, I + intensely blue. Excipulum pale with enclosed algal cells in a layer below the subhypothecium, sometimes covered by an extended attachment layer containing algae, with unclear yellowish crystal aggregates in the ectal excipulum, K - Apothecium base 240-350 $\mu \mathrm{m}$ wide. Apothecium chemistry: no detectable amounts of any substances, or perhaps traces of unknown substances $A$ and $C$. Crystals of Calcium Oxalate usually present in the medullary excipulum.

Spores solitary, bacillar-pluricellular with thin septa, straight (tuberculo-

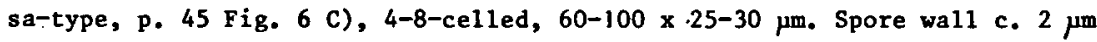
thick. Epispore very thin, c. $0.5 \mu \mathrm{m}$ thick, smooth.

Pycnidia not studied.

Distribution and ecology

Megalospora australiensis is only known from northern New South Wales and southern Queensland, Australia (Fig. 37). The specimens are on bark, and probably originate from humid mountain forest.

\section{Remarks}

A conspicuous feature of Megalospora autraliensis is the presence of algae in the medullary excipulum. Concentrations of them are present near the parathecium, and apparently the way for their distribution in the excipulum is the same as in Leconia sulphureofusca (cf. p. 43). In some apothecia algae are also present in the parathecial crown. These must have reached their position from the outside, probably from the extended attachment layer. Because an extended 
attachment layer is only occasionally present, this seems not to be the usual way for algae to reach the interior of the excipulum.

Besides by the algae in the apothecim, $M$. australiensis is also distinct from the most closely resembling species, such as $M$. tuberculosa, by the presence of crystal aggregates in the ectal excipulum.

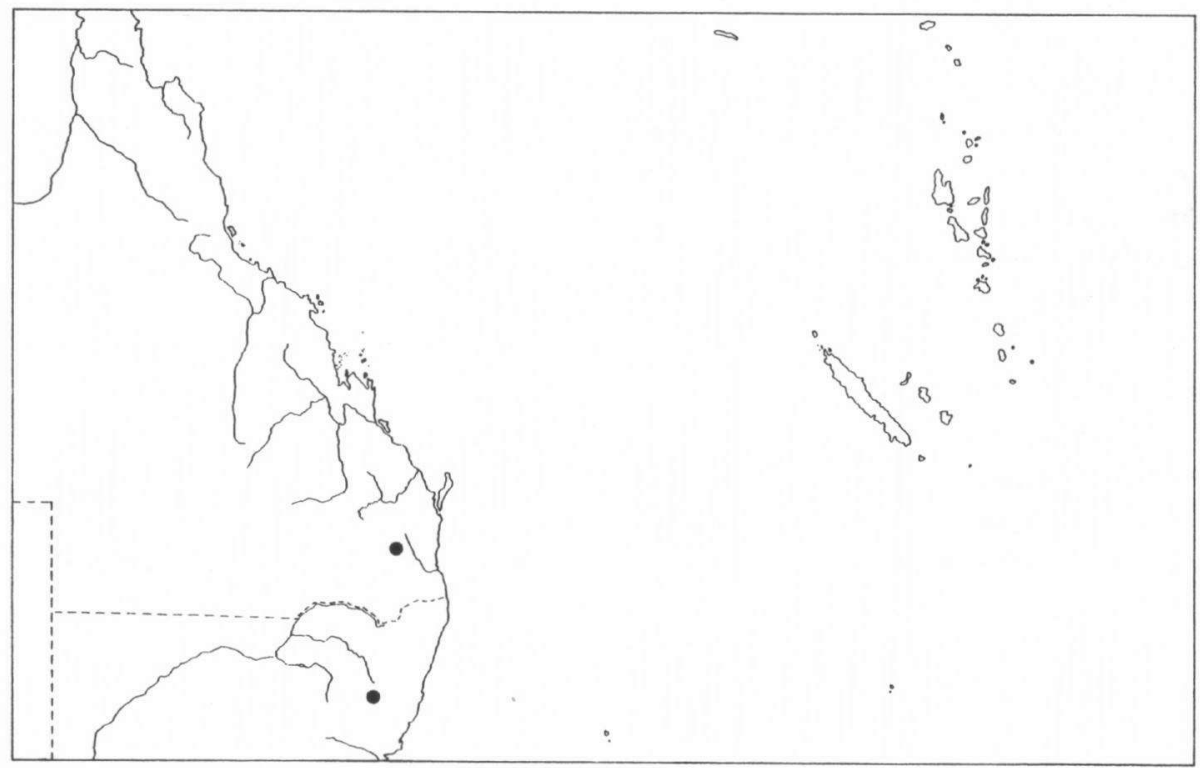

Figure 37. Megalospora australiensis, distribution.

24. Megalospora halei spec. nov.

type: Sabah, Kinabalu National Park, tourist trail between Layang Layang and Paka Cave, elev. 2700-2900 m, Hale 28671, VIII.1964 (US).

Diagnosis: Thallus flavescens, crassiusculus, rugulosus, sorediis destitutus, nonnumquam isidiis cylindricis vel coralloideis c. $0.2 \mathrm{~mm}$ latis et $1 \mathrm{~mm}$ longis provisus, acidum usnicum et zeorinum continens. Apothecia c. 2 mm lata et 650$1250 \mu \mathrm{m}$ crassa plusminusve obconica. Discus planus, fuscus, epruinosus, nitidus. Margo prominentior, crassus, fuscus, disco fuscior, epruinosus, nitidus. Epithecium diffusiter rufum, 12-20 $\mu \mathrm{m}$ crassum. Hymenium 200-270 $\mu \mathrm{m}$ crassum, I-negativum. Excipulum pallidum, $\mathbf{K}+$ flavescens. Basis apothecii 700-800 $\mu \mathrm{m}$ latus. Substantia ignota B presens et crystalla calcii-oxalatica in excipulo medullare 
provisa. Sporae singulae, bacillares, rectae (typo "tuberculosa"), e 6-8 cellulis compositae, magnitudine 120-200 x 30-45 $\mu \mathrm{m}$, septis tenuibus, pariete c. $2 \mu \mathrm{m}$ crasso et episporio $0.5 \mu \mathrm{m}$ crasso laeve. Sylvarum subalpinarum Australasiae incola.

\section{Description}

Thallus pale greenish yellow, rather thick, rugulose or irregular and following the uneveness of the substrate. Soredia absent. Isidia present in one specimen (Sipman 15967), c. $0.2 \mathrm{~mm}$ wide and $1 \mathrm{~mm}$ long, slightly coralloid-branched. Chemistry: usnic acid and zeorin.

Apothecia c. $2 \mathrm{~mm}$ diam., when young c. $1.0 \mathrm{~mm}$, and up to $3.5 \mathrm{~mm}$, c. 650-1250 fm thick and more or less obconical. Disc flat or, in larger apothecia, convex, brown, glossy. Margin rather prominent, thick, brown, usually s1ightly darker than the disc, glossy.

Epithecium diffusely orange-brown, 12-20 $\mu$ thick, in one specimen (Hale 28671) with a $15 \mu \mathrm{m}$ thick hyaline top-layer. Hymenium 200-270 $\mu \mathrm{m}$ high, I Excipulum yellowish, after acetone-washing colourless with a weakly brown ectal layer and a narrow orange-brown rim on the upper part of the ectal excipulum, $\mathrm{K}+$ yellow. Apothecium base 700-800 $\mu \mathrm{m}$ wide. Apothecium chemistry: unknown substance B. Crystals of Calcium 0xalate present in the medullary excipulum.

Spores solitary, bacillar-pluriseptate, straight, with thin septa (tuberculosa-type, P. 45 Fig. 6 C), 6-8-celled, c. 120-200 x 30-45 $\mu \mathrm{m}$. Spore wal1 c. 2 $\mu \mathrm{m}$ thick. Epispore very thin, c. $0.5 \mu \mathrm{m}$ thick, smooth.

Pycnidia not observed.

\section{Distribution and ecology}

Megalospora halei occurs in the subalpine zone of the highest mountains of Southeast Asia (fig. 38). Four specimens originate from Mount Kinabalu, Sabah, between 2700 and $3500 \mathrm{~m}$ elevation, and a single collection is from Mount Wilhelm, Papua New Guinea, at an elevation of $3800 \mathrm{~m}$. All specimens are on mossy bark. The New Guinea specimen grew on a well-illuminated treebole in subalpine woodland.

\section{Remarks}

Megalospora halei resembles most closely $M$. tuberculosa, which, however, has a lower hymenium and smaller spores. The very thick, brown apothecia of $M$. halei are distinct from the small, nearly black apothecia of most specimens of M. tuberculosa on the same localities. Only the specimens from Sarawak and New 
Guinea mentioned on p. 163 have a stronger resemblance to $M$. halei, but differ as indicated there.

The occurence of isidiate plants on Mount Wilhelm suggests that it concerns a secundary (sub-) species. However more material is necessary to prove whether the presence of isidia is a constant character of the representatives on New Guina.

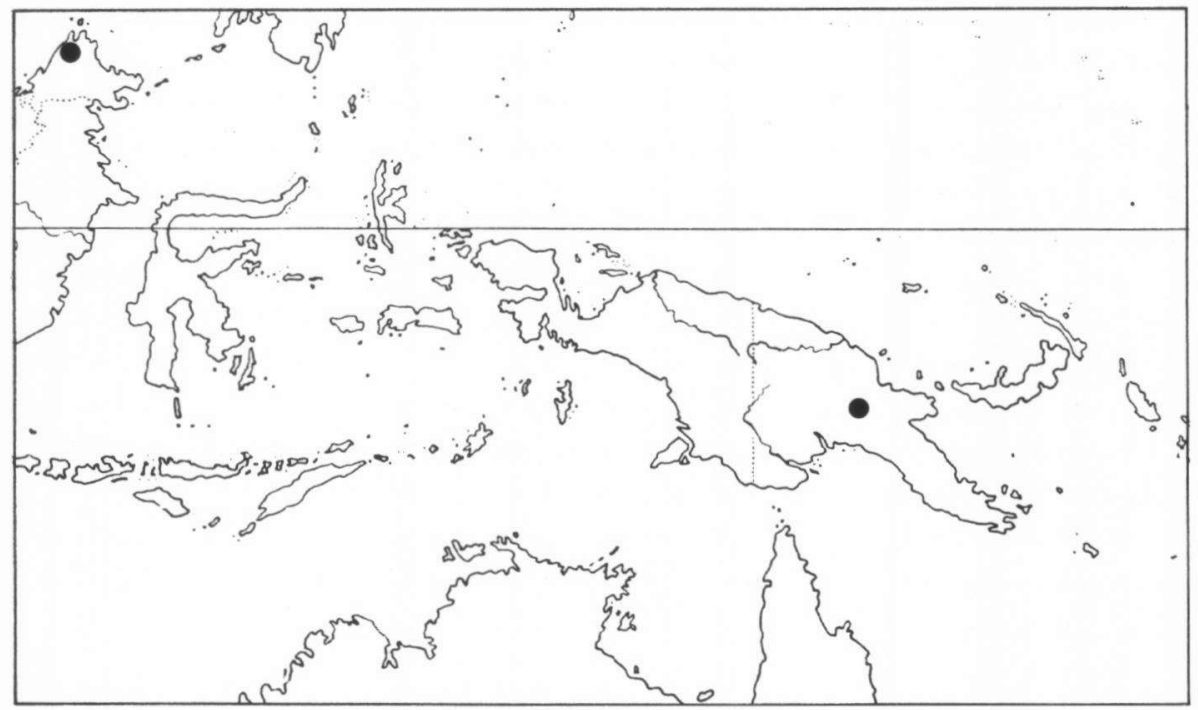

Figure 38. Megalospora halei, distribution.

25. Megalospora inflexa (Knight) comb. nov.

basionym: Lecidea inflexa KNIGHT in BAILEY, Synops. Queensland Flora, 1 supp1., p. 74 (1886).

type: Australia, Queensland, ad cortices arborum (not seen?)

NOTE. No specimens have been found with a direct indication that they belong to the original material, not even an inscription with the name Lecidea inflexa. Moreover any type specimens are difficult to recognise because the habitat information in the original description is incomplete. However in BM a specimen collected by Bailey in Queensland is present which fits the original description of Lecidea inflexa quite wel1. As it was collected by Bailey and no other 
specimen according with the original description seems to exist, it might well be the type specimen, although the only name mentioned on its label is Bombyliospora custratiensis.

synonym:

Bombyliospora inflexa (KNIGHT) A. ZAHLBR., Catal. Lich. Univ. 7: 54 (1931).

\section{Description}

Thallus pale grey, rather thick, rugulose and irregularly cracked. Isidia and soredia absent. Chemistry: pannarin and zeorin.

Apothecia c. $1.5 \mathrm{~mm}$ diam., c. $0.8 \mathrm{~mm}$ when young, and up to $2.5 \mathrm{~mm}$, c. $300 \mu \mathrm{m}$ thick. Disc flat or slight1y concave, brownish black, epruinose, slightly glossy. Margin very prominent, more or less inflexed when dry, rather thick, grey to darkgrey, epruinose, dull.

Epithecium diffusely olive-green to olive-brown, c. $10 \mu \mathrm{m}$ thick. Hymenium c. $120 \mu \mathrm{m}$ high, I + blue in the basal part and in the ascus tips. Excipulum brown with a thin red-brown subhypothecium, after acetone-washing pale brown with a thin, brown ectal layer and subhypothecium, K -. Apothecium base c. $350 \mu \mathrm{m}$ wide. Apothecium chemistry: unknown substances $A$ and $C$ ( $C$ dominant). Crystals of Calcium Oxalate in the medullary excipulum absent.

Spores solitary, bacillar-pluriseptate, straight, with thin septa (tuberculosa-type, p. 45 Fig. 6 C), 6-9-celled, 70-100 x 18-27 $\mu$ m. Spore wall not c1early observed.

Pycnidia not observed.

\section{Distribution and ecology}

Megalospora inflexa is only known from Queensland, Australia, from treebark (Fig. 39).

\section{Remark}

Megalospora inflexa differs clearly from other Megalospora species by the peculiar, concave apothecia with inflexed, grey margin. However, more material is very desirable to establish the range of variation of this species.

The only other symatric Megalospora species with tuberculosa-type spores, M. australiensis, differs clearly by the presence of algae in the excipulum, the presence of yellowish crystal aggregates in the ectal excipulum and the apothecium colour. 


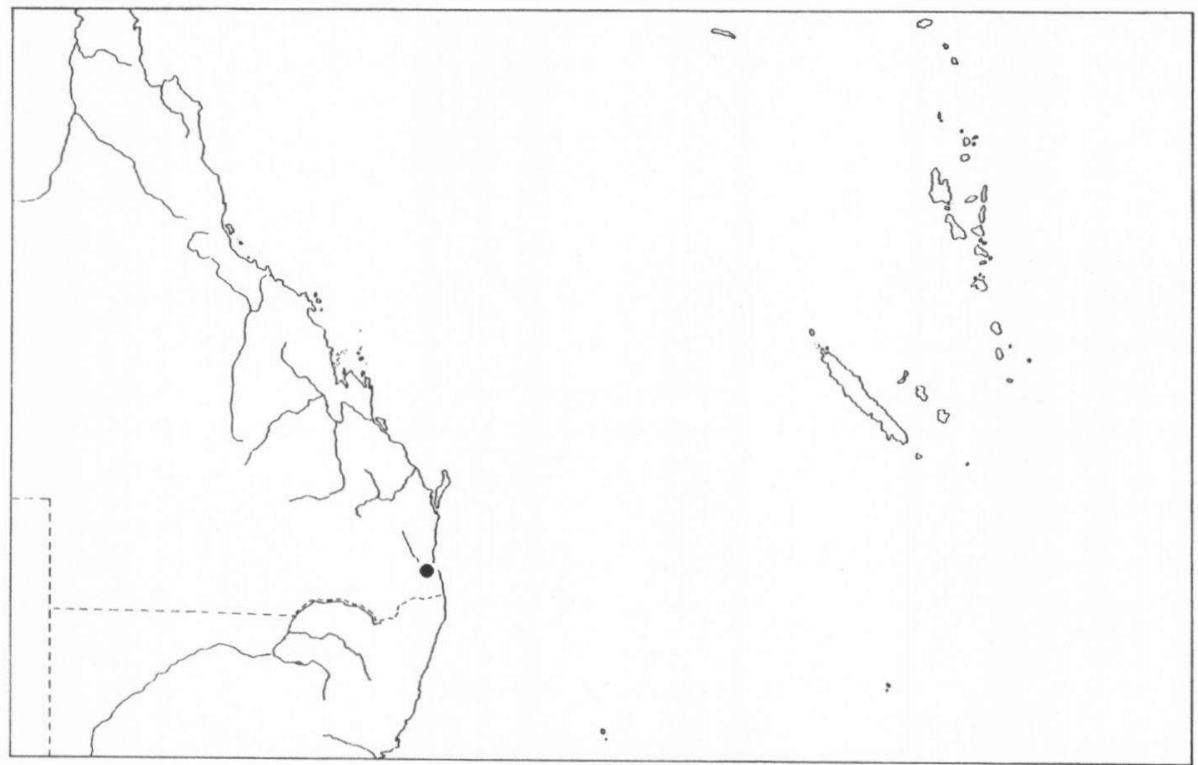

Figure 39. Megalospora inflexa, distribution.

26. Megalospora tuberculosa (Fée) comb. nov.

basionym: Lecidea tuberculosa FEE, Essai Ctyptog. Ecorc. Offic., p. 107 (1824),

type: Ad corticem cinchonarum (in America), herb. Fée, Types no. 268, larger card, larger piece of two in a row (G) LECTOTYPE NOV.

NOTE. The original collection of FEE consists of several bark fragments with the lichen, generally in poor condition. The specimen with the highest number of apothecia has been chosen as lectotype.

synonyms:

Patellaria tuberculosa (FEE) SPRENGEL, Syst. Veget. 4(1): 264 (1827); - Biatora tuberculosa (FEE) MONTAGNE, Ann. Sci. Nat., Bot., sér. 3, 10: 126 (1848); - Heterothecizon tuberculosion (FEE) FLOTOW, Bot. Zeitung 8: 555 (1850); - Bombyliospora tuberculosa (FEE) MASSALONGO, Ricerch. Auton. Lich., p. 116 (1852); - Bacidia tuberculosa (FEE) TREVISAN, Spighe e Paglie, p. 7 (1853); - Psorothecium tuberculosim (FEE) STIZENBERGER, Ber. Thätigk. St. Gallischen naturwiss. Ges. $1861-62$, p. 160 (1862).

Patellaria tuberculosa var. subversicolor MUELLER ARG., Flora 69: 307 (1886) 
(Lich. Beitr. 1029); - Bombyliospora tuberculosa var, subversicolor (MUELL. ARG.) A. ZAHLBR., Catal. Lich. Univ. 7: 57 (1931).

original material: "Corticola in Mexico prope Orizabam, F. Müller; prope Caracas, Moritz, Dr. Ernst; Brasilia, prope Apiahy, Puiggari 1028

NOTE. Only one specimen from the original material could be recognised with certainty in the collections from G. Therefore no lectotype has been selected, in attendance of more specimens becoming available.

? Patellaria tuberculosa var. aberrans MUELLER ARG., Bull. Soc. Bot. Belgique 34: 141 (1893); - Bombyliospora tuberculosa var. aberrans (MUELL. ARG.) A. ZAHLBR., Catal. Lich. Univ. 7: 57 (1931).

type: Costa Rica, Boruca, corticole, Pittier 6073 (not seen)

Lecidea tuberculosa fo. geotropa STIZENBERGER, Flora 19: 417 (1886); - Bombyliospora tuberculosa fo. geotropa (STIZENB.) A. ZAHLBR,, Catal, Lich. Univ. 7: 56 (1931).

type: South Africa, Cape of Good Hope, "Auf trockener Erde am Tafelberg", Jelinek 325 (W)

Patellaria pachycarpa DELISE apud DUBY, Botanic. Gallic. 2: 655 (1830); - Lecidea pachycarpa (DEL.) DUFOUR in FRIES, Lichenogr. Europ. Reform., p. 259 (1831); - Biatora pachycarpa (DEL.) FRIES, Lichenogr. Europ. Reform., p. 259 (1831); Bombyliospora pachycarpa (DEL.) DE NOTARIS in MASSALONGO, Ricerch. Auton. Lich., p. 115 (1852); - Bacidia pachycarpa (DEL.) TREVISAN, Spighe e Paglie, p. 7 (1853); - Megalospora pachycarpa (DEL.) OLIVIER, Expos. Lich. Ouest France 2: 41 (1900); - Bilimbia pachycarpa (DEL.) BOISTEL, Nouv. Flore Lich., 2 part., p. 191 (1903).

type: "In sylva Neustriae Fougères detexit cl. Délise" (not seen)

NOTE. Although no type for Patellaria pachycarpa has been found, the conspecificity of this species with Megalospora tuberculosa seems guaranteed by the homogeneity of the European specimens, of which many were available for study.

Biatora porphyritis TUCKERMAN, Proc. Amer. Acad. Arts \& Sci. 1: 253 (1848); Bombyliospora porphuritis (TUCK.) MASSALONGO, Atti I. R. Istit. Veneto, ser. 3, 5: 262 (1860); - Heterothecium porphyritis (TUCK.) TUCKERMAN, Synopsis Americ. Lich. 2: 56 (1888); - Heterothecium tuberculosum var, porphymitis (TUCK.) TUCKERMAN, Genera Lich., p. 174 (1872); - Bombyliospora tuberculosa var. porphymitis (TUCK.) A. ZAHLBR., Catal. Lich. Univ. 7: 57 (1931).

type: United States, New Hampshire, White Mountains, "commonest on Hemlock", E. Tuckerman, 1847, largest bark fragment (FH) LECTOTYPE NOV.

NOTE. In the herbarium of Tuckerman (FH) there are two packets of this species, one bearing the date 1856, and thus too young to be studied for the original description, and the other bearing the date 1847. The latter consists of two cards filled with bark fragments, which probaly do not belong to the same tree species. The largest fragment of them is chosen as lectotype.

Lecidea meZanocarpa NYLANDER, Ann. Sci. Nat., Bot., ser. 4, 11: 260 (1859) SYN. NOV.; - Bombyliospora melanocarpa (NYL.) MASSALONGO, Atti I. R. Instit. Veneto, ser. 3, 5: 262 (1860); - Patellamia melanocarpa (NYL.) MUELLER ARG., Flora 65: 330 (1882) (Lich. Beitr. 435).

type: Mascarene Islands, La Réunion ("Borbonia"), Boivin (H-Ny1. 18090)

? Bombyliospora me Zanocarpa var. Zeprosa DES ABBAYES, Bull. Instit, franc. Afrique Noire, sér. A, Sci. Nat. 17: 985 (1955)

type: Guinea, Sérédou, cercle de Macenta, tronc d'arbre en fôret claire, vers 
$860 \mathrm{~m}$, Des Abbayes, 1951 (not seen)

Lecidea chloritis TUCKERMAN apud NYLANDER, Ann. Sci. Nat., Bot,, sér. 4, 11: 260 (1859); - Patellaria chloritis (TUCK.) MUELLER ARG., Flora 64: 232 (1881) (Lich. Beitr. 300); - Bombyliospora chloritis (TUCK.) A. ZAHLBR., Denkschr. math.-naturwiss. Classe Kais. Akad. Wissensch. Wien 83: 130 (1909). type: In montibus Cubae ins. ( $\mathrm{H}-\mathrm{Ny} 1,18128)$

? Lecidea expansa FEE, Bull. Soc. Bot. France 20: 317 (1873) (nom. inval., non Chev, 1826 nec Nyl. in Leight. 1854); - Bomby Ziospora expansa (FEE) A. ZAHLBR., Catal. Lich. Univ. 7: 53 (1931).

type: Brasil, Glaziou 3230 (not seen)

? Bombyliospora meyeri STEIN, 66 Jahresber. Sch1es. Ges, vater1. Kultur, p. 139 (1889); - Patellaria meyeri (STEIN) MUELLER ARG., Flora 73: 343 (1890); Lecidea meyeri (STEIN) STIZENBERGER, Ber. Thätigk. St. Gallischen naturwiss. Ges. $1889-90$, p. 159 (1891).

type: Tanzania, Usambara, an Rinden in Hundu, H. Meyer (not seen)

Lecidea nigrata (MUELLER ARG.) VAINIO, Acta Soc. Fauna F1. Fennica 7 (2): 32 (1890); - (basionym:) Patellaria chloritis var. nigrata MUELLER ARG., Flora 64: 232 (1881) (Lich. Beitr. 300); - Bombyliospora tuberculosa var. nigrata (MUELL. ARG.) A. ZAHLBR., Sitzungsber. Kais. Akad. Wiss. Wien, math.-naturw. Classe 111(1): 398 (1902); - Bombyliospora nigrata (MUELL. ARG.) VAINIO, Ann. Acad. Scient. Fenn., ser. A, 15(6): 103 (1921).

type: Brasil, Apiahy, Puiggari 1027, XII.1879 (G)

NOTE. MUELLER ARG. mentions only two specimens in his original description. The one with better apothecia is chosen here as lectotype.

Lecidea nigrata var. phaeospora VAINIO. Acta Soc. Fauna F1. Fenn. 7(2): 32 (1890) SYN. NOV.; - Bombyliospora nigrata var. phaeospora (VAIN.) A. ZAHLBR., Catal. Lich. Univ. 7: 55 (1931).

type: Brasil, Minas Geraes, Sitio, Vainio, Lich. Bras. Exs. 573 (TUR-Vainio 22099).

Patellaria granularis MUELLER ARG., Nuovo Giorn. Bot. Ital. 23: 127 (1891) SYN. NOV.; - Bombyliospora granularis (MUELL. ARG.) A. ZAHLBR., Bot. Mag. (Tokyo) 41: 360 (1927).

type: Japan, Tosa, comm. Yataba, M. Myoshi 24, 1890 (G) LECTOTYPE NOV.

NOTE. MUELLER ARG. (1891) mentions two specimens, Myoshi 8 and 24. The second one is considered here to be the type because $i$ ts label bears the addition "orig.", and the label of the other specimen "vetustior".

? Lecidea endoleucitis STIRTON, Proc. Trans. New Zealand Inst. 30: 387 (1898);

- Bomby Ziospora endoleucitis (STIRTON) A. ZAHLBR., Catal. Lich. Univ. 7: 53 (1931).

type: West Tropical Africa (Cameroun?), Victoria, hb. Stirton (not seen)

Bombyliospora zuluensis VAINIO, Ann. Univ. Fenn. Aboensis, ser. A, 2(3): 18 (1926) SYN. NOV.

Lectotype: Ad corticem Thespesiae prope Eshore in Zululand, v. d. Bij1 184

(TUR) (according to a slip on the specimen selected by 0. Almborn, 1982)

? Bombyliospora japonica A. ZAHLBR., Bot. Mag. (Tokyo) 41: 359 (1927).

Original material: Japan, Liukiu, Yakushima, Faurie 2427; Rikutschiu, Hajatsch- 
ine, Faurie 6585 (not seen).

? Bombyliospora japonica fo. cinerea A. ZAHLBRUCKNER, Bot. Mag. (Tokyo) 41: 359 (1927).

Type: Japan, Yeso, Yakumo, Faurie 6368 (not seen)

? Bombyliospora japonica fo, purpurascens ASAHINA, J. Jap. Bot, 20: 133 (1944). original material: Japan, Kiushiu (Yakushima, Higo); Sikoku (Iyyo, Tosa); Hondo (Idzu, Suruga, Musasi, Bôsiu) (not seen)

Bomby liospora sinensis A. ZAHLBRUCKNER apud HANDEL-MAZETTI, Symb, Sinic. 3: 212-213 (1930) SYN. NOV.

type: China, prov. Hunan austro-occ., in monte Yün-schan prope urbem Wukang .., alt. $1350 \mathrm{~m}$, Handel-Mazetti, Iter sin. 1914-18 nr. 12082 (W) LECTOTYPE NOV.

NOTE. Among the collections cited in the original description this lectotype has been selected because it is the largest specimen. Nr. 12166 is erroneously included in the description, because it is in fact a Bacidia species.

? Bombyliospora buelliacea A. ZAHLBRUCKNER, Fedde Repert. 33: 63 (1933). original material: Taiwan, Rengechi, ad cortices, Asahina 157 (juv.); Toroyen, Asahina 183 (not seen)

? Bomby Ziospora asahinae SATo, J. Jap. Bot. 11: 636 (1935); - Bomby Ziospora japonica fo, asahinae (SATO) ASAHINA, J. Jap. Bot. 20: 133 (1944)

type: Ad cortices arborum, in monte Minobu, prov. Kai, Asahina 231, 11.vIII. 1922 (not seen)

? Bombyliospora asahinae fo. nuda SATo, J. Jap. Bot. 11: 636 (1935)

type: Ad cortices arborum, in monte Osorezan, prov. Mutsu, M. M. Sato 202, 30.v.1935 (not seen)

? Bomby Ziospora subnigrata YASUDA ex RAESAENEN, J. Jap. Bot. 16: 152 (1940) type: Japan, prov. Koluze, ad corticem Pini densiflorae, Yasuda 699 (not seen)

? Bombyliospora angela HERRE, Bryologist 54: 286 (1951)

type: Ad truncos arborum, Mons Angelo, prov. Tayabas, Luzon, Philippines, A. W. C. T. Herre, 17.II.1923 (not seen)

? Bomby Ziosporomyces tuberculosae CIFERRI \& TOMASELLI, Atti Istit. Bot. Univ. Lab. Crittog. Pavia, ser. 5, 10:63 (1953) (nom. inval.)

type: (no description or type given)

? Bombylios pora Zaevigata AWASTHI \& AGARWAL, Canad. J. Bot. 46: 1029 (1968) type: India, Darjeeling distr., at 7-8 mi on Pashok road from Darjeeling, alt. c. $1800 \mathrm{~m}$, D. D. Awasthi \& M. R. Agarwal 67.147 , 6.III.1967 (not seen)

NOTE. Although of many of the taxa listed above no type material has been seen, their inclusion in Megalospora tuberculosa seems justified because of their original descriptions and in accordance with the identity of investigated specimens from the same areas where the types originate from. 


\section{Description}

Thallus pale yellowish grey, rather thin, smooth to rugulose or sometimes nearly granular (with c. 0.1-0.2 mm wide granules), sometimes with 0.4-0.6 mm wide tubercles. Soredia occasional, 30-80 $\mu$ mide, produced in soralia developed from low warts. Isidia absent. Chemistry: strain A, usnic acid (sometimes in very small amounts or perhaps absent) and zeorin; strain $B$, pannarin and zeorin, occasionally with unknown substance $B$ in tubercles.

Apothecia c. $1.5 \mathrm{~mm}$ diam., 0.6-1.0 $\mathrm{mm}$ when young, and up to $2.8(-4) \mathrm{mm}, 380-$ $580 \mu \mathrm{m}$ thick. Disc flat or, in the largest apothecia, convex, brown to black, slightly to clearly glossy, occasionally pruinose and then dull. Margin more or less prominent, rather thin, darkbrown to black, with pigment sometimes limited to the upper part, slightly to clearly glossy.

Epithecium diffusely olive-green to -brown or black, or orange-brown to brown, sometimes with a granular top-layer which disappears in lactophenol-cottonblue preparations, 12-15(-18) $\mu \mathrm{m}$ thick. Hymenium 130-185(-210) $\mu \mathrm{m}$ high, I or $I+$ blue in the asci, rarely also in the basal part of the hymenium.

Excipulum pale yellowish to darkbrown, often more pigmented in the upper part, when pale sometimes with a thin orange-brown layer in the subhypothecium, or with a dark subhypothecium, $\mathrm{K}$ - or $\mathrm{K}+$ weakly reddish or yellowish. Apothecium base 200-400(-550) $\mu m$ wide. Apothecium chemistry: strain I, unknown substances $A$ and $C$, in variable amounts, of ten in traces; strain II, unknown substance B; strain III, unknown substance A, B and C; strain IV, no demonstrable substances. Crystals of Calcium Oxalate sometimes present in the medullary excipulum.

Spores solitary, bacillar-pluriseptate, straight, with thin septa (tubercu-

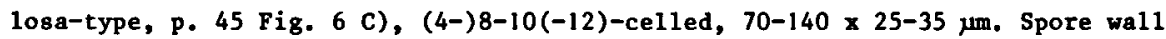
c. $2 \mu \mathrm{m}$ thick. Epispore indistinct, c. $0.5 \mu \mathrm{m}$ thick, smooth.

Pycnidia not observed.

\section{Distribution and ecology}

Megalospora tuberculosa is the most widely distributed species of the genus. In America it ranges from the United States to Southern Brasil, in Eurasia from Western Europe to Japan and New Guinea, and in Africa from the Canary Islands to the Mascarene Islands and South Africa (Fig. 40). In tropical regions the species inhabits mainly mountains, but does occur also at rather low elevations, e.g. at $70 \mathrm{~m}$ on Trinidad. In Papua New Guinea it has been found at elevations ranging from 1600 to $4450 \mathrm{~m}$, in dense forests on canopee branches or on shrubs in clearings, in subalpine forest on less exposed branches, and in alpine situ- 
ations on low branches of darfshrubs or on mossy sheltered rockfaces. In the neotropics Megalospora tuberculosa is a rather common species, more frequent than Megalospora sulphurata and less restricted in altitudinal zonation. Probably it is more tolerant to disturbence of its habitat.

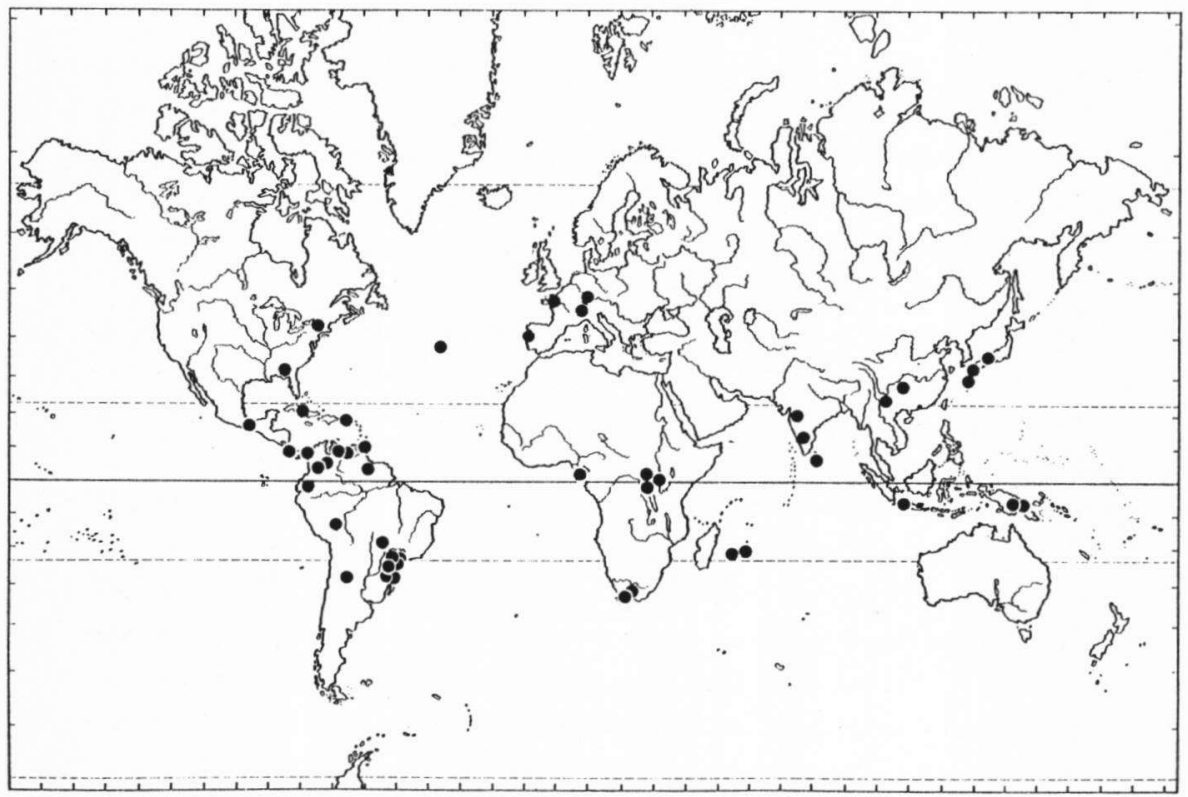

Figure 40. Megalospora tuberculosa, distribution.

\section{Remarks}

By its tuberculosa-type spores Megalospora tuberculosa resembles most close1y $M$. albescens, $M_{0}$ australiensis, $M$. halei and $M$. inflexa. The differences with these species are treated in extenso under their descriptions. The most clear differences are: $M$. albescens has over $150 \mu \mathrm{m}$ long spores; $M$. australiensis contains algae in the medullary excipulum; $M$. halei has an over $200 \mu \mathrm{m}$ high hymenium; and $M$. inflexa has an inflexed, bluish-grey apothecium margin.

The presence of tubercles is very variable. Sometimes they are very clear and dense, sometimes scattered, or unclear and hardly or not distinct from the usual rugulosity of the thallus.

In accordance with its large range, $M$. tuberculosa is a very variable spe- 
cies. The local populations in the various parts of the world show conspicuous differences, but none of these is considered suitable to distinguish any taxa. Either the character states pass gradually into eachother, or they occur mixed in populations or in several unconnected parts of the range of the species.

The specimens from Europe and the Canary Islands show a constantly orangebrown epithecium, a high frequency of soredia, presence in the apothecia of unknown substance $B$ only, and a complete absence of tubercles.

The neotropical material resembles the European specimens much, but is usually esorediate. The occurence of tubercles is rather frequent, but by no means constant. The apothecia are usually brown to darkbrown with an orange-brown epithecium. The occasional occurence of black apothecia is usually not in connection with an olive-brown to black epithecium, as in other parts of the world, but with a darkbrown subhypothecium, a feature that is rare else. Most specimens contain usnic acid, but a number of specimens from southern Brasil, the Caribbean region and the United States contain pannarin. Substances $A$ and $C$ are the most widely distributed apothecium substances, but in specimens from the Caribbean region, from Colombia and Venezuela to the United States, substance $B$ is frequent. Such specimens have often a remarkably pale apothecial margin, and in some of them substance $B$ has been found also in the tubercles of the thallus, which have a yellow medulla contrasting with the white medulla of the remaining thallus, then (e.g. the type of Lecidea chloritis). Neotropical plants with an olivaceous epithecium are rare, having been collected from Costa Rica (Sipman 11960) and Venezuela (Steyermark \& Nilsson C41).

A remarkable population occurs in the Northeastern United States (Massachusetts, New Hampshire, Vermont). It shows whitish-grey, pannarin-containing thalli with small soralia developing on low warts and producing c. $30 \mu \mathrm{m}$ wide soredia. The apothecia are of a dark colour and frequently pruinose. This population has been described as Biatora porphyritis by TUCKERMAN (1848). However it does not show any character that is not represented in other populations of the species: pannarin does occur in East Asian, Southern Brasilian and Caribbean populations; soralia occur in European, African, Asian and Central American plants; dark-coloured apothecia are rare on the American continent, but common in Asia; pruinose apothecia occur in Japan. The overall similarity of the Northeastern USA-plants is greatest with the Japanese population, which suggests that the occurence might be a relic of a former larger range connecting East Asia with North America.

Specimens from continental Africa and eastwards to India, show a high fre- 
quency of olivaceous to black pigmentation of the epithecium, and correspondingly black apothecia. The thallus is frequently rather uneven, warted or granular, but rarely with tubercles. One specimen from India (Hale 43859) has isidia-like structures: the thallus is warted, and some of the warts are elongated and coralloid-branched, but they remain shorter than true isidia in e.g. Megalospora sulphurata. Another specimen from India (Anstead s.n.) is sorediate. Specimens from Northern India with a smooth thallus have been described as a distinct species, Bomby Ziospora Zaevigata. The original description suggests that they contain pannarin, and they probably resemble the chinese representatives of $M$. tuberculosa, which equally have a smooth thallus.

Specimens from Papua New Guinea have mostly an olivaceous to black epithecium and black apothecia. Soredia have not been found and the unknown substances in the apothecia are usually lacking. The specimens from Indonesia and Sabah agree mostly with those from New Guinea.

Remarkable are two specimens from Sarawak (Coppins 5000 and 5001) and one from New Guinea (Sipman 16036d) which differ from the other plants of $M$. tuberculosa in these areas by the occurence of 4-6-celled spores and of unknown substance $B$. In the latter respect they resemble $M$. halei, which differs by its larger spores, higher hymenium, thicker apothecia and 6-8-septate spores. Perhaps they deserve an independent taxonomic rank, but in the absence of clear key characters and because of the small number of available specimens they are provisionally placed in $M$. tuberculosa.

The single specimen available from Madagascar (Perville 870) shows crystals in the top of the ectal excipulum. Perhaps this is an artifact, because the specimen is in poor condition.

A very distinct population occurs in Japan and China, and according to the literature also on Taiwan. Its most conspicuous character is the constant presence of pannarin instead of usnic acid. The thallus is of ten granular. The dimensions of apothecia and spores are generally smaller, and in Japan the apothecia are frequently pruinose. These characters suggest that this East Asian population shows a sufficient genetical isolation to deserve the rank of subspecies. However no key character is available.

No specimens of the present species have been found from the area South of New Guinea (Australia, New Caledonia, New Zealand). A specimen from New Zealand (Sinclair s.n.), identified as Biatora pachycarpa (BABINGTON 1855), proved to belong to Megalospora knightii. 
27. Megalospora kalbil spec. nov.

type: Argentina, Rio Negro, oberhalb von Llao Llao, etwa $25 \mathrm{~km}$ NW von San Carlos de Bariloche, in einem dichten Nothofagus-wald, 1250 m, Kalb 8.n., 31.XII. 1980 (hb. Kalb)

Diagnosis: Thallus pallescens, tenuis, laeviter rugulosus, isidiis sorediisque destitutus, pannarinum et zeorinum continens. Apothecia c. $1.0 \mathrm{~mm} 1$ ata et 0.45 mm crassa. Discus convexus, fuscus, epruinosus, opacus, in apotheciis juvenilibus planus et laeviter albo-pruinosus. Margo tenuis, haud pruinosus, fuscus, epruinosus, nitidus. Epithecium diffusiter rufum, c. $25 \mu \mathrm{m}$ crassum. Hymenium c. $160 \mu \mathrm{m}$ crassum, I + paullo coerulescens tantum in parte basali et circum apicibus ascorum. Excipulum pallide flavum, margine tenui fusco in parte ectale proviso, K-negativum. Basis apothecii c. $370 \mu \mathrm{m}$ latus. Substantiae ignotae et crystalla calcii-oxalatica absentes. Sporae singulae, muriformes (typo "lopadioides"), e c. 24 × 6 × 6 cellulis compositae, magnitudine c. 90 x $30 \mu \mathrm{m}$, pariete $1 \mu \mathrm{m}$ crasso, sine episporio. Sylvarum Nothofagi in montibus Andium Argentinae incola.

\section{Description}

Thallus whitish, thin, slightly rugulose. Soredia and isidia absent. Chemistry: pannarin and zeorin.

Apothecia c. $1.0 \mathrm{~mm}$ wide, c. $0.5 \mathrm{~mm}$ when young, and up to $1.3 \mathrm{~mm}, \mathrm{c} .0 .45 \mathrm{~mm}$ thick. Disc convex, brown, epruinose, dull, in young apothecia flat and slightly whitish-pruinose. Margin thin and not prominent, brown, concolorous, epruinose, slightly glossy.

Epithecium diffusely orange-brown, c. $25 \mu \mathrm{m}$ thick. Hymenium c. $160 \mu \mathrm{m}$ high, I - but lower part of hymenium and ascus tips weakly I + blue. Excipulum pale yellow with a thin brown margin on the ectal excipulum, $K-$. Apothecium base c. $370 \mu \mathrm{m}$ wide. Apothecium chemistry: no detectable substances. Crystals of Calcium Oxalate equally absent.

Spores solitary, muriform and with thin septa (lopadioides-type, p. 45 Fig. $6 \mathrm{H}$ ), composed of c. $24 \times 6 \times 6$ cells, c. $90 \times 30 \mu \mathrm{m}$. Spore wall c. $1 \mu \mathrm{m}$ thick, without clear epispore.

Pycnidia not observed.

\section{Distribution and ecology}

The only available specimen originates from Nothofagus-forest in the Andes of central Argentina (Fig. 41), found on smooth bark and accompanied by hepatics (Frulzania sp. and Lejeumeaceae). 


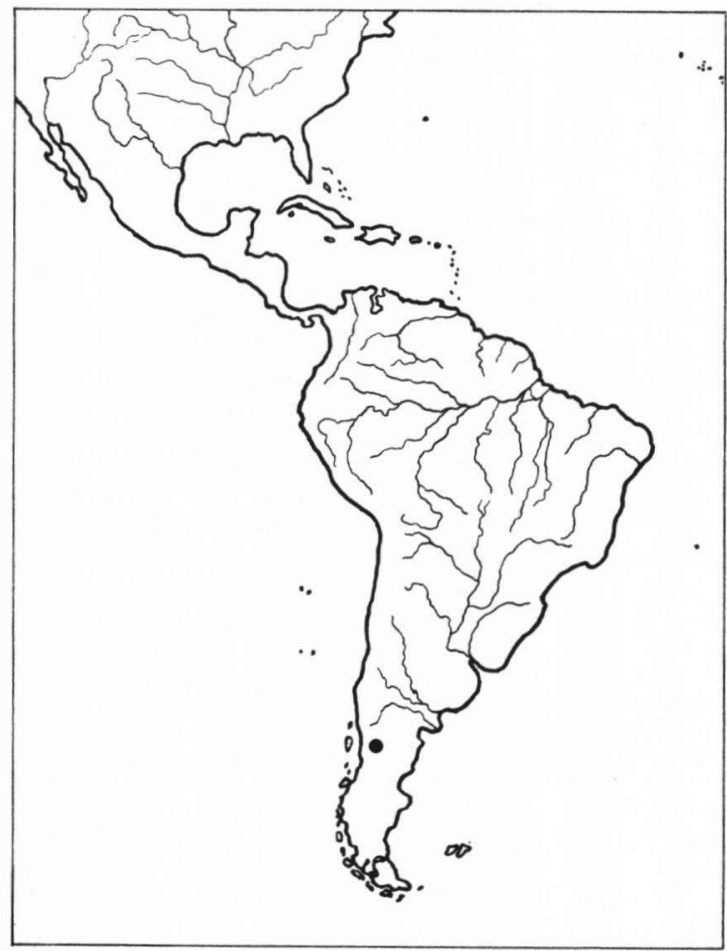

Figure 41. Megalospora kalbii, distribution.

\section{Remark}

By its lopadioides-type spores Megalospora kalbii resembles $M$. Lopadioides from Tasmania and West Australia, and $M$. queenslandica from Queensland. From the former it differs by its small, soon convex apothecia with thin margin and pale excipulum, from the latter by the presence of pannarin in the thallus, the pruinose young apothecia and the small spores.

28. Megalospora lopadioides spec. nov.

type: Australia, Tasmania, Lake Judd Forest, elev. 640 m, Bratt 73/917, 28. VIII. 1973 (HO) 
Diagnosis: Thallus albicans, crassiusculus, rugulosus, sorediis isidiisque destitutus, pannarinum zeorinumque continens. Apothecia c. $1.3 \mathrm{~mm}$ lata et c. 410 $\mu \mathrm{m}$ crassa, vetusta c. $2 \mathrm{~mm}$ lata frequenter regenerata et e choro apotheciculorum composita. Discus planus, fuscus vel niger, epruinosus, nitidiusculus. Margo prominens, niger, epruinosus, nitidus, in apotheciis maioribus flexuosus. Epithecium diffusiter olivaceum, 15-18 $\mu \mathrm{m}$ crassum. Hymenium 95-160 $\mu \mathrm{m}$ crassum, $I+$ coerulescens (praecipue ascis). Excipulum olivaceo-flavum vel -fuscum, strato externo cyaneo et subhypothecio rufo provisum, $K+f l$ avescens. Basis apothecii c. $450 \mu \mathrm{m}$ latus. Substantia ignota B, nonnumquam paulum, presens, crystalla calcii-oxalatica destituta. Sporae singulae, muriformes, tenuiseptatae (typo "lopadioides"), e 10-25 × 5-8 × 5-8 cellulis compositae, magnitudine 60-90 × 25-35 m, pariete 1 m crasso, episporio obscuro, septis c. 0.5 $\mu \mathrm{m}$ crassis. Sylvarum humidarum Australiae australis incola.

\section{Description}

Thallus pale grey to whitish, rather thick and cracked, rugulose. Soredia and isidia absent. Chemistry: pannarin and zeorin.

Apothecia c. $1.3 \mathrm{~mm}$ diam., c. $0.7 \mathrm{~mm}$ when young, and up to $2.3 \mathrm{~mm}$ but then usually regenerated into a group of small apothecia, c. $410 \mu \mathrm{m}$ thick. Disc flat, brown to black, epruinose, slightly glossy. Margin prominent, in larger apothecia flexuose, black, epruinose, glossy.

Epithecium diffusely olive-green, 15-18 $\mu \mathrm{m}$ thick. Hymenium 95-160 $\mu \mathrm{m}$ high, I + dark blue (mainly caused by staining of the asci). Excipulum olive-yellow or olive-brown, with a thin blue-green margin on the ectal excipulum and an orange-brown subhypothecium, $\mathrm{K}+$ yellowish. Apothecium base c. 450 jm wide. Apothecium chemistry: unknown substance $B$ in variable amounts, sometimes (nearly) absent. Crystals of Calcium Oxalate usually absent.

Spores solitary, muriform with thin septa (lopadioides-type, p. 45 Fig. $6 \mathrm{H}$ ), composed of c. $10-25 \times 5-8 \times 5-8$ cells, $60-90 \times 25-35 \mu \mathrm{m}$. Outer spore wall c. $1 \mu \mathrm{m}$ thick, without clear epispore, smooth. Septa c. $0.5 \mu \mathrm{m}$ thick.

Pycnidia not observed.

Distribution and ecology

The present species is only known from Australia, from Tasmania and West Australia (Fig. 42), at elevations between 300 and $800 \mathrm{~m}$. One specimen was collected on a thin treetrunk in a clearing in low Nothofagus forest, another one on thin treetrunk along a stream in a deep gorge.

\section{Remarks}

Megalospora lopadioides is well characterised by its thin-septate, muriform spores. Only two other Megalospora species show such spores, M. queenslandica, 
which differs by the larger size of its spores, c. $115 \times 36 \mu \mathrm{m}$, by the absence of pannarin and the presence of usnic acid instead, and by the presence of unknown substances $A$ and $C$ in the apothecium, and $M$. kalbii, which differs by its small, convex, pale apothecia which are pruinose when young.

A certain resemblance exists also with the genus Brigantiaea, in spore form and apothecium structure, but this genus differs clearly by the presence of $\mathrm{K}+$ purple substances in the epithecium.

The specimen from West Australia is slightly deviating by its conical apothecia containing large amounts of crystals of Calcium Oxalate. Moreover its

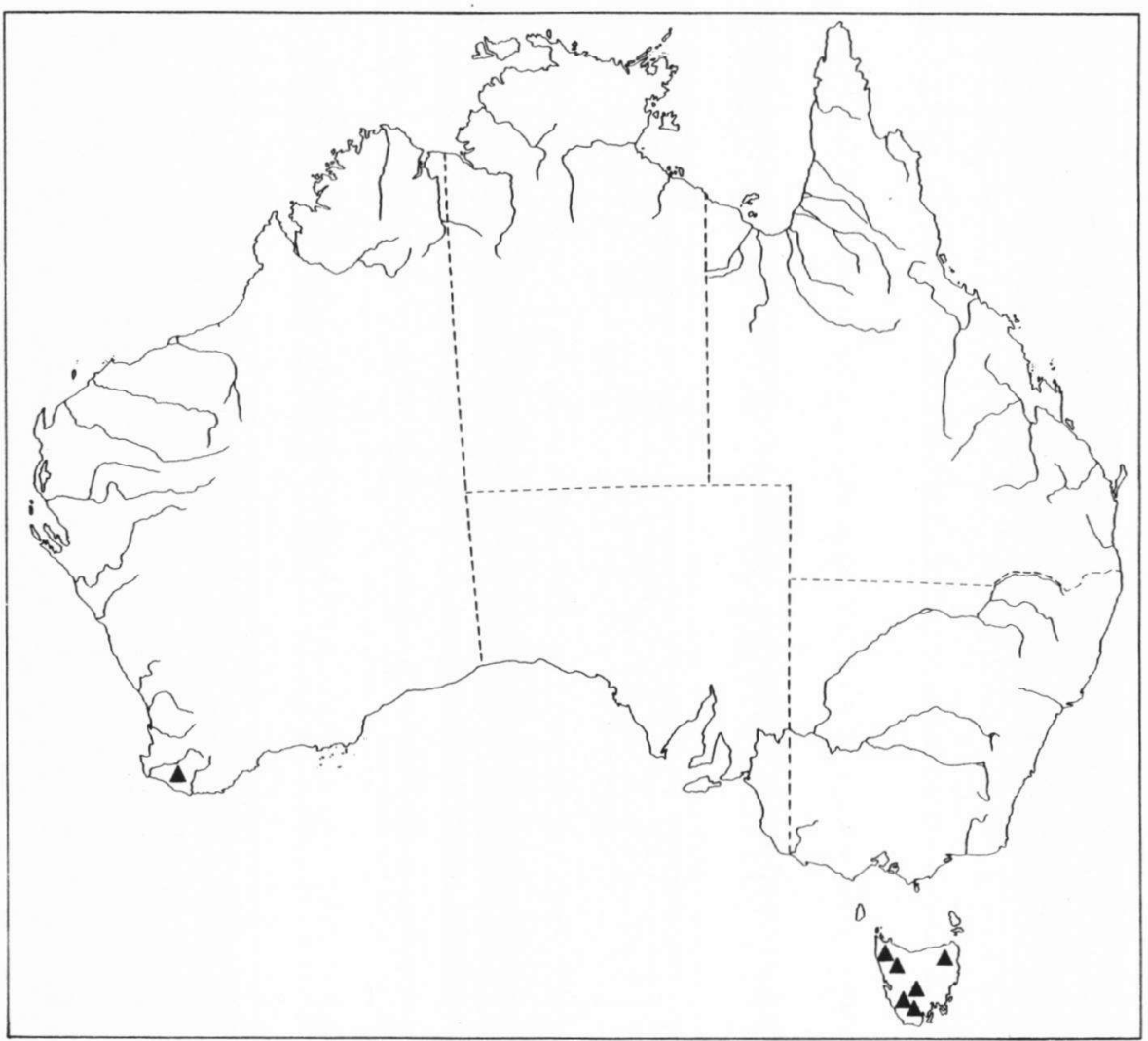

Figure 42, Megalospora lopadioides, distribution. 
apothecium margin is brown, not black.

A conspicuous feature of Megalospora Lopadioides is the high frequency of degenerated apothecia: nearly all apothecia of over $1.5 \mathrm{~mm}$ diam, were largely degenerated with young, small apothecia on top of the remains of the old one. Such clusters of young apothecia have been used to distinguish $M$. Zopadioides in the herbarium from $M$. gompholoma macroscopically.

\section{Megalospora queen slandica spec. nov.}

type: Australia, Queensland, Atherton Scrub, R. Mitchell, VIII.1911 (NSW).

Diagnosis: Thallus flavescens, sorediis isidiisque destitutus, acidum usnicum et zeorinum continens. Apothecia c. 1 mm lata et c. 450 um crassa. Discus planus vel leviter convexus, fuscus, epruinosus, nitidiusculus. Margo tenuis, paulo prominens, fuscus, epruinosus, nitidiusculus. Epithecium rufes-

cens, c. 10 um crassum. Hymenium c. 140 um crassum, basin versus et ascis $I+$ coerulescens. Excipulum pallidum, K-negativum. Basis apothecii c. 370 um latus. Substantiae ignotae A (dominans) et C presentes. Crystalla calcii-oxalatica destituta. Sporae singulae, muriformes (typo "lopadioides"), e c. $20 \times 6$ x 6 cellulis compositae, magnitudine c. $115 \times 36 \mathrm{~mm}$, septis tenuibus et pariete c. $2 \mu \mathrm{m}$ crasso, episporio c. I $\mu \mathrm{m}$ crasso laeve. Australiae incola.

\section{Description}

Thallus yellow-grey, rather thin, rugulose, irregularly cracked. Soredia and isidia absent. Chemistry: usnic acid and zeorin.

Apothecia c. $1 \mathrm{~mm}$ diam., 0.5-0.6 mm when young, and up to $1.5 \mathrm{~mm}$, c. $450 \mu \mathrm{m}$ thick. Disc flat, in larger apothecia slightly convex, brown to dark-brown, epruinose, slightly glossy. Margin hardly prominent, thin, dark-brown, darker than the disc, epruinose, slightly glossy.

Epithecium diffusely orange-brown, $10 \mu \mathrm{m}$ thick. Hymenium c. $140 \mu \mathrm{m}$ high, I + blue in its basal part and the asci. Excipulum pale, $\mathrm{K}-$. Apothecium base c. $370 \mu \mathrm{m}$ wide. Apothecium chemistry: unknown substances $A$ (dominant) and $C$. Crystals of Calcium Oxalate absent from the medullary excipulum.

Spores solitary, muriform (lopadioides-type, p. 45 Fig. $6 \mathrm{H}$ ), composed of c. $20 \times 6 \times 6$ cells, c. $115 \times 36 \mu \mathrm{m}$. Spore wall c. $2 \mu \mathrm{m}$ thick. Epispore c. $1 \mu \mathrm{m}$ thick, smooth.

Pycnidia not observed.

Distribution and ecology

The only available specimen originates from northern Queensland, Australia (Fig. 43), from Atherton Scrub, which locality is in all likelyhood situated on 
the Atherton P1ateau, which has an elevation of c. $1000 \mathrm{~m}$. The specimen must be taken from a rather large trunk with smooth bark, because it consists of a large piece of bark.

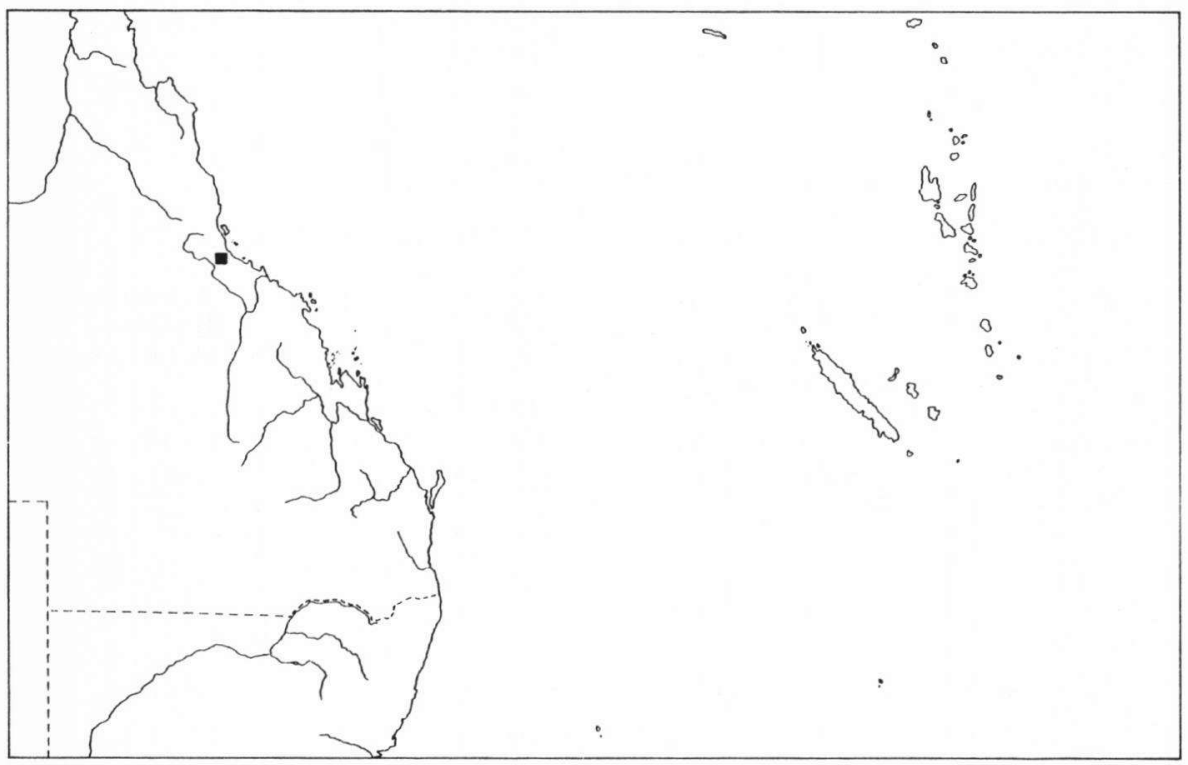

Figure 43. Megalospora queenstandica, distribution.

\section{Remarks}

The present species resembles most closely $M$. kalbii and M. Zopadioides by the presence of lopadioides-type spores. Although it is represented by a single specimen only, it has been described as a new species because it shows several clear differences from both species: presence of usnic acid; presence of unknown substances $A$ and $C$ in the apothecia; larger spores, c. $115 \mu \mathrm{m}$ long. Moreover the apothecia have a very different external appearence. 


\section{chapter 8. EXCLUDED SPECIES AND NOMINA DUBIA}

\section{A. Species formerly included in Bombyliospora}

Apart from the species now included in Megalospora, a number of other species have been included in Bombyliospora, mainly by ZAHLBRUCKNER (1931):

\section{Letrouitia}

Investigation of a few specimens of "Bombyliospora" domingensis (Pers.) Zahlbr, revealed that they differ considerably from Megalospora by the absence of oil droplets in the hymenium, the rather small spores and the low hymenium. This species and relatives have been investigated by HAFELLNER \& BELLEMERE (1982) and placed in a separate genus Letrouitia. This concerns the following species which have therefore been excluded from this study: Bombyliospora aureola (Tuck.) A. Zahlbr., B. cerinella A. Zahlbr., B. domingensis (Pers.) A. Zahlbr., B. flavidula (Tuck.) A. Zahlbr., B. flavocrocea (Nyl.) Massal., B. gyrosa (Spreng.) Massal., B. Zeprolyta (Nyl.) A. Zahlbr, and B. nigeriensis Dodge.

"Bomby Ziospora" diplotypa (VAINIO) A. ZAHLBR., Catal. Lich. Univ. 7: 50 (1931). basionym: Lecidea dip Lotypa VAINIO, Acta Soc. Fauna F1. Fenn. 7(2): 30 (1890). original material: Brasil, Minas Gerais, Carassa, E. A. Wainio, Lich. Bras. Exs. 1337, 1569 (TUR).

Investigation of the original material has shown that this species accords with the genus Bilimbia because of its spore dimensions.

"Bombyliospora" dolichospora (NYL.) A. ZAHLBR., in SKOTTSBERG, Nat. Hist. Juan Fernandez 2: 394 (1924)

basionym: Lecidea dolichospora NYLANDER, Ann. Sci. Nat., Bot., sēr. 4, 3: 162 (1855)

type: Ad corticem Xanthoxyli in ins, Juan Fernandez, hb. Delessert (not seen)

According to the spore information in the original description this species accords with the genus Bilimbia.

"Bombyliospora" incana(L.) A. L. SMITH, Monogr. Brit. Lich. 2: 198 (1911)

basionym: Byssus incana L., Spec. Plant., ed. 3, 2: 1639 (1764) 
SMITH \& SOWERBY (1807) stated to have found the fruits of this species, presently placed in Lepraria, but this was apparently based on a confusion with Megalospora tuberculosa.

"Bombyliospora" neocaledonica RAESAENEN, Ann. Bot. Soc. Zool.-Bot. Fenn. Vanamo 20(3): $27(1944)$

type: New Caledonia, Noumea, ad corticem arborum, F. R. M. Wilson, 1890 (H)

Examination of the type specimen has revealed that it belongs in the genus Leconactis.

"Bombyliospora" quadrilocularis (NYL.) MASSALONGO, Atti I. R. Istit. Veneto, ser. 3, 5: 262 (1860)

This species has been placed in the genus CaZop Zaca by ZAHLBRUCKNER (1931), and this position is confirmed by HAFELLNER \& POELT (1979).

"Bombyliospora" thoroldi DODGE, Ann. Missouri Bot. Gard. 40: 386 (1953) type: Nigeria, Oyo prov., Iseyin, on Theobroma, C. A. Thorold 108 (not seen)

Judging from the original description this species belongs in $B i$ imbia because of its spore dimensions.

\section{B. Species provisionally referred to Catinaria}

Catinaria isidiza (MAKHIJA \& NAGARKAR) COMB. NOV. basionym: MegaZospora isidiza MAKHIJA \& NAGARKAR, Curr. Sci. 50(18): 823 (1981) type: India, Maharashtra, Mahabaleshwar, in moist evergreen forest, A. V. Prabhu \& M. B. Nagarkar 74.1820 (AMH)

This species resembles Catinaria versicolor closely, but differs by the presence of short, spherical to clavate, c. 0.1-0.2 m long isidia and by its different excipulum structure: the medullary excipulum consists of irregularly orientated hyphae which form a nearly compact tissue; the ectal excipulum is c. $100 \mu \mathrm{m}$ thick and is composed of radially arranged hyphae with c. 9-14 $\times 3-5$ $\mu \mathrm{m}$ large lumina, imbedded in a coriaceous matrix without interhyphal cavities, the distance between the lumina of adjacent hyphae being $c .5 \mu \mathrm{m}$. Also the structure of subhymenium and hypothecium is more dense than in C. vereicolor, and the paraphyse tips do not extend above the hymenial gelatine.

Features by which $C$. isidiza resembles $C$. versicolor, are: epithecium with a diffuse bluegreen pigment; hymenium c. $115 \mathrm{\mu m}$ high, I + greenish blue; ascogenous hyphae growing upwards; spores bicellular, c. $40 \times 16 \mu \mathrm{m}$ in size, two or 
one together in each ascus; absence of any detectable lichen substance in the thallus.

Catinaria isidiza is known only from Western India (MAKHIJA \&AGARKAR 1981).

Catinaria microcarpa (ZAHLBR.) COMB. NOV.

basionym: Megalospora versicolor var. microcarpa A. ZAHLBRUCKNER apud SKOTTSBERG, Nat. Hist. Juan Fernandez and Easter Island 2(bot.): 364-365.

type: Juan Fernandez, Masatierra, quebrada Salsipuedes, auf Dayenia, C. \& J. Skottsberg, 20.1I.1916 (W)

The original description does not indicate discriminative characters by which this taxon differs from Catinaria versicolor. When comparing the descriptions, the following differences are found: apothecia small, 0.2-0.3 mm diam., soon convex with inconspicuous margin; spores small, 27-38 $\times 17-20 \mu \mathrm{m}$. Own observations on the original material have shown that the size of the apothecium is sometimes much larger, to $1.0 \mathrm{~mm}$ diam., but still smaller than usual in $C$. versicolor. The spore size appeared to be larger, c. $50 \times 20 \mu \mathrm{m}$, as measured from degenerating spores in the asci, and falls within the range of $C$. versicolor. This leaves as differentiating character only the fairly small, soon convex apothecia. However, as an additional difference the apothecia appeared to lack an arachnoid medullary excipulum. Thus a status as an independent species seems justified for $C$. microcarpa.

The poor condition of the apothecia in the type specimen did not permit more accurate observations of additional anatomical characters.

Two duplicates were available of the original material. Both could be taken from the same tree, but are not likely to be fragments of the same lichen thal1us. The specimen in $W$ is considered to be the type, because it is the most likely to be investigated by ZAHLBRUCKNER.

Catinaria versicolor (FEE) COMB. NOV.

basionym: Lecanora versicolor FEE, Essai Cryptog. Ecorc. officin., p. 115, Tab. XXVII, Fig. 4 (1824)

type: in America meridionali, ad Cinchonon, hb. Fée (G)

NOTE. The type material in the herbarium of Fée consists of a card with four lichen fragments, three of which belong to Megalospora sulphurata, and one to Catinaria versicolor. FEE's description (1824) mentions a yellowish-green thallus ("flavovirescente") and a darkbrown disc ("fusco"), which seems more attributable to Megalospora sulphurata than to Catinaria versicolor. However, the specimen of the latter species is in poor condition and shows unhealthy co- 
lours agreeing with the type description. In his Supplement (1837) FEE describes the spores as bilocular, straight and with two in an ascus, which is characteristic of Catinaria versicolor, thus the only specimen of this species on the card of Fee's herbarium is to be considered as the type.

synonyms:

Lecidea versicolor (FEE) FEE, Essai Cryptog. officin. Suppl., p. 104 (1837); Heterothecivm versicolor (FEE) FLOTOW, Bot. Zeitung (Berlin) 8: 555; - BombyZiospora versicolor (FEE) MASSALONGO, Ricerch. Auton. Lich., p. 115 (1852) (name, not interpret.); - Bacidia versicolor (FEE) TREVISAN, Spighe e Paglie, p. 7 (1853); - Biatora versicolor (FEE) MONTAGNE \& v. d. BOSCH apud JUNGHUHN, Plant. Jungh. fasc. IV: 460 (1855) (not seen); - Patellaria versicolor (FEE) MUELLER ARG., Flora 65: 330 (1882) (Lich. Beitr. 433); - Biatorina versicolor (FEE) HELLBOM, Bih. Kgl. Svensk. Akad. Handl. 21, afd. 3, 13: 109 (1896); Psorothecium versicolor (FEE) A. ZAHLBRUCKNER, Sitzingsber. K. Akad. Wiss. Wien, math.-naturw. Classe II (1): 396 (1902); - Megalospora versicolor (FEE) A. ZAHLBRUCKNER, in ENGLER \& PRANTL, Natür1. Pflanzenfam. 1(1): 134 (1907).

? Lecidea versicolor var, argyrodes VAINI0, Ann. Acad. Sc. Fenn. ser, A, 6(7): 124 (1914); - Megalospora versicolor var, argyrodes (VAIN.) A. ZAHLBR., Catal. Lich. Univ. 4: 92 (1927)

type: Santo Domingo, ad corticem arboris prope La Cumbra, C. Raunkiaer 483 (not seen).

NOTE. The original description suggests that this concerns a specimen of Catinaria versicolor with thick, pale apothecium margin.

Lecidea versicolor var. major VAINIO, Acta Soc. Fauna F1. Fenn. 7(2): 36 (1890); - Megalospora versicolor var. major (VAINIO) A. ZAHLBRUCKNER, Catal, Lich. Univ. 4: 92 (1927)

original material: Brasil, Minas Gerais, ad corticem arborum prope Sitio, 1000 m.s.m., Vainio, Lich. Bras. Exs. 720 (BM, K in BM, M), 831

NOTE. The description suggests that it concerns specimens of Catinaria versicolor with large, strongly pigmented apothecia. No lectotype has been selected because no specimens from TUR were at hand.

Megalospora versicolor var. testaceopallida MALME, Ark. Bot. 18(12): 8 (1923) type: Brasil, Minas Geraes, Sao Joao del Rey, Malme, Exp. I Regnel1. Lich. 291 (S)

NOTE. This concerns a specimen of Catinamia versicolor without dark pigment, thus with pinkish apothecia, like "Megalospora carmeorosula".

Leconora alboatrata NYLANDER, Acta Soc. Sci. Fenn. 7: 446 (1863)

original material: Colombia, Lindig 777 (H-Nyl. p.m. 3540), 2705 (not seen). NOTE. No lectotype has been chosen since only one of both Lindig collections was at hand. It shows that the present name concerns plants of Catinaria versicolor where the apothecia have a pale margin and a dark disc. As there occur intermediates in which the inner part of the margin is dark, there seems to be no reason to maintain this taxon. However, the distribution of such plants seems to be restricted to Colombia, Mexico and Venezuela.

Megalospora carneorosula BOULY de LESDAIN, Lichens de Mexique, p. 23 (1914) type: Mexico, Michoacan, Morelia, Cerro Azul, A. Brouard 4059 (ISO in US) NOTE. This concerns a variation of Catinaria versicolor with unpigmented, pinkish apothecia, like "legalospora" versicolor var. testaceopallida. The isotype specimen in US is probably the only specimen left after the herbarium of 
Bouly de Lesdain has been destroyed in the second worldwar.

Lecidea dichroma FEE, Bul1. Soc. Bot. France 20: 319 (1873); - Megalospora versicotor var. dichroma (FEE) RIDDLE, Bu11. Torrey Bot. C1ub 44: 327 (1917); Megalospora dichroma (FEE) A. ZAHLBRUCKNER, Catal. Lich. Univ. 4: 87 (1927) type: Brasil, prov. Rio de Janeiro, Glaziou 5520 (ISO in G, M) NOTE. The collections fall completely within the range of variation of Catinamia versicolor.

Lecidea glaucescens NYLANDER, Flora 38: 675 (1855); - Psorotheciton glaucescens (NYL.) MASSALONGO, Atti I. R. Istit. Veneto, ser. 3, 5: 261 (1860); Megalospora glaucescens (NYL,) A. ZAHLBR,, Catal. Lich, Univ, 4: 87 (1927)

original material: Peru, prope Sachapata, W. Lechler, P1. Peruv. ed. R. F. Hohenacker 2562a (SYN in G, H, L, M)

NOTE. The isotype specimens do not seem to be parts of a singe thallus, but they might be collected on a single tree. They show no significant features to separate them from Catinaria versicolor. No lectotype has been chosen among them because there might be additional material in PC which could have been studied by NYLANDER for his original description.

Lecidea incondita KREMPELHUBER, Flora 59: 316 (1876); - Patellaria incondita (KREMP.) MUELLER ARG., Flora 68: 505 (1885) (Lich. Beitr. 942); - Patellaria versicolor var. incondita (KREMP.) MUELLER ARG., Flora 69: 290 (1886) (Lich. Beitr. 1028); - Lecidea versicolor var. incondita (KREMP.) VAINIO, Acta Soc. Fauna F1. Fenn. 7(2): 36 (1890); - Biatorina versicolor var. incondita (KREMP.) HELLBOM, Bih. Kgl. Svensk. Vetensk.-Akad. Hand1. 21, afd. III, 13: 109 (1896); - Megalospora versicolor var, incondita (KREMP.) BOULY de LESDAIN, Lich. du Mexique, p. 23.

type: Brasil, Rio de Janeiro, Glaziou 5519 "a", 1878 (G)

NOTE. The only specimen mentioned in the original description is Glaziou 5519a. However, no such specimen has been found, only a single specimen of Glaziou 5519 (no -a) in $G$, which is in accordance with the original description. Apparently this collection is mixed up, for, as KREMPELHUBER indicates, the same nr, is also referred to in the original description of Lecanora camptotheca FEE (1875, p. 314), a species with linear spores having four or more locules and occuring with four to eight in each ascus. The confusion around this mixed collection probably brought ZAHLBRUCKNER (1927, p. 33 and 1928, p. 771) to mention Lecanora camptotheca on two places: as Catillaria camptotheca (syn. Lecidea incondita KREMPELH.), and as a synonym of Haematoma puniceum var. mfidulum. The latter interpretation seems to agree best with the type description and the former combination seems best to be regarded as erroneous.

The taxon falls completely within the range of variation of Catinamia versicolor.

Patellaria lividocincta MUELleR ARG., Flora 64: 227 (1881) (Lich. Beitr. 287); - Patelzaria versicolor var. Zividocincta (MUELL. ARG.) MUELLER ARG., Bu11. Soc. Bot. Belgique 32: 141 (1894); - Megalospora versicolor var. Zividocincta (MUELL. ARG.) RIDDLE, Bull Torrey Bot. Club 44: 328 (1917); - Megalospora lividocincta (MUELL. ARG.) A. ZAHLBRUCKNER. Catal Lich. Univ. 4: 87 (1927) original material: Brasil, Apiahy, Puiggari 381 (ISO in G, W), 1080 (W), $1083(G)$

NOTE. No lectotype has been chosen because probably not all original material was available. The present specimens suggest that this taxon applies to plants with well-pigmented apothecia belonging to Catinaria versicolor. 
Lecidea obturgescens KREMPELHUBER, Flora 59: 271 (1876)

original material: Brasil, Rio de Janeiro, Glaziou 5520 (ISo in G, M) NOTE. This species was apparently based on a duplicate of the type of Lecidea dichroma, and falls thus equally within the range of variation of Catinaria versicotor.

An extensive description of Catinaria versicolor is given because it has until now figured as one of the most well-known Megalospora species.

Thallus crustose, whitish to dark grey, rather thin, c. 100-600 $\mu$ m thick, sometimes evanescent and then more or less endophloeodal, with smooth or rugulose surface, at the margin often with a fimbriate zone or with a black prothallus, composed of three layers: a solid, c. $20 \mu \mathrm{m}$ thick cortical layer of thickwalled hyphae; below this an 50-90 $\mu \mathrm{m}$ thick algal layer with arachnoid hyphae composed of c. 10-15 × $3 \mu \mathrm{m}$ large cells with c. $1 \mu \mathrm{m}$ thick walls; and a medullary layer consisting of arachnoid hyphae only, present only when the thallus is sufficiently thick. Algae green, subsphaerical, 6-9 $\mu \mathrm{m}$ diam. Soredia and isidia absent. Chemistry: zeorin and atranorin, usually in small amounts or absent.

Apothecia sessile, with c. 2-10 $\mu \mathrm{m}$ thick attachment layer and anchorage bundles originating from the apothecium base and the attachment layer, when juvenile concave with a prominent margin, 0.5-1 mm diam. and 0.35-0.45 mm thick, later flat or at last somewhat convex, to 2.5 mn diam. but hardly increased in thickness. Apothecium colour very variable: disc black or brown to grey or yellowish, margin equally very variable, black or brown to grey or yellowish, when black sometimes with a white pruina, sometimes black only in a rim around the disc, concolorous with the disc or not. Disc and margin dull.

Epithecium with diffuse, dark blue-green to olive-green pigment which is most concentrated around the paraphyse tips, but sometimes scarce or lacking. Hymenium (100-)110-140(-160) $\mu \mathrm{m}$ high, colourless, clear, I + deep blue to greenish blue, with soft gelatine. Subhymenium c. 35 m thick, composed of thin-walled, more or less parallel hyphae which pass gradually into the paraphyses, and c. 3-4 $\mu \mathrm{m}$ wide ascogenous hyphae which grow more or less straight towards the epithecium. Hypothecium c. $30 \mu \mathrm{m}$ thick, composed of coiling hyphae, with c. $10 \mu \mathrm{m}$ wide holes and remains of old spores. Excipulum composed of 3-3.5 $\mu m$ thick, thick-walled hyphae with c. I $\mu \mathrm{m}$ wide lumina. Medullary excipulum consisting of loose hyphae and including small aggregates of crystals (Calcium Oxalate?). Ectal excipulum c. 50-80 $\mu \mathrm{m}$ thick, compact by its dense, congluti-

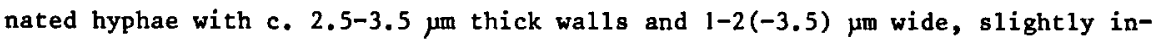
flated lumina and unthickened septa. Parathecium usually indistinct, restricted to the outer part of the apothecium. Subhypothecium not clearly separated from 
the hypothecium, c. 10-15 $\mu \mathrm{m}$ thick, in the centre up to $30 \mu \mathrm{m}$. Ectal excipulum usually with the same dark blue-green pigment as the epithecium in its outer part, sometimes limited to a zone around the disc. Apothecium base c. 250-400 $\mu \mathrm{m}$ wide. Apothecium chemistry: no acetone-soluble substances present in identifiable quantities.

Asci cylindrical, reaching to 7-12 $\mu$ melow the surface of the disc, c. $90 \times 20 \mu \mathrm{m}$. Ascus wall c. $3 \mu \mathrm{m}$ thick. Dome in young asci clear, c. $20 \mu \mathrm{m}$ thick, mostly without ocular chamber, in mature asci c. 8 m thick. I-reaction of free asci after potassium-hydroxide treatment: wall pale blue with a c. $0.5 \mu \mathrm{m}$ thick deep-blue outer layer, dome deep-blue. Opening of the asci irregularly roundish, fringed, apical. Paraphyses $1 \mu \mathrm{m}$ thick, clearly septate, with c. 15 um long cells, parallel, with c. I-2 anastomoses per paraphyse, in a c. $10 \mathrm{fm}$ thick zone in the top of the hymenium (epithecium) branched and gradually thickened to c. 3-4 $\mu$ width. Paraphyse tips extending above the hymenial gelatine. Ascospores bicellular, straight, (40-)50-60(-65) x 15-22 $\mu \mathrm{m}$, colourless, with two together or sometimes solitary in the ascus, with c. $2 \mu$ thick wall and less thick septa with a rather clear central pore, without epispore.

Pycnidia immersed in small warts with a dark tip, in cross section roundish and c. $0.3 \mathrm{~mm}$ diam. Conidiophores composed of single phialides measuring $c$. 7-10 $\times 2 \mu \mathrm{m}$, which are slightly and gradually narrowed towards the opening. Pycnospores weakly clavate, c. $3.5 \times 1 \mu \mathrm{m}$.

\section{Distribution and ecology}

Catinaria versicolor is largely limited to the neotropical mountains, where the species is rather common. This is demonstrated by the many specimens available from Mexico, Costa Rica, Venezuela, Colombia and Southern Brasil. From outside this range only a single collection was available, from Zaire, Africa (Lambinon 71-1206). Its altitudinal range 1 ies between c. 1500 and $3500 \mathrm{~m}$, but in Southern Brasil it may descend to $850 \mathrm{~m}$ (Sipman 12681). Its favorite habitat seems to be light, mossy forest, but it can tolerate a considerable shade. It is also able to maintain itself in secundary vegetation.

\section{Remarks}

For the differences with the genus Megalospora, see chapter 4. The distinction is very easy because Catinaria versicotor has its spores with two together in each ascus, and shows a clear hymenium without oil droplets and reacting $\mathrm{I}+$ greenish blue. The species has, like $C$. microcarpa and $C$. isidiza, been placed in the genus Catinaria because of its resemblance to $C$. grossa (cf. 
p. 61). However, it has been much confused with Megalospora sulphurata, already by its first author (cf. p. 172), and has been recorded incorrectly for many countries, e.g. New Zealand (cf. p. 123).

The present species is very variable in many respects: 1. the size of the apothecia varies from c. 1.3 to $2 \mathrm{~mm}$ for fully developed stages, and their thickness from $0.35-0.45 \mathrm{~mm}$; 2. pruina is rather frequent on young apothecia but usually absent from adult ones. It is most frequent, but not strictly limited, to dark apothecia; 3. the presence of pigment in the epithecium and ectal excipulum is very variable, both in intensity and in distribution. Sometimes it is limited to the excipulum, or to the epithecium ("Lecanora alboatrata"). Corresponding with a higher or lower concentration of pigment, the colours of the disc and the margin vary from black, grey-brown or beige to nearly white. Field observations suggest that the changes in pigment intensity are, at least in part, dependent on light exposure. The variation in pigment distribution is most likely genetically controlled. Perhaps more pigment types are involved, as indicated by the fact that the epithecium colour in microscopical sections varies from bluish or greenish black to dark olivaceous or brownish. However, degradation may also be involved, as is shown by the fact that unhealthy apothecia are brown.

Apart from these there is a number of further species attributable to Catinaria, which have been placed in Megalospora, mainly by ZAHLBRUCKNER (1927), but differ conspicuously by their small spores and, in as far as checked, also by absence of oil droplets in the hymenium and intense $I+$ blue-reaction of the hymenium. Following ZAHLBRUCKNER's own system they agree more with the genus Catillaria. However, since KILIAS (1981) revised the genus, it has a narrower circumscription which excludes the species in question. Because of their resemblance to Catinaria grossa they might be included in Catinamia. However, it is inevitable that a thus extended genus Catinamia will prove to be heterogenous, too. Therefore no detailed examinations and no new combinations have been made here. This concerns the following species:

Megalospora biclipea (SHIRLEY) A. ZAHLBRUCKNER, Catal. Lich. Univ. 4: 87 (1927) basionym: Patellaria biclipea SHIRLEY, Pap. Proc. Roy. Soc. Tasmania for 1893, p. 217 (1894). (no specimen investigated)

Megalospora bicolorata (VAIN.) A. ZAHLBRUCKNER, Catal. Lich. Univ. 4: 87 (1927) 
basionym: Catilzaria bicolorata VAINIO, Ann. Soc, zool.-bot. Fenn. Vanamo 1(3) 48 (1921)

(no specimen investigated)

Megalospora grossa (PERS. ex NYL.) VEZDA, Lichenes Sel. Exsicc. no. 1328: 1 (1975)

basionym: Lecidea grossa PERSOON ex NYLANDER, Acta Soc. Linn. Bordeaux 21: 385 (1857)

(= Catinamia grossa (PERS, ex NYL.) VAINIO. Investigated specimens: Vezda, Lich. Sel. Exs. 1328 (H), James 38/0052 (BM))

Megalospora kabayanensis (VAIN.) A. ZAHLBRUCKNER, Catal. Lich. Univ. $4: 87$ (1927)

basionym: Catizlaria kabayanensis VAINIO, Ann. Acad. Sci. Fenn., ser. A, 15(6) 108 (1921)

(no specimen investigated)

Megalospora maquilingensis (VAIN.) A. ZAHLBRUCKNER, Catal. Lich. Univ. 4: 88 (1927)

basionym: Catillaria maquilingensis VaINIO, Ann. Acad. Sci. Fenn., ser. A, 15 (6): 109 (1921)

(no specimen investigated)

Megalospora mesoleucodes (NYL.) DODGE, Trans. Amer. Microscop. Soc. 84: 506 (1965)

basionym: Lecidea melastegia fo. mesoleucodes NYLANDER, Lich. Fueg. et Patag., P. 15 (1888)

(no specimen investigated)

Megalospora meizoophthalma (VAIN.) A. ZAHLBRUCKNER, Catal. Lich. Univ, 4: 88 (1927)

basionym: Catizlaria meizoophthalma VAINIO, Ann. Acad. Sci. Fenn., ser. A, 15 (6) : $107(1921)$

(no specimen investigated)

Megalospora microphthalma (VAIN.) A. ZAHLBRUCKNER, Catal. Lich. Univ. 4: 89 (1927)

basionym: Catillaria microphthalma VAINIO, Ann. Acad. Sci. Fenn., ser. A, 15 
(6): $106(1921)$

(investigated specimen: Bur. Sci. 18170 (BM, isosyntype))

Megalospora ophthalmocarpa (VAIN.) A. ZAHLBRUCKNER, Catal, Lich. Univ. 4: 89 (1927)

basionym: Catillaria ophthalmocarpa vaINIo, Ann. Acad. Sci. Fenn., ser. A, 15 (6): 105 (1921)

(investigated specimen: Copeland 1348 (H) (type of Psorothecium ophthalmocarpum fo. caesiopruinosum RAES.))

Megalospora pauaiensis (VAIN.) A. ZAHLBRUCKNER, Catal. Lich. Univ. 4: 89 (1927) basionym: Catillaria paraiensis VAINIO, Ann Acad. Sci. Fenn., ser. A, 15 (6): 108 (1921)

(investigated specimen: Bur. Sci. 8548 (BM) (isosyntype))

Megalospora stellenboschiana (VAIN,) A. ZAHLBRUCKNER, Cata1. Lich. Univ, 8: 395 (1932)

basionym: Catillaria stellenboschiana VAINIO, Ann. Univ. Fenn. Aboensis, ser. A, 2(3): 19 (1926)

(no specimen investigated)

\section{Lecania sulphureofusca}

Lecania (Pachylecania) sulphureofusca (FEE) MUELLER ARG., Revue Mycol. 9: 133 (1887) (P1. 2 E)

basionym: Lecanora sulphureofusca FEE, Essai Cryptog. Ecorc. Exot. Offic., p. 116 (1824)

type: "In America ad corticem Cinchonae", herb. Fée (not seen, according to MUELLER ARG. 1887)

synonyms :

Patellaria sulphureofusca (FEE) MUELLER ARG., Flora 68: 505 (1885) (Lich. Beitr. 942).

Megalospora jamaicensis RIDDLE, Mycologia 4: 129 (1912)

Original material: Jamaica, on bark, Clara E. Cummings 138 and 142 (FH SYNTYPES)

? Leconora sulphureofusca var, albidofusca VAINIo, Ann. Acad. Sci. Fenn., ser. A, 6 (7): 27 (1914)

type: Dominica, ad corticem arboris minoris in Souffrière-Hil1, W. R. Elliott 1518 (not seen) NOTE. A difference in thallus colour, as given in the original description, is unlikely to characterise a useful taxon. 


\section{Description}

Thallus crustose, yellowish grey, rather thin, smooth or irregularly following the surface of the substrate, often cracked but not areolate, often with a black prothallus at the margin, with a c. $10 \mu \mathrm{m}$ thick cortical layer of megalospora-type (p. 20) and arachnoid layers inside with the algae concentrated in the upper c. $60 \mu \mathrm{m}$. Hyphae in the arachnoid part composed of c. 10-15 x $3 \mathrm{~mm}$ large cells, with c. 1 m thick walls. Algae green, subsphaerical, 6-9 $\mu \mathrm{m}$ diam. Isidia and soredia absent. Chemistry: usnic acid, zeorin and three unknown substances, one perhaps protocetraric acid.

Apothecia sessile, attached with their whole base, without clear attachment layer or anchorage bundles, c. 1 mm wide and 350 m thick, flat with a slightly or not-prominent, often crenulate margin, when young c. $0.6 \mathrm{~mm}$ diam. and flat, ultimately to c. $2 \mathrm{~mm}$ wide and somewhat convex with a more or less flexuose margin. Disc pale orange-brown to brown, dull. Margin yellowish, with a thalloid outer part which has the same colour as the thallus and is often crenulate.

Epithecium yellowish-brown to brown, usually with yellowish granules, 14-18 $\mu m$ thick. Hymenium 85-120 $\mu$ high, colourless, with oil droplets, I + deep blue. Subhymenium c. $35 \mu \mathrm{m}$ thick. Hypothecium strongly conical, in the centre to 70 $\mu m$ thick, of spongy structure. Excipulum composed of a persistent parathecium and a thalloid amphithecium. Parathecium c. $30 \mu \mathrm{m}$ thick, composed of compact, thick-walled, more or less radiating hyphae. Amphithecium arachnoid, with $c$. 4-7 $\mu$ mide algal cells and a c. 3-5 $\mu$ m thick cortical layer of megalosporatype. Subhypothecium not clearly differentiated, forming a compact zone below the hypothecium, in the top of the parathecial cone. Apothecium chemistry: no acetone-soluble substances demonstrated.

Asci cylindrical, c. $80 \times 30 \mu \mathrm{m}$, of lecanora-type, reaching to $20(-35) \mu \mathrm{m}$ below the surface of the disc. I-reaction of the free asci after potassium-hydroxide treatment: a thin outer part of the wall and the central part of the dome I + blue, the other parts pale blue. Paraphyses 1 m thick, septate, with c. $18 \mu \mathrm{m}$ long cells, parallel, with few anastomoses, in a c. $15 \mu \mathrm{m}$ thick zone below the surface of the disc (epithecium) more branched and thickened to $c$. $2 \mu \mathrm{m}$. Hymenial gelatine soft, extending above the paraphyse tips. Spores solitary, bicellular, colourless, straight, 70-90 x 20-25 $\mu \mathrm{m}$, with c. $2 \mu \mathrm{m}$ thick walls and c. $1.5 \mu \mathrm{m}$ thick septa, without clear pores or epispore.

Pycnidia subglobose, c. $0.1 \mathrm{~mm}$ wide, semi-immersed with brownish pore. Conidiophores of bayonet-type, c. $25 \mu$ long. Pycnospores bacillar, c. $5 \times 1 \mu m$. 
Distribution and ecology

The available specimens and literature records originate from Central America, the Antilles and Northern South America, and comprise the countries: Costa Rica, Colombia, Jamaica and Dominica. The Colombian and Costa Rican specimens are from well-illuminated thin treetrunks along pastureland, at an elevation of 1300 and $2600 \mathrm{~m}$.

Remarks

Lecania sulphureofusca resembles certain Megalospora species clearly by the large, solitary and bicellular spores, the presence of oil droplets in the hymenium, and the similar pycnidia and cortical layer of the thallus. Differences are the presence of a thalloid amphithecium without ectal excipulum, the low hymenium and the presence of additional substances in the thallus. Some

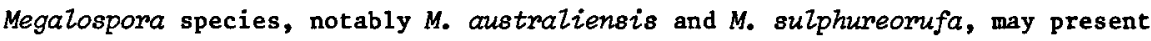
algae in the excipulum, but then the margin is not thalloid but retains the normal structure for Megalospora, that is with a clear ectal and medullary layer in the excipulum. Besides by these anetomical features Lecania sulphureofusca differs also by its apothecium ontogeny (cf. p. 60).

The present species is probably less rare than the few collections suggest. In the field it resembles a Lecanora species, notably from the varia-group, but may be recognised by the crenulate margin of the apothecia.

RIDDLE (1912) was the first to detect the species after its description by FEE and a Colombian record by NYLANDER (1863). At first he considered it to be a new species, M. jamaicensis, and later (1917) he erroneously united this with M. sulphureorufa, a New Caledonian species.

\section{Mycoblastus}

Here the species are mentioned which have been placed in Megalospora as delimited by MASSALONGO (1852). His delimitation was not acceptable because it excluded the type species, and the species have subsequently been transferred to Mycoblastus by e.g. ZAHLBRUCKNER (1927). No further investigations of these taxa have been made within the framework of this study. In the list below the correct citations are given in brackets, following ZAHLBRUCKNER (1927) and POELT (1969).

Megalospora affinis (Schaer.) Massal. (" Mycoblastus affinis (Schaer.) Schauer) Megalospora alpina (Fr.) Arn. (= Mycoblastus alpinus (Fr.) Kernst.) 
Megalospora dispora Knight (= Mycoblastus hypomelinus (Stirt.) Mül1. Arg.) Megalospora dulpicella (Nyl.) 01iv. (= Mycoblastus duplicellus (Ny1.) Zah1br.) Megalospora fucata (Stirt.) 01iv. (= Mycoblastus fucatus (Stirt.) A. Zah1br.) Megalospora melina (Krempelh.) 0liv. (= Mycoblastus melinus (Krempelh.) Hellb., considered to be a synonym of $M$. affinus (Schaer.) Schauer)

Megalospora sanguinaria (L.) Massal. (= Mycoblastus sanguinarius (L.) Norm.) MegaZospora sanguinaria var. microcarpa (Ny1.) 01iv. (= Mycoblastus sanguinarius fo. microcarpus (Nyl.) A. Zahlbr.)

Megalospora subsanguinaria (Stirt.) Wheld. \& Wils. (= Mycoblastus sanguinarius fo. subsanguinarius (Stirt.) A. Zahlbr.

\section{E. Various species formerly included in Megalospora}

Here the remaining taxa are reported which have formerly been included in Megalospora, but are not related to the Megalosporaceae or any of the groups treated before in this chapter.

Megalospora ikomae (RAES.) SATO, Index Plant. Nipponic., vol. 4, Lichenes, p. 116 (1943) (not seen)

basionym: Psorothecizon ikomae RAESAENEN, J. Jap. Bot. 16: 150 (1940)

type: Japan, prov. Inaba, ad corticem Pmani yedoensis, A. Yasuda 518 (not seen) NOTE. According to the original description this is probably a species of Mycoblastus.

Megalospora Lutea Flot., Linnaea 17: 21 (1843)

NOTE. According to ZAHLBRUCKNER (1927) this is a synonym of Lopadizm Zeucoxanthum (= Brigantiaea leucoxantha (Spreng.) R. Santesson \& Hafelln., cf. HAFELLNER \& BELLEMERE 1982c).

Megalospora premeella (MUELL. ARG.) A. ZAHLBRUCKNER, in ENGLER \& PRANTL, Natürl. Pflanzenfam. 1(1): 134 (1905)

basionym: Patellaria premneella MUELLER ARG., Lich. Epiphylli Novi, p. 5 (1890) type: Brasil, "foliicola prope Apiahy", Puiggari 2803 pr. p. (not seen) NOTE. Santesson (1952) places this species in the genus Psorotheciopsis. From his description it becomes clear that it is not closely related with Megalosporaceae. It seems advisable to keep it in Psorotheciopsis. 
Megalospora simplex VEZDA, Folia Geobot. Phytotax. 10: 428 (1975)

NOTE. Judging from the description this species differs from Megalospora by the absence of guttules in the hymenium and by the presence of single-celled spores. It is probably more related to Mycoblastus.

Megalospora tricolor (MONT.) v. OVEREEM-de HAAS, Bull. Jard. Bot. Buitenzorg, ser. 3-4, p. 120 (1922)

basionym: Biatora tricolor MONT., Ann. Sci. Nat., Bot., ser. 2, 18: 266 (1842) NOTE. According to ZAHLBRUCKNER (1927) this is a synonym of Lopadizon leucoxanthum (- Brigantiaea leucoxantha (SPRENG.) R. SANTESSON \& HAFELLN.)

F. Nomina dubia

Lecidea atrobmonnea ZENKER apud GOEBEL \& KUNZE, Pharmaceutische Waarenkunde 1 $138(1827-29)$

type: unknown.

NOTE. Among the Brasilian collections of Megalospora sulphurata one specimen was named Lecidea atrobmunnea. However, no certainty exists whether it really belongs to this species, because the original description is unclear and does not specify a type specimen and no material of this species, studied by ZENKER, could be traced.

Megalospora tasmanica (JATTA) A. ZAHLBRUCKNER, Catal. Lich. Univ. 4: 91 (1927) basionym: Patellaria tasmanica JATTA, Malpighia 19: 182 (1905)

type: Australia, "Tasmania meridion., New-Town Creek nr. Hobart, sulla scorza di una Pomaderris", W. A. Weymouth 667 (FI)

NOTE. According to the original description this species has small, bicellular spores. However, examination of one of the type fragments revealed acicular spores.

Megalospora taylori DODGE, Nova Hedwigia 19: 478 (1971)

type: Australia, Tasmania, hb. Taylor sheet 641 (not seen)

NOTE. The original description mentions the presence of a lower cortex. This must be based on inaccurate observation, because a lower cortex is an unlikely structure in crustose lichens. Unfortunately the type was not available for study. 


\section{chapter 9. NOTES ON ECOLOGY, BIOLOGY AND CONSERVATION}

\section{A. Habitat ecology}

An accurate description of the habitat requirements of the Megalosporaceae is difficult to produce, because the label information is generally very scanty. This is largely due, no doubt, by the fact that most species grow in areas where an adequate habitat description cannot be given by lack of knowledge of the vegetation types and of the accompanying cryptogamic epiphytes. For these reasons the outlines given below are general and mainly based on field observations of the author in South America (Brasil, Colombia and Venezuela), New Guinea and New Zealand.

Megalosporaceae grow almost exclusively on organic substrates: bark of trees and shrubs, dead or dying bryophytes and ferns. Very few specimens are from decayed wood or rock.

Conspicuous is their preference for humid situations. Favorite habitats are mossy forests. Substrate choice also seems to be influenced by this moisture requirement, as is evidenced by the usually high capacity for water retention of typical Megatosporaceae substrates such as weathered bark, dying moss cushions and decaying branches.

Light demands appear to be fairly high. In dense forest the species are largely restricted to the canopee layer. In more open vegetations, e.g. in light Nothofagus forest in New Zealand or in alpine scrub in Papua New Guinea, the Megalosporaceae may be found even on tree bases. In general they inhabit the portions of the trees between the exposed, drier parts where Parmeliaceae such as Menegazzia, Pannoparmelia and Hypotrachyna abound, and the shaded and humid parts with thick moss cushions and Sticta species. In these habitats Pertusaria and Psoroma species are frequent companions of Megalosporaceae.

Data on the phorophytes, as far as available, are reported under the individual species. In general gymnosperms, such as Podocarpus and Phylzocladus, appear to be favored.

Altitudinal preferences vary, of course, with latitude. In warm-temperate areas, such as New Zealand and Japan, Megalosporaceae occur from near sea level to c. 1200 m altitude. In southern Brasil coastal localities exist but usually the family occurs in low mountains from about 500 up to c. $2000 \mathrm{~m}$ altitude. In tropical regions, e.g. Venezuela, the Philippines or New Guinea, the family occurs generally above $1000 \mathrm{~m}$ altitude and is most frequent around $2500 \mathrm{~m}$, but occasional collections are from as low as $300 \mathrm{~m}$ (Philippines, Hale \& Banaag 
24913) and as high as 4400 m elevation (Papua New Guinea, Sipman 15933).

Apparently the habitat requirements are most often fulfilled in mountain areas, where even in fairly dry regions condensation zones may occur which produce sufficiently humid habitats. These condensation zones may be at fairly low elevations in maritime areas, e.g. on the Galapagos Islands around $400 \mathrm{~m}$ and on the West Indian island Saba at $600 \mathrm{~m}$. This probably explains the low elevations of some tropical Megalosporaceae records, e.g. Megalospora sulphurata at $300 \mathrm{~m}$ on Ascension (James s.n.). In some mangroves the ecological requirements are apparently also fulfilled, as is shown by the occurence of Megalospora pachycheila and $M$. tuberculosa on the atlantic cost near Sao Paulo, Brasil (Sipman 13949, 14159).

The absence of MegaZosporaceae from most tropical lowland vegetations such as rainforest and savanna, suggests that constantly high temperatures are avoided.

\section{B. Life strategy}

Little is known about life strategies in lichens, in contrast with e.g. bryophytes (During 1979). A few data are available on growth rate and age of some epilithic lichens (Hale 1974) but for corticolous lichens, such as the Megalosporaceae, such information is generally lacking. The changing properties of their living substrates suggest that corticolous species behave in a way which is different from the investigated epilithic species.

Two features in Megalosporaceae are suggestive of a special life strategy: the presence of large thalli and of large spores. The large thalli, often over $10 \mathrm{~cm}$ diam., may cover bryophytes and sometimes even long Frullania shoots. Apparently the large size of the thalli results from a high growth rate, which probably serves to compete succesfully with bryophytes and other lichens, even foliose species. Large size of spores seems, at first sight, a disadvantage because it hampers dispersal by air and makes the spores more attractive for predators. Thus there must be a strong advantage for compensation. This is probably the availability of much protoplasma in the spores, by which a rapid start of the thallus growth is possible. This might provide a competitive advantage similar to the rapid growth of the adult thalli. Both features thus seem to be favorable for establishment and maintenance in a situation with strong competition of bryophytes, where most other lichens are at disadvantage. A good establishing capacity might well be needed frequently in such an environment because exceptionally dry or wet seasons or changes in the canopee configurations will often influence the equilibrium between bryophytes and lichens in a way 
that lichens are killed or find short opportunities for (re-)establishment.

Among crustose lichens a high growth rate is also known from Pertusaria shenondoensis (HALE 1974, as $P$. shenondoahensis), a member of a genus which shares with Megalospora the usually large size of thallus and spores. BARKMAN (1958, p. 196, 199) records for Pertusaria species a capacity to overgrow mosses. Thus many Pertusaria species seem to have a comparable life strategy.

\section{Dispersal capacity}

Indications for the dispersal capacities of Megalosporaceae have been obtained from the present distribution patterns. Many species are restricted to mountain areas, and thus the distance and age of the mountain areas may give such indications. B.g. the occurence of Megalospora coccodes ssp. nigricans and M. pruinata ssp. Lamii on mountains of tertiary origin in the Malaysian area, situated at distances of c. 500-1000 km from eachother, suggests that such distances can be bridged by Megalosporaceae. Longer distances, e.g. to the New Guinean mountains, could have been bridged during cold periods in the earth history, when intermediate, lower mountains were inhabitable. In addition, the restriction of many taxa to New Zealand, Australia or New Caledonia shows that distances of c. $1500 \mathrm{~km}$ usually form an effective barrier. However, the occurence of Megalospora atrorubicans ssp. atrombicans and M. sulphurata on the remote and young mountainous islands of the Hawaiian Archipelago indicates that both species have been able to cross distances of over $2000 \mathrm{~km}$. These examples are exceptional among Megalosporaceae, and the crossing of the large distance might have been enabled by intermediate stations which have disappeared since.

At present it is unclear by what means the large spores of Megalosporaceae are dispersed. Wind dispersal seems lees probable because true wind-dispersal spores are smaller, measuring generally c. 10-20 $\mu \mathrm{m}$ diam. (van ZANTEN \& POCS 1981 , p. 505). Transport by sticking with the epispore to birds or insects could be imagined. No clear correlation between spore size and dispersal capacity has been found.

The apparent capacity to cross distances of $500-1000 \mathrm{~km}$ does not imply, of course, that the crossing of such distances is of frequent occurence. On the contrary, the large size of the spores suggests that the usual dispersal is over short distances only. Moreover the importance of short-distance dispersal for Megalosporaceae is demonstrated by the occurence of isidia or soredia in several species and in several areas. Isidia and soredia are supposed to be 
efficient short-distance dispersal units (cF. HENSSEN \& JAHNS 1973). Their significance in Megalosporaceae is demonstrated by the presence of isolated populations consisting exclusively of sorediate specimens, e.B. in Megalospora sulphurata on Ascension, Japan and New Caledonia, in M. tuberculosa in the northeastern United States and in $M$. compyZospora on Tasmania. These populations give the impression of being relics of former wider ranges, which are due to better survival possibilities of such sorediate populations. Similarly, relict populations depending for their survival on vegetative reproduction are postulated among hepatics by STEPHANI (cf. SCHUSTER 1969, p. 85).

\section{Conservation}

A need for conservation of Megalosporaceae is indicated not so much by their direct economical use, but by their scientific interest and their possible importance as indicators of ecological continuity. Such a use of lichens has been developed by ROSE (1976), who was able to recognise primary forest relics in Great Britain on the basis of local survival of virgin forest-inhabiting lichens. The disappearence of e.g. Megalospora tuberculosa in Europe suggests their potencies for such a use.

Many Megalosporaceae have a restricted distribution and deserve thus special care. The principal areas where these species occur, are: Madeira, Indonesia, Sabah, New Guinea, New Caledonia, Australia (Queensland, Lord Howe Island, New South Wales, Tasmania) and New Zealand. The species are generally found in humid forests and are common in suitable habitats, as far as known. In the temperate areas such forests used to be widespread (often locally known as "rainforest"), but are decreasing rapidly by logging. Notably in Tasmania, where e.g. Megalospora gompholoma ssp. fuscolineata has become rare, and New South Wales some species might come in danger of extinction. In warm regions the species are usually restricted to mountain forests above $2000 \mathrm{~m}$ elevation. Because such elevated land is limited in most countries, the mountain species tend to be rare and thus vulnerable to extinction. Fortunately their habitats have a certain degree of natural protection because they are usually less favorable for modern agriculture or forestry, or are intentional1y protected as drainage basins or because of the risc for landslides. Some of such areas have already a protected status as nature reserves, e.g. Mount Kinabalu, Mount Wi1helm, Lord Howe Island, but in other areas the relevant mountain zones are already extensively cultivated, e.g. on Java. The habitats of Megalospora on Madeira, Sao Thomé and the Mascarene Islands deserve attention for this reason, while logging and extensive cattle grazing could become a serious threat for 
species in New Caledonia and Queensland.

The widespread species Megalospora atrombicans, $M$. sulphwrata and $M$. tuberculosa, with seemingly good dispersal capacities, seem to be less vulnerable, though the possibility should not be ruled out that some are obligate virginforest inhabitants. Some species with a seemingly wide range are in fact only known from few localities. Notably Megalospora coccodes, whose range includes Africa and South America, has in fact been found only once in the Neotropics. Its range thus might be restricted to sma1l areas in Africa and America, and it might already have disappeared on the latter continent. For this reason the habitats of Megalospora coccodes and $M_{*}$ priinata in the mountains of eastern Tanzania, Ruanda, Burundi and Zaire deserve attention.

Relict populations merit a special attention. Several such populations are known from widespread species, which have developed special characters, e.g. structures for vegetative reproduction. The most obvious examples are the populations, characterised by the production of soredia, of Megalospora tuberculosa in the northeastern United States ("Bombyliospora porphyritis") and in Europe ("Bomby Ziospora pachycarpa"), of M. sulphurata in Japan ("Megalospora nipponensis") and of $M$. compyZospora on Tasmania. All of them concern restricted populations treatened with extinction. 


\section{chapter 10. DISTRIBUTION PATTERNS}

The family Megalosporaceae is best represented in Australia and New Zealand. As the map of the generic distributions (Fig. 13 on p. 81 ) shows, the genus Austroblastenia is restricted to that area, the genus Megaloblastenia has an additional, disjunct range in southern South America, and only the genus Megalospora is well represented outside this area and has a wide tropical distribution. Consideration of the numbers of species present in various countries (in Table 3) confirms the importance of Australia and New Zealand for the Megalosporaceae, but in addition New Guinea appears to be rich in species, all of which, however, belong to a single genus, Megalospora. Away from this

$\begin{array}{lrc}\text { NEW ZEALAND } & 10 & (6) \\ \text { NEW GUINEA } & 9 & (9) \\ \text { AUSTRALIA (exc1. TASMANIA) } & 7 & (5) \\ \text { INDONESIA } & 5 & (5) \\ \text { BRASIL } & 4 & (3) \\ \text { EAST AFRICA } & 4 & (4) \\ \text { MASCARENE ISLANDS } & 4 & (4) \\ \text { NEW CALEDONIA } & 4 & (4) \\ \text { SABAH } & 4 & (4) \\ \text { CENTRAL AMERICA + CARIBBEAN AREA } & 3 & (3) \\ \text { COLOMBIA } & 3 & (3) \\ \text { WEST AFRICA } & 3 & (3)\end{array}$

Table 3. List of the most important areas for the distribution of the Megalosporaceae, arranged to their number of species. The first number indicates the total number of Megalosporaceae present in each area, the number in brackets indicates the number of Megalospora species.

area the numbers of species decrease to three in e.g. Central America and West Africa, and less in northern temperate areas.

When comparing the distributions of the species of the genus Megalospora, the following distribution patterns become apparent:

1. Five species have a wide tropical distribution. of these $M$. tuberculosa is pantropical, but lacks on the Pacific Islands. Its range shows extensions into North America, Japan and Europe. M. sulphurata is also pantropical, is represented in the Pacific, but extends less far into temperate areas. $M$. atrombicans is absent from mainland Africa and America. M. coccodes and $M_{*}$ pruinata 


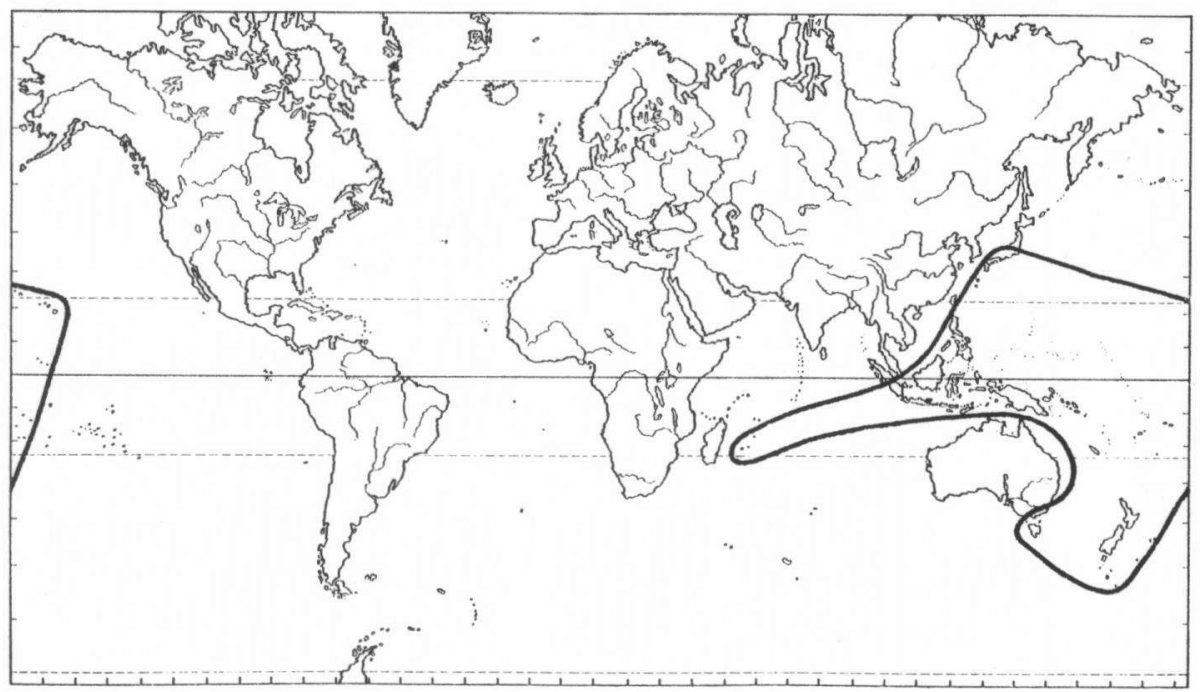

Figure 44. World distribution of the Megalospora species with atrorubicans-type spores.

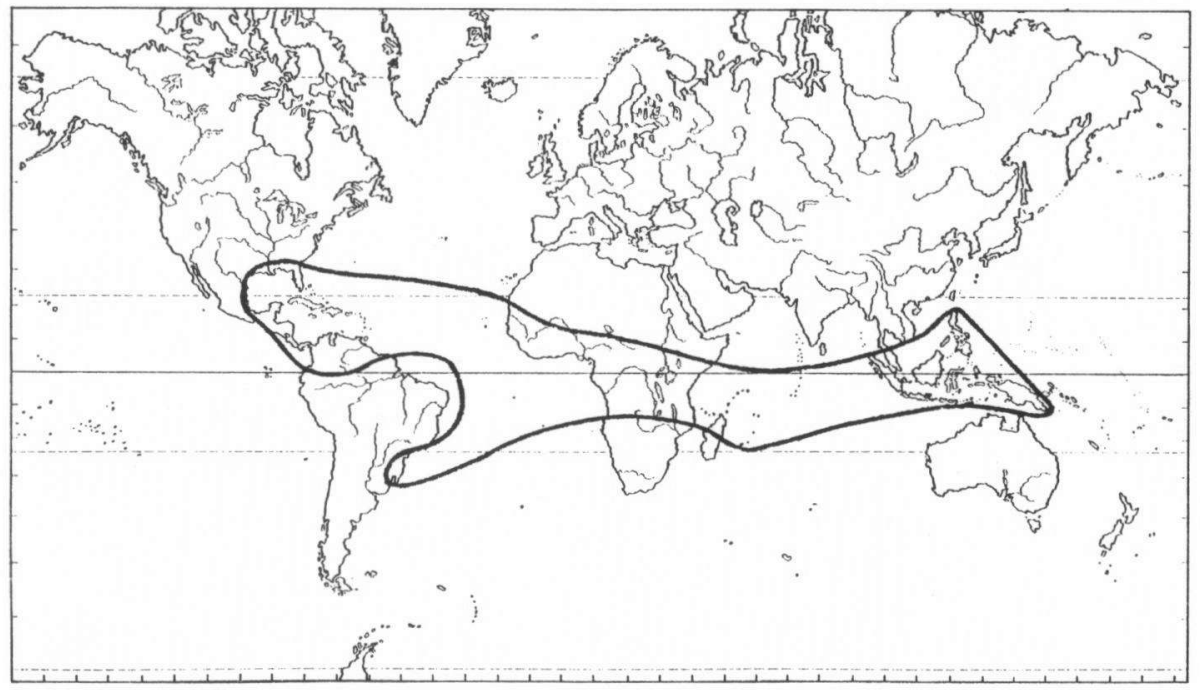

Figure 45. World distribution of the Megalospora species with coccodes-type spores. 


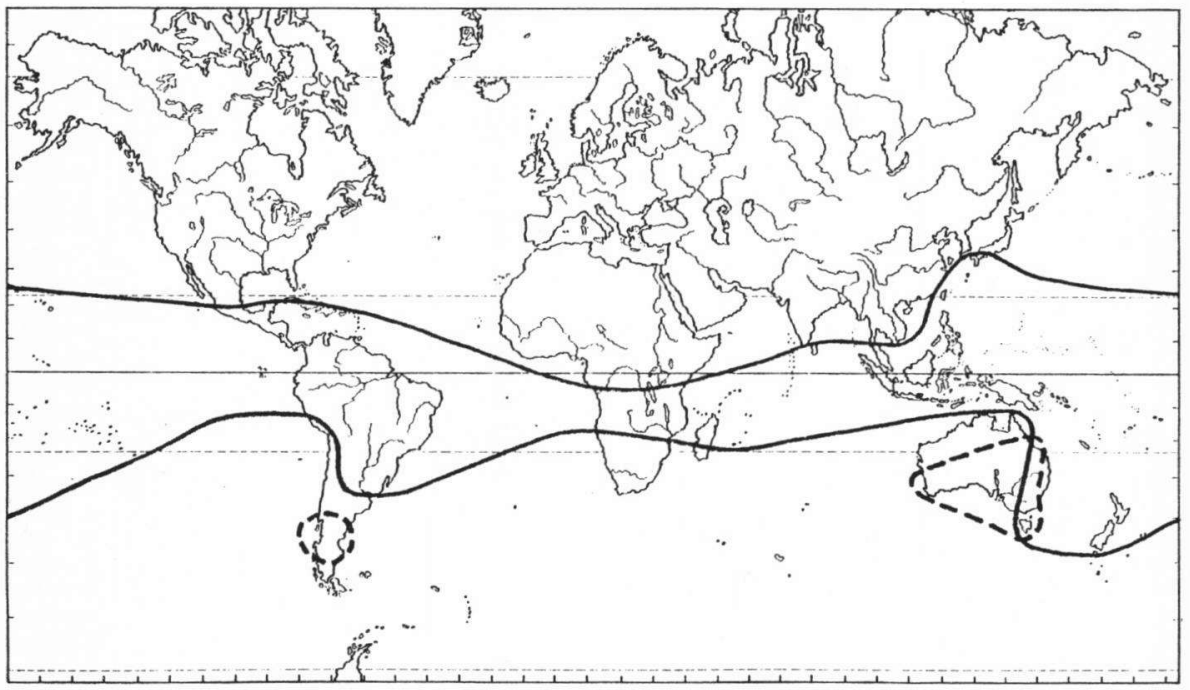

Figure 46. World distribution of the Megalospora species with lopadioidestype spores (broken line) and sulphurata-type spores (continuous line).

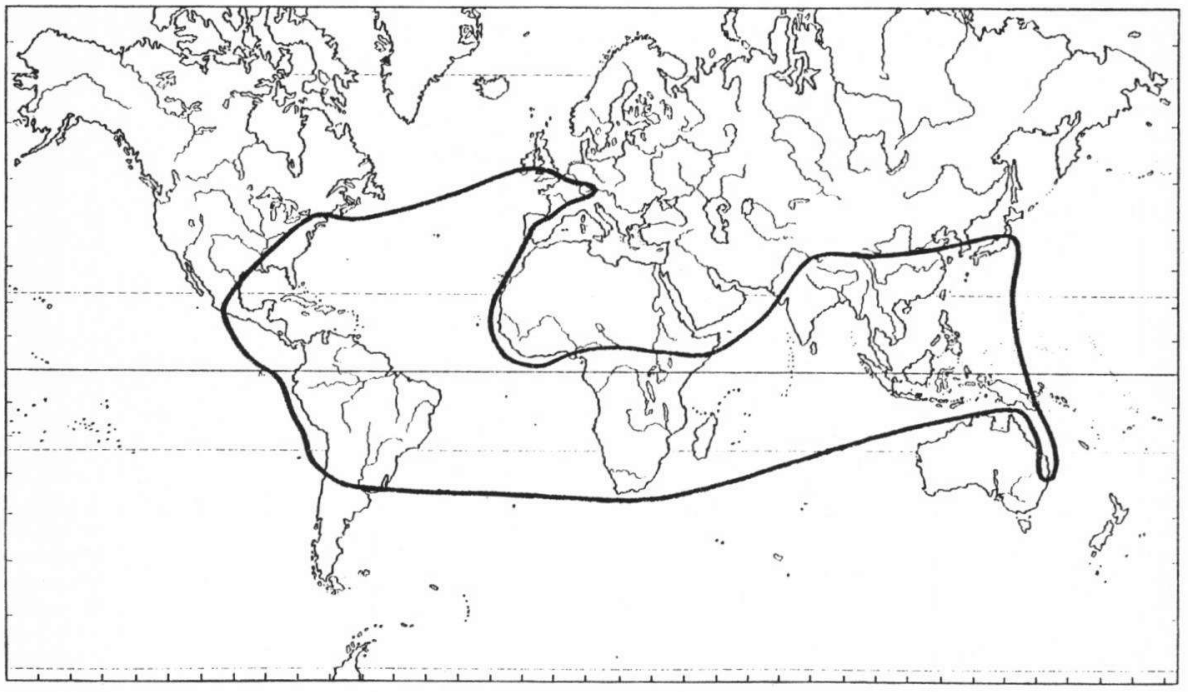

Figure 47. World distribution of the Megalospora species with tuberculosa-type spores. 
occur only in Africa and Asia, the first species, however, with a single record from America.

2. The remaining twenty species have very restricted distributions and are confined to a single country or a few adjacent countries. They occur mainly in New Zealand, Australia, New Caledonia and New Guinea, which area thus can be considered the distribution centre of the genus Megalospora. The distributions of most of these species can be summarised in the following seven groups: I. New Zealand. This concerns $M$. bartlettii, M. knightii and $M$. subtuberculosa. II. New Zealand, Tasmania and sometimes also the southern parts of mainland Australia. This concerns $M$. gompholoma and $M$. compylospora (the last occurs also on Lord Howe Island).

III. Tasmania and the southern parts of mainland Australia. This concerns M. Zopadioides and $M$. meZanodermia.

IV. Queensland and adjacent New South Wales. This concerns M. australiensis, $M$. inflexa and $M$. queenszandica.

v. New Caledonia. This concerns $M$. hillii and $M$. sulphureorufa (the last occurs also on Lord Howe Island).

VI. New Guinea. This concerns $M_{\text {. }}$ albescens, M. granulans and $M$. weberi. vII. New Guinea and the Malaysian area. This concerns $M_{\text {. halei. }}$

Four of these species do occur outside the distribution centre of Megalospora: $M$. kalbii from Argentina, $M$. maderensis from Madeira, $M$. pachycheila from the Neotropics and $M$. thomensis from western Africa.

The subspecies in Megalospora show similar distribution patterns:

1. M. atrorubicans ssp. atromibicans and $M$. coccodes ssp. coccodes have a wide tropical distribution.

2. M. atrombicans ssp. custralis and $M$. gompholoma ssp. gompholoma are restricted to New Zealand, the first with inclusion of Lord Howe Island. M. gompholoma ssp. fuscolineata occurs on Tasmania and the southern parts of mainland Australia. A Malaysian distribution is shown by $M$. coccodes ssp. nigricans and M. prininata ssp. Zamii, whereas $M$. pruinata ssp. fusca is known only from New Guinea.

Two subspecies occur only outside the main distribution centre of Megalospora: M. pruinata ssp. pruinata from mainland Africa and $M$. atrombicans ssp. sendaiensis from Japan and the Philippines.

When arranging the species of Megalospora according to their spore types (cf. Fig. 44-47) the following distribution patterns become apparent:

The group with coccodes-type spores occurs mainly in the Malaysian Archipe- 
1ago, New Guinea and Africa. Also most of the endemic species occuring outside the distribution centre of Megalospora have all coccodes-type spores: $M$. maderensis, M. pachycheila and $M$. thomensis.

The species with tuberculosa-type spores are concentrated in New Guinea and Australia (two species each). Only $M$. halei occurs also in the Malaysian area, and $M$. tuberculosa has a worldwide range.

The lopadioides-type spore is represented with two species in Australia (inclusive of Tasmania) and with a single species in South America (Argentina).

The group with sulphurata-type spores is concentrated in New Zealand, with three species on the North Island. Apart from these species the group comprises $M$. melonodermia, which occurs in Australia, and $M$. sutphurata, which has spread beyond the distribution centre and gained a worldwide range.

The species with atrorubicans-type spores are concentrated in New Zealand, New Caledonia and New Guinea, where three species each occur. The exceptions are $M$. gompholoma, of which ssp. fuscolineata occurs in Australia, and $M$. atrombicans, of which ssp. sendaiensis occurs in Japan and the Philippines, and ssp. atromibicans from the Mascarene Islands to the Hawaiian Islands.

Australia and New Guinea show the widest range of variation, because all spore types except one are represented there.

The distribution patterns of the genera Austroblastenia and Megaloblastenia are somewhat different. They occur only in the southernmost parts of the range of the family (cf. Fig. 13 on p. 81). The highest diversity for them is found in New Zealand, where all four species of the two genera occur. Tasmania and adjacent mainland Australia have one species of each genus, and in South America only a single Megaloblastenia species occurs.

Summarising the following general patterns can be found in the distributions of the Megalosporaceae, chiefly on account of the species with restricted distributions:

The area consisting of southern New Zealand and Tasmania offers the most diversified Megalosporaceae-flora. All three genera are represented, often by species which occur on both New Zealand and Tasmania, e.g. Austroblastenia pauciseptata, Megaloblastenia marginiflexa and Megalospora gompholoma. Among the Megalospora-species three spore types are represented: atrorubicans-type, lopadioides-type and sulphurata-type. The flora shows the strongest affinities with that of the southern parts of mainland Australia (Victoria) and of southern 
South America.

The area of New South Wales and Queensland (Australia) has a flora consisting only of a single genus, Megalospora, which, however, is represented nearly exclusively by endemic species. Basing on the represented spore types, the area shows its strongest affinities with New Guinea for its species with tuberculosatype spores.

The northern part of New Zealand is remarkable because of its endemic MegaZospora-species with sulphurata-type spores. The only area comparable in this respect is New South Wales/Queensland with a single such endemic. This area, however, differs considerable by the absence of endemic species with atrorubicans-type spores.

New Caledonia has a remarkable Megalospora-flora dominated by species with atrorubicans-type spores (4 species). In this respect it differs strongly from nearby Queensland, where such species are completely absent, but shows affinities with New Zealand and New Guinea, with three such species each.

The Megalospora-flora of Lord Howe Island, though peculiar, shows most affinities with northern New Zealand and is very different from that of mainland Australia.

New Guinea has an intermediate position, because its Megalospora-flora is composed of good representations of species with coccodes-type spores, characteristic of the tropical areas, of species with tuberculosa-type spores, by which an affinity exists with Queensland, and of species with atrorubicans-type spores, which indicates affinities with New Caledonia.

The tropical areas throughout the world are characterised by their range of species with coccodes-type spores. The widest range of variation occurs in Africa, with two endemic species and one endemic subspecies. Both the American and the Asian tropics, however, have their own endemism but there is a stronger similarity between the flora of e.g. Colombia and Indonesia, then between e.g. New Guinea and New Caledonia (cf. Table 4).

Distribution patterns comparable to those of the Megalosporaceae are known from hepatics, for which group SCHUSTER (1969) mentions genera which are limited to New Zealand, to New Zealand with Tasmania and the southern part of mainland Australia, or to New Caledonia. He relates these distribution patterns to an origin of these genera on the Gondwanic shield (cf. p. 205).

Apart from these distribution patterns for the taxa of Megalosporaceae, also the distribution of some characters uncorrelated with the taxonomic arrangement 
deserves attention. For instance, the occurence of pannarin, widely distributed in the family, is dominant in temperate areas, whereas in tropical areas usnic acid appears to be the dominant substance. Thus in the groups of Megalospora species with atrorubicans-type spores or sulphurata-type spores pannarin is only found in the representatives in New Zealand and southern Australia. And notably in Megalospora tuberculosa specimens with pannarin occur both in the norhern and southern temperate parts of its range. e.g. in North America, East Asia and southern Brasil. Also the presence of small, \pm concave and pruinose apothecia coincides rather well with occurence outside the tropical areas: such apothecia occur in $M$. atrombicans ssp. sendaiensis from Japan, in the East Asian and North American populations of $M$. tubercutosa and in $M$. kalbii from Argentina.

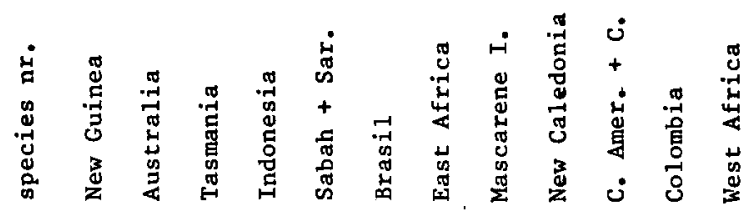

\begin{tabular}{|c|c|c|c|c|c|c|c|c|c|c|c|c|}
\hline New Zealand & 10 & 1 & 1 & 4 & 1 & - & 1 & - & - & - & - & - \\
\hline New Guinea & 9 & & 1 & - & 5 & 5 & 2 & 4 & 4 & 2 & 2 & 3 \\
\hline Australia (excl. Tasm.) & 7 & & & 3 & 1 & 1 & 1 & 1 & 1 & 1 & 1 & 1 \\
\hline Tasmania & 5 & & & & - & - & 1 & - & - & - & - & - \\
\hline Indonesia & 5 & & & & & 4 & 2 & 4 & 4 & 2 & 2 & 3 \\
\hline Sabah + Sarawak & 5 & & & & & & 2 & 4 & 4 & 1 & 2 & 3 \\
\hline Brasil & 4 & & & & & & & 2 & 2 & 1 & 3 & 2 \\
\hline East Africa & 4 & & & & & & & & 3 & 1 & 2 & 3 \\
\hline Mascarene Islands & 4 & & & & & & & & & 1 & 2 & 3 \\
\hline New Caledonia & 4 & & & & & & & & & & 1 & 1 \\
\hline Centr, America + Carib. & 3 & & & & & & & & & & & 2 \\
\hline Colombia & 3 & & & & & & & & & & & \\
\hline West Africa & 3 & & & & & & & & & & & \\
\hline
\end{tabular}

Table 4. Matrix of numbers of Megalosporaceae-species in common between the the most important areas for the distribution of the family. The column in in front gives the total number of species for each area. Note the similarity between the Megalosporaceae-flora of e.g. New Guinea, Indonesia, Sabah + Sarawak, East Africa, the Mascarene Islands and Colombia. New Zealand and Australia differ strongly from all other areas except Tasmania. 


\section{chapter 11. RECONSTRUCTION OF THE EVOLUTIONARY HISTORY}

\section{A. Estimation of the phylogenetic relationships}

A reconstruction of the phylogeny of the Megalosporaceae is hampered by the fact that the number of available characters is limited and their states seem at first sight to be distributed randomly throughout the family. Thus an arrangement into groups of closely related species could not be made simply by composing groups of species with few differences.

The difficulties are illustrated by a comparison of Megalospora atrombicans, M. gompholoma, M. oulphurata and $M$. campylospora. In this case there seem to be two possibilities for an arrangement according to phylogenetical relationship. The spore type in these four species suggests that the first two are closely related, as are also the last two. However, when considering the presence of usnic acid or pannarin and of a warted epispore, Megalospora atro-

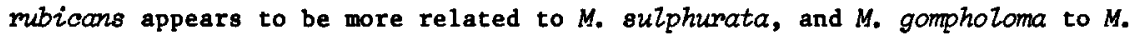
campylospora. Thus either the spore type has developed in more than one evolutionary line, or the presence of usnic acid or pannarin and of a warted epispore have done so (assuming that there has been no hybridisation). The first possibility seems to be the more likely one, because it requires change of only one character (more parsimonious).

However upon examination of species with other spore types it appears that most of the spore types may be accompanied by pannarin or usnic acid. Even within a single species both possibilities may exist, e.g. in Megalospora tuberculosa. In view of the many differences involved in the spore types (cf. p. 45), the assumption that all these spore types have developed independently in a phylogenetical line with usnic acid and in another line with pannarin seems less likely than the assumption that both chemical variants have developed independently in all evolutionary lines leading to the various spore types. Thus it seems better to base the principal evolutionary lines on spore characters rather than on the thallus chemistry.

The same reasoning can be applied to establish the significance of the spore type in comparison with e.g. excipulum chemistry, epithecium pigmentation and dimensions of apothecium, hymenium and spores. This leads to two conclusions: 1. For a phylogenetical reconstruction the spore type gives the most reliable indications.

2. Many variations in tha1lus chemistry, apothecium pigments and -substances, 
and dimensions of apothecium, hymenium or spores seem to have developed independently in several evolutionary lines.

Therefore the reconstruction of the evolution of the Megalosporaceae has been started with a hypothesis for the evolution of the spore types. Fig. 48 gives a possibility for such a hypothesis, which is based on the assumption that primitive ascospores are likely to be small; composed of a single or few cells, and thin-walled. Without change of this assumption Fig. 48 allows a few changes which do not increase the number of transformation steps required, and are thus equally plausible according to the parsimony principle, e.g. 1. sulphurata- and atrorubicans-type spores might have developed as ends of a single side-branch; 2. coccodes-type spores might be ancestral to tuberculosa- and lopadioides-type spores, after which the reduction of spore number developed independently from the line to the atrorubicans-type.

In order to test whether the hypothesis about the evolution of the spores, presented in Fig. 48, reflects the phylogeny in Megalosporaceae, an estimate of the phylogeny has been made by character compatibility analysis according to Estabrook (ESTABROOK \& ANDERSON 1978, MEACHAM 1980, 1981).

For this analysis the largest possible selection of the available characters for which a hypothesis on the evolution of its states could be made, and of which the states are likely to be uniquely derived, has been used. For the second reason e.g. dimensions, and granular substances or pigments of unknown constitution have been omitted. By this procedure little else but spore characters are left (characters $A-G$, see below). Therefore characters H-L have been added, basing on assumptions as indicated below. They appeared not to influence the results.

Following the requirements of the analysis any character with more than two states has been split into two-state entities, e.g. E and I, while derived states occuring in a single species have been omitted because they have no meaning for the recognition of relationships.

For the hypotheses on the evolution of the character states "outgroup comparison" has been used when possible, following WATROUS \& WHEELER (1981), who emphasize the value of this method. As outgroup the suborder Buelliineae (POELT 1974) has been choosen, because it is most likely to contain the closest relatives of the Megalosporaceae (cf. p. 70). Choice of the Lecideaceae as outgroup would not have changed the hypothesis for the important characters.

The following characters have been used for the compatibility analysis: 
evolution

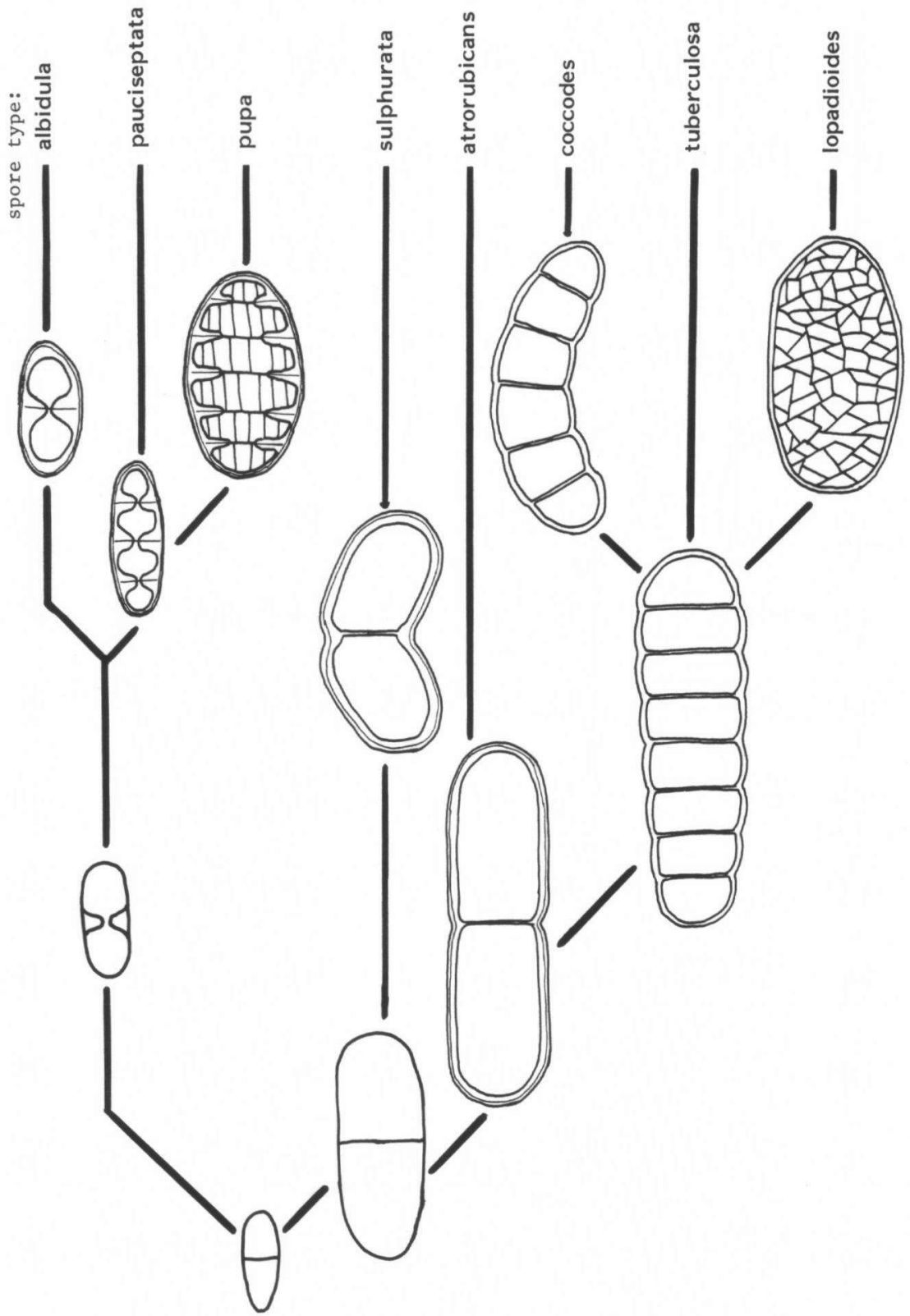

Figure 48. Preliminary hypothesis for the evolution of the spore-types in the Megalosporaceae. 
A. Occurence of oil droplets in the hymenium. Presence has been treated as the derived state, because comparable oil droplets do not occur in Buelliineae or Lecideaceae.

B. Number of spores per ascus. Two states have been distinguished: solitary, and two or more per ascus. Solitary spores are considered derived because they are uncommon in Buelliineae.

C. Number of cells per spore. Two states have been distinguished: bicellular and pluricellular. Bicellular is considered primitive because it is the dominant state in Buelliineae.

D. Thickness of epispore. Two states occur: c. $1 \mu \mathrm{m} \mathrm{thick,} \mathrm{and} \mathrm{c.} 0.5 \mu \mathrm{m}$ thick. A thin layer is considered primitive because a thick epispore seems to be absent in Buelliineae.

E. Occurence of thickenings on the spore septa. Four states occur: completely thin; completely thick except for a central pore; thin with a thick ring along the attachment line of the septum, which shows as a knob-like structure on the outer side (P1. 19); idem, but not showing as a knob-like structure. The last state occurs only in Megalospora maderensis and has therefore been omitted from the analysis. The other thick states have been treated as separate entities, $E_{1}$, with completely thick septa, and $E_{2}$, with a thick ring. In $E_{1}$ thin septa are considered to be the derived state because the character then becomes compatible with $A$ and C, cf. p. 200; in E, a thick ring is considered derived because it is not known outside Megalospora.

F. Occurence of longitudinal septa. The presence of such septa has been treated as derived because the bicellular spore is the common type in Buelliineae. G. Occurence of polar thickenings in the spores. The presence has been treated as derived because no such colourless thickenings are known in Buelliineae or other Lecanorales.

H. Occurence of tubercles on the thallus. This character is not constantly present in the species where it occurs, but it has been included for the analysis because the species concerned apparently have the potentiality to produce such tubercles. Probably this potentiality is not always actualised because of unfavourable growth conditions. Fot the analysis the occurence of tubercles has been considered constant for all species where they have been observed in any specimen. As derived state the presence of tubercles has been choosen because no such tubercles are known in Buelliineae or any other lichen group outside the Megalosporaceae.

I. Thallus chemistry. The presence of lichexanthone, pannarin and usnic acid 
have been used as different states. The occurence of lichexanthone has been omitted from the analysis because it occurs only in a single species, Megalospora pachycheiza. There was no reason to suppose that lichexanthone is a derived state of either usnic acid or pannarin, thus $M$. pachycheila has been treated as having the underived state of character I. Among the other two states no derived one could be selected. Therefore they have both been treated as derived states of separate entities, $I$, for the presence of usnic acid, and $I_{n}$ for the presence of pannarin. Megalospora tuberoulosa, where both substances may occur, thus functions in both entities. During the analysis it appeared that none of both entities takes part in the compatible cliques, see below.

$J$. Occurence of an extended attachment layer containing algae. For this character the same reasoning had to be applied as for $H$. The presence of such a layer has been considered derived because it is not known outside Megalosporaceae.

R. Occurence of obconical apothecia. Such apothecia are constant in Megalospora hillii and $M$. weberi, and inconstantly present in $M$. halei. For the analysis they have been treated as constant for the latter species. The conical shape has been considered derived, because it is rare in Megalos poraceae.

L. Occurence of algae in the medullary excipulum. These are constantly present in Megalospora austratiensis, but inconstantly in $M$. sulphureorufa. For the analysis they have been treated as constantly present in both species, and their presence has been considered to be the derived state, because of its rarity in Megalosporaceae

The resulting compatibility figures have been brought together in a compatibility matrix (Table 5). Manual searching for the largest cliques of mutually compatible characters has led to the discovery of four cliques of six characters and two of five. They all have characters $A$ and $G$ in comon, which therefore have been assumed to be true characters for the Megalosporaceae. Both characters indicate the separation of the same group, composed of Megaloblastenia marginiflexa and $M$. flavidoatra, which makes this separation probable. It concerns the entire group of species with albidula-type spores, which thus appear to mark a distinct evolutionary line. Because the group includes all species with the primitive state of character $A$, it is most likely to form an evolutionary line independent of the other Megalosporaceae.

Searching for the largest cliques in the compatibility matrix of the remaining taxa after removal of characters $A$ and $G$, has led to two cliques of five characters and two of four, all of which had characters $E_{2}$ and $K$ in common. However, these characters distinguish different groups not supported by other 
characters, and thus naturalness of these groups has only limited probability. A more probable division has been found on the following reasons. The thick state of character $E_{1}$ occurs both in the species with albidula-type spores and in some of the remaining species. Thus character $E_{1}$ is incompatible with characters $A$ and $G$, which have been found above to be very probably true characters, unless thick septa are considered to be the primitive state, and thin septa the derived state. In other words, the assumption that thick septa are derived is less probable because that would require an independent development of such septa in both the phylogenetical line with albidula-type spores and in the group of the remaining species. The assumption that the thick septa are the primitive state has as a consequence that the pauciseptata- and pupa-type spores

\begin{tabular}{|c|c|c|c|c|c|c|c|c|c|c|c|c|c|c|}
\hline & A & B & C & $D$ & $E_{1}$ & $\mathrm{E}_{2}$ & $\mathbf{F}$ & G & $\mathrm{H}$ & $I_{1}$ & $I_{2}$ & $\mathrm{~J}$ & $\mathbf{K}$ & L \\
\hline $\bar{A}$ & + & + & + & - & + & + & + & + & 7 & - & - & + & 7 & + \\
\hline B & & + & - & - & + & + & - & + & - & - & - & - & 1 & + \\
\hline $\mathrm{C}$ & & & + & - & - & + & + & + & + & - & - & + & 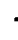 & - \\
\hline D & & & & + & - & + & - & - & + & - & - & - & 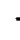 & - \\
\hline $\mathrm{E}_{1}$ & & & & & + & + & - & + & + & - & - & + & . & + \\
\hline $\mathrm{E}_{2}$ & & & & & & + & + & + & 1 & - & - & + & . & + \\
\hline $\mathbf{F}$ & & & & & & & + & + & + & - & - & + & . & + \\
\hline G & & & & & & & & + & + & - & - & + & . & + \\
\hline H & & & & & & & & & + & - & - & 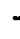 & . & + \\
\hline $\mathrm{I}_{1}$ & & & & & & & & & & + & + & 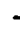 & 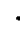 & - \\
\hline $\mathrm{I}_{2}$ & & & & & & & & & & & + & 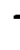 & & - \\
\hline $\mathbf{J}$ & & & & & & & & & & & & + & & - \\
\hline $\mathbf{K}$ & & & & & & & & & & & & & & + \\
\hline $\mathbf{L}$ & & & & & & & & & & & & & & + \\
\hline
\end{tabular}

Table 5. Character compatibility matrix for 33 taxa of Megalosporaceae.

mark one or two evolutionary lines that have developed independently from the lines of the remaining spore types because the latter share the derived state of character $\mathrm{E}_{1}$. Thus Austroblastenia pauciseptata and A. pupa are likely to form a next phylogenetically independent group, but it remains unclear whether they have developed as two separate lines or whether they are branches of a single line. The latter possibility seems likely because their spore types can 
be derived easily from eachother by assuming increased septation.

Upon separation of these taxa a character compatibility matrix of the remaining taxa has been made without character $\mathrm{E}_{1}$. Now two cliques with five characters and three with four characters are the largest that have been found. All have characters $E_{2}$ and $F$ in common. Character $E_{2}$ had already been found in the former step and therefore probably is a true character for the group. Thus all species with the derived state of character $\mathrm{E}_{2}$, viz. sulphurata-type spores, are likely to have evolved as a single phylogenetical line. However, as the remaining species have the primitive state of character $E_{2}$ in common, no indication is available whether the line of sulphurate-type spores appeared before or after the lines of the other spore types.

After removal of character $E_{2}$ from the matrix, character $F$ appears to be constantly present in the largest cliques: two of three characters and two of four. Because $F$ did appear already as a probably true character in the former step, the hypothesis seems acceptable that it, too, marks an evolutionary line, characterised by lopadioides-type spores.

After this step a continuation of the character compatibility analysis is not likely to recognise other spore types as indicators of evolutionary lines because the characters $B$ and $C$ are mutually incompatible. But in view of the acceptance of three spore types as such markers, it seems likely that they are nevertheless indicators of phylogenetical relationships. The incompatibility of character $B$ and $C$ means that the development of the bacillar spore type and/or the change in number of spores per ascus have occurred in more than one phylogenetical line. As none of both characters is supported clearly by the occurrence of other characters, no clear indication exists which of characters $B$ and $C$ has developed its derived state first.

In fact compatibility analysis of the remaining taxa reveals only characters with infrequent derived states as mutually compatible. As such characters do not serve to arrange the majority of the taxa, no phylogenetical reconstruction has been based on them and the scheme of the principal evolutionary lines (Fig. 49) has been completed by the assumption that all spore types mark separate evolutionary lines.

Geographical distribution patterns may also contribute to a hypothesis of phylogentical relationships. As pointed out in chapter 10, the spore types in the Megalosporaceae show clear differences in geographical distribution. Notably the distribution of the tuberculosa-type, which occurs on the Australian main- 
land but is absent from New Zealand, Lord Howe Island and New Caledonia, differs much from the atrorubicans- and sulphurata-type, for which the situation is the reverse (with a single exception for each spore type). This difference suggests that these distribution patterns reflect two different evolutionary lines. Similarly the special distribution pattern of the coccodes-type spores suggests a separate evolutionary line.

However, for the coccodes-type spores the following indications exist that they may represent more than one evolutionary line: Megalospora thomensis resembles $M$. tuberculosa very closely, especially the populations which occur in the same region. This resemblance is greater than with other coccodes-type species in Africa like $M$, coccodes or $M$. pruinata, cf. p. 148. Similarly $M$. maderensis differs considerably from the other species with coccodes-type spores and shows a certain resemblance to M: sulphurata, cf. p. 139.

Attempts to arrange the taxa within the spore type groups by character compatibility analysis failed by lack of groups of compatible characters. Every single potentially true character was unsupported by other characters and thus any hypothesis for a phylogenetical arrangement has a low probability. Therefore it did not seem worth while to present such an arrangement.

A schematical arrangement of the results of these procedures towards a hypothesis for the evolution of the Megalosporaceae is given in Fig. 49.

Basing on these results the species with albidula-type spores and those with pauciseptata- and pupa-type spores have been treated as separate genera, viz. Megaloblastenia and Austroblastenia, and the remaining spore types have been united in a single genus, Megalospora. Because of the weak indications that these spore types mark independent evolutionary lines, the species with tuberculosa- and coccodes-type spores, which used to be treated as a separate genus, Bombyliospora, have been united here with the species with bicellular spores.

The independent appearence of character states in several phylogenetical lines, as indicated on p. 196, suggests that their genetical background is present nearly completely in all species and that only minor changes are required for them to materialise. This would notably hold for most of the chemical variation. An alternative explanation of this phenomenon by assuming hybridisation seems not more likely because frequent hybridisations would be necessary, whereas no proof of the occurence of hybridisation in lichens has ever been given. Moreover the first explanation is supported by the observation of DIBBEN (1980, p. 32), who found that some of the chemical variants in Pertusaria occur in unrelated groups. 


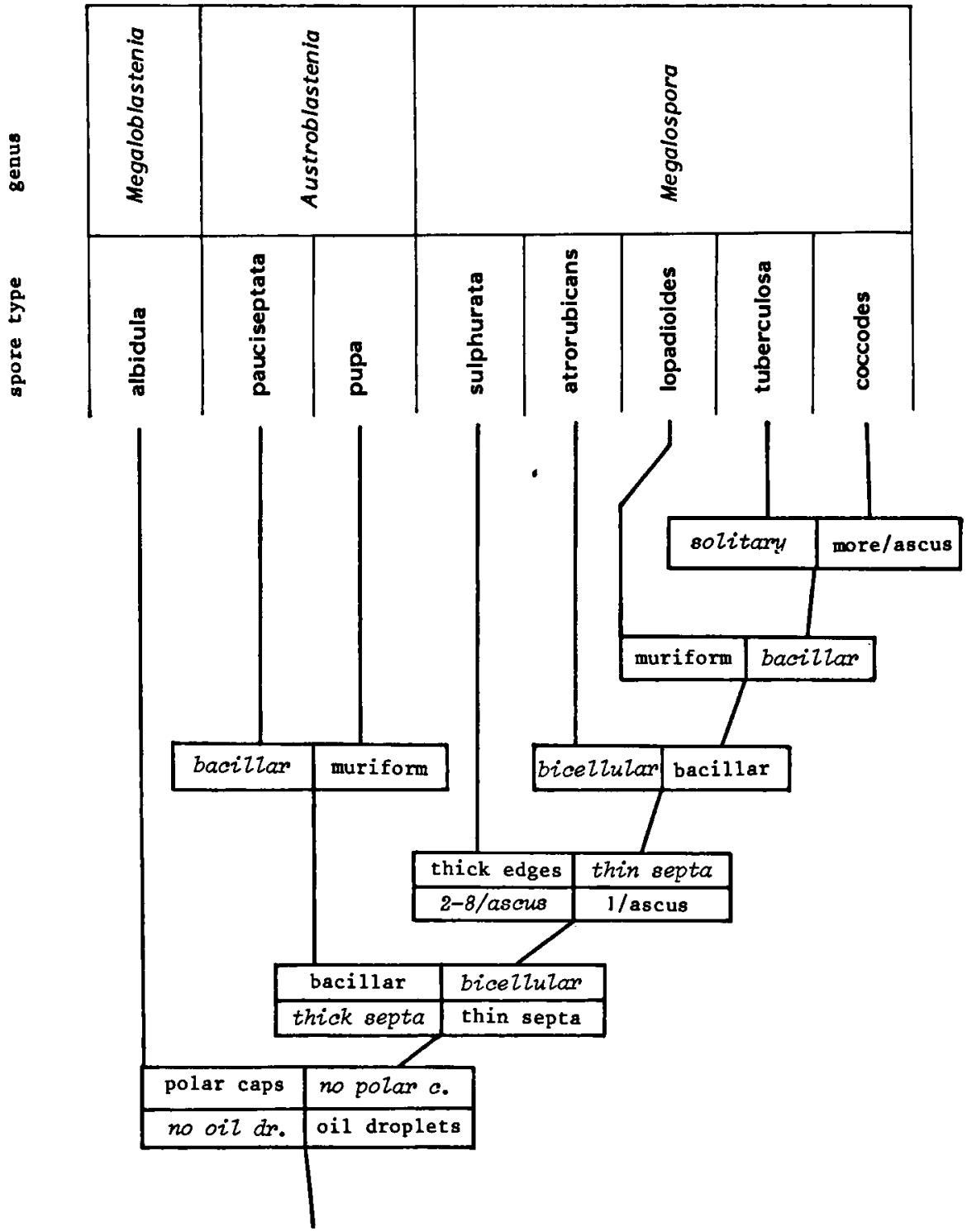

Figure 49. Cladogram of the principal groups of species in the Megalosporaceae. characterised by spores. In italics are primitive character states, in plain type derived states. 


\section{B. Chronological and geographical aspects}

An attempt to reconstruct time and place of origin, and migration and diversification of the Megalosporaceae has been based on the palaeogeographical data provided by SMITH \& BRIDEN (1977) and on conclusions reached in preceding chapters of this book: 1. the distribution patterns; 2 , the limited dispersal capacities of most species; 3 . the phylogenetical reconstruction; and 4 . the ecological preference of the family for epiphytic habitats in humid, cool forests.

The earliest development of the Megalosporaceae has probably occured in palaeozoic times on the eastern parts of the Gondwana-shield, when this land mass reached to within the tropics. There are no direct indications, however, for such a development, but the conditions which led to the development of the Glossopteris-flora might have favored the evolution of the Megalosporaceae as well, and the family character of the long-lasting apothecium primordia may be an indication for an origin in a seasonless, tropical climate. Moreover the absence of close relatives of the Megalosporaceae, which could not be found during this study, would be explained in this way, because during the Triassic period the eastern part of Gondwanaland appears to have moved southwards, and due to the corresponding climatical changes the ancestors of the Megalosporaceae can be expected to have become extinct except for a few groups which survived in humid forests with a mild climate on the northcoast.

In the Jurassic period the eastern Gondwanic northcoast was possibly an important evolution centre for the Megalosporaceae, for palaeogeographical data suggest that this area was then situated on nearly the same latitude as nowadays New Zealand and Tasmania. These areas show nowadays the widest range of basic variation in Megalosporaceae in the world, by the occurence, mainly in humid, cool forests, of all three genera, Austroblastenia, Megaloblastenia and Megalospora. This suggests that humid and cool forests are an ancient habitat for these groups. In view of the latitude the existence of such forests along the northcoast of eastern Gondwanaland in the Jurassic period is very likely. Moreover the forests of New Zealand and Tasmania may form direct continuations of such mesozoic forests because coastal areas at the same latitude have been present continuously since the Jurassic time along the eastcoast of Gondwanaland. The possibility of this evolution centre is also supported by the (slight) preference of Megalosporaceae for Podocarpaceae like Phyllocladus and Podocarpus as phorophytes (cf. p. 184), both genera which are supposed to be of Mesozoic origin (FLORIN 1963), and by the author's observation of a rich Megalosporaceae 
flora in a forest near Otira (New Zealand) which was dominated by species of Podocarpus and Phyzzocladus.

Palaeogeographical data suggest that the northcoast of eastern Gondwanaiand has remained in a favorable position for the Megalosporaceae for about $50 \mathrm{mil}$ lion years and thus may have provided the opportunity for an accumulation of much genetical variation resulting in the differentiation of the genera Austroblastenia, Megaloblastenia and Megalospora, and probably also most of the spore types in Megalospora, the sulphurata-, atrorubicans-, tuberculosa- and lopadioides-type. However, the differentiation of the tuberculosa- and lopadioidestype might as well have been by the end of this period, because they are absent from New Zealand and New Caledonia, which islands are supposed to have become separated from the Australian mainland in the Cretaceous period. The small size of these islands might have slowed down the evolution of the Megalosporaceae to such extent that the primitive spore types are still dominant there, whereas they have been replaced on the Australian mainland largely by species with tuberculosa- or lopadioides-type spores.

The assumption of an ancient evolution of the Megalosporaceae is supported by the present-day distribution patterns. These differ clearly from those of most angiosperm families which are supposed to date back to the Tertiary and have their basic distribution centres in former Laurasia and western Gondwana1and (RAVEN \& AXELROD 1974). On the contrary the distribution patterns of the Megalosporaceae resemble those of a few phanerogam families considered to be primitive, e.g. Winteraceae (cf. LEROY 1978, p. 543), and among the Coniferae e.g. the genera Dacryditon and Podocarpus (Podocarpaceae), which existed already in the Jurassic period according to fossil evidence (FLORIN 1963). More common is this type of distribution pattern amongst hepatics, e.g. the genera Temoma and Paraschistochila (SCHUSTER 1979), which are considered to be derivatives of an old Gondwanic flora, and among the mosses Rhizogoniaceae, and to some extent Dicnemonaceae, Leptostomaceae and Rhacopilaceae have similar distribution patterns (cf. HERZOG 1926).

After the Jurassic period the eastern part of the Gondwanashield has moved northward again, to within the tropics. The corresponding climatic changes must have forced the Megalosporaceae into areas along the eastcoast of Gandwanaland (cf. Fig. 52). In addition, the northward movement was probably accompanied by the development of mountains along the northcoast, which may have brought mountain forests with a cool, humid climate within reach of the Megalosporaceae and enabled species with sulphurata-, atrorubicans- and tuberculosa-type spores to adapt themselves to tropical mountain habitats. The coccodes-type probably de- 
veloped in such mountains, because it is nowadays restricted to tropical mountains.

In New Guinea the conditions that thus arose, seem to have been conserved best. At present its mountain forests house the largest number of Megalospora species present in any single country (9). The altitudinal distribution of the species suggests that species with atrorubicans-type spores got adapted first to mountain habitats because they occur nowadays at the highest elevations. Species with coccodes-type spores probably evolved later, when a certain adaptation to a warmer climate was obtained, because they prefer lower elevations nowadays and are more or less restricted to tropical mountains.

The southward movement of the Malaysian shield since the early Jurassic times times, towards the northcoast of eastern Gondwanaland, and a presumed presence of mountains with humid, cool forests on this shield, must have provided a way for Megalospora species to spread from the northcoast of eastern Gondwanaland northwards, to Laurasia. Probably two such migrations have occured, an earlier one which resulted in the establishment of Megalospora atrombicans ssp. sendaiensis and the East-asian population of $M$. tuberculosa, and a later one when $M$. atrombicans ssp. atrombicans and plants of $M$. tuberculosa with usnic acid crossed (cf. Fig. 52). Besides via the Malaysian shield the first northward migration might also have been via the northward movement of the Indian shield, a route supposed for e.8. hepatics (SCHUSTER 1976, 1979) and in existence about 80 million years ago.

Another early migration route is suggested by the occurence in Africa and America of endemic, tropical mountain-inhabiting species of Megalospora with coccodes-type spores. For this distribution pattern a migration route must be postulated via mountains along the northcoast of Gondwanaland, over the future Indian part of the Gondwanic shield, and over future Africa (Fig. 52). Stepping stones in this route might have been the known mesozoic mountain areas of southeastern Africa, western Africa and the Guyana highlands. This migration route must have functioned before the end of the Cretaceous period, because after that time the division of western Gondwanaland must have become prohibitive for contacts between Africa and America. The close resemblance of the neotropical Megalosporae to the East African and Malaysian ones, as demonstrated by the distribution of e.g. Megalospora coccodes(Fig. 31 on p. 135), is in favor of such a tropical mountain hopping. Migration via temperate land is less likely because it would have been marked by the presence of descendents with coccodes-type spores in e.g. temperate South America. The considerable differences 


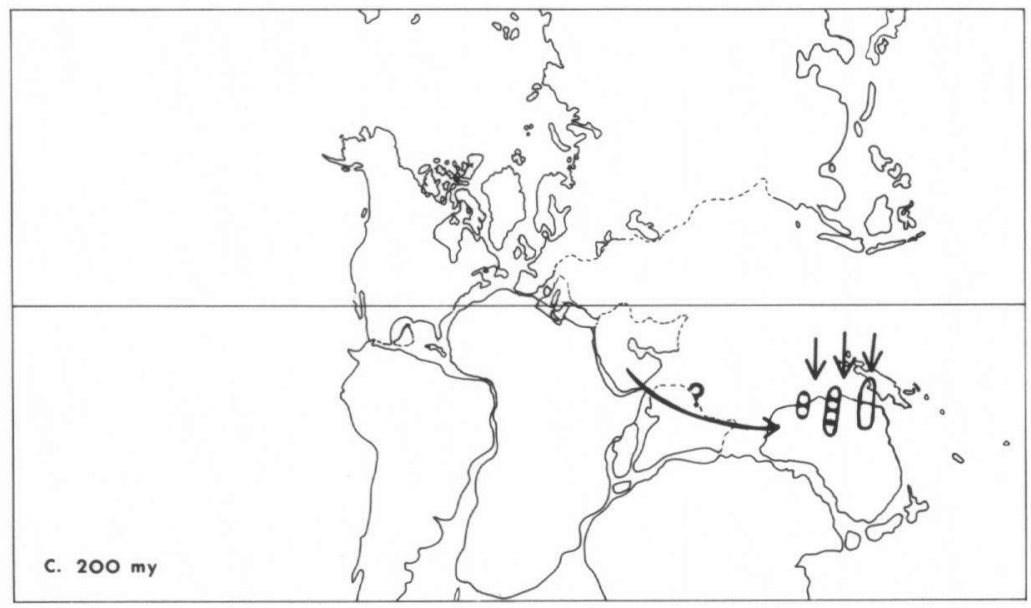

Figure 50. Supposed distribution and migration of the Megalosporaceae c. 200 million years ago.

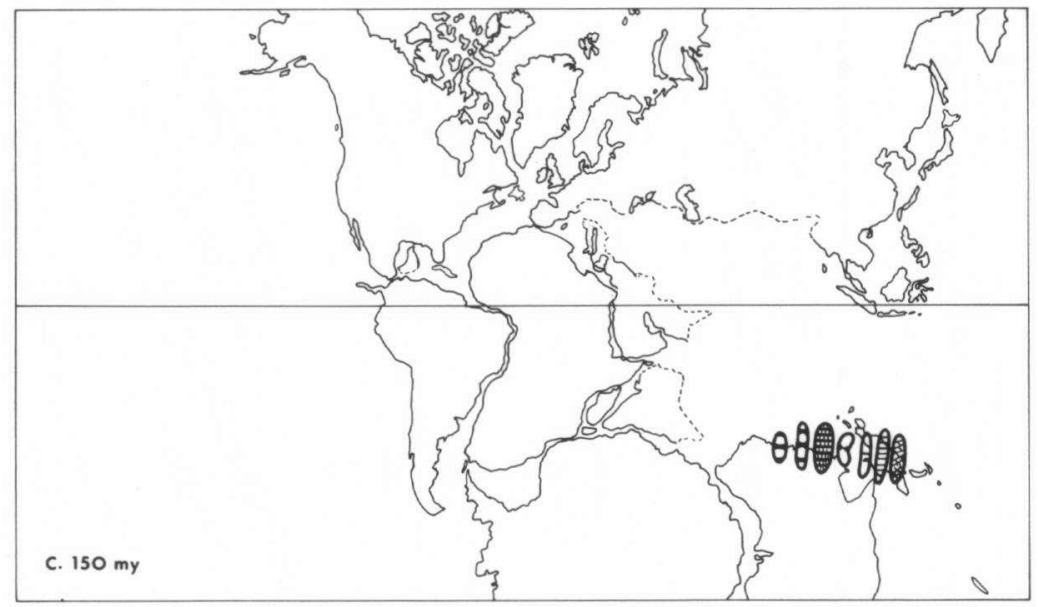

Figure 51. Supposed distribution and migration of the Megalosporaceae c. 150 million years ago. 


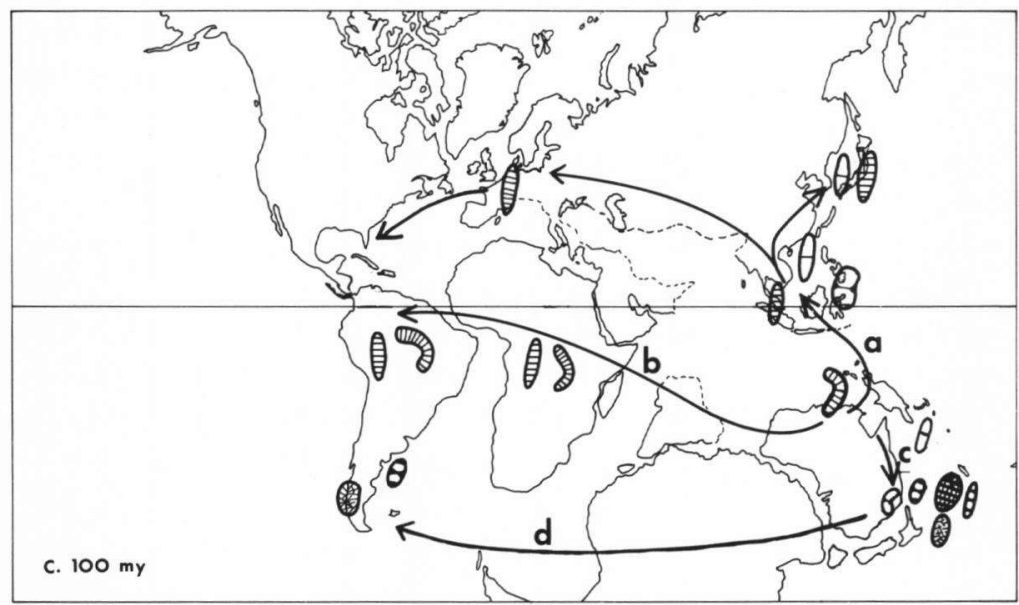

Figure 52. Supposed distribution and migration of the Megalosporaceae c. 100 million years ago.

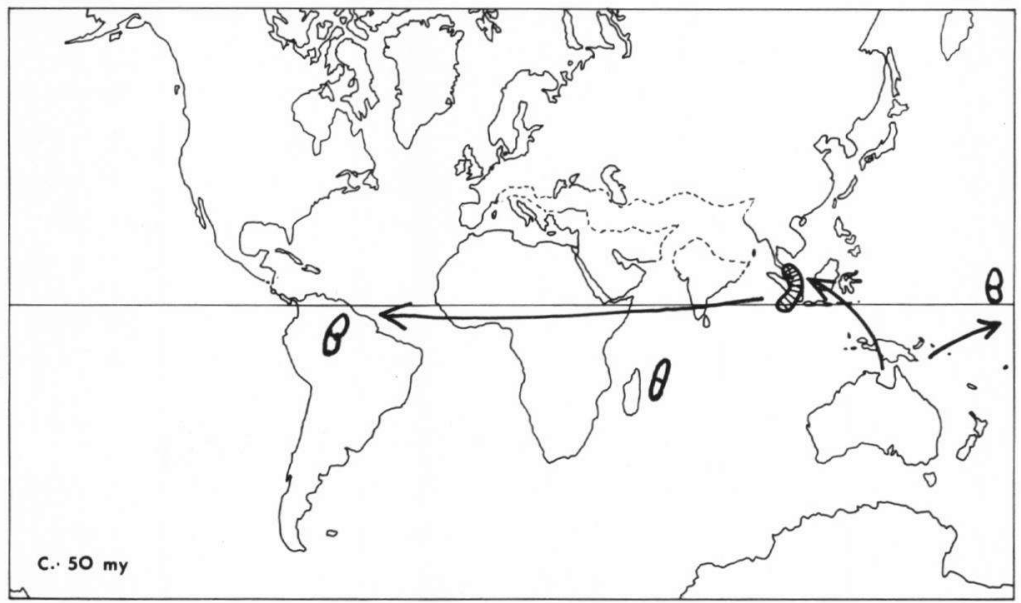

Figure 53. Supposed migrations of the Megalosporaceae, c. 50 million years ago. 
between the Megalospora-flora of the East African mountains and that of West Africa, however, does not completely fit this explanation. The West African species Megalospora maderensis and $M$. thomensis unexpectedly have an isolated position among the species with coccodes-type spores, e.g. by possessing usnic acid. Perhaps they are relics of a former varied Megalospora-flora which developed locally on early Tertiary mountains.

Similar transtropical migrations are postulated for angiosperms by e.g. RAVEN \& AXELROD (1974, p. 637). They assume two such routes, one on each hemispere. The southern one would be represented by e.g. Megalospora coccodes, whereas an exemple of the northern migration route might be in the distribution of $M$. tuberculosa (cf. Fig. 52). The northern migration route, along the northcoast of the Thetis sea where suitable humid forests must have been available for Megalosporaceae, is also postulated by van BEUSEKOM (1971, p. 416) for Meliosma (Sabiaceae).

A further migration route is indicated by the South American taxa Megaloblastenia marginiflexa var. dimota and Megalospora kalbii, which have their closest relatives in Australia and New Zealand (cf. Fig. 17 on p. 90). As is shown by e.g. SCHUSTER (1979) inhabitable land connections must have existed between the two areas, probably via the Antarctic shield when it was in another position, c. 400 million years ago. For Megalobiastenia marginiflexa the possibility of a more recent long-range dispersal should not be ruled out, however, because the resemblance between the Cbilean population and the New Zealand and Australian populations is very strong.

The limited diversification in the tropical representatives with atrorubicans-, sulphurata- and tuberculosa-type spores, viz. Megalospora atrorubicans ssp. atrombicans, $M$. sulphurata and $M$. tuberoulos $\alpha$, as compared with the extensive speciation in the group with coccodes-type spores, suggests that the spreading of the former three spore types is of a more recent date. The first two species might even have spread after the division of the Gondwanic shield, in view of their apparent long-range dispersal capacities, demonstrated by their occurence on the Hawaiian Islands (cf. p. 186). For M. tuberouZosa a spreading to America at last in the early Tertiary must be assumed.

The most recent developments are probably the appearence of local isidiate or sorediate populations, e.g. in Megalospora sulphurata, $M$. tuberculosa and $M$. compyzospora. These are most likely to have developed after the species had reached their present locations, e.g. in the Tertiary, in view of their limited distributions. 
Sumarising (cf. Fig. 50-53), the origin of the genera of the Megalosporaceae is supposed to be before the Jurassic period, at first in tropical areas of the Gondwanic shield, and later in humid coastal forests. During the Cretaceous period the basic variation now present in the Megalosporaceae must have been in existence, and mountain forest habitats became occupied in the northeastern parts of Gondwanaland. From this evolution centre three main migration routes can be traced: 1. the genus Megaloblastenia and Megalospora kalbii probably reached South America via temperate areas on the Gondwana shield;

2. contact between the northeastern Gondwanaland and Laurasia led to a spreading of Megalospora species over Malaysia, East Asia and westwards, to Europe and probably North America, along the northcoast of the Thetis sea. 3. a third route is of mountain species directly westwards via the future Mascarene Islands, East Africa and West Africa to the neotropics. 
References

ACHARIUS, E. 1803 Methodus qua omnes detectos Lichenes...("Methodus Lichenum"), Stockholm.

ANDERSON, R. A. 1964 The genus Lecidea (Lichenised Fungi) in Rocky Mountain

National Park, Colorado. University of Colorado, Ph. D. thesis. University

Microfilms, Inc., Ann Arbor, Michigan.

ASAHINA, Y. 1944 Lichenologische Notizen 25. J. Jap. Bot. 20: 129-134.

BABINGTON, c. 1855 Lichenes, pp. 266-311 in: J. D. HOOKER, Botany of the Ant-

arctic voyage of $\mathrm{H}$. M. Discovery ships Erebus and Terror, in the years

1839-1843. II Flora Novae Zelandiae. Part II, Flowerless Plants. London.

BARKMAN, J. J. 1958 Phytosociology and Ecology of Cryptogamic Epiphytes. Assen. BELANGER, C. \&ORY DE SAINT VINCENT 1846 C. Botanique, Part 2, Cryptogamie,

in: C. BELANGER, Voyage aux Indes Orientales par le Nord de l'Europe. BELLEMERE, A. 1967 Contribution à létude du développement de 1'apothécie chez

les discomycètes inoperculés. Bull. Soc. Mycol. France 83: 393-640, 753931.

BEUSEKOM, C. F. van 1971 Revision of Meliosma (Sabiaceae), section Lorenzanea excepted, living and fossil, geography and phylogeny. Blumea 19: 355-529. CIFERRI, R. \& R. TOMASELLI 1953 Saggio di una sistematica micolichenologica.

Atti Istit. Bot. Univ. Lab. Crittog. Pavia ser. 5, 10: 25-84.

CULBERSON, C. F. \& H. KRISTINSSON 1970 A standardized method for the identifi-

cation of Lichen products. J. Chromatogr. 46: 85-93.

DELISE 1830 in A. P. de CANDOLLE, Botanicon gallicum, ed. 2, part 2, ex herbariis et schedis candollianis propriisque digestum a J. E. DUBY.

DIBBEN, M. J. 1980 The Chemosystematics of the Lichen Genus Pertusaria in North America North of Mexico. Milwaukee Public Mus, Publ. Biol, and Geol. 5. DODGE, C. W. 1971 Some lichens of tropical Africa. Beih. Nova Hedwigia 38. DUGHI, R. 1954 L'excipulum proprium des apothếcies des discolichens. Rev.

Bryol. Lichếnol. 23: 300-316.

DUNCAN, U. K. 1970 Introduction to British Lichens. Arbroath.

DURING, H. J. 1979 Life strategies of Bryophytes: a preliminary review.

Lindbergia 5: 2-18.

ESTABROOK, G. F. \& W. R. ANDERSON 1978 An estimate of phylogenetic relation-

ships within the genus Crusea (Rubiaceae). Syst. Bot. 3: 179-196.

FEE, A. L. A. 1824 Essai sur les Cryptogames des écorces exotiques officinales. Paris. 
FEE, A. L. A. 1837 Essai sur les Cryptogames des écorces exotiques officinales II. Supplément et révision. Paris.

FLORIN, R. 1963 The distribution of conifer and taxad genera in time and space. Acta Horti Bergiani 20: 121-312.

FLOTOW, J. von 1850 Mikroskopische Flechtenstudien. Bot. Zeitung (Berlin) 8: 361-369.

FRIES, E. 1831 Lichenographia europaea reformata. Lund.

GLUECK, H. 1899 Entwurf zu einer Vergleichenden Morphologie der FlechtenSpermogonien. (Thesis Heidelberg). Verh. Naturhist. -Med. Vereins Heidelberg N. F. 6(2): 78-216, $2 \mathrm{pl}$.

GRADSTEIN, S. R. 1975 A Taxonomic Monograph of the Genus Acrolejeunea (hepaticae) with an arrangement of the Genera of Ptychanthoideae. Bryophytorum Bibliotheca 4.

GROENHART, P. 1958 Two new Malaysian Lichens. Blumea, Supp1. 4: 107-112. HAFELLNER, J., H. MAYRHOFER \& J. POELT 1979 Die Gattungen der Flechtenfamilie Physciaceae. Herzogia 5: 39-79.

HAFELLNER, J. \& J. POELT 1979 Die Arten der Gattung Calop laca mit pluriloculären Sporen (Meroplacis, Triophthalmidium, Xanthocarpia). J. Hattori Bot. Lab. 46: 1-41.

HAFELLNER, J. \& A. BELLEMERB 1982 Elektronenoptische Untersuchungen an Arten der Flechtengattung Bomby Ziospora und die taxonomische Konsequenzen. Nova Hedwigia 35: 207-235.

HAFELLNER, J. \& A. BELLEMERE 1982b Elektronenoptische Untersuchungen an Arten der Flechtengattung Letrouitia gen. nov. Nova Hedwigia 35: 263-312.

HAFELLNER, J. \& A. BELLEMERE 1982c Elektronenoptische Untersuchungen an Arten der Flechtengattung Brigantiaea. Nova Hedwigia 35: 237-261.

HALE, M. E. 1973 Fine Structure of the Cortex in the Lichen Family Parmeliaceae Viewed with the Scanning-electron Microscope. Smithsonian Contr. Bot. 10.

HALE, M. E. 1974 ("1973") Growth, pp. 473-492 in: V. AHMADJIAN \& M. E. HALE, The Lichens. Academic Press, New York and London.

HELLBOM, P. J. 1896 Lichenaea Neo-Zeelandica seu Lichenes Novae Zeelandiae. Bih. Kongl, Svenska Vetensk,-Akad. Handl. Bd. 21, Afd. III, 13.

HENSSEN, A. 1968 (ontogenetic section, pp. 6-11) in: I. Mackenzie Lamb. Antarctic Lichens II. The genera Buellia and Rinodina. British Antarctic Survey Scientific Reports 61.

HENSSEN, A. H. M. JAHNS 1973 ("1974") Lichenes, Eine Einführung in die Flechtenkunde. Georg Thieme Verlag, Stuttgart.

HERTEL, H. 1967 Revision einiger calciphiler Formenkreise der Flechtengattung 
Lecidea. Beih. Nova Hedwigia 24.

HERTEL, H. 1977 Gesteinsbewohnende Arten der Sammelgattung Lecidea (Lichenes) aus Zentra1-, Ost- und Südasien. Khumbu Himal 6(3): 145-378, 55 Abb. HERZOG, T. 1926 Geographie der Moose. Jena.

HONEGGER, R. 1978 The ascus apex in lichenized fungi I. Lichenologist 10: 47-67.

HOOKER, J. D. T. TAYLOR 1844 Lichenes Antarctici. London J. Bot, 3: 634-658. HUE, A. M. 1891 Lichenes exotici.... Nouv, Archiv, du Muséum, sêr. 3, 3: 33192.

JAHNS, H. M. 1970 Untersuchungen zur Entwicklungsgeschichte der Cladoniaceen. Nova Hedwigia 20: 1-177.

KAERNEFELT, I. 1979 The brown fruticose species of Cetraria. Opera Bot. 46. KEUCK, G. 1977 Ontogenetisch-systematische Studie über Erioderma. Bibliotheca Lichenologica 6.

KILIAS, H. 1981 Revision gesteinsbewohnender Sippen der Flechtengattung CatilZamia MASSAL. in Europa (Lecanorales, Lecideaceae). Herzogia 5: 209-448. KNIGHT, C. 1875 Description of some New Zealand Lichens. Trans. B Proc. New Zealand Inst. 7: 356-367, P1. 23.

KNIGHT, C. 1883 On the Lichenographia of New Zealand. Trans. \& Proc. New Zealand Inst. 15: 346-358, P1. 35-38.

KOERBER, G. W. 1855 Systema Lichenum Germaniae. Breslau.

LEROY, J.-F. 1978 Composition, origin and affinities of the Madagascan vascular flora. Ann. Missouri Bot. Gard. 65: 535-589.

LETROUIT-GALINOU, M.-A. 1966 Récherches sur 1'ontogénie et 1'anatomie comparées de quelques Discolichens. Rev. Bryol. Lichénol. 34: 413-588, P1. 146.

LETROUIT-GALINOU, M.-A. 1969 The Apothecia of the Discolichens. Bryologist 71: 297-327.

Letroutt-Galinou, M.-A. 1973 Les Asques des Lichens et le type archaeascé. Bryologist 76: $30-47$.

LETROUIT-GALINOU, M.-A. 1974 ("1973") Sexual Reproduction, pp. 59-90 in: V. AHMADJIAN \& M. E. HALE (eds.), The Lichens. Academic Press, New York and London.

LINDSAY, W. L. 1866 Observations on New-Zealand Lichens. Trans. Linn. Soc. London 25: 493-560, P1. 60-63.

MAKHIJA, U. \& M. B. NAGARKAR 1981 Two new species of the lichen genus Megalospora from South-west India. Curr. Sci. 50(18): 823-824.

MASSALONGO, A. B. 1852 Ricerche sul1'autonomia dei licheni crostosi. Verona. MASSALONGO, A. B. 1860 Esame comparativo di alcuni generi di licheni. Atti I. 
R. Istit. Veneto ser. 3, 5: 247-276, 313-337.

MEACHAM, C. A. 1980 Phylogeny of the Berberidaceae with an Evaluation of classifications. Syst. Bot. 5: 149-172.

MEACHAM, C. A. 1981 A manual method for character compatibility analysis. Taxon 30: 591-600.

MEYEN, F. J. F. \& I. de FLOTOW 1843 Lichenes, in: F. J. F. Meyen's Beiträge zur Botanik, gesammelt auf einer Reise um die Erde. Verh. Kaiserl. Leopo1d.-caro1. Akad, Naturf. 19, Supp1. 1: 209-232.

MONTAGNE, C. 1848 Sixième Centurie des plantes cellulaires exotiques nouvelles. Décades I et II. Ann. Sci. Nat., III série, Botanique, 10: 106-136. MOSER-ROHRHOFER, M. 1960 Homologe Geflechte der Flechtenpilze mit orthogonaltrajektorischem Tha1lusbau. Oesterr. Bot. Zeitschr. 107: 249-264.

MURLLER ARG., J. 1881 Lichenologische Beiträge 13. Flora 64: 225-236. MUELLER ARG., J. 1882 Lichenologische Beiträge 15 (Fortsetzung). Flora 65: 326-337.

MUELLER ARG., J. 1882b Lichenologische Beiträge 16. Flora 65: 483-490. MUELLER ARG., J. 1883 Revisio Lichenum Meyenianorum. Jahrb. Königl. Bot. Gart. Berlin 2: 308-319 (reprint Cramer, Lehre, 1967).

MUELLER ARG., J. 1886 Lichenologische Beiträge 24 (Fortsetzung). Flora 69: 286-290.

MUELLER ARG., J. 1887 Revisio Lichenum Féeanorum. Rev. Mycol. (Toulouse) 9: 82-98 (reprint Cramer, Lehre, 1967).

MUELLER ARG., J. 1891 Lichenes Myoshiani in Japonia a C1. Miyoshi lecti et a C1. Professore Yatabe communicati. Nuovo Giornale Bot. Ital. 23: 120-131 (reprint Cramer, Lehre, 1967).

MUELLER ARG., J. 1894 Conspectus systematicus Lichenum Novae Zelandiae. Bul1. Herb. Boissier 2, app. 1.

MUELLER ARG., J. 1894b Lichenes Usambarenses. Bot. Jahrb. 20: 238-298 (reprint Cramer, Lehre, 1967).

MUELLER ARG., J. $1894 \mathrm{c}$ Lichenes, Seconde Enumération, in: TH. DURAND \& H. PITTIER, Primitiae Florae Costaricensis. Bull. Soc. Roy. Bot. Belgique 32(1): 121-173.

NYLANDER, W. 1859 Lichenes in regionibus exoticis quibusdam vigentes. Ann. Sci. Nat., 4 série, Botanique, 11: 205-264.

NYLANDER, W. 1863 Lichenes, in: J. TRIANA \& J. E. PLANCHON, Prodromus Florae novo-granatensis. Ann. Sci. Nat., 4 série, Botanique, 19: 286-382; 20: 228-279.

NYLANDER, W. 1867 Lichenes, Additamentum, in: J. TRIANA \& J.-E. PLANCHON, Pro- 
dromus Florae Novogranatensis. Ann. Sci. Nat., 5 série, Botanique, 7: 301354.

NYLANDER, W. 1869 Lichenes in Brasilia a Glaziou collecti. Flora 52: 117-126.

NYLANDER, W. 1886 Lichenes insulae San Thomé. Flora 69: 171-178.

NYLANDER, W. 1888 Lichenes Novae Zelandiae. Paris (reprint Cramer, Lehre,

1967).

NYLANDER, W. 1890 Lichenes Japoniae. Paris (reprint Cramer, Lehre, 1967). POELT, J. 1965 Zur Systematik der Flechtenfamilie Physciaceae. Nova Hedwigia 9: 21-32.

POELT, J. 1974 ("1973") Classification, PP. 599-632 in: V. AHMADJIAN \& M. E. HALE (eds.), The Lichens. Academic Press, New York and London.

POELT, J. \&. MAYRHOFER 1979 Studien über Ascosporen-Typen der Flechtengattung Rinodina. Beih. Sydowia 8: 312-331.

POELT, J. \& J. HAFELLNER 1980 Apatoplaca - genus novum Teloschistaceamm (Lichenes). Mitt. Bot. Staatssamml. München 16: 503-528,

RAVEN, P. H. \&. I. AXELROD 1974 Angiosperm biogeography and past continenta1 movements. Ann. Missouri Bot. Gard. 61: 539-673.

RIDDLE, L. W. 1912 An enumeration of lichens collected by Clara Eaton Cummings in Jamaica 1. Mycologia 4: 125-140.

RIDDLE, L. W. 1917 Some noteworthy lichens from Jamaica. Bu11. Torrey Bot. Club 44: 321-330, P1. 21 .

ROSE, F. 1976 Lichenological Indicators of Age and Environmental Continuity in Woodlands, pp. 279-307 in: D. H. BROWN, D. L. HAWKSWORTH \& R. H. BAILEY, Lichenology: Progress and Problems. Academic Press, London-New York-San Francisco.

SANTESSON, J. 1970 Anthraquinones in Calop Zaca. Phytochemistry 9: 2149-2166.

SANTESSON, R. 1952 Foliicolous lichens I, a revision of the taxonomy of the obligately foliicolous, lichenised fungi. Symb. Bot. Upsal. 12(1).

SAVILLE, D. B. O. 1968 Possible Interrelationships between fungal groups, in: G. C. AINSWORTH \& A. S. SUSSMAN, The Fungi, vol. III. Academic Press, New York-London.

SCHUSTER, R. M. 1969 Problems of antipodal distribution in lower land plants. Taxon 18: 46-91.

SCHUSTER, R. M. 1976 Plate tectonics and its bearing on the Geographical Origin and Disperal of Angiosperms, in: C. B. BECK, Origin and early evolution of the angiosperms. Columbia University Press, New York.

SCHUSTER, R. M. 1979 On the persistence and dispersal of transantarctic Hepaticae. Canad. J. Bot. 57: 2179-2225. 
SHIRLEY, J. 1894 Notes on tasmanian lichens. Pap. \& Proc. Roy. Soc. Tasmania for 1893: 214-219.

SMITH, A. G. \& J. C. BRIDEN 1977 Mesozoic and Cenozoic Paleocontinental Maps. Cambridge University Press, Cambridge etc.

SMITH \& SOWERBY 1807 English Botany, ed. 1: 1683.

SPRENGEL, C. 1827 Caroli Linnaei Systema Vegetabilium editio decima sexta, vo1. 4, pt. 1. Göttingen.

STACE, C. A. 1980 Plant Taxonomy and Biosystematics, Edward Arnold, London. STAFLEU, F. A. c.s. 1978 International Code of Botanical Nomenclature, Regnum Vegetabile 97.

STEIN, B. 1883 Die von Dr. Schadenberg in Mindanao und von R. Fritze in Madeira gesammelten Flechten. 60 Jahresber. Schles. Ges, vaterl. Cultur: 227-234.

STEIN, B. 1888 Ueber afrikanische Flechten. 66 Jahresber. Schles. Ges, vater1. Cultur: 133-142.

STIRTON, J. 1874 Descriptions of some New Zealand Lichens, collected by John Buchanan in the province of Wellington. Trans. \& Proc. New Zealand Inst. 6: 235-241.

STIRTON, J. 1875 Additions to the Lichen-flora of New Zealand. J. Linn. Soc. Bot. 14: 458-474.

STIZENBERGER, E. 1862 Beitrag zur Flechtensystematik. Ber. Thätigk. St. Ga11ischen Naturwiss. Ges. 1862: 124-182.

SWINSCOW, T. D. V. H. KROG 1975 The genus Pyxine in East Africa. Norw. J. Bot. 22: 43-68.

SWINSCOW, T. D. V. \& H. KROG 1981 The genus PhyZlopsora, with a report on East African species. Lichenologist 13: 203-247.

TAVARES, C. N. 1952 Contributions to the Lichen Flora of Macaronesia I. Lichens from Madeira. Portugaliae Acta Biol. III(3): 308-391, P1. 1-3.

TAVARES, C. N. 1958 Contributions to the Lichen Flora of Macaronesia II. Additions and corrections. Bol. Soc. Broter. 32 (2A série): 225-235, P1. 1-2. TAYLOR, T. 1847 New Lichens, principally from the Herbarium of Sir William J. Hooker. London J. Bot, 6: 148-194.

тHомSON, J. พ. 1968 ("1967") The lichen Genus Cladonia in North America. University of Toronto Press, Toronto.

TOUW, A. 1971 A taxonomic revision of the Hypnodendraceae (Musci). Blumea 19: 211-354.

TREVISAN, V. 1853 Spighe e Paglie, Scritti botanici varj, vol. I. Padova. TREVISAN, V. 1856 Brigantiaea, novum Lichenum genus. Linnaea 28: 283-298. TUCKERMAN, E. 1848 A synopsis of the lichens of the northern United States and 
British America. Proc. Amer. Acad. Arts \& Sci. 1: 195-285.

TUCRERMAN, E. 1864 Observationes lichenologicae. Observations on North American and other Lichens. Proc. Amer. Acad. Arts \& Sci. 6: 263-287 (reprint Cramer, Weinheim, 1964).

TUCKERMAN, E. 1872 Genera Lichenum: an arrangement of the north american

1ichens, Amherst (reprint Cramer, Weinheim, 1964).

TUCKERMAN, E. 1888 A Synopsis of the North American Lichens: Part II. New

Bedford (reprint Cramer, Weinheim, 1964).

VAINIO, E. A, 1921 Lichenes ab A. Yasuda in Japonia collecti (continuatio 1).

Bot. Mag. (Tokyo) 25: 45-79.

VAINIO, E. A. $192 \mathrm{lb}$ Lichenes Insularum Philippinarum III. Ann. Acad. Sci. Fenn. ser. $A, 15(6): 5-368$.

VEZDA, A. 1974 Foliicole Flechten aus der Republik Guinea (W. Africa) II. Acta Mus. Silesiae, ser. A, 23: 173-190.

VOBIS, G. 1980 Bau und Entwicklung der Flechten-Pycnidien und ihrer Conidien. Bibliotheca Lichenologica 14.

WALKER, F. J. \& P. W. JAMES 1980 A revised guide to microchemical techniques for the identification of lichen products. Bull. Brit. Lich. Soc. 46 (Supp1.): 13-29.

WATROUS, L. E. \& Q. D. WHEELER 1981 The out-group comparison method of character analysis. Syst. Zoo1, 30: 1-11.

WOLFF, G. P. 1905 Beiträge zur Entwicklungsgeschichte der Flechtenapothecien. Flora, Ergänzungsband 1905, Heft 1: 31-57.

YASUDA, A. 1935 Die Flechten Japans. Sendai.

ZAHLBRUCKNER, A. 1904 Neue Flechten. Ann. Mycol. 2: 267-270.

ZAHLBRUCKNER, A. 1907 Lichenes (Flechten), B. Spezieller Teil, pp. 49-240 in:

A. ENGLER \& R. PRANTL, Die natürlichen Pflanzenfamilien. I Teil, 1 Abt. ZAHLBRUCKNER, A. 1926 Lichenes (Flechten), B. Spezieller Teil, pp. 61-263 in:

A. ENGLER \& K. PRANTL, Die Natürlichen Pflanzenfamilien, 2 Auf1., Bd. 8. ZAHLBRUCKNER, A. 1927, 1928, 1931 Catalogus Lichenum Germaniae, Bd, IV (1927), Bd. V (1928), Bd, VII (1931), Leipzig.

ZAHLBRUCKNER, A. 1941 Lichenes Novae Zelandiae a $\mathrm{Cl}$. H. H. Allan eiusque col-

1aboratores lecti. Denkschr. Akad. Wiss. Wien, Math.-Naturw. K1. 104: 249-380, 2 P1.

ZANTEN, B. O. van, \& T. Pócs 1981 Distribution and Dispersal of Bryophytes. Advances in Bryology 1: 479-562. 
Index of names in taxonomical treatment

This index contains page references to all names in the taxonomical part (Chapter 7 and 8 ). Underlined are the pages where the taxon in question is described. In italics are the pages where a remark on the taxon in question is given. In plain type are the pages where synonymy is given.

Austroblastenia: 82 pauciseptata: $8 \overline{2-84}, 86$ pupa: $84-86$

Bacidia

coccodes: 132

pachycarpa: 157

tuberculosa: 156

versicolor: 173

\section{Biatora}

coccodes: 132

marginiflexa: 89

pachycarpa: $120,157,163$

porphyritis: 157,162

taitensis: 126

tricolor: 183

tuberculosa: 156

versicolor: 173

Biatorina

subvigilans: 126

versicolor: 173

var. incondita: 174

Bilimbia: 170,171

pachycarpa: 157

Blastenia

endochromoides: 89,92

iodoma: 89

radomna: 89

taitensis: 126

Bombyliospora: 94

amplificans: 133

var. nigricans: 135

angela: 159

asahinae: 159

fo. nuda: 159

aureola: 170

australiensis: 150,155

buelliacaea: 159

cerinella: 170

chloritis: 158

coccodes: 132 conjuncta: 133

diplotypa: 170

dolichospora: 170

domingensis: 170

endoleucitis: 158

expansa: 158

flaveocrocea: 170

flavidula: 170

granularis: 158

gyrosa: 170

incana: 170

inflexa: 155

japonica: 158

fo. asahinae: 159

cinerea: 159

purpurascens: 159

laevigata: 159, 163

lamii: 143

leprolyta: 170

maderensis: 137

melanocarpa: 157

var. leprosa: 157

meyeri: 158

neocaledonica: 171

nigeriensis: 170

nigrata: 158

var. phaeospora: 158

pachycarpa: 157

pachycheila: 139

porphyritis: 157

pruinata: 145

quadrilocularis: 171

sinensis: 159

subnigrata: 159

thomensis: 146

thoroldi: 171

togoensis: 146

tuberculosa: 156

var, aberrans: 157

nigrata: 158

porphyritis: 157

subversicolor: 157

fo. geotropa: 157

macrocarpa: 133

ventricosa: 150 
Bombyliospora, continued versicolor: 173 vigilans: 132 zuluensis: 158

Bombyliosporomyces: 94 tuberculosae: 94,159

Brigantiaea: 167

leucoxantha: 182,183

Byssus

incanus: 170

Caloplaca: 171

radomma: 89

Catillaria

bicolorata: 178

camptotheca: 174

flavidoatra: 87

kabayanensis: 178

maquilingensis: 178

meizoophthalma: 178

microphthalma: 178

ophthalmocarpa: 179

pauaiensis: 179

stellenboschiana: 179

sulphurata: 125

var. lecanocheila: 126

ochrocheila: 125

phaeocheila: 125

\section{Catinaria: 177}

grossa: $176,177,178$

isidiza: $171-172,176$

microcarpa: 172, 176

versicolor: $131,132,133,171,172-177$ endochromoides: 89

Dumoulinia: 94

maderensis: 94,137

Haematomma

puniceum var. rufidulum: 174

Heterothecium: 93

sect. Bombyliospora: 94

Megalospora: 93

Psorothecium: 94

pachycheilum: 139

pauciseptatum: 82

porphyritis: 157

taitense: 126

tuberculosum: 156

var. pachycheilum: 139

porphyritis: 157 versicolor: 173

Lecanactis: 171

Lecania

sect. Platylecania: 94

amplificans: 94, 133

var. nigricans: 135

sulphureofusca: $112,151,179-181$

Lecanora

albidula: 89,93

alboatrata: 173,177

amplificans: 133

var. maderensis: 137

camptotheca: 174

sulphureofusca: 179

var. albidofusca: 179

sulphureorufa: 110

versicolor: 172

var, vigilans: 132

vigilans: 132,133

Lecidea

subg. Bombyliospora: 94

Megalospora: 93

Psorothecium: 94

amplificans: 133

atrobrunnea: 183

campylospora: 114,117

chloritis: 158,162

clathrata: 114,117

coccodes: 132

conjuncta: 133

dichroma: 174,175

diplotypa: 170

dolichospora: 170

endoleucitis: 158

expansa: 158

fibrillosa: 131

flavidoatra: 87,88

glaucescens: 174

grandis: 126

grossa: 178

incondita: 174

inflexa: 154

iodonma: 89

maderensis: 137

marginiflexa: $89,92,100,105,106$, 126

var. atrorubicans: 95

megacarpa: 126,129

megaspora: 126,129

melanocarpa: 133,157

melastegia fo. mesoleucodes: 178 
Lecidea, continued

meyeri: 158

nigrata: 158

var. phaeospora: 158

obturgescens: 175

pachycarpa: 157

pachycheila: 139

radomma: 89

robusta: 131

submarginiflexa: 99

sulphurata: 125

taitensis: $120,126,129$

* epiglauca: 115,117

thomensis: 146

togoensis: 146

tuberculosa: 133,156

fo, geotropa: 157 macrocarpa: 133

versicolor: $123,125,173$

var. argyrodes: 173

incondita: 174

major: 173

subtuberculosa: 123

vigilans: 132

vigilans: 132,148

\section{Lepraria: 171}

\section{Letrouitia: 170}

Lichen

atro-cinereus: 123

Lopadium

leucoxanthum: 182,183

pauciseptatum: 82

Megaloblastenia: 87

flavidoatra: $87 \overline{-8} 8,91$

marginiflexa: $88,89-93$

var. dimota: 93

marginif $\overline{\text { exa: }} 89-93$

Megalospora: 93-94 a.o.

affinis: 187 ,

albescens: $148-150,161$

allanii: $11 \overline{5,120}$

alpina: 181

atrorubicans: $95-100,106$

ssp. atrorubicans: $95-97,98,99,110$ australis: $96, \overline{97-9} 9$

sendaiensis : $96,98,99-100$

var. sendaiensis: 99

australiensis: $150-152,155,161,181$

bartlettii: $101 \overline{-102,112}$

biclipea: $17 \overline{7}$ bicolorata: 177

campylospora: $92,99,106,114-117$, $119,120,123,129$

carneorosula: 173

castanocarpa: 126

coccodes: $132-137,139,140,146$,

ssp. coccodes: $94,132-135,136$,

nigricans: $134,135-137,149$

cummingsiae: 126

dichroma: 174

dimota: 93

dispora: 182

duplicella: 182

flavidula: 95

fucata: 182

glaucescens: 174

gompholoma: $91,98,99,103-106$, $117,122,168$

8sp. fuscolineata: 103-104 gompholoma: $92,104,105-106$

granulans: $102, \underline{106-108}, 112$

grossa: 178

halei: $152-154,161,163$

hillii: $108-110,114$

ikomae: 182

inflexa: 154-156, 161

isidiza: 171

jamaicensis: 179,181

kabayanensis: 178

kalbii: $164-165,166,167,169$

knightii: $117-120,122,163$

lividocincta: 174

lopadioides: $165-168,169$

1utea: 182

maderensis: $94,137-139,146,148$

maquilingensis: 178

marginiflexa: $89,99,100$

marginiflexoides: 105

megacarpa: 126

megaspora: 126

meizoophthalma: 178

melanodermia: $119,120-123,129$

melina: 182

mesoleucodes: 178

microphthalma: 178

nipponensis: 126

ophthalmocarpa: 179

pachycarpa: 157

pachycheila: $139-141,146,148$

pachyloma: $12 \overline{6}$

papillifera: 126

pauaiensis: 179

premnee11a: 182 
Megalospora, continued pruinata: $134,141-146,148$

ssp. fusca: $\sqrt{41-143}, 146$ lamii: $\overline{143-144}, 146$

ssp. pruinata: $143,144,145-146$ queenslandica: $165,166,16 \overline{8-169}$ sanguinaria: 182

var. microcarpa: 182

simplex: 183

stellenboschiana: 179

submarginiflexa: 99, 100

subsanguinaria: 182

subtuberculosa: $117,119,123-125,129$

subvigilans: 126

sulphurata: $93,94,99,117,119,120$, $121,123,125-132,133$, $139,148, \overline{161,16}, 172$, 177,183

var. campylospora: 99, 114

galactocarpa: 120

genuina: 125

lecanocheila: 126,129

megacarpa: 126

nigricans: $130,131-132$

ochrocheila: 125,129

phaeocheila: 125,129

sulphurata: 125-130,131, 132

sulphureorufa: $102,107,110-112,181$

taitensis: 126

tasmanica: 183

taylori: 183

thwaitesii: 126

thomensis: 146-148

tricolor: $1 \overline{83}$

tuberculosa: $94,120,133,148,152$,

verruculosa: 126 $153,156-163,171$

versicolor: 99,173

var, argyrodes: 173

dichroma: 174

incondita: 174

lividocincta: 174

major: 173

microcarpa: 172

subtuberculosa: 123

vigilans: 132

testaceopallida: 173

var, nigricans: 131

weberi: $110,112-114$

Megalosporaceae: $79-82$ a.o.

Mycoblastus: $181,182,183$

affinis: 181,182

alpinus: 181

duplicellus: 182 fucatus: 182

hypomelinus: 182

melinus: 182

sanguinarius: 182

fo. microcarpus: 182

subsanguinarius: 182

Parmelia

coccodes: 132

Patellaria

sect. Bombyliospora: 94

Psorothecium: 94

atrorubicans: 95,100

australiensis: 150

biclipea: 177

chloritis: 158

var, nigrata: 158

conjuncta: 133

flavidoatra: 87

gompholoma: 105

granularis: 158

incondita: 175

lividocincta: 174

marginiflexa: 89

megacarpa: 126

megaspora: 13

melanocarpa: 157

melanodermia: 120,123

meyeri: 158

pachycarpa: 157

pachycheila: 139

pachyloma: 126

premneella: 182

pruinata: 145

subvigilans: 120,126

sulphurata: 123,125

var. epiglauca: 115,123

megacarpa: 126

vigilans: 132

sulphureofusca: 179

sulphureorufa: 110

tasmanica: 183

taitensis: 123,126

togoensis: 146

tuberculosa: 156

var. aberrans: 157

subversicolor: 156

ventricosa: 150

versicolor: 173

var. incondita: 174

lividocincta: 174

vigilans: 132

var. nigricans: 131

Psorotheciopsis: 182 


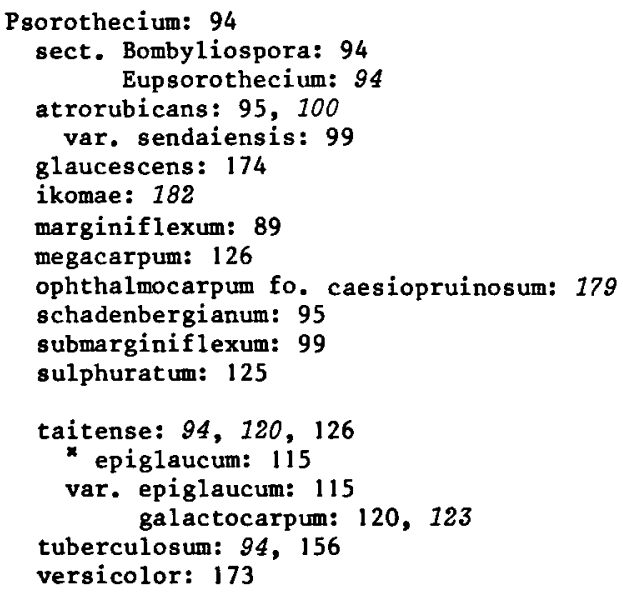




\section{Index of examined specimens}

To facilitate consultation by regional students, the specimens are arranged by their country of origin. Any data from chemical investigations are added to the specimen indications in brackets, by the following abbreviations: 1: 1ichexanthone present; p: pannarin present; u: usnic acid present; $A, B, C, D, E$ : unknown substance $A, B, C, D, E$ present in the apothecia.

\section{AZORES}

Megalospora tuberculosa (Fée) Sipm.

ST. JORGE: Mellau Calheta, H. Persson, 10.v.1937 (UPS).

\section{ARGENTINA}

Megalospora kalbii sipm.

RIO NEGRO: Llao Llao, c. $25 \mathrm{~km}$ NW of San Carlos de Bariloche, K. Kalb, 31.XII. 1980 (hb. KALB) $(p z,-)$

Megalospora sulphurata Meyen var. nigricans (Müll. Arg.) Riddle

MISIONES: Frontera, reforestación Gral Manuel Belgrano, A. R. Cuezzo \& E. de la Sota $2809,2818,2850$ (FH) (uz, AC); Iguazu, refugio El Yaguareté, A. R. Cuezzo \& E. de la Sota $2865(\mathrm{FH})(\mathrm{uz}, \mathrm{AC})$.

\section{ASCENSION}

Megalospora sulphurata Meyen var. aulphurata Green Mountain, P. W. James, 30.X.1976, 8.XI.1976 (BM) (Uz,AC)

AUSTRALIA (exc1. Lord Howe Island and Tasmania)

Megaloblastenia marginiflexa (Hook. \& Tayl.) Sipm. var. marginiflexa VICTORIA: Lake Tyers, F. R. M. Wilson 1380, L 4382 (NSW); Lake Watt Watt, Wilson 245 (G) (pz,B)

Megalospora australiensis (Mül1. Arg.) Sipm.

NEW SOUTH WALES: $56 \mathrm{mi}$ E of Walcha, W. A. Weber \& D. McVean, L-50038 (COLO) (pz, B). QUEENSLAND: Toowoomba, c. H. Hartmann 13,141 (G) (pz,-), 85 (w), s.n. (G) (pz,-), s.n. (US).

Megalospora gompholoma (Müll. Arg.) Sipm. ssp. fuscolineata Sipm.

VICTORIA: Black Spur, F. R. M. Wilson, L 3386, 21.III.1885 (NSW) (pz,AC); Bloomfield, F. R. M. Wilson, L 3384, 22.1V.1886 (NSW) (pz,ADE); Cobden, F. R. M. Wilson, L 3887, 3888, 20.I. 1886 (NSW) (pz,ADE); Mt. Macedon, F. R. M. Wilson, L 3385, IV. 1886 (NSW) (pz,A).

Megalospora inflexa (Knight) Sipm.

QUEENSLAND: Brisbane, F. M. Bailey, ex hb. Stirton (BM) (pz,AC).

Megalospora Lopadioides Sipm.

WESTERN AUSTRALIA: Beedelup Fa1ls, G. C. Bratt 67/448 (HO) (pz,-) 
Megalospora me Lanodermia Müll. Arg.) A. Zahlbr.

NEW SOUTH WALES: Grose River, R. Brown (BM, H) (uz,AC); Mill Creek, A. W. Archer 600 (U) (uz, AC); Mt. Kembla, An. 96 (NSW) (uz, AC); National Park, F. R. M. Wilson, L 3348 (NSW) (uz, AC); Paterson River, J. L. Boorman, VIII. 1906 (G); Point Lookout, E of Armidale, A. W. Archer 323 (U) (uz,AC), W. A. Weber \& McVean, L-47930 (COLO); River Styx State forest, SE of Armidale, W. A. Weber \& D. McVean, L-49348 (COLO); Stanwell Park, E. Cheel \& J. L. Boorman, in A. Zahlbr., Lich. rar. exs. 48 (G, W) (uz,-); $56 \mathrm{mi}$ E of Walcha, W. A. Weber \& D. McVean, L-50040 (COLO); Waterfall, hb. Wilson, L 3342, 3346 (NSW) (uz,AC). QUEENSLAND: Bailey 221, 567, 579 (G), A. Shirley 45 (W) (uz,-); Brisbane, Bailey 22l, 1542 (G) (uz,-); McPherson Range, P. F. Morris, L-50173 (COLO); Mt. Cordeau, Cunningham's Gap, A. W. Archer 1165 (U) (uz,AC); Mt. Mistake, F. M. Bailey, L 3351,3352 (NSW) (Uz,AC).

MegaLospora queens Landica Sipm.

QUEENSLAND: Atherton Tableland, Atherton Scrub, R. Mitche11, VIII.1911, L 3359 (NSW) (uz, AC).

Megalospora sulphurata Meyen var. sulphurata

QUEENSLAND: Atherton, Atherton scrub, R. Mitche11, VIII.1911, L 3422 (NSW) (uz, $\mathrm{ABC}$ ).

\section{BOLIVIA}

Megazospora tuberculosa (Fée) Sipm.

CAMPOL ICAN: Wedde 1,1848 (PC) (uz,B)

\section{BRASIL}

Catinaria versicolor (Fée) Sipm.

MINAS GERAIS: Monte Verde, Sipman 13046 (U); Sao Joao del Rey, G. A. Malme, Exp. I Regn. Lich. 291 (S); Sitio, E. A. Wainio, Lich. Bras. Exs, 1891, no. 720 (BM, M). RIO DE JANEIRO: S. Antonio, Glaziou 5519 (G, PC), 5520 (M, PC); Serra da Itatiaia, G. \& L. T. Eiten 7608 (US), Sipman 13626 (U). RIO GRANDE DO SUL: Santo Angelo pr. Cachoeira, G. A. Malme, Lich, austro-amer. Regn. 44 (H). SAO PAULO: Apiahy, Puiggari 381 (G,W), 1080 (W); Serra do Garraozinho, Sipman 12681 (U).

Megaloblastenia marginiflexa (Hook. \& Tayl.) Sipm. var. dimota (Malme) sipm. MINAS GERAIS: Monte Verde, Sipman 13035 (U). RIO DE JANEIRO: Glaziou 5003 (G, M, PC) (pz,B) (variety uncertain); Cascata pr. Pelotas, G. A. Malme, Exp. I. Regn. Lich. 799 (S); Santo Angelo pr. Cachoeira, G. A. Malme, Exp. I Regn. Lich. 877 (S); Silveira Martins, G. A. Malme, Exp. I Regn. Lich. 1186 (S, US). SAO PAULO: Apiahy, Puiggari 491 (G), 1522 (G); Praia de Pernibe, Sipman 13567 (U).

Megalospora pachycheila (Tuck.) sipm.

RIO GRANDE DO SUL: Hamburgerberg pr. Sao Leopoldo, G. O. Malme, Lich. austroamer. Regn. 40 (W) $(1 z,-)$. SAO PAULO, Cananeia, Sipman 13949 (U); Serra de Paranapiacaba, K. Kalb \& G. Plöbst, 13-14.V.1978 (hb. KALB) (1z,AC).

Megalospora sulphurata Meyen var. nigricans (Mül1. Arg.) Riddle MINAS GERAIS: Caldas, H. Mosén, 30.X.1875 (H); Serra da Mantiqueira, Vila Monte Verde, K. Kalb \& G. P1öbst, 7-11. IX.1978 (hb. Kalb) (uz,ABC), Sipman 12826, 12938, 12943, 13088 (U) (uz,AC); Sitio, E. A. Wainio, Lich. Bras. Exs. 572 (BM, $R$ in BM). RIO DE JANEIRO: Glaziou 1943 (G) (uz, AC), 3478 (G, M) (uz, AC), 5004 (M, PC) (uz, AC); Corcovado, Wawra \& Maly, Reise Maxim. 65I (W); Serra da Itatiaia, Sipman 13624, 13726 (U) (uz,AC); Serra dos Orgaos, Teresópolis, G. \& L. T. Eiten 7113,7414 (US). RIO GRANDE DO SUL: Canoas pr. Porto Alegre, G. O. Malme, Lich. austro-amer. Regn. 43 (H). SAO PAULO: Apiahy, Puiggari 472 (G, H, WELT) (uz,AC); Campos de Jordao, J. W. Harshberger 917 (BM); Ilha Comprida, Sipman 14127 (U). 
Megalospora sulphurata Meyen var. sulphurata

MINAS GERAIS: Serra da Mantiqueira, Vila Monte Verde, Sipman 12929, 12973 (U). SAO PAULO: Ilhabela, Sipman 13479 (U).

Megalospora tuberculosa (Fée) Sipm.

MATTO GROSSO: Coxipo-mirim pr. Cuyabá, G. O. Malme, Lich, austro-am. Regn. 39B (W); Serra do Roncador, P. W. Richards 6361 (BM). MINAS GERAIS: Serra da Mantiqueira, Vila Monte Verde, K. Kalb \& G. P1öbst, 7-II.IX.1978 (hb. KALB), Sipman $12822,12825,12957,13027,13942$ (U); Sitio, E. A. Wainio, Lich. Bras. Exs. 1891, nr. 573 (TUR) (z,-). PARANA: Faxinal, J. Puiggari 1231 (W). RIO DE JANEIRO: A. Glaziou 1943 (M) (pz,AC), 8.n. ((W) (uz,-); Pohl 4026 (W) (uz,-); Petropolis, Höhnel Lich. Bras. 59 (W) (pz,-); Serra da Itatiaia, H. Sipman 13714 (U). RIO GRANDE DO SUL: Cascata pr. Pelotas, G, O. Malme, Lich, austro-amer. Regn. 39A (W) (pz,-); Santo Angelo pr. Cachoeira, G. O. Malme, Lich, austroamer. Regn. 879B (US) ( $\mathrm{pz}, \mathrm{B}$ ). SAO PAULO: Apiahy, Puiggari 997, 1027, 1028 (G) (uz,-); Cananeia, Sipman 14159 (U); Ilhabela, Sipman 13380 (U); Serra do Garraozinho, Sipman 12727, 12728 (U); Serra de Paranapiacaba, K. Kalb \& G. Plöbst, 13-14.v. 1978 (hb. KALB) (pz, B, pz, C)

\section{BURUNDI}

Megalospora tuberculosa (Fée) Sipm.

Siguvyanye, J, Lambinon 74/1268 (LG) (uz, AC).

\section{CHILE}

Catinaria microcarpa (A. Zahlbr.) Sipm.

JUAN FERNANDES ISLANDS: Masatierra, Salsipuedes, C. \& I. Skottsberg, 20.II. 1916 (US, W).

Megaloblastenia marginiflesa (Hook. Tayl.) Sipm. var. marginiflexa Cordillera de Ranco, An. 3015 (BM, K in BM) (pz, B), Lechler (H).

\section{CHINA}

Megalospora tuberculosa (Fée) Sipm.

FUKIEN: Buong Kang, Yenping, H. H. Chung F-107 (FH), F 201 (US) (pz,AC); Kushan near Foochow, H. H. Chung F 367 (US) ( $p z, A C$ ). HUNAN: In monte Yün-schan prope urbem Wukang, Hande1-Mazzetti, it. sin. 1914-18, nr. 12082 (W) (pz,AC), 12347 (W). YüNNAN: in montium inter Dali (Talifu) et Hodjing, Handel-Mazzetti, it. sin. 1914-18, nr. 6553 (W) (pz,AC).

\section{COLOMBIA}

Catinaria versicolor (Fée) Sipm. CUNDINAMARCA: Acerradero, Lindig 777 (H-Ny1,); Bogota, Lindig 2682 (BR, G, H); Choachi, Lindig 811 ( $\mathrm{H}-\mathrm{Ny} \mathrm{l}_{\text {.) }}, 2772$ (G); Fusagasuga, Sipman \& Valencia 10304, 10305 (COL, U); Páramo de Guasca, E. Pêrez-Arbeláez 2226 (COL); Rio Dulce, Sipman c.s. 10366 (COL, U); Tequendama, Lindig 7 (BR). SANTANDER: Piedecuesta, Lindig 102 (BR, G, H-Nyl.). SANTANDER DEL NORTE: Paramo de Tama, M. E. Hale \& M. López Figueiras 45783 (MERF, US).

Lecania sulphureofusca (Fée) Müll. Arg. Lindig 2620, 2629 (?) (H-Nyl.). CUNDINAMARCA: Rio Dulce, Sipman c.8. 10368 (COL, U).

Megalospora coccodes (Bêl.) Sipm. ssp. coccodes Lindig 2812 (H-Ny1., UPS)

Megalospora sulphurata Meyen var. nigricans (Müll. Arg.) Riddle

CUNDINAMARCA: Acerradero, Lindig $2629 \mathrm{H}-\mathrm{Nyl}$.); Bogota, Lindig 747 (H-Ny1.), 
2625 (G), 2629 (BR); Villeta, Lindig 746 (H-Ny1.)

Megalospora tuberculosa (Fée) Sipm.

CUNDINAMARCA: Rio Dulce, Sipman c.s. 10367 (COL, U) (uz,AC); Honda, C. F.

Baker 47 (US) (uz,B).

\section{COSTA RICA}

Catinaria versicolor (Fée) Sipm.

Cordillera de Talamanca, S. C. Tucker 20373, 20374, 20413 (LSU); Las Cruzes

Botanical Garden, S. C. Tucker 20674, 20725 (LSU).

Lecania sulphureofusca (Fée) Müll. Arg.

PUNTARENAS: Las Cruzes Botanical Garden, Sipman 11901 (U).

Megalospora sulphurata Meyen var. nigricans (Müll. Arg.) Riddle

Tierra Blanca, Massif de l'Irazu, Tonduz (FH, G) (uz, AC)

Megalospora tuberculosa (Fée) Sipm.

Cordillera de Talamanca, San Pablo, K. Kalb \& G. P1öbst, 28.XII.1978 (hb. KALB)

(uz, BC); La Palma de San Ramon, A. M. Brenes 44 (US) (uz,AC); Las Cruzes Botacal Garden, Sipman 11877 (U), 11960 (U) (uz,AC).

\section{CUBA}

Megalospora pachycheila (Tuck.) Sipm.

Wright, Lich. Cub. 123 (W), 230 (L) (1z,AC); Loma del Gato, Cobre Range of

Sierra Maestra, L. Clement \& Roca 9994 (US) (1z,AC)

Megalospora tuberculosa (Fée) Sipm.

Anon. (H-Ny1. 18128) (pz, B); Wright, Lich. Cub, 228 (BM), (L) (pz,B), (L) (uz, B), 229 (L) (pz,ABC); La Prenda, B. Hioram 5468 (US), Manue1 5259 (US) (pz,ABC)

\section{DOMINICAN REPUBLIC}

Megalospora sulphurata Meyen var. nigricans (Mü11. Arg.) Riddle LA VEGA: nr. Constanza, H. A. Allard 17712 (US) (uz,AC).

\section{ECUADOR}

Megalospora tuberculosa (Fée) Sipm. NAPO: Baeza, Maas c.s. 3064 (U).

\section{FRANCE}

Megalospora tuberculosa (Fēe) Sipm.

Foret de Briquebec, Lebel. (L) (uz,B), hb. Montagne (L) (uz,B), Pelvet \& Delise, comm. Heget schweiler (W).

\section{GERMANY}

Megalospora tuberculosa (Fée) Sipm. BAYERN: Letten-wald zwischen Graswang und Linderhof, Arnold 593b (W); Oberammergau, Elmauer Stich, Schnabl (L) (uz,B); Partenkirchen, Arnold 593 (W).

\section{GUATEMALA}

Catinaria versicolor (Fée) sipm.

BAJA VERAPAZ: S of Santa Barbara, M. E. Hale 43830 (US). 


\section{HAITI}

Catinaria veroicolor (Fée) sipm.

Morne de Wejan, vicinity of Furcy, E. C. Leonard 4620 j (FH).

\section{HAWAIIAN ISLANDS}

Megalospora atrombicans (Ny1.) A. Zah1br. 8sp. atrombicans

HAWAII: C. N. Forbes 892H (US); Mt. Kalulu, Hualalai, Rock 73 (W). RAUAI:

0. Selling 6001 (S); Waimea distr., Kohua ridge, L. M. Cranwell, 0. Selling \& C. Skottsberg 563l (S); Waimea drainage basin, C. N. Forbes 1254k (US), 1259k (US). MAUI: C. N, Forbes 1335M (US); O. Selling ex L 5855 (S); NW flank of Haleakala Crater, Tucker 16663 (LSU); N or E slopes of Hukoyala, C. N. Forbes $1323 \mathrm{M}$ (US).

\section{Megalospora sulphurata Meyen var. sulphurata}

HAWAII: Black Sands Park, M. E. Hale 32898 (US); Mt. Kalulu, Hualalai, Rock 73 (W); Kilanea-Kilanea-ika, N. Rechinger 3323 (uz,ABC), C. Skottsberg 2057 (S); NE-slopes of Manna Kea, A. R. H. Lamberton 8305 (UPS); Saddle road area E of Pohakuloa, M. E. Hale 31497 (US); Volcanoes National Park, M. E. Hale 31782 (US), 31788 (US). KAUAI: Alakai bog trail, M. E. Hale 31345 (US); Kaholuamano, J. F. Rock, Lich. Sandw. 13 (W); Kokee Park, Kalalau Lookout area, M. E. Hale 31687 (US); Kokee, O. Selling 6019 (S); Weimea, Kokoluomano, B. P. G. Hochreuter 3513 (G); Koloa, U. Faurie, XII.1909 (UPS); Waimea drainage basin, C. N. Forbes 1292k (US). LANAI: C. N. Forbes 451L (US); Mehena Valley, J. F. Rock, Lich. Sandw. 114 (W). MAUI: Hakokolu, C. N. Forbes 1413m (FH); Honokahau drainage basin, C. N. Forbes 535M (US); Ralanae Sop, C. N. Forbes 1294m (FH) (uz, $A B C$ ); Puu Kukui, M. E. Hale 31241 (US); Waikapu, J. F. Rock, Lich. Sandw. 162 (W) (uz, ABC); Yao-valley, Faurie 657 (W). MOLOKAI: forest below Kolekole and Pelekana pali, F. Fagerlind \& C. Skottsberg 7106 (S). OAHU: Nuua.na-Kaliki ridge, C. Skottsberg, 13.VIII.1922 (S) (uz,A); Pauoa, A. A. Heller 2080 (US); Koolau Range, Pupukea forest reserve, F. Fagerlind \& C. Skottsberg 6890b (S); along Tanta1us, A. A. Heller 2165 (BM, E, FH) (uz, AC)

\section{INDIA}

Catinaria isidiza (Makhija \& Nagarkar) Sipm.

WEST INDIA: Maharashtra, Mahabaleshwar, M. B. Nagarkar 74.1796 (MACS), A. V. Prabhu \& M. B. Nagarkar 74,1820 (MACS).

Megalospora sulphurata Meyen ssp.sulphurata

KERALA: Km. 92 on Kumili-Devicolam road, M. E. Hale 46569 (US). WEST INDIA: Nilgiri Hills, Pyakara, near Ootacamund, P. G. Patwardhan \&. B. Nagarkar $73.984,73.1272$ (AMH) (uz, B).

Megalospora tuberculosa (Fée) Sipm.

KERALA: Gudampara, $30 \mathrm{~km}$ from Devicolam, M. E. Hale 46398 (US). TAMIL NADU: Nilgiri Hills, R. D. Anstead, 31.III. 1923 (US) (uz,ABC), G. H. Zell I/43 (W) (uz,C); Palni Hills, near Kodaikanal, M. E. Hale 43615 (US), 43859 (US); Pykara, M. E. Hale 50638 (US), 50640 (US) (uz,AC).

\section{INDONESIA}

Megalospora atrombicans (Ny1.) A. Zahlbr. ssp. atrombicans CELEBES: B. Rante Mario, G. Kjellberg 23L (S). JAVA: An. A6 no. 101 (a) (L); Tjibodas, v. Ooststroom 14295 (L); Toegoe, S. Kurz 496 (M), Kurz (H-Nyl.)

Megalospora coccodes (Bél.) Sipm, ssp. nigricans (Mü11. Arg.) Sipm. JAVA: An, in hb. Müller Arg. (G), An. nr. 32 pp (L, 910,165-1772); Tjibodas, 
v. Ooststroom 14287 (L) ( $\mathrm{pz}, \mathrm{ABC}), 14290 \mathrm{a}$ (L) (pz,ABC), 14293 (pz,ABC), 14436 (L) $(\mathrm{pz}, \mathrm{ABC}), 14528$ (L) (pz,AC), 14529 (L) (pa,ABC), 14671 (L) (pz,ABC).

Megalospora pruinata (Mü11. Arg.) Sipm. ssp. Zamii (Groenh.) Sipm. Zippel (L). JAVA: An. pl-1 (L, 910.201-2892 pr.p.) (pz,AC); Mt. Andjasmoro, P. Groenhart 4059 (L) ( $\mathrm{Pz}, \mathrm{ABC})$; Tjibodas, v. Ooststroom 14331 (L) (Pz,ABC), 14335 (L) $(\mathrm{pz}, \mathrm{AB}), 14340$ (L) $(\mathrm{pz}, \mathrm{AB}), \mathrm{C}$. \& D. v. Overeem, de Haas \& Bruggeman (W) $(\mathrm{pz}, \mathrm{A})$.

Megalospora sulphurata Meyen var. sulphurata

JAVA: Anon. in hb. Müller Arg. (G); Anon. (L) (910,201-2826), (910,201-2827), $(910,201-2832), 910,201-2833)(\mathrm{uz}, A B C),(910,201-2834),(910,201-2891)$ (uz,ABC), $(910,201-2892)(\mathrm{uz}, \mathrm{ABC}),(910,201-1893),(910,201-2894),(910,201-2895),(910$, 201-2896); Dozy ex hb. Léveillé (H-Ny1.); ex hb. Hooker (H-Nyl.); Junghuhn, Lich. Javan. 42 (L); Junghuhn ex hb. Räsänen (H), Lobh in hb. Hooker (K in BM); Mt. Andjasmoro, P. Groenhart 4060 (L); Mt. Ardjuno, P. Groenhart 4048 (L) (uz, ABC); Mt. Dorowati-Kukusan, P. Groenhart 4035 (L) (uz, BC), 4036 (L); Papandajan, G. Kjellberg 137L (S); Tjibodas, H. Boschma, I. 1921 (L) (uz,ABC), G. Kjellberg 102L (S) (uz, AC), v. Ooststroom 14147 (L), 14288 (L), 14330 (L), 14462 (L) (uz, AC), 14497 (L), 14527 (L), 14712 (L), van Leeuwein (TNS), v. Schiffner, It. Ind. 1893-94 no. 2940 (BM, TNS), 3256 (BM, TNS), Wm. Seifriz, 9.IX.1920 (US).

LOMBOK: G. Rindjani, J. Elbert 2191 (L). SUMATRA: Goenoeng Leuser, N. van Strien 2,15 (U).

Megalospora tuberculosa (Fée) sipin.

Anon. no. 32 (L) $(910,166-687)$, s.n. (L) $(910,182-10)$. JAVA: Buitenzorg, Anon. (L) $(910,182-9)$; Tjibodas, van Ooststroom 14292a (L), 14302 (L), 14303 (L), 14329 (L), 14685 (L).

\section{JAMAICA}

Lecania sulphureofusca (Fēe) Müll. Arg.

C. E. Cummings 138 (FH), 142 (FH); Newcastle, J. A. Cushman 24 (FH).

Megalospora sulphurata Meyen var. nigricans (Mül1. Arg.) Riddle

Hart. 54 ( $K$ in $B M)(u z, A C), 80$ ( $K$ in $B M)(u z, A C)$; Gordon Town, Joshua 54m (G) $(\mathrm{uz}, \mathrm{AC})$.

Megalospora sulphurata Meyen var. sulphurata

C. E. Cummings $129(\mathrm{FH})$.

Megazospora tuberculosa (Fée) Sipm.

Blue Mountains, Partland, Stony River Base Camp, B. D. Morley \& C. Whitefield 909 (BM) (uz,A)

\section{JAPAN}

Megalospora atrombicans (Nyl.) A. Zahlbr. ssp. sendaiensis (Räs.) Sipm. Akibu-mura, Y. Asahina 22, 24 (TNS); Arima Hot Spring, Y. Asahina, 12. I. 1929 (TNS); Mt. Benten, Y. Asahina, 1.IV.1936 (TNS) (uz,AC); Mt. Gongen, Matsuzo Ogata 156 (TNA); Mt. Hiei, M. E. Hale 29464 (US) (uz,AC); Jizoiwa, Y. Asahina 25.VII. 1933 (TNS); Kamiyama-mura, T. Sato 92 (TNS); Mt. Kenzan, F. Fujikawa, 20. VIII. 1934 (TNS) (uz,AC); Mt. Koya, Y. Numajiri 132, 373 (TNS); Mt. Kurama-yama, Y. Asahina, 4.IV.1939 (TNS); Nikko, Y. Asahina, 5.V.1931 (TNS), 12.VIII.1923 (TNS), R. Hashimoto 43, 44 (TNS), M. Miyoshi 92 (W); Mt. Sankaku, A. Yasuda 161 (TUR); Sendai, Anon. J 47 (W), A. Yasuda 108 (W), s.n. (W), E. Yishiba 47 (US), 138 (FH); Mt. Takao, Y Asahina 25 (TNS); Tosa, Miyoshi, VIII.1888 (S); Tottori, K. Yasuda, 23.IX.1929 (TNS) (uz,A) 
Megalospora sulphurata Meyen var. sulphurata

Ph. von Siebold (L) (doubtful record, cf. p. 130); Nichinan, M. E. Hale 29664 (US).

Megalospora tuberculosa (Fée) Sipm.

M. Miyoshi 8 (G); Mt. Amagi, Y. Asahina \& Togasi, Lich. Jap. Exsicc. 102 (W); Mt. Katsuma, S. Kurokawa \&. Kashiwadani, Lich. rar. crit. exs. 352 (L, U) ( $p z, A C)$; Mt. Kenzan, F. Fujikawa, 20.vIII.1934 (TNS); Mikunitoge, K. Tsunoda 66 (W) (pz,AC); Kiyosumi, M. Miyoshi, IV.1889 (W) (pz,-); Mororan, Faurie, Lich Jap. 38 (W) (pz,AC), 88 (W) (pz,AC); Nichinan, M. E. Hale 29598 (US); Tosa, M. Miyoshi 24 (G); Yezo, Faurie, Lich. Jap. 652 (W) (pz,-).

\section{LORD HOWE ISLAND}

Megalospora atrombicans (Nyl.) A. Zahlbr. ssp. australis Sipm.

J. C. Game 101 (BM) (uz,A), W. W. Watts, VII.1911 (NSW) (L 3358) (uz,AC).

Megalospora cf. campy Lospora (Stirton) Sipm.

J. C. Game 89/186 (BM) (pz,A), W. W. Watts, VII.1911 (NSW) (L 3358) (pz,A).

Megalospora cf. sutphureorufa (Nyl.) Riddle

W. W. Watts, VIII.1911 (NSW) (L 1843) (uz,AC?)

\section{MADAGASCAR}

Megalospora tuberculosa (Fēe) Sipm. N.0. de Madagascar, M. Pervillé 870 (PC) (uz,B)

\section{MADEIRA}

Megalospora maderensis (Krempelh.) Sipm.

B. Castillo da Peira 11, 34 (M) (uz,AC), R. Fritze 4 (M), Mandon, 1865 (M) (uz, AC).

\section{MALAYA}

Megalospora sulphurata Meyen var. sulphurata

PAHANG: Cameron Highlands, M. E. Hale 30163, 30199 (US); Gunong Brinchang-Tanah Rata, M. E. Hale 30466,30472 (US).

\section{MASCARENE ISLANDS}

Megalospora atromibicons (Ny1.) A. Zahlbr. ssp. atromibicans MAURITIUS: hb. Hooker, 1867 (BM).

Megalospora coccodes (Bél.) Sipm. ssp. coccodes

$\mathrm{Hb}$. Bory de St.Vincent in hb. Thuret, map 2094 (PC) (pz,AC). MAURITIUS: hb. Taylor, sheet 644 (FH, dup1. in G); Core Ayres, hb. Berkely ( $\mathrm{K}$ in BM). REUNION: Anon. ex hb. Montagne in hb. Müller Arg., comm. 1878 (G), Bélanger s.n. (PC), Lepervanche-Mezières 81 (PC),85 (PC-Thuret) (pz,AC), (G),851 (H-Nyl.).

Megalospora sulphurata Meyen var. sulphurata MAURITIUS: Anon. $7\left(\mathrm{H}-\mathrm{Ny} \mathrm{l}_{.}\right)$; M. Bogn Hub ( $\mathrm{K}$ in $\left.\mathrm{BM}\right)(\mathrm{uz}, \mathrm{AC})$; Mt. Ponce, ex hb. Kew (G).

Megalospora tuberculosa (Fée) Sipm.

Hb. Bory de St. Vincent (PC-Thuret) (Uz,AC). REUNION: Boivin (H-Ny1.).

\section{MEXICO}

Catinaria versicolor (Fēe) Sỉpm.

CHIAPAS: E1 Suspiro, $10 \mathrm{~km} \mathrm{~N}$ of Berriozábal, M. E. Hale 20240 (US); $18 \mathrm{~km}$ 
SE of San Cristóbal, M. E. Hale \& T. R. Soderstrom 20273 (US). MICHOACAN: Cerro Azul, Morelia, G. Arsène 4059 (US); $65 \mathrm{~km} \mathrm{E}$ of Morelia, M. E. Hale \& T. R. Soderstrom 20982 (US). VERACRUZ: NE of Huatusco, M. E, Hale \& T. R. Soderstrom 19538 (US), 19544 (US).

Megazospora pachycheila (Tuck.) sipm. VERACRUZ: Cordillera, H. Galeotto 6923 (PC) $(1 \mathrm{z}, \mathrm{AC})$.

Megalospora sulphurata Meyen var. nigricans (Müll. Arg.) Riddle PUEbla: "Honey Station", C. G. Pringle, P1. Mexic. 10749 (FH) (uz,AC), 15430 (FH) $(\mathrm{uz}, \mathrm{AC})$.

Megalospora sulphurata Meyen var. sulphurata

Ex hb. Nylander in hb. Coemans (BR); Orizaba, Fr. Mülier (H-Ny1. 18150, 18151). Megalospora tuberculosa (Fée) Sipm.

M. Ghiesbreght, 1845 (PC) (pz,B). CHIAPAS: E1 Suspiro N of Berriozäbal, M. E. Hale \& T. R. Soderstrom 20232 (US) (us,A?). OAXACA: trail to Cerro San Felipe, nr. Oaxaca, M. E. Hale \& T. R. Soderstrom 20701 (US). VERACRUZ: $15 \mathrm{~km} \mathrm{~S} \mathrm{of} \mathrm{Ca-}$ temaco, M. E. Hale \& T. R. Soderstrom 19800 (US) (uz,B); Cordillera, H. Galeotti 6935 (PC) (uz, B).

\section{NEW CALEDONIA}

Megalospora atrombicans (Ny1.) A. Zahlbr. ssp. atrombicans Vieillard (H-Nyl. 18149), Cl. Morière, leg. Vieillard 1859-60 (G); Kanala, Vieillard 1831 bis (H-Ny1. 18139). NOUMEA: Mount Koghi, D. J. Hill 11594, 11821 (BM), 11844 (BM) (uz,C). SARRAMEA: Col d'Amieu, D. J. Hil1 11862 (BM) (uz, AC), 11904 (BM), 11942 (BM). YATE: Bon Secours, D. J. Hil1 11794 (BM).

Megalospora hizlii Sipm.

South part, Rivière Bleue, D. J. Hill 11674 (BM). YATE: Plaine des Lacs, La Chute, D. J. Hi11 11653 (BM), 11656 (BM) (uz,AC); 11662 (BM) (uz,AC).

Megalospora sulphureorufa (Ny1.) Riddle

Wagap, Vieillard, 1863 (H-Ny1. 24485). ILE DES PINS: Tribu de Gadji, Baie des Crabes, D. J. Hill 12133 (BM). LIFU: Deplanche, 1864 (H-Nyl. 24483); Thiébault, 1864 (H-Nyl, 24484) ( (uz, AC), no. 22, c. 1865 (PC). NoumEA: Mount Koghi, D. J. Hi11 11515 (BM), 11566 (BM), 11566 a (BM). SARRAMEA: Co1 d'Amieu, D. J. Hil1 11939 (BM) (uz,-). YATE: Bon Secours, D. J. Hill 11788 (BM).

Megalospora sulphurata Meyen var. sulphurata

Compton 1738 (BM); inter St. Louis et Yaté, Balansa 1896 (G).

PAPUA NEW GUINEA

Megalospora albescens Sipm.

Mnt. Wilhelm, Sipman 15850, 15850b, 15850c (U) (pz,AC; pz,A; pz,-)

Megalospora atrombicans (Ny1.) A. Zah1br. ssp. atrombicans

Wau, Kunai Creek, Sipman 15827b (U) (uz,A).

Megalospora coccodes (Bêl.) Sipm. ssp. coccodes (Mül1. Arg.) Sipm.

Wau, Mnt. Kaindi, Sipman $15684 f$ (U) (pz,AC); Wau, Mnt. Missim, Sipman 15708 (U) (pz,AC); Mnt. Wilhelm, Sipman 16023 (U) $(\mathrm{pz}, \mathrm{AC}), 16024 \mathrm{~b}$ (U), W. A. Weber \& D. McVean L-48676 (COLO) ( $\mathrm{pz}, \mathrm{AC}$ ).

Megalospora granuZans Sipm.

Mnt. Giluwe, D. McVean 67139 (COLO); Mnt. Wilhelm, Kashiwadani 12308 (TNS) (uz, AC), Sipman 15872B (U) (uz,A), 15931 (U) (uz,A), 15963 (U) (uz,A), W. A. Weber 8 D. McVean, L-48427. (COLO), L-48670 (COLO) (Uz,AC). 
Megalospora cf. halei sipm.

Mnt. Wilhe1m, Sipman 15967 (U) (uz,B).

Megalospora pruinata (Mü11. Arg.) Sipm. ssp. fusca Sipm.

Wau, Mnt. Kaindi, Sipman 15648e (U) (pz,AC); Mnt. Wilhelm, Sipman 15834 (U) $(\mathrm{pz}, \mathrm{AC}), 15834 \mathrm{c}$ (U) $(\mathrm{pz}, \mathrm{A}), 16036 \mathrm{~b}$ (U) $(\mathrm{pz}, \mathrm{A})$, W. A. Weber D. McVean, L-48426 (COLO) $(\mathrm{pz}, \mathrm{AC}), \mathrm{D}$. McVean, L-48687 (COLO) (pz,AC).

\section{Megalospora sulphurata Meyen var. sulphurata}

Mnt. Albert-Edward, Kashiwadani 11594 (TNS) (uz,AC), 11783 (TNS) (uz,ABC), 11783 (TNS) (uz,AC); Daulo Pass, between Goroka and Chuave, W. A. Weber \& D. McVean, L-50254 (COLO); Kaisinik, c. $20 \mathrm{~km} \mathrm{SE}$ of Wau, Kashiwadani 10718 (TNS) (uz, ABC); Merimanta, by Wabag, D. McVean 67152 (COLO); Mnt. Né, W. Vink 17533 (L); Wau, Mnt. Kaindi, Kashiwadani 10587 (TNS) (uz,AC), 10634 (TNS) (uz, ABC), Sipman 15648 (U, UPNG) (uz,ABC), 15756 (U, UPNG) (uz,ABC), 15771 (U, UPNG) (Uz, $A B C$ ), Sipman 15827 (U, UPNG) (uz, ABC), W. A. Weber \& D. McVean, L-50474 (COL0), L-51941 (COLO); Wau, Mnt. Missim, Sipman 15699 (U, UPNG) (uz,ABC); Wau, road to New Guinea Timber Lease, P. van Royen 4399 (L), 4465 (L); c $2 \mathrm{~km}$ N of Woitape Airstrip, Kashiwadani 12052 (TNS) (uz,ABC), 12286 (TNS) (uz,AC); Mnt. Wilhelm, Sipman 16022 (U, UPNG) (uz,AC), $16024 \mathrm{c}$ (U) (uz,ABC), 16036 (U, UPNG) (uz,ABC), W. A. Weber D. McVean, L-48674 (COLO).

Megalospora tuberculosa (Fée) Sipm.

Mt. Ambua, W. Vink 17417 (L); Wau, Mnt. Kaindi, Sipman 15648c (U) (uz, AC); Mnt. Wilhelm, Sipman 15872c (U) (uz,-), 15957 (U, UPNG) (uz,AC), Sipman 15983 $(\mathrm{uz},-), 15993$ (U, UPNG) (uz,-); $16022 \mathrm{~b}$ (U) (uz,AC), 16024 (U, UPNG) (uz,-), $16036 \mathrm{c}$ (U) (uz,AC), D. McVean 67107 (COLO) (uz,-), W. A. Weber \& D. McVean, L-48439 (COLO).

Megalospora cf. tuberculosa (Fēe) Sipm.

Wau, Kunai Creek, Sipman 15827b (U) (uz,-?); Mnt. Wilhe1m, Sipman 16036d (U) $(\mathrm{uz}, \mathrm{B})$.

Megalospora weberi sipm.

Mnt. Wilhelm, Sipman 15872 (U, UPNG) (uz,A), 15930 (U, UPNG) (uz,A), 15967b (U) $(\mathrm{uz}, \mathrm{A})$, D. McVean 66212 (COLO) (uz,A), 6789 (COLO), W. A. Weber \& D. McVean, L 48452 (COLO) (uz,A), L-48680 (COLO) (uz,A).

\section{NEW ZEALAND}

Austroblastenia pauciseptata (Shirley) Sipm.

AUCKLAND: Mt. Te Ahora, J. K. Bartlett 16694 (hb. Bartlett). CANTERBURY: Springs Junction, Lewis Pass Scenic Reserve, Bartlett 16666 (hb. Bartlett). NELSON: Wangapeka track, Bartlett 16676 (hb. Bartlett). OTAGO: Lake Manapouri, Bartlett 16662 (hb. Bartlett) (pz,B), 16663 (hb. Bartlett) (pz,B). TARANAKI: Mnt. Egmont Nat1. Park, J. K. Bartlett 19396 (hb. Bartlett). WELLINGTON: Hihitahi State Forest, J. K. Bartlett 16099 (hb. Bartlett). WESTLAND: Mnt. Glasgow, J. K. Bartlett 16670 (hb. Bartlett) (pz,B); Lake Mahinapua, Bartlett 16665 (hb. Bartlett); 0'Connor River Swamp near Fox Glacier, Bartlett 16664 (hb. Bartlett) (pz,B); Otira, Sipman 16783 (US) $(\mathrm{pz},-), 16784$ (U) $(\mathrm{pz},-), 16785$ (hb. Bartlett), 16791 (U) $(\mathrm{pz},-), 16833$ (U) $(\mathrm{pz},-), 16839(\mathrm{BM})(\mathrm{pz},-)$.

Austrobzastenia prea Sipm.

HAWKES BAY: Kuripapango, Napier-Taikape Rd., J. Bartlett 16677 (hb. Bartlett) $(\mathrm{pz}, \mathrm{B})$. OTAG0: Cascade Cove, Dusky Sd., Galloway, 18.II.1969 (CHR). WESTLAND: Mnt. Glasgow, Bartlett 16671 (hb. Bartlett) (pz,B); Otira, Sipman 16779 (U) $(\mathrm{pz}, \mathrm{B}), 16788(\mathrm{BM})(\mathrm{pz}, \mathrm{B}), 16790$ (US) (pz,B), 16793 (U) (pz,B), 16837 (U) (pz, B). 
Megazoblastenia flavidoatra (Nyl.) Sipm.

NELSON: Pelorus Bridge scenic reserve, W. Martin, III. 1954 (CHR, 380509); Rangitoto Island, H. H. Allan (CHR, 162976) (Uz,ADE), (CHR, 374642) (Uz,AD). OTAGO: Dunedin, L. Lindsay, X.1867 (H-Nyl. p.m. 4438).

Megaloblastenia marginiflexa (Hook. \& Tayl.) sipm. var. marginiflexa Knight 25 (M), 85 (H-Ny1. 18192), 123 (H-Ny1. 18190) (pz,B). AUCKLAND: Kawakawa, hb. Hooker (BM); lake Okataina scenic reserve, S. C. Tucker 20264 pr.p. (LSU); Orewa, N. Goubitz, XI.1979 (U); Te Paki Trig Bush, J. K. Bartlett 19404 (hb. Bartlett); E of Warotapu valley, Rotorua Co., K. W. Allison, VII.1936 (CHR) ( $\mathrm{pz}, \mathrm{B})$. CANTERBURY: Akaroa, Birdling's F1at, T. W. Naylor Beckett L 31 (CHR) (pz,B); Cass, Sipman 16305 (U) (pz,B), 16306 (U) (pz,B); Craigieburn forest reserve, Sipman 16345 (U) (pz,B); Oxford, T. W. Naylor Beckett L 24 (CHR); Peel Forest nat1. park, G. C. Bratt $72 / 1355$ (HO) ( $\mathrm{pz}, \mathrm{B}$ ). OTAGO: Alton valley, Galloway, V. 1962 (CHR); Astronomer's Pt., Dusky Sd., Galloway, 13.II.1969 (CHR); Mt. Cargill, Dunedin, W. Martin 1851 (CHR); Cascade Cove, Dusky Sd., Galloway, 18.II.1969 (CHR); Flagstaff Hill near Dunedin, J. S. Thomson ZA 26 (CHR) (pz,B); Mnt. Hodges, Dusky Sd., Galloway, II/1969 (CHR). TARANAKI: Mnt. Egmont natl. park, J. K. Bartlett 19398 (hb. Bartlett), Tucker 20060 (LSU). WESTLAND: Franz Joseph Glacier, Tucker 19750 (LSU); Mnt. Glasgow, Bartlett 16672 (hb. Bartlett) (pz,B); Otira, Sipman 16776 (U) (pz,B).

Megalospora atrorubicans (Ny1.) A. Zah1br. ssp. australis Sipm. AUCKLAND: Kaueranga Valley, J. Bartlett 16606 (hb. Bartlett) (uz, AC); Te Paki Trig Bush, J. K. Bartlett 19403 (hb. Bartlett); Waiwera, J. K. Bartlett 16679 (hb. Bartlett) (uz, ?). CANTERBURY: Arthurs Pass, W. Martin 6221 (CHR) (uz,AC), 6466 (CHR) (Uz,AC), 732 I (CHR), s.n. (CHR, 380542) (uz,AC); Boyle River Lodge, Sipman 16737 (U) (uz,AC); Craigieburn forest reserve, Sipman 16323 (U) (uz,AC), 16351 (U) (uz,AC); Craigieburn stn., Arthurs Pass road, W. Martin, 6.XII.1969 (CHR) (uz, AC); Kelly's Hill, Arthurs Pass natl. park, Bartlett 16660 (hb. Bartlett) (uz,AC); Port Levy, Bank's Peninsula, T. W. Naylor Beckett L 47 (CHR) (uz,ACE); Tawera near Waimakariri, Arthurs Pass, P. W. James 1750/6 (BM). HAWKES BAY: Kaweka Range, Bartlett 16673 (hb. Bartlett) (uz,ACDE); Kuripapango, Rapier-Taikape rd., Bartlett 16674 (hb. Bartlett) (uz,AC). NELSON: Diamond Lake, Cobb Valley, Bartlett 16658 (hb. Bartlett) (uz,AC); Rangitoto Island, H. H. Allan (CHR, 300244); Ruby Lake, Bartlett 16654 (hb. Bartlett) (uz, AC), 16659 (hb. Bartlett) (uz,AC). OTAGO: Five Finger Peninsula, Galloway, 10.II.1969 (CHR); Lake Manapouri, W. A. Thomson, 1934 (CHR, 241732) (uz,AC); Milford Sound, Tucker 19981 (LSU); Silver Peaks near Dunedin, J. Scott Thomson ZA 307 (CHR) (uz,AC), ZA 609 (CHR, W) (Uz,AC), s.n. (CHR, 374741) (Uz,AC), H. H. Allan, 6.XII.1936 (CHR) (uz, AC); Tautuku Bush, J. Scott Thomson ZA 596 (CHR, W) (uz, AC); Stuart Mountains, W. A. Thomson ZA 426 (CHR, W) (uz,AC). WELLINGTON: E of Eastbourne, Tucker 19290 (LSU); Kaka Hi11, Buchanan 20 (CHR); Tinakori Hills, Buchanan 87 (BM, CHR) (uz,AC). WESTLAND: Lake Kanieri, W. Martin, 27.II. 1954 (CHR); upper Otira valley, Galloway, XI.1972 (CHR) (uz,AC); Otira, Sipman 16775 (U) (Uz,AC), 16782 (U) (uz,AC), 16836 (U) (uz,AC).

Megalospora bartlettii sipm.

AUCKLAND: Te Paki Trig Bush, J. K. Bartlett 1939 (hb. Bartlett), 19394 (hb. Bartlett) (uz, ABC).

Megalospora compy Zospora (Stirton) Sipm.

Knight 79a (H-Nyl., WELT) (pz,AC), hb. Knight vol. 53A, p. 21-23 (WELT), s.n. (BM, W), J. D. Hooker in hb. Taylor, sheet 642 (FH). AUCKLAND: near Auckland, Sinnot 105 (FH); Little Barrier Island, J. M. Prigley 3610 (BM); Chelsea, H. H. Allan ZA 471 (CHR, W); Coromande1, Sv. Berggren, IX.1874 (S); Henderson, H. H. Allan 181 (CHR, W) (pz,AC); Kaitara, Church Road, Bartlett 16681 (hb. 
Barlett) (pz,AC); Kaiwaka, Bartlett 16648, 16649, 16650, 16684 (hb. Bartlett) (pz,AC); Karamatura Stream Gorge, Waitakere Range, Bartlett $16624,16625,16627$ (hb. Bartlett) (pz,AC); Kaukapakapa, Bartlett 16639 (hb. Bartlett); Mamaku plateau, Bartlett 16602 (hb. Bartlett) (pz,ACE); Northcote Gully, B, Leland \& E. W. B. Chase, in J. E. Tilden, South Pacific Plants 232 (BM, COLO, E, FH, US) (pz,AC); Orewa, Bartlett 16632, 16633, 16635, 16637, 16640, 16643 (hb. Bartlett) (pz,AC); Tekuiti Hil1, Bartlett 16630 (hb. Bartlett); Tom Thumb track, Waitakere Range, J. Bartlett 16621, 16623 (hb. Bartlett) (pz,AC); Kokekoke, Waiwera hil1, Bartlett 16667 (hb. Bartlett) ( $\mathrm{pz}, \mathrm{AC}$ ); Waimihi, West Taupo, Bartlett 16685 (hb. Bartlett) (pz,AC); Mnt. William scenic reserve, Bartlett 16686 (hb. Bartlett) ( $\mathrm{pz}, \mathrm{AC})$. HAWKES BAY: Kuripapango, Rapier-Taikape road, Bartlett 16675 (hb. Bartlett) (pz,ACDE). NELSON: Lead Hil1s, J. S. Thomson ZA 665 (CHR) (pz, AC). OTAGO: Cascade cove, Dusky sound, D. Galloway, 19.II.1969 (CHR) (pz,ACDE); Longwood Range, NE-side, Galloway, II. 1962 (CHR) ( $\mathrm{pz}, \mathrm{AC}$ ); Te Anau, Lake Thomson, P. W. James 400/4 (BM). WELLINGTON: Kaka Hi11, Buchanan 11,124 (WELT) (pz,AC); Tararua Range, E. Chamberlain v 124 (CHR) ( $\mathrm{pz}, \mathrm{ACDE}$ ); Tinakori Hills, Buchanan 167 (WELT) ( $\mathrm{Pz}, \mathrm{ADE}$ ); Wellington, J. Buchanan 51 (BM), 185 (BM), s.n., rec. 11.II. 1882 (BM), Sinnot 13 (FH). WESTLAND: Greymouth, Helms 231,232 (H, W), W. Martin, III. 1954 (CHR) (pz,AC); Otira, Sipman 16777, 16781, 16787, 16792 (U) $(\mathrm{pz}, \mathrm{ACDE})$.

Megalospora gompholoma (Mü11. Arg.) Sipm. ssp. gompholoma

Buchanan 20 , s.n. (CHR), Collenso 821, 5317 (BM), Helms in F. v. Müller (G), hb. Hooker (BM, FH), Knight (H, M), hb. Knight, vo1. 53A, p. 11, 12, 13 (WELT). AUCKLAND: Kawakawa, hb. Taylor, sheet 642 (FH); Lake Okataina scenic reserve, S. C. Tucker 20264 (LSU); Tisitea, E. Chamberlain ZA 295 (CHR) ( $\mathrm{Pz}, \mathrm{ADE}$ ); Waikare Moana, A. E. Wade, 3-4.V.1966 (BM). AUCKLAND Islands: Enderby Island, P. W. James $1317 / 2$ (BM). CAMPBELL ISLAND: G. Poppleton, XI. 1960 (COLO). CANTERBURY: Oxford Bush, T. W. Naylor Beckett (CHR) (pz,ADE); Port Hills, Christchurch, H. H. Allan v 218 (CHR) ( $p z, A D E)$, s.n. (CHR) ( $z z, A D E)$. CHATHLAM ISLAND: Travers $117(M)$. HAWKES BAY: Kaweka range, Bartlett 16669 (hb. Bartlett) (pz,ADE). NELSON: Pelorus Bridge, W. Martin, III. 1954 (CHR) (pz,ADE). OTAGO: L. Lindsay, 1861 (H-Ny1. 18143, 18145); Dart valley, Survey Flat, Galloway XII.1967 (BM); Dunedin, Sv. Berggren, 1874-75 (S) (pz,ADE), L. Lindsey, 4.XI.1861 (H-Ny1. 18142); Dusky Sound, Cascade cove, Galloway, I. 1969 (CHR); Eaglington valley, W. Martin A 554 (BM, CHR) (pz, ADE); East Taeri Bush, L. Lindsay, 4.XI.1861 (E) (pz,ADE); Five Finger peninsula, Galloway, 20.II.1969 (CHR); Flagstaff Hill near Dunedin, Galloway, IV/1963 (CHR), J. S. Thomson ZA 37 (CHR) (Pz,AE); Mnt. Natkin, J. S. Thomson ZA 432 (CHR) (Pz,ADE); Nugget Point, Galloway, II. 1967 (CHR); Resolution Sd., Goose Cove, Galloway, 10.II.1969 (CHR); Saddle Hil1 near Dunedin, L. Lindsay, 26.X.1861 (E) ( $\mathrm{pz}, \mathrm{ADE}$ ); Taieri Mouth, W. Martin 844 (BM) (pz,ADE); Te Wae Wae bay, Galloway, II. 1962 (CHR); Waitati, Sv. Berggren, V. 1874 ( $S$ ) ( $\mathrm{pz}, \mathrm{ADE}$ ). STEWART ISLAND: Anchorage Sd., Port Pegasus, Galloway, 1.XII.1969 (CHR); Disappointment Cove, Galloway, 29.XI.1969 (CHR); Glory Cove, Galloway, 15.II.1967 (CHR) (pz,ACE); Noble Sd., Port Pegasus, Galloway, 30.XI. 1969 (CHR); Wilson Bay, Galloway, 29.XI.1969 (CHR). WELLINGTON: Kaitoke park and Water reserve, Tucker 19199 (LSU); Mauriceville, W. Gray 3 (US) (pz,A); Tinakora Hil1s, Buchanan 125 (CHR) (pz,ADE); Wellington, J. Buchanan 200, 217 (BM) (pz,ACE). WESTLAND: Bruce Bay, Bartlett 16655 (hb. Bartlett) (pz,ADE); O'Connor River, Fox glacier, Bartlett 16656 (hb. Bartlett) (pz,ADE); Greymouth, R. Helms conm. Eggerth., Arn. exs. 1240 (H), comn. v. Müller 21 (G); Haast river bridge, G. C. Bratt $72 / 1758$ (HO); Lake Kinieri near Hokitika, Bartlett 16682 (hb. Bart1ett) (pz,ADE); Lewis Pass, Sipman 16753 (U) (pz,AD); Otira, Sipman 16780, 16789 (U) ( $p z, A D)$.

Megalospora gompholoma (Müll. Arg.) Sipm. ssp. fuscolineata Sipm. WELLINGTON: Mauriceville, W. Gray 3 (US) ( $p z, A D E$ ). 
Megalospora knightii Sipm.

Knight 79 (H-Ny1., 18172, WELT-Knight), comm. Solms 1890 (G), hb. Knight, vol. $53 \mathrm{~A}$, P. $17,22,23,24$ (WELT) (uz, A; uz, AC), Sinclair, comm. Babington 1884 (G). AUCKLAND: Church road scenic reserve, Kaitaia, Bartlett 16680 (hb. Bartlett) (uz, B); Herekino, A. C. Poole v 145 (CHR) (uz, BCD); Hokianga, Sv. Berggren, 1874-75 (S); Kaitaia, Bartlett 16631, 16651 (hb. Bartlett); Mangonui, J. Bartlett 16652 (hb. Bartlett) (uz,BC); Orewa, Bartlett 16634 (hb. Bartlett) (uz,BC), 16638 (hb. Bartlett) (uz, BC), 16641 (hb. Bartlett) (uz, BC), 16642 (hb. Bartlett) (uz, BD); Tom Thumb Track, Waitakere Range, J. Bartlett 16620 (hb. Bartlett) (uz,ABCDE); Waiotira, Bartlett 16645 (hb. Bartlett) (uz,B), 16646 (hb. Bartlett); Waiwera, Bartlett 16661 (hb, Bartlett) (uz,A), 16690 (hb. Bartlett) (uz, $A B C$ ). WELLINGTON: Wellington, C. Knight (BM).

Megalospora subtuberculosa (Knight) sipm.

Knight 116 (H-Ny1. 18157, WELT-Knight), hb. Knight, vo1. 51, p. 14, 15 (WELT). AUCKLAND: Waiau scenic reserve, Coromandel Peninsula, J. K. Bartlett 18886 (hb. Bartlett) (uz,C); Karamatura stream gorge, Waitakere range, J. Bartlett 16626 (hb. Bartlett) (uz,C); Tom Thumb track, Waitakere range, J. Bart1ett 16622 (hb. Bartlett) (uz,AC); track above Huia stream, Waitakere range, E. E. Chamberlain, 22. I. 1961 (CHR) (uz,C); mnt. Te Ahora, J. K. Bartlett 16693, 16695 (hb. Bartlett) $(u z, A C)$.

\section{PANAMA}

Catinamia versicolor (Fée) sipm. CHIRIQUI: trail Cerro Punta-Alto Bespingo, volcan Chiriqui, M. E. Hale 44886, 45936 (US).

Megalospora tuberculosa (Fée) Sipm.

Serrania del Darien, west ridge of Cerro Tacarcuna massif, S. Mori \& A, Gentry 4406 (US).

\section{PERU}

Catinaria versicolor (Fêe) Sipm.

Casapi, Mathews (FH-Taylor sheet 645, H-Nyl. 18169, M); San Martin, Lazate, Rio Apisoncho valley, P. M. Holligan L 28 (BM); Sachapata, W. Lechler, p1. peruv. ed. R. F. Hohenacker 2562a (G, H-Ny1. 18194, L, M).

Megazospora tubercuzosa (Fẻe) Sipm. Carabaya, Weddell 1848, VI-VII. 1847 (PC)

\section{PHILIPPINES}

MegaZospora atrombicans (Ny1.) A. Zahlbr. ssp. atrombicans MINDANAO: Schadenberg 23 (G, WRSL).

Megalospora atromibicans (Ny1.) A. Zah1br. ssp. sendaiensis (Räs.) Sipm. LUZON: Mnt. Data, M. E. Hale \& J. Banaag 26095 (US) (uz, AC), 26383 (US).

MegaZospora coccodes (Bél.) Sipm. ssp. nigricans (Mūll. Arg.) Sipm. LUZON: Mt. Data, M. E. Hale \& J. Banaag 26140 (US) (pz,AC)

Megalospora sulphurata Meyen var. sulphurata BASILAN: c. $25 \mathrm{~km} N$ of Upper Canas, M. E. Hale \& J. Banaag 24913 (US). LUZON: Mnt. Banahao, C. F. Baker 6311 (H); Bangast, Baker \& Copeland 1370 (H); Mnt. Data, M. E. Hale \& J. Banaag 26132 (US), 26161 (US) (uz,ABC), 26233 (US); $5 \mathrm{~km}$ $S$ of Lucban, M. E. Hale \& J. Banaag 26967 (US); Manilla, anon. (G); Mnt. Mariveles, E. D. Merrill 3975 (BM) (uz,AB), 6258 (US) (uz,BC); Mayon volcano, W. Gruezo WM 3569 (COLO) (uz,AB); Pauai, R. C. McGregor, Bur. Sci. 8542 (US), 8560 ( $B M, W)(u z, A B C), 8653$ (BM) (uz, ABC); Mnt. Polis, R. C. McGregor, Bur. 
Sci. 20350 (BM, PH, W) (uz,ABC), 20353 (BM) (uz, BC); prov. Benguet, E. D. Merri11 7977 (W) (uz, ABC), 7999 (BM, W) (uz,AC), 12937 (BM, W) (uz, B). MINDANAO: Mnt. Candoon, Ramos \& Edano, Bur. Sci. 38890 (H) (uz, B); C. $40 \mathrm{~km} \mathrm{NW} \mathrm{of} \mathrm{Lianga,}$ M. E. Hale \& J. Banaag 24626 (US) (uz,ABC); c. $40 \mathrm{~km}$ SW of Butuan City, M. E. Hale \& J. Banaag 25008 (US) (uz,B). NEGROS: Canlaon volcano, E. D. Merrill, Bur. Sci. 6880 (BM) (uz, AC).

Megazospora tuberculosa (FẼe) Sipm.

LUZON: prov. Benguet, E. D. Merrili 7936 (US), 7959 (US).

PORTUGal (excl. Madeira, Sao Thome)

Megalospora tuberoulosa (FÉ) Sipm.

ESTREMADURA: Serra de Sintra, C. Tavares 67 (US).

RWANDA

Megalospora pruinata (Müll. Arg.) Sipm. ssp. pruinata Rutsiro, Lambinon 74-682 (LG) (pz,AC).

Megalospora tuberculosa (Fée) Sipm.

Birunga, Lambinon 72-695 (LG) (uz,AC); Forêt de Rugege, Lambinon 72-969 (LG)

$(\mathrm{uz}, \mathrm{AC}), 72-977$ (LG) (uz,AC), 74-849 (LG) (uz,AC).

\section{SABAH}

MegaZospora coccodes (Bêl.) Sipm. ssp. nigmicans (Mül1. Arg.) Sipm. Sosopodon shelter near Kundason, M. E. Hale 29131 (US).

Megalospora halei sipm.

Kinabalu national park, M. E. Hale 28048 (US) (uz,B), 28067 (US), 28671 (US), 29028 (US).

Megalospora pruinata (Mü11. Arg.) Sipm. ssp. Zamii (Groenh.) Sipm.

Kinabalu national park, M. E. Hale 28449 (US).

Megalospora sulphurata Meyen var. sulphurata

Kinabalu national park, M. E. Hale 28017, 28037, 28205, 28247, 28489, 28496, $28585,28594,28785,28819,28991,29062,29100,29217,29273$ (US); Sosopodon shelter near Kundason, M. E. Hale 29073, 29118 (US).

\section{SAMOA}

Megalospora sulphurata Meyen ssp. sulphurata Reinecke 55 (G).

\section{SAO THOME}

Megalospora thomensis (Ny1.) Sipm.

Mo1ler 937 (H-Ny1. 18124) (uz,AC), s.n., 1885 (N-Nyl, 18165).

Megalospora tuberoulosa (Fēe) Sipm.

A. Moller, 1885 (W) (uz,B?).

\section{SARAWAK}

Megalospora cf. tuberculosa (Fée) Sipm.

Gunong Mulu national park, B. Coppins 5000 (E) (uz,B), 5001 (E) (uz,B). 


\section{SOUTH AFRICA}

Megalospora tuberculosa (Fêe) Sipm.

Cape of Good Hope, Table mountain, Jelinek 325 (W) (uz,-); Natal, Zululand, Eshore, P. van der Bijl 184 (TUR).

\section{SRI LANKA}

Megalospora sulphurata Meyen ssp. sulphurata

Habgalla, Leighton 118 (BM) (Uz,ABC), (G) (uz,ABC), (S, WELT-Knight); Medanehtamwara, A. H. G. Alston 2266 (K in BM); Pedrotallegalle, E. Almquist, 1879 (H-Ny1. 18151, S); Rampodde, E. Almquist 1879 (H-Nyl, 18152, S); Sinharaja forest reserve, Sabaragamuwa prov., M. E. Hale 47133 (US).

Megalospora tuberculosa (Fée) Sipm.

Pedrotallegalle, A. Almquist, 15-22.XII.1879 (S).

\section{SURINAM}

Megalospora tuberculosa (Fée) Sipm.

v. Sypesteyn (L).

\section{SWITZERLAND}

Megalospora tuberculosa (Fée) Sipm.

Ober Uster, Zürich, C. Hegetschweiler in hb. Lojka, 817 (W).

\section{TAHIT I}

Megalospora sulphurata Meyen var. sulphurata H. N. Moseley, Challenger expedition, IX.1875 (BM, K in BM), Lépine (H-Nyl. $18177, \mathrm{PC})$.

\section{TAIWAN}

Megalospora sulphurata Meyen var. sulphurata Mnt. Arison, Toroyen, Y. Asahina F-181 (TNS, W) (uz, AB); Keitau, prov. Nantou, Y. Asahina, 23.XII.1933 (TNS); Raisha, prov. Taitung, Y. Asahina F-179 (TNS). Megalospora tuberculosa (Fée) Sipm. Rengechi, Y. Asahina F 186 (W) (pz,AC).

\section{TANZANIA}

Megalospora coccodes (Bél.) Sipm. ssp. coccodes

Knigo near Kwai, west Usambara, J. Brunnthaler, 21.VIII.1909 (W) (pz,C).

Megalospora pruinata (Mü11. Arg.) Sipm. ssp. pruinata

Usambara, Holst 1404, 1411, lich. Usamb. 163 (G) (pz,A?).

Megalospora sulphurata Meyen ssp. sulphurata

Tanga prov., Usambara mnts., Amani, R. Moberg $1491 \mathrm{~m}$ (UPS) (Uz,ABC), R. Santesson 23157,23368 (UPS) (uz,ABC).

Megalospora tuberculosa (Fée) Sipm.

Arusha prov., mnt. Meru, R. Santesson 23082 (UPS) (uz,ABC).

\section{TASMANIA}

Austroblastenia pauciseptata (Shirley) Sipm.

Adamson's falls track, G. Kantvilas 961/81 (HO) ( $\mathrm{pz}, \mathrm{B}$ ); Franklin river road, beyond HEC barrier, G. C. Bratt \& J. A. Cashin 71/964 (HO) (pz,B); S of Arthur r., Sumac S2, G. Kantvilas 319/81 (HO) (pz,B), 641/80; Mnt. Wellington, Bower 
Creek, W. A. Weymouth, 10.VIII.1889 (NSW, L 4385) (pz,?).

Megaloblastenia marginiflexa (Hook. Tay1.) Sipm. var. marginiflexa

Adamson's falls track, G. Kantvilas 954/81 (HO) (pz,B); Arve Loop, Arve valley, Geeveston, G. Kantvilas 272/81 (HO); Ben ridge, E of Ben Nevis, G. Kantvilas 102/81 (HO); Cheshunt, Archer (K in BM); mnt. Field, Sipman 16158 (U) (pz,B); Mnt. Wellington, Shoobridge track, G. C. Bratt \& J. A. Cashin 2011 (HO).

MegaZospora campyzospora (Stirton) Sipm.

McGregor Peak, G. C. Bratt \& J. A. Cashin 1476 (HO) (pz,ADE).

Megalospora gompholoma (Müll. Arg.) Sipm. ssp. fuecolineata Sipm.

hb. Hooker (BM) (Pz,ADE), (FH, H-Nyl. 18147); Mnt. Arthur, anon., L 3372 (NSW); Cheshunt, Archer (BM, $K$ in BM); Circular Head, hb. Hooker, nr. 1761 (K in BM); Hellyer gorge, $30 \mathrm{~km}$ SW of Burnie, A. W. Archer 939 (U) (pz,AE), G. C. Bratt \& M. H. Bratt 1825 (HO) (pz,ADE), W. A. Weber \& D. McVean, L-49645 (COLO).

Megalospora Zopadioides Sipm.

Mnt. Field, Sipman 16133 (U) (pz,A?); Gordon river gorge, Sipman 16081B; Islet lake, Wilmot range, $K$. Davies $75 / 1035$ (HO) (pz,B?); Lake Judd Forest, G. C. Bratt $73 / 917$ (HO) (pz,B); Junction creek, c $60 \mathrm{~km}$ WSW of Huonville (HO) (pz, B); Murchison highway S of Waratah, G. C. Bratt J. A. Cashin 2415 (HO) (pz, B); Mount Victoria track, G. C. Bratt \& K. M. Mackay 70/1345 (HO) (pz,-), 73/1209 (HO) $(\mathrm{pz}, \mathrm{B}$ ?).

\section{THAILAND}

Megalospora tuberculosa (FẼe) Sipm.

Prov. Chieng Mai, $20 \mathrm{~km}$ W of Chieng Mai, R, M. King C-229 (US) (uz, AC).

TOGO

Megazospora thomensis (Nyl.) Sipm.

Bismarksburg, Büttner, 1892 (G).

\section{TRINIDAD}

Megalospora tuberculosa (Fée) Sipm.

c. $4 \mathrm{mi}$ E of Valencia, M. E. Hale 38193 (US).

\section{UNITED STATES}

Megalospora pachycheila (Tuck.) sipm.

ALABAMA: Anon. (H-Ny1. 18123c) $(1 \mathrm{z}, \mathrm{C}$ ). FLORIDA: W. W. Calkins 75 (UPS) (1z,AC). MISSISIPPI: Anon. (H-Nyl. 18123c). SOUTH CAROLINA: Anon. (H-Nyl. 18123c). TEXAS: E. Hall in hb. Wiley, 1872 (US) $(1 \mathrm{z}, \mathrm{AC})$.

Megalospora tuberculosa (Fée) Sipm.

White Mountains, E, Tuckerman, 1847 (FH). ALABAMA: E.T,, Cl. Beaumont, L 6 (H-Nyl. 18127) (uz,A). FLORIDA: Eckfelt \& Calkins, hb. Willey (US) (uz, B); Lake County, Ocala National Forest, R. C. Harris 1952 (UPS), 2441-B (UPS); Sanford, S. Rapp in hb. Plitt, IV. 1906 (US) (uz,B). MASSACHUSETTS: Amherst, E. \& E. S. Tuckerman (FH) ( $\mathrm{pz}, \mathrm{C})$; hb. Willey, 1862-1898 (US) (pz,AC).

\section{VENEZUELA}

Catinaria versicolor (FÉe) Sipm. ARAGUA: Parque nacional Henri Pittier, Hertel 10729 (M), B. \& F. Oberwinkler \& J. Poelt, III.1969 (hb. Poelt). DISTRICTO FEDERAl: Caracas, Ernst 60, 189 (G), s.n. (BR). LARA: Barbacoas-Hato Arriba-E1 Tocuyo, M. López F, R. Smith 16612 (MERF); Sierra de Barbacoas, López F. 22210 (MERF, U); Serranfa Ziruma o Empa- 
lado, Lб́pez F. \& R. Wingfield 21535, 21537, 21542 (MERF, U), 21569 (MERF), 21600,21630 (MERF, U), López F. \& R. Smith 20817 (MRRF), 20856 (MERF, U). MERIDA: La Azulita-San Eusebio, M. López F. 13650 (MERF); La Carbonera, via Mérida-La Azulita, M. López-F. \& Keogh 9214, 9227, 9246 (US), M. López F., K. Amman, V. Wirth \& B. Irlet 18104, 18481 (MERF), M. López F. 26752 (MERF), M. E. Hale 42074 (US), M. E. Hale \& M. López F. 44002, 44080, 44102, 44107, 44130 (US); Between La Carbonera and E1 Pedregal, M. E. Hale \& M. López F. 44185, 44188 (US); Páramo de Guaraque, M. López F. 22698 (MERF, U); Entre Tovar y el páramo de Guaraque, M. López F. \& H. Rodríguez 22-01, 22821 (MERF, U); E1 Maciegal, cercanías de Mérida, M. López F. \& Ruiz T. 10560, 10565, 10582, 10657, 10673 (MERF); La Mucuy oberhalb Tabay, B. \& F. Oberwinkler \& J. Poelt, III. 1969 (hb. Poelt); Via La Mucuy-Laguna Verde, M. López F., T. Ahti \& P. M. Jörgensen 17978 (MERF); Păramo La Negra, M. López F. \& A. Morales-Mendez 29077 (MERF, U); La Pedregosa, W of Mérida, B. \& F. Oberwinkler \& J. Poelt, IIr.1969 (hb. Poelt); Monte Zerpa, cercanías de Mérida, M. López F. 16183 (MERF). TACHIRA: Via La Grita above hotel La Montana, M. E. Hale 42521, 42547 (US); Páramo de Tama, M. E. Hale \& M. López Figueiras 45094, 45241, 45369, 45407, 45416, 45439, 45646 (US); Vía Zumbador-Michelena, M. López F. \& M. Keogh 9506, 9523 (MERF); Alrededores de Betania, M. López F. \& L. Ruiz T. 10017, 10040, 10134 (MERF). TRUJILLO: Boconó-Mosquey, Alto de San Antonia, M. López F. \& M. Keogh 11673 (MERF), Bocono-Las Negritas, M. López F. \& M. Keogh 11553 (MERF); La Cava, entre la Hoya de Carruzo y páramo de Cendé, M. López F. 13241, 13242 (MERF).

Megalospora sulphurata Meyen var. nigricans (Mül1. Arg.) Sipm.

DISTRICTO FEDERAL: Caracas, Ernst, 1878 (G); E1 Avila, M. López F. 2532!, 25331, 25343 (MERF, U) (uz,AC), Sípman 10707 (U) (uz,AC). MERIDA: Páramo de Cendré, M. López F. 13034 (MERF); La Carbonera, vía Mérida-La Azulita, M. E. Hale 42073 (US), M. López F., K. Amman, V. Wirth \& B. Irlet 18111 (MERF), M. López F. 26760 (MERF) (uz,AC,DE?), Sipman 11017 (MERF, U) (uz,AC); La Gonzales-Păramo de las Coloradas, M. López F., M. Hale \& M. Keogh 13823 (MERF); Páramo de las Coloradas, M. López F. 25672 (MERF) (uz,-); Mucuy, M. E. Hale 43005 (US); Prado Verde, M. López F. 13520 (MERF). TRUJILlo: Carache-Las Penas, torre de TV, M. López F. 28611 (MERF) (uz,AC); Paramo de la Cristalina, M. López F. \& M. Keogh 11353 (MERF), 11439 (MERF) (on rock:); Finca E1 Mesedera, cerc. de Carache, M. López F. 16918 (MERF). TACHIRA: Alrededores de Betania, M. López F. \& Ruiz T. 10094, 10122, 10135 (MERF); Păramo de Tama, M. E. Hale \& M. López F. 45459 (US) (uz,-); Vía Zumbador-Michelena, M. López F. \& M. Keogh 9516 (MERF).

Megalospora tuberculosa (Fée) Sipm.

Moritz 43b, 64 (L) (uz,B). BOLIVAR: Cerro La Danta, J. Steyermark \& S. Nilsson 241 (UPS). DISTRICTO FEDERAL: Caracas, Ernst 41 (G,W) (uz,-); E1 Avila, Sipman 10744 (U, MERF) (uz,AC). FALCON: Sierra de San Luis, M. López F. \& H. H. van der Werff 21474 (MERF, U), Sipman 10886 (MERF, U) (uz,A). MERIDA: La Carbonera, vía Merida-La Azulita, M. E. Hale \& M. López F. 44111 (US) (uz, B), 44074 (US), M. López F. \& M. Keogh 9222 (MERF) (uz,B), 9245b (MERF), B, \& F. Oberwinkler \& J. Poelt, III.1969 (hb. Poelt) (uz,B); Páramo de las Coloradas, M. E. Hale \& M. López F. 44311 (US); Páramo de Garaque, M. López F. 22684. 22686 , 22707 (MERF); E1 Maciegal, cercanías de Mérida, M. López F. \& Ruiz T. 10653 (MERF); Páramo La Negra, M. López F. \& A. Morales-Mendez 29091 (MERF); Entre Tovar y el păramo de Guaraque, M. López F. 22633 (U); Monte Zerpa, M. López F. 22771 (MERF, U). MIRANDA: Guayabitos, V. Vareschi $12888 \mathrm{c}$ (US) (uz,ABC). TACHIRA: Alrededores de Betania, M. López F. \& L. Ruiz T. 10105 (MERF); Páramo de Tama, M. E. Hale \& M. López F. 45653 (US); Páramo E1 Zumbador, M. López F. \& M. Keogh 9383 (MERF). TRUJILLO: Carache-Las Penas, entre Agua de Obispo y torre de TV, M. López F. 28495 (MERF) (uz, B), 28507 (MERF) (uz, B), 28613 (MERF) (uz, B) 


\section{VIETNAM}

Megalospora tuberculosa (Fée) Sipm.

Mnt. Bavi, Tonkin, Balansa, ex hb. Boissier (W) (pz,AC).

\section{ZAIRE}

Catinaria versicolor (Fée) Sipm.

Massif du Kahuzi, versant so du mont au piste du Kahuzi, Lambinon 71-1206 (LG)

Megalospora pruinata (Mïl1. Arg.) Sipm. ssp. pruinata

Nyiragongo, Lambinon 72-569 (LG) (pz,AC).

Megalospora tuberculosa (FÉe) Sipm.

Massif du Kahuzi, Lambinon 71-1225 (LG) (uz,AC). 
Acknowledgement

In the first place I wish to express my sincere gratitude to my promotor, Prof. Dr. A. L. Stoffers, and to my teacher in the study of Cryptogams, Dr. S. R. Gradstein. My promotor generously provided all facilities needed and the freedom to develop the investigation in the desired direction. Dr. Gradstein has been my mentor in the study of bryophytes and lichens since a long time. During the present work he supported me in many ways, such as by arranging facilities for field work in the neotropics, New Guinea and New Zealand, and by extensive, constructive criticism of the manuscript.

I gratefully acknowledge the kind support by many collegues abroad. Mr. P. W. James (London) placed at my disposal facilities at the British Museum (Natural History) and provided useful criticism of the manuscript. Dr. M. E. Hale (Washington) helped me in many ways and suggested, for instance, the subject of this study. Prof. Dr. A. Henssen and Dr. G. Vobis (Marburg) generously made available research facilities and advice in the field of apothecium ontogeny. Prof. Dr. E. Tschermak-Woesz (Vienna) cultivated and studied the mycobiont of the Megalosporaceae. Moreover, I am greatly indebted to the curators of the many herbaria who kindly placed the requested specimens, and sometimes much useful unrequested information, at my disposal. I furthermore thank Dr. K. Kalb (Neumark) for very useful field work support and Mr. J. Bartlett (Pakuranga) for searching and sending so many interesting collections. Mrs. Dr. H. A. Masselink-Beltman (Doorwerth) kindly provided useful criticism of the manuscript.

The technical and scientific staff of the Institute of Systematic. Botany of the State University of Utrecht kindly placed all desired information and aid at my disposal. 
PLATES 

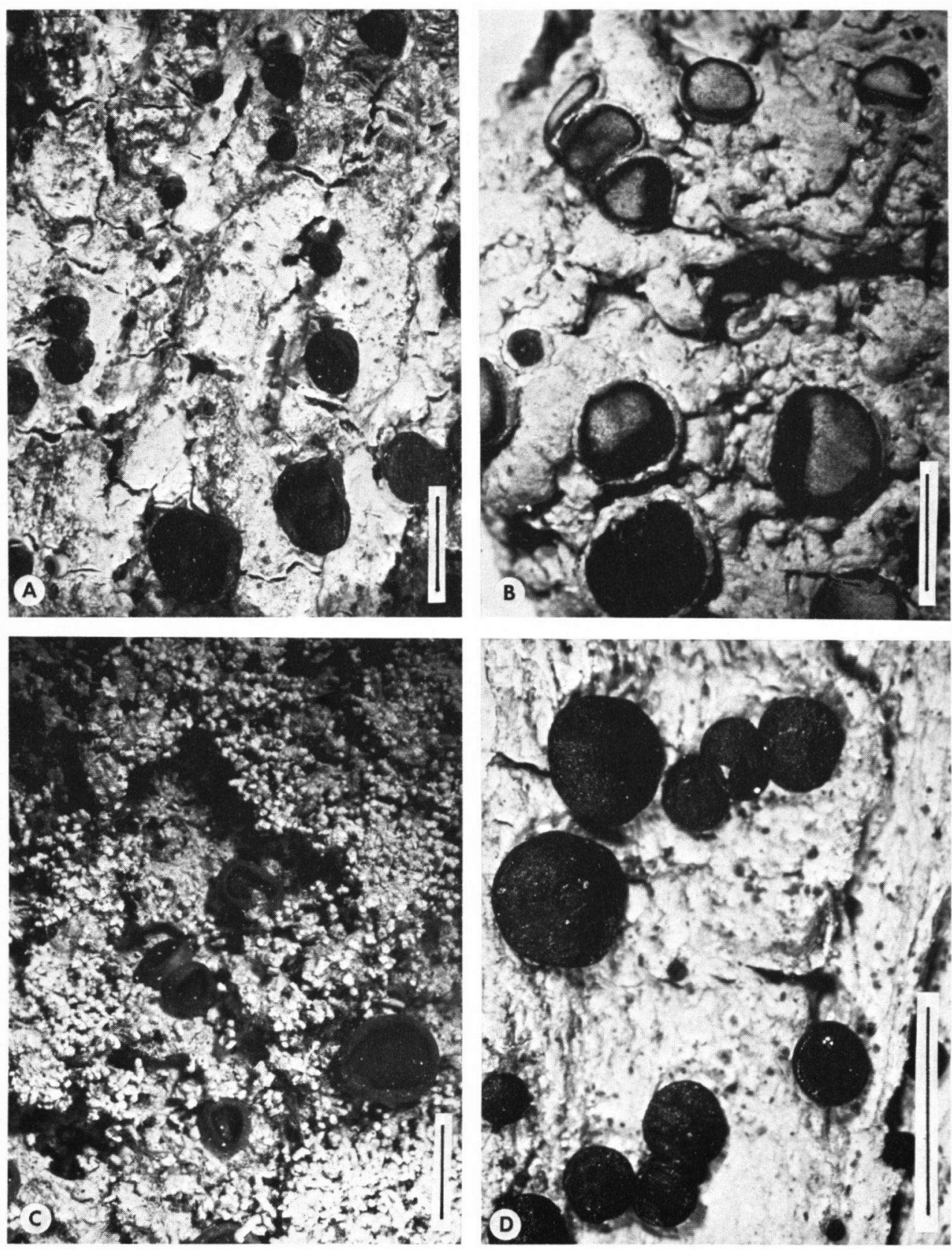

PLATE 1. Megalospora, habitus. A. Megalospora hillii (Hill 11654); B. Megalospora melanodermia (Morris, 21.V.1957); C. Megalospora sulphurata, isidiate specimen (van Ooststroom 14462); D. Megalospora atrombicans ssp. sendaiensis (Yasuda 108). Rule $=2 \mathrm{~mm}$. 

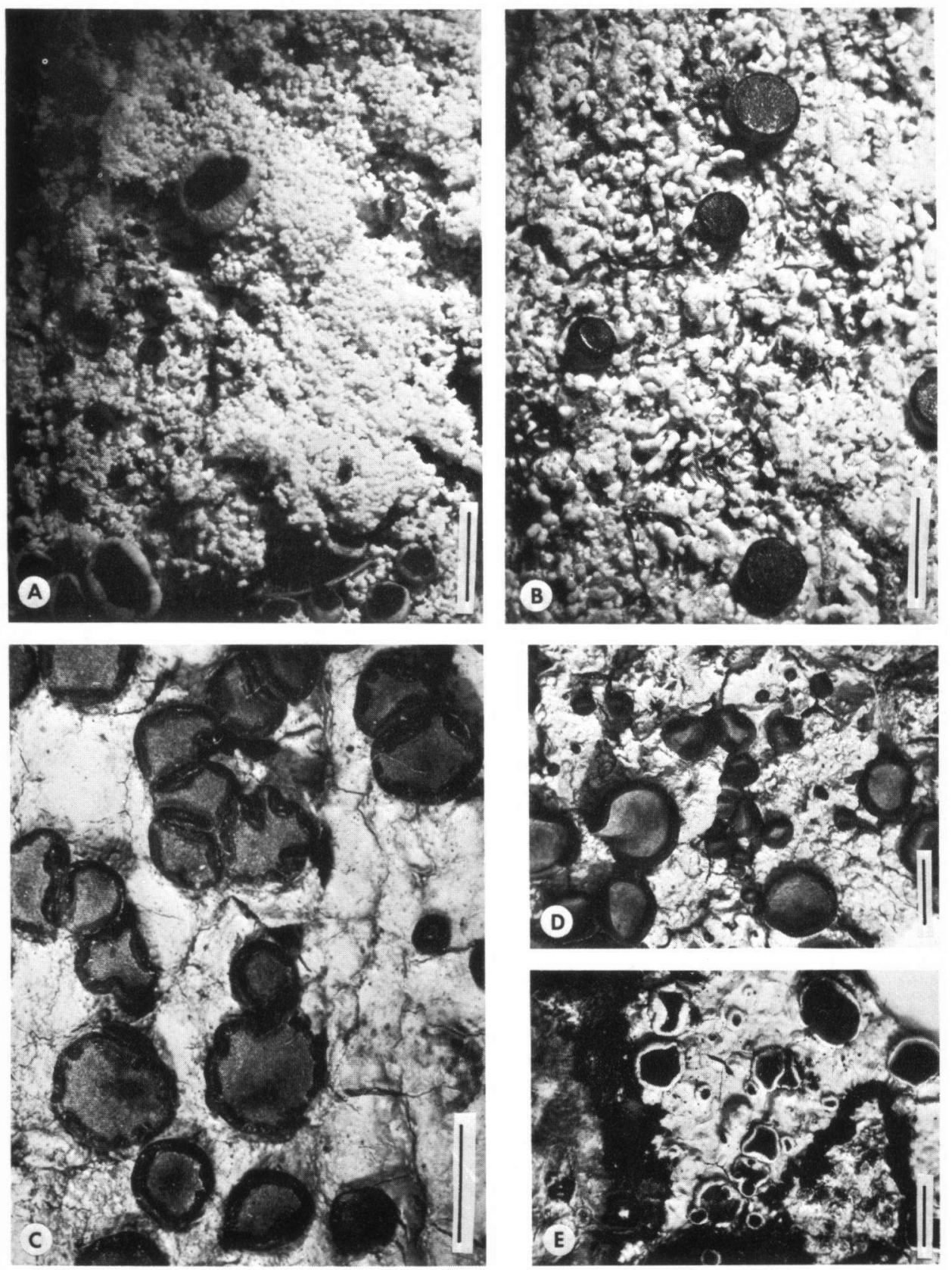

PLATE 2. Megalosporaceae and Lecania, habitus. A. Megalospora granuZans, sorediate specimen (Sipman 15872B); B. Megalospora halei, isidiate specimen (Sipman 15967); C. Megaloblastenia marginiflexa var. marginiflexa (Knight 85, H-Nyl. 18192); D. Megalospora gompholoma ssp. gompholoma; E. Lecania sulphureofusca, with black prothallus (Sipman 11901). Rule = $2 \mathrm{~mm}$. 

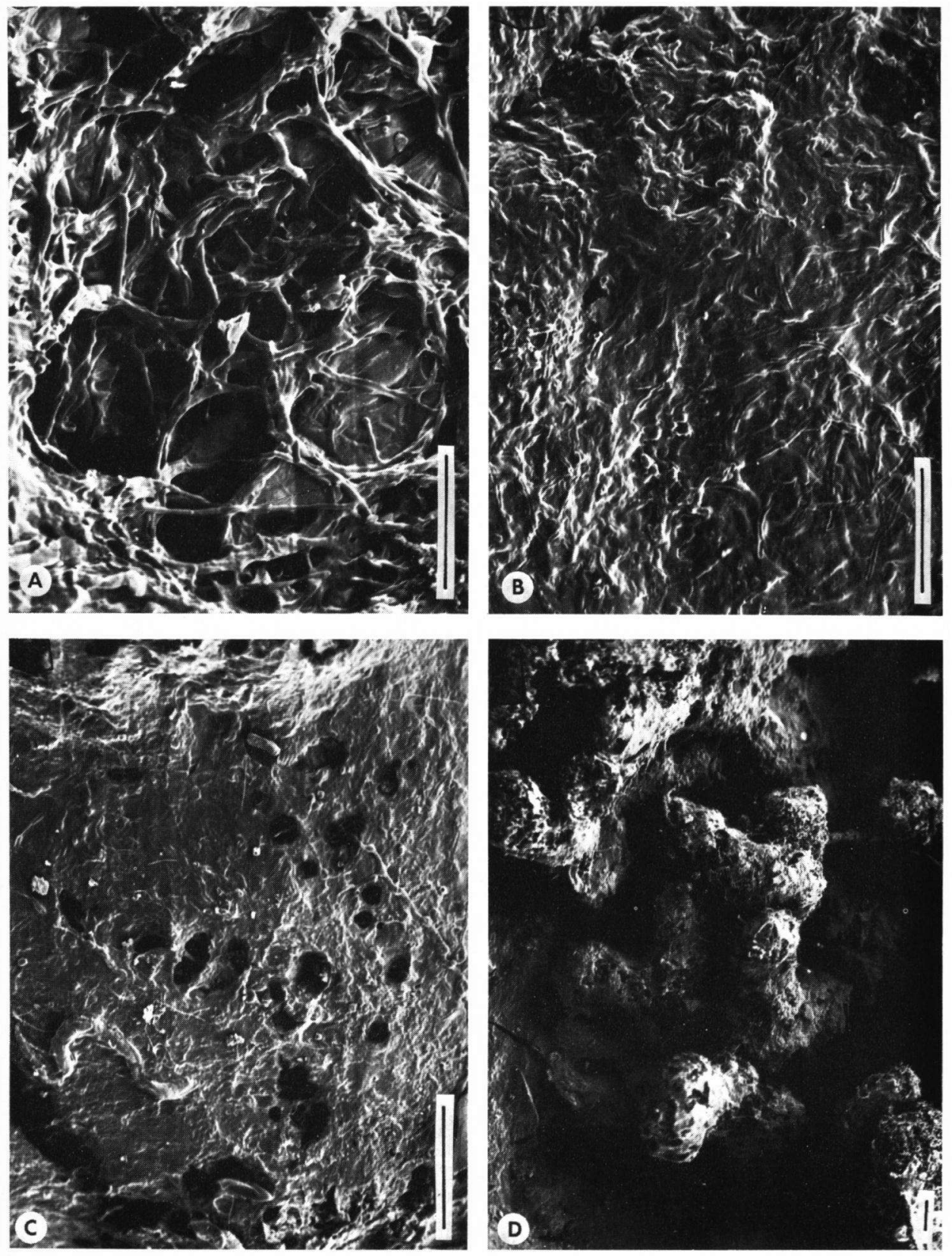

PLATE 3. TEM microphotographs. A. Catinaria versicolor, thallus surface (Sipman 11025); B. Megalospora sulphurata, thallus surface (Sipman 12910); C. Megalospora sulphurata, porose thallus surface (Rechinger 3323); D. Megalospora sulphurata, isidia (Groenhart 4035). Rule $=40 \mu \mathrm{m}$. 

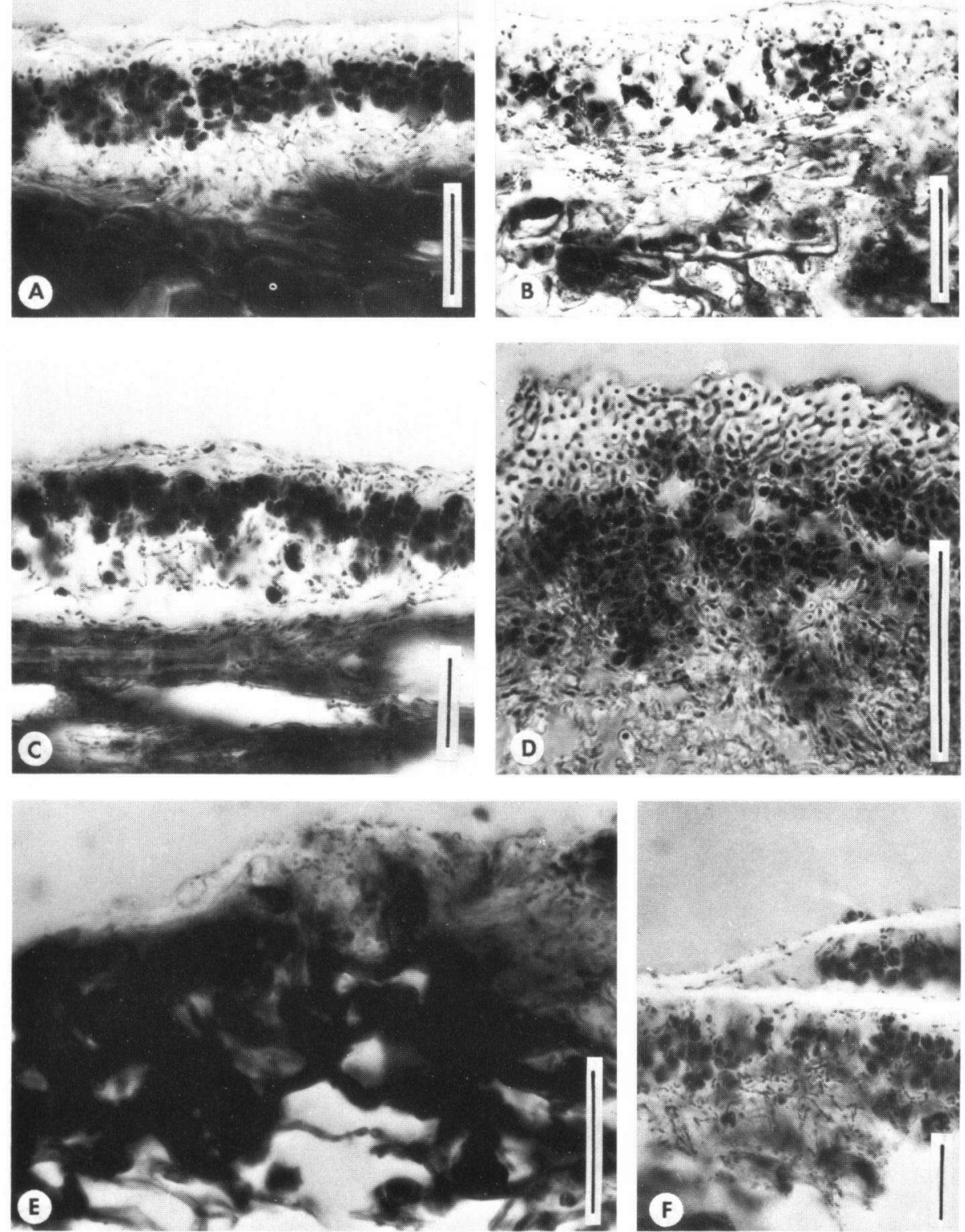

PLATE 4. Thallus sections. A. Megaloblastenia marginiflexa var. marginiflexa (Tucker 20264); B. MegaZospora gompholoma ssp. gompholoma (Knight, H-Nyl, p.m. 4537); C. Megazospora sulphurata (Sipman 13726); D. Catinaria versicolor (Lópe: 22801); E. Leconia sulphureofusca, thallus and prothallus (Sipman 11901); F. Leconia sulphureofusca, thallus with two cortical layers (Sipman 11901). Rule $=40 \mu \mathrm{m}$. 

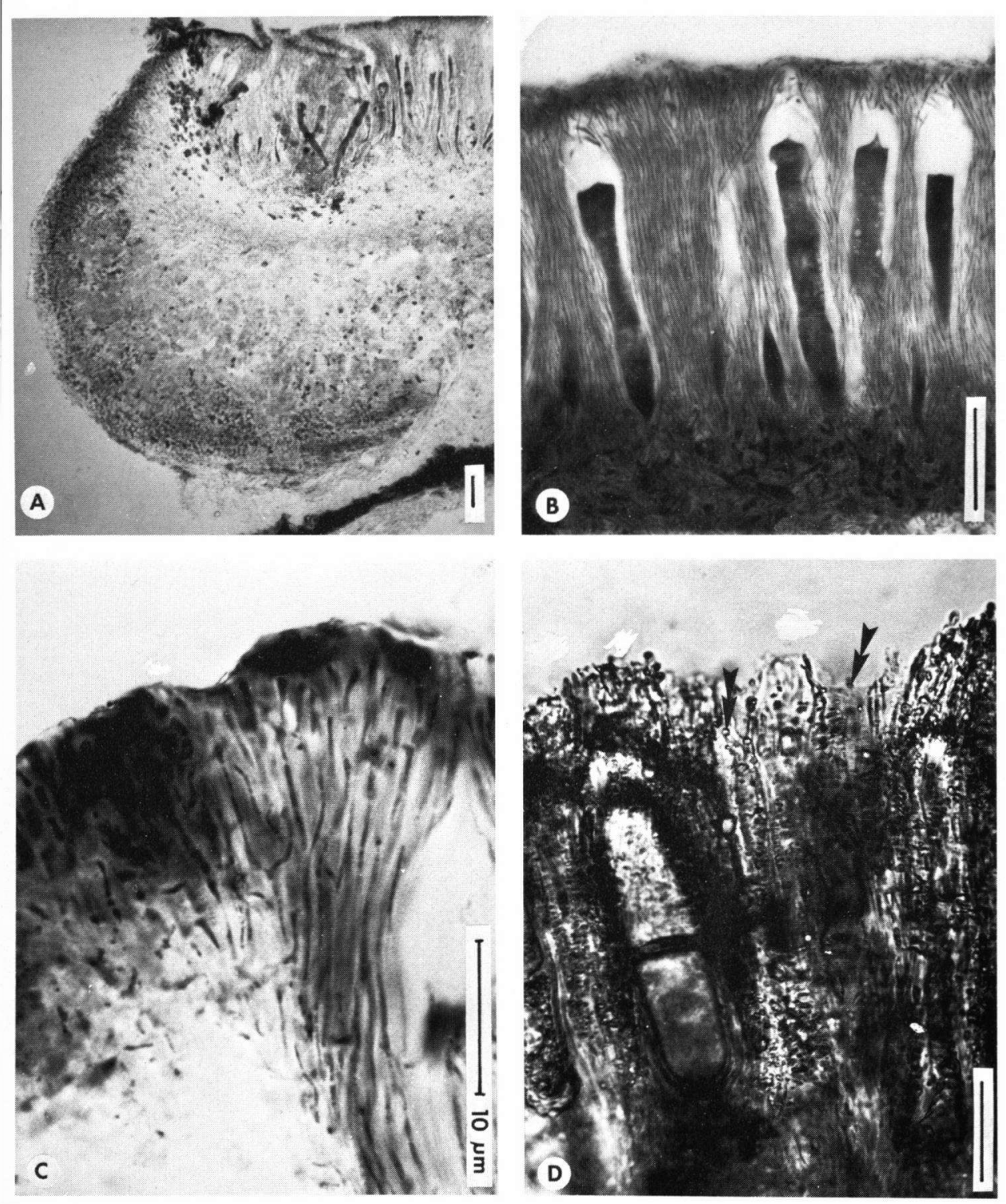

PLATE 5. Megalospora, structure of the apothecium. A. Megalospora sulphurata, survey (Sipman 13726); B. Megalospora sulphurata, hymenium (Sipman 12938); C. Megalospora sulphurata, parathecial crown (Sipman 13088); D. Megalospora gompholoma ssp. gompholoma, hymenium, water-mounted (arrows indicate oil-droplets) (Zotov s.n.). Rule $=40 \mu \mathrm{m}$, unless otherwise indicated. 

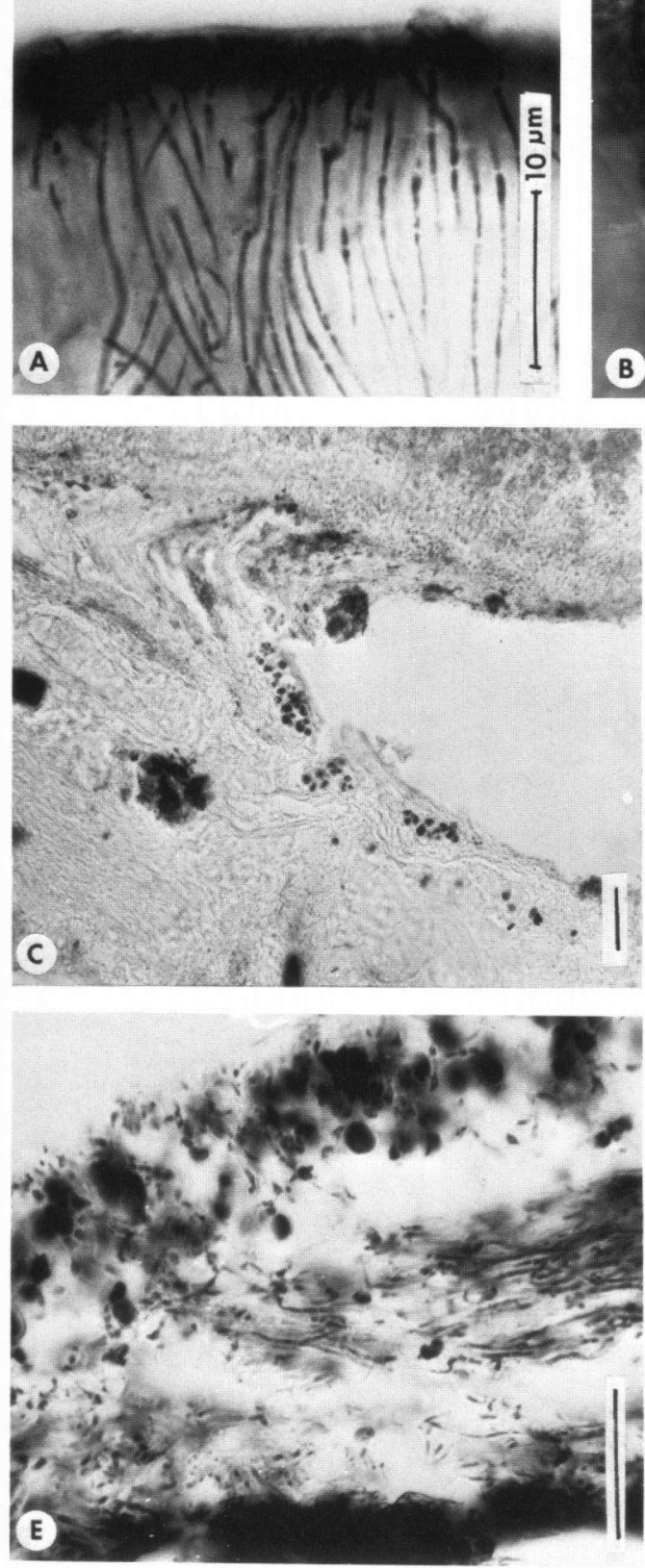

B
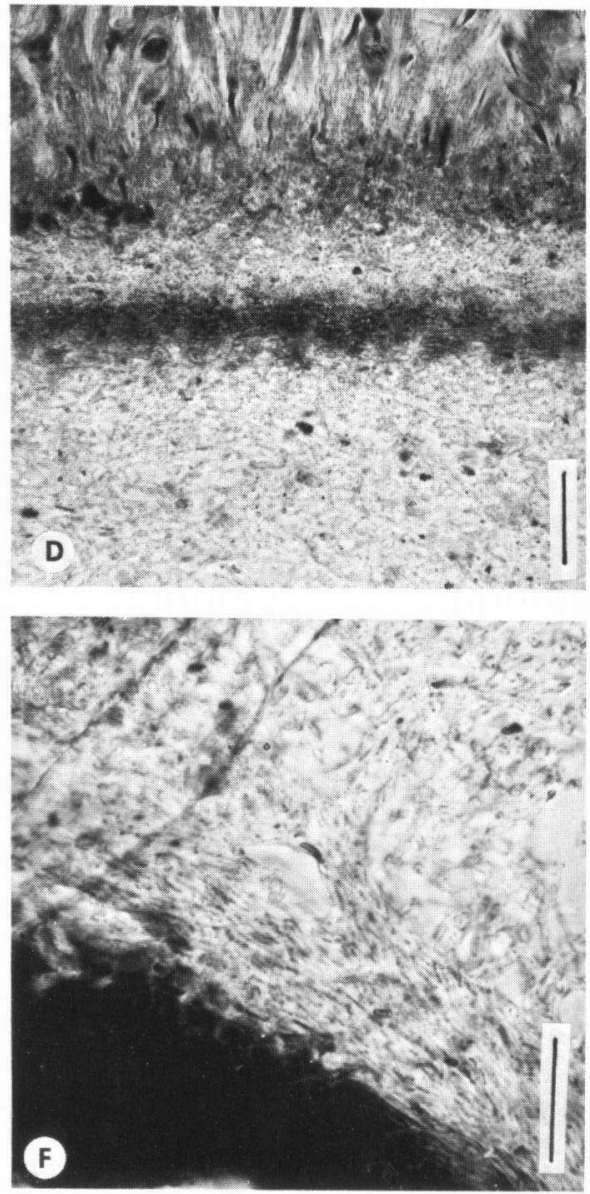

PLATE 6. Megalospora, structure of the apothecium, continued. A. Megalospora sulphurata, epithecium (Sipman 13088); B. Megalospora coccodes ssp. nigricans, epithecium with crystals of calcium oxalate (arrow) (Sipman 15708); C. Megalospora sulphurata, attachment layer (Sipman 12973); D. Megalospora sulphurata, sequence of layers from hymenium to medullary excipulum (Sipman 13726); E.

Megalospora sulphurata, thallus section with anchorage bundle (Sipman 13088); F. Megalospora sulphurata, transition from medullary excipulum to anchorage bundle $($ Sipman 13726). Rule $=40 \mu \mathrm{m}$. 

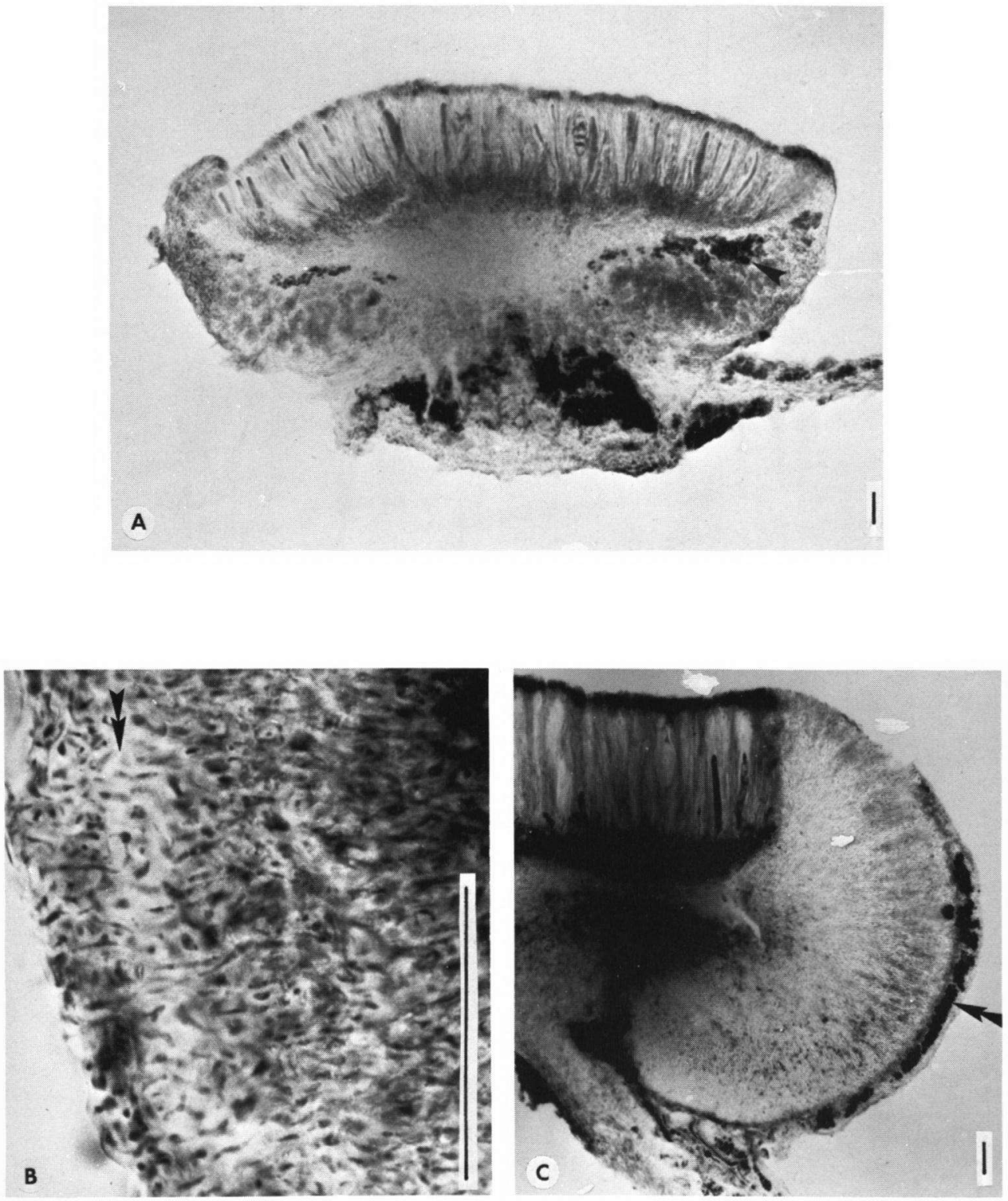

PlATE 7. Megalospora, structure of the apothecium, continued. A. Megalospora australiensis, view of apothecium with algal cells (arrow) in the medullary excipulum (Hartmann L 41); B. Megalospora sulphurata, transition from ectal excipulum into attachment layer (arrow indicates outer border of ectal excipulum) (Sipman 13088); C. Megalospora coccodes ssp. nigricans, view of apothecium with extended attachment layer containing algal cells (arrow) (Sipman 15708). Rule $=40 \mu \mathrm{m}$. 

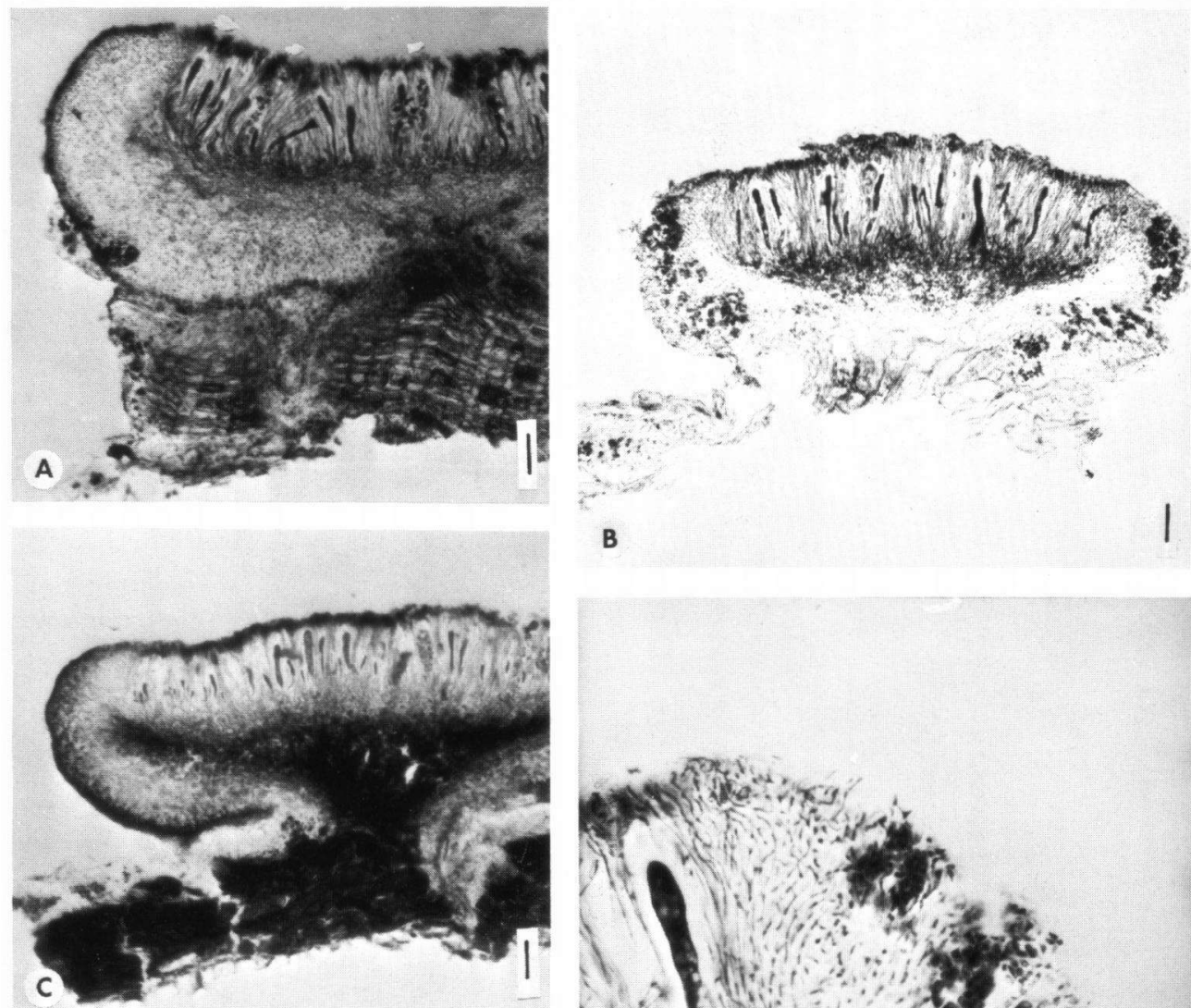

B
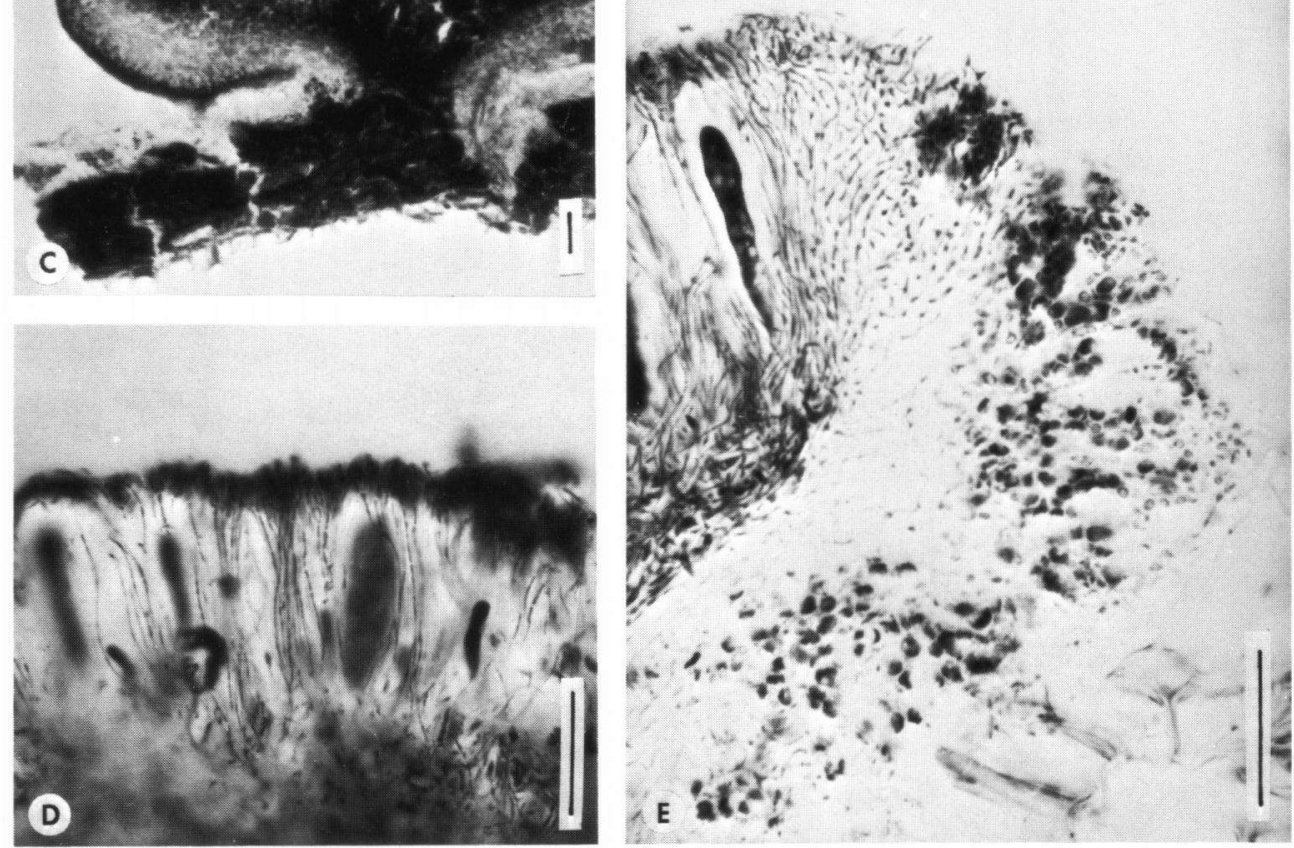

PLATE 8. Megaloblastenia marginiflexa and Lecania sulphureofusca, structure of the apothecium. A. Megaloblastenia marginiflexa var. dimota, view of apothecium with pale subhypothecium (Puiggari 1522); B. Lecania sulphureofusca, of apothecium (Sipman 10368); C. Megaloblastenia marginiflexa var. marginiflexa, view of apothecium with dark, conical subhypothecium (Tucker 20264); D. Megaloblastenia marginiflexa var. marginiflexa, hymenium (Tucker 20264); E. Lecconia sulphureofusca, margin with well developed parathecium and thalloid amphithecium (Sipman 10368). Rule $=40 \mu \mathrm{m}$. 

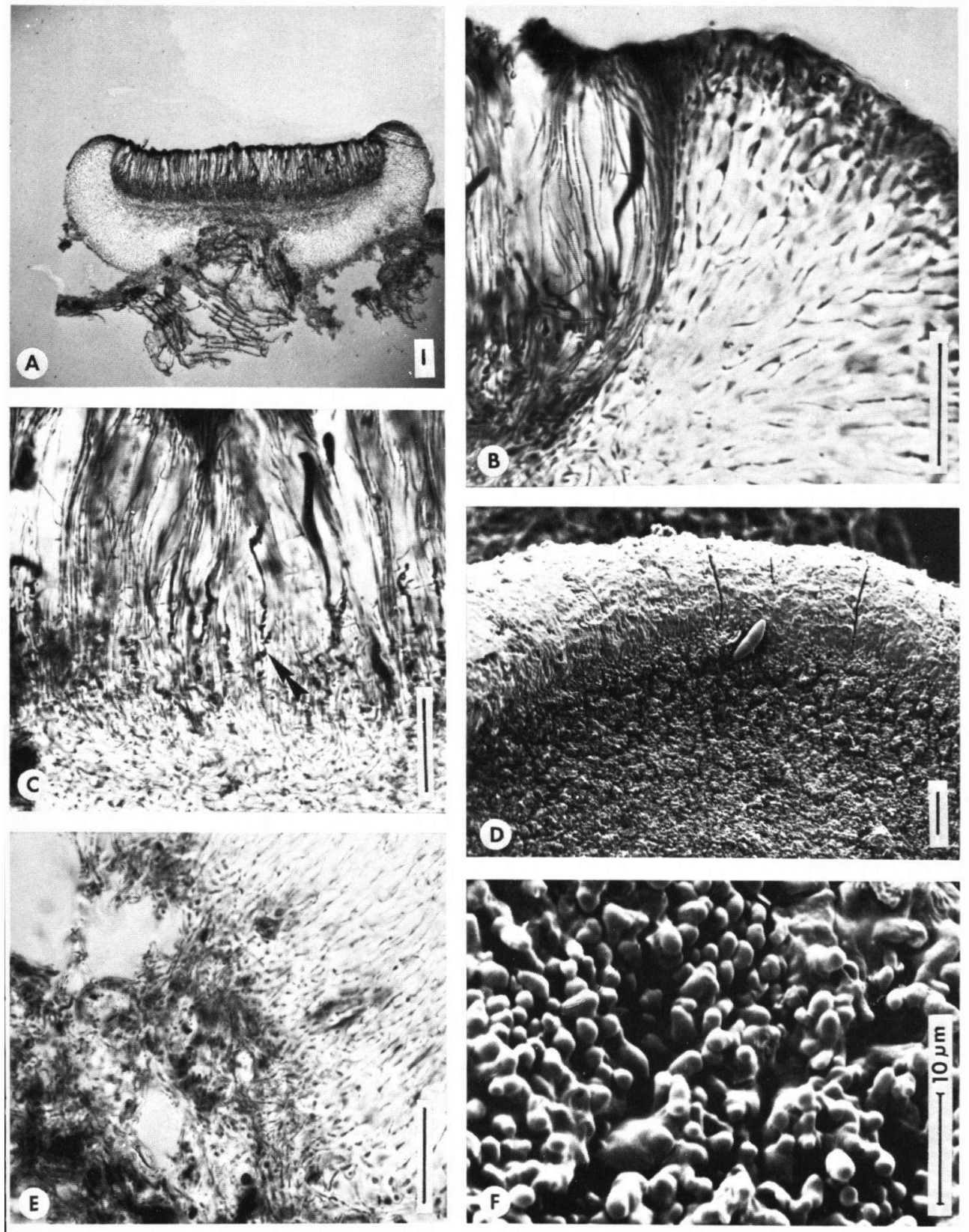

PLATE 9. Catinaria versicolor, structure of the apothecium. A. view (Lrpez

22801 ); B. parathecial crown with adjacent hymenium and excipulum (López 22801); C. view of layers from epithecium to subhypothecium, with ascending ascogenous hyphae (arrow) (López 22801); D. TEM photograph of surface of apothecial margin and disc with ascospore (Sipman 11025); E. ectal excipulum with attachment layer forming anchorage bundle which penetrates into the thallus (López 22801); F. detail of hymenial surface of $D$. Rule $=40 \mu m$ unless otherwise indicated. 

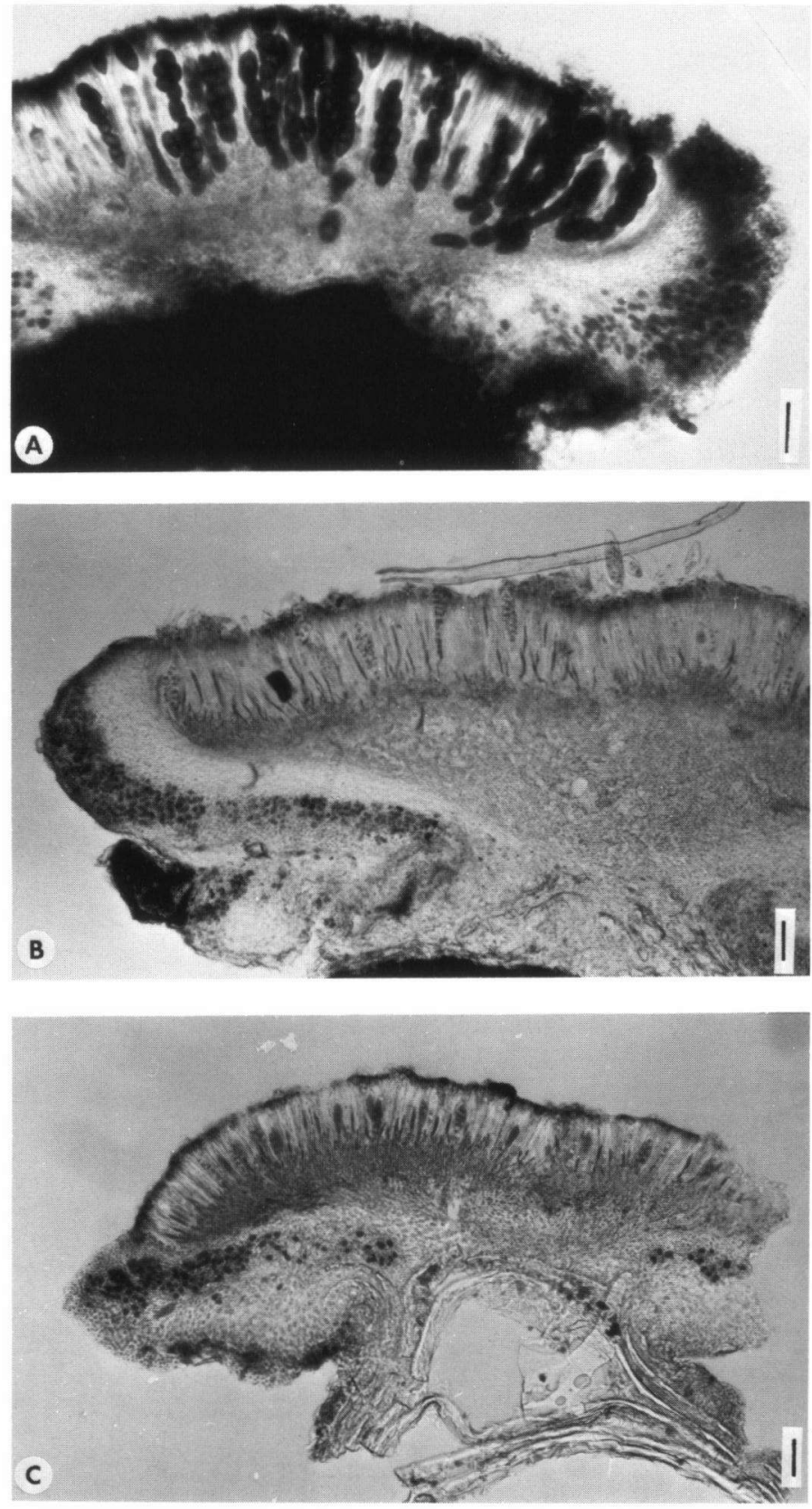

PLATE 10. Structure of the apothecium in some Lecanorales. A. Rinodina miaraea (Stud. Bio1. 75-554); B. Caloplaca quadrilocularis (Sipman 13075); C. Caloplaca cerina (Stud. Bio1. 73-447). Rule $=40 \mu \mathrm{m}$. 

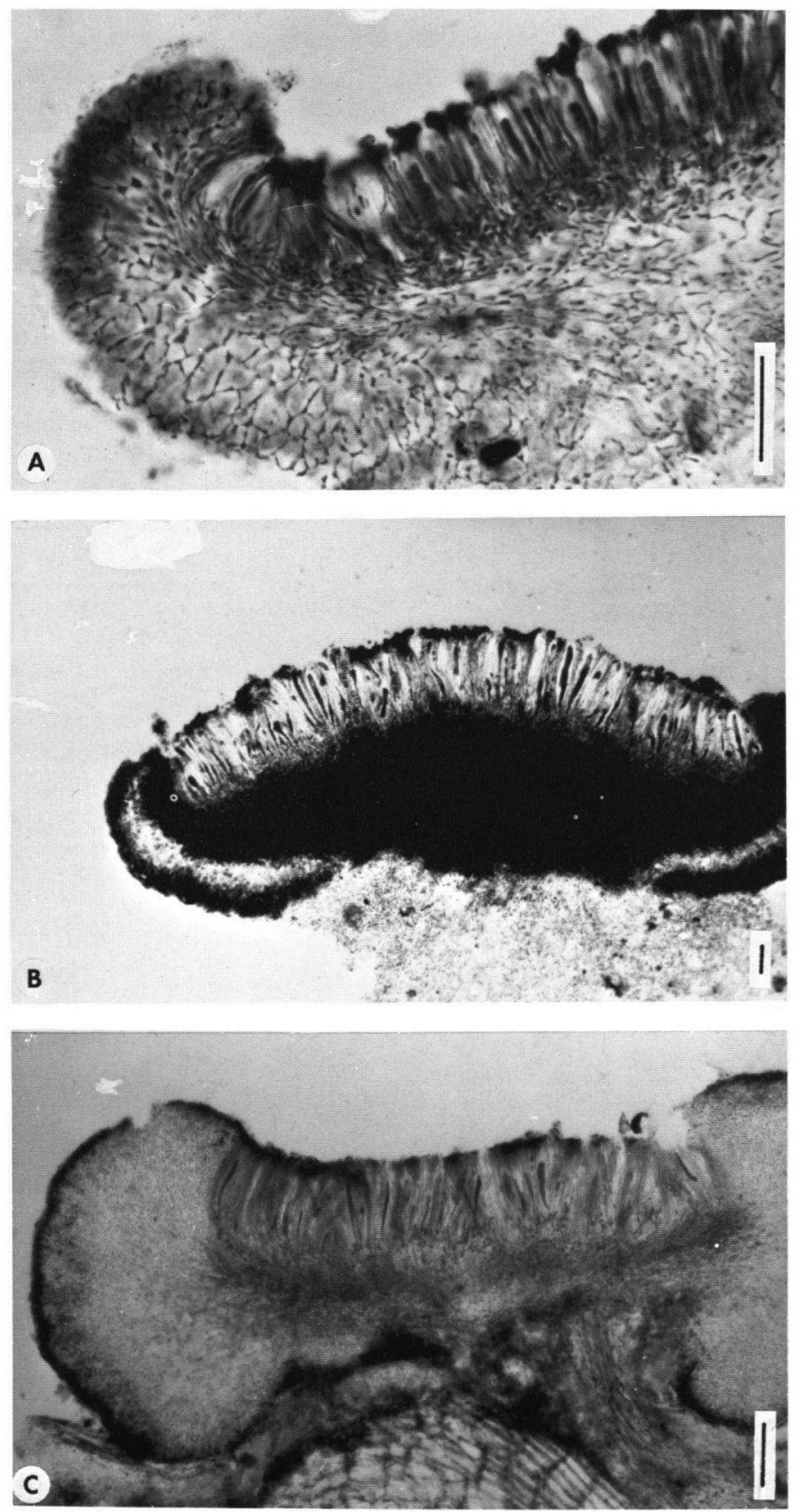

PLATE 11. Structure of the apothecium in some Lecanorales, continued. A. Cliostomum griffithii (Henssen 17483 f); B. Catinaria grossa (ZW 987); C. Letrouitia domingensis (Sipman 12314). Rule $=40 \mu \mathrm{m}$. 

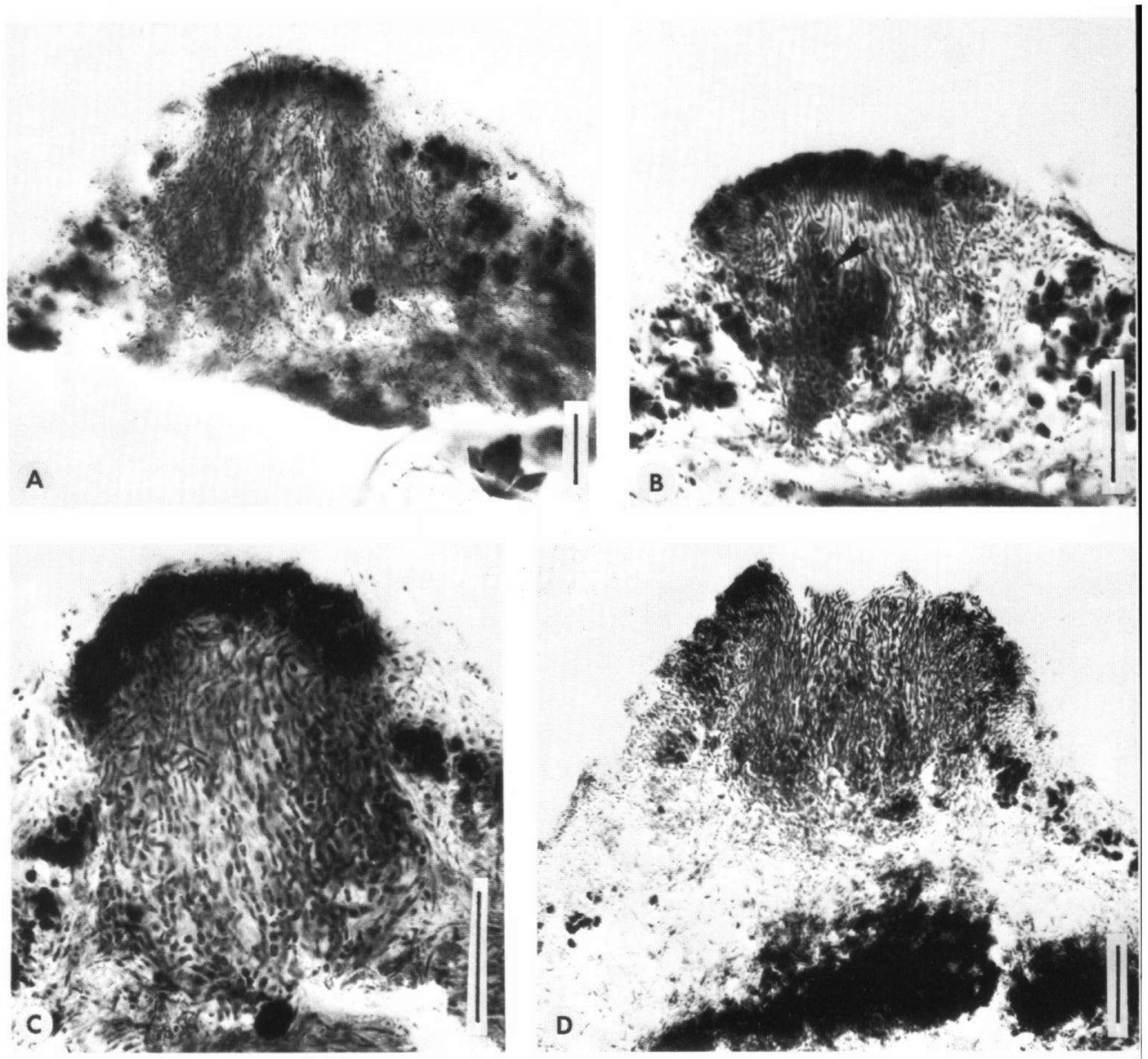

PLATE 12. Megalospora sulphurata, ontogeny of the apothecium. A. young primary corpus stage (Sipman 12938); B. young primary corpus stage with ascogonia (arrow) (Sipman 12929); C. advanced primary corpus stage (Sipman 12938); D. youngest apothecium stage (Sipman 12938). Rule $=40 \mu \mathrm{m}$. 

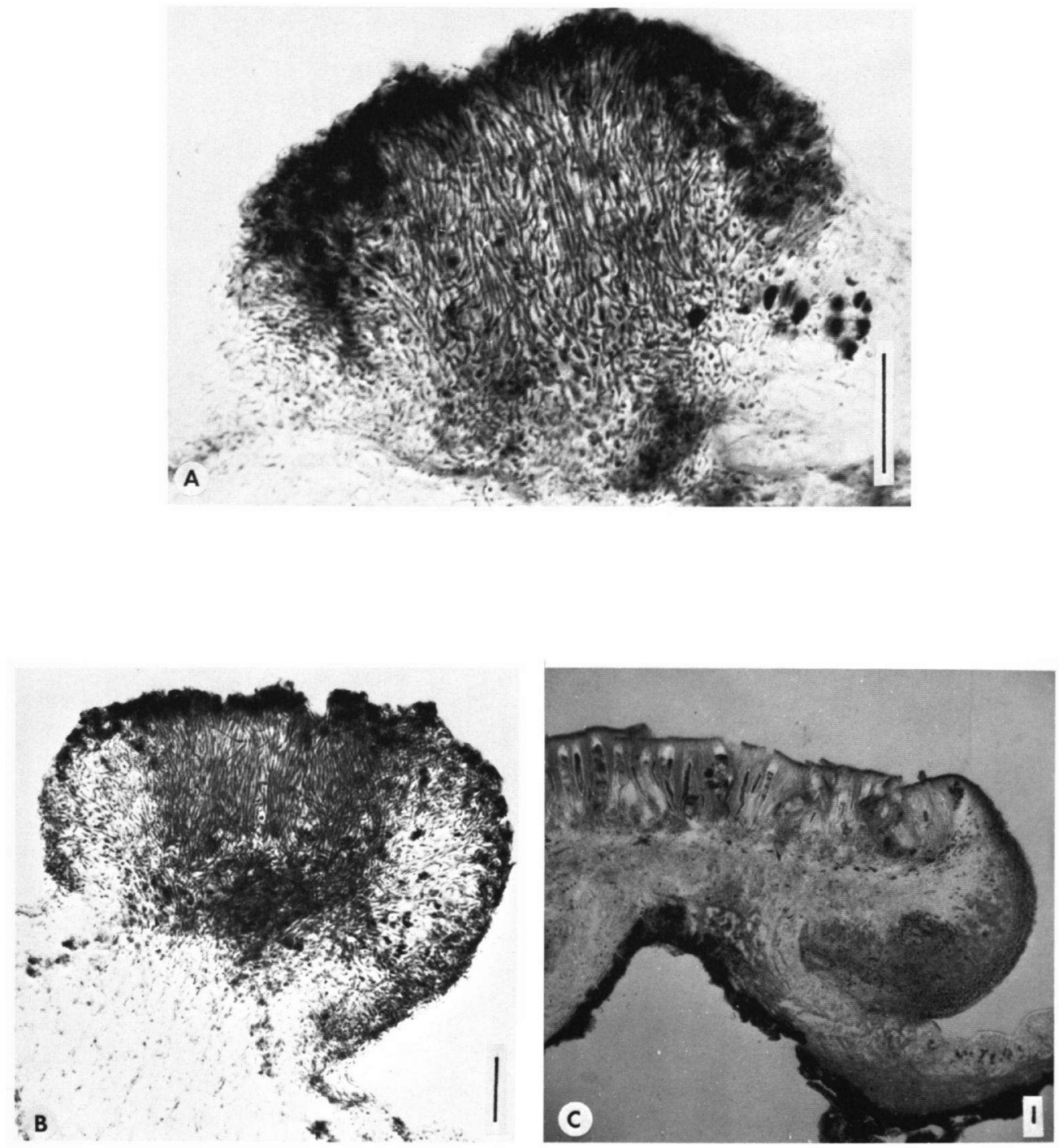

PLATE 13. Megalospora sulphurata, development of the apothecium. A. youngest apothecium stage (Sipman 12943); B. young apothecium (Sipman 12938); C. old apothecium (Sipman 13726). Rule $=40 \mu \mathrm{m}$. 

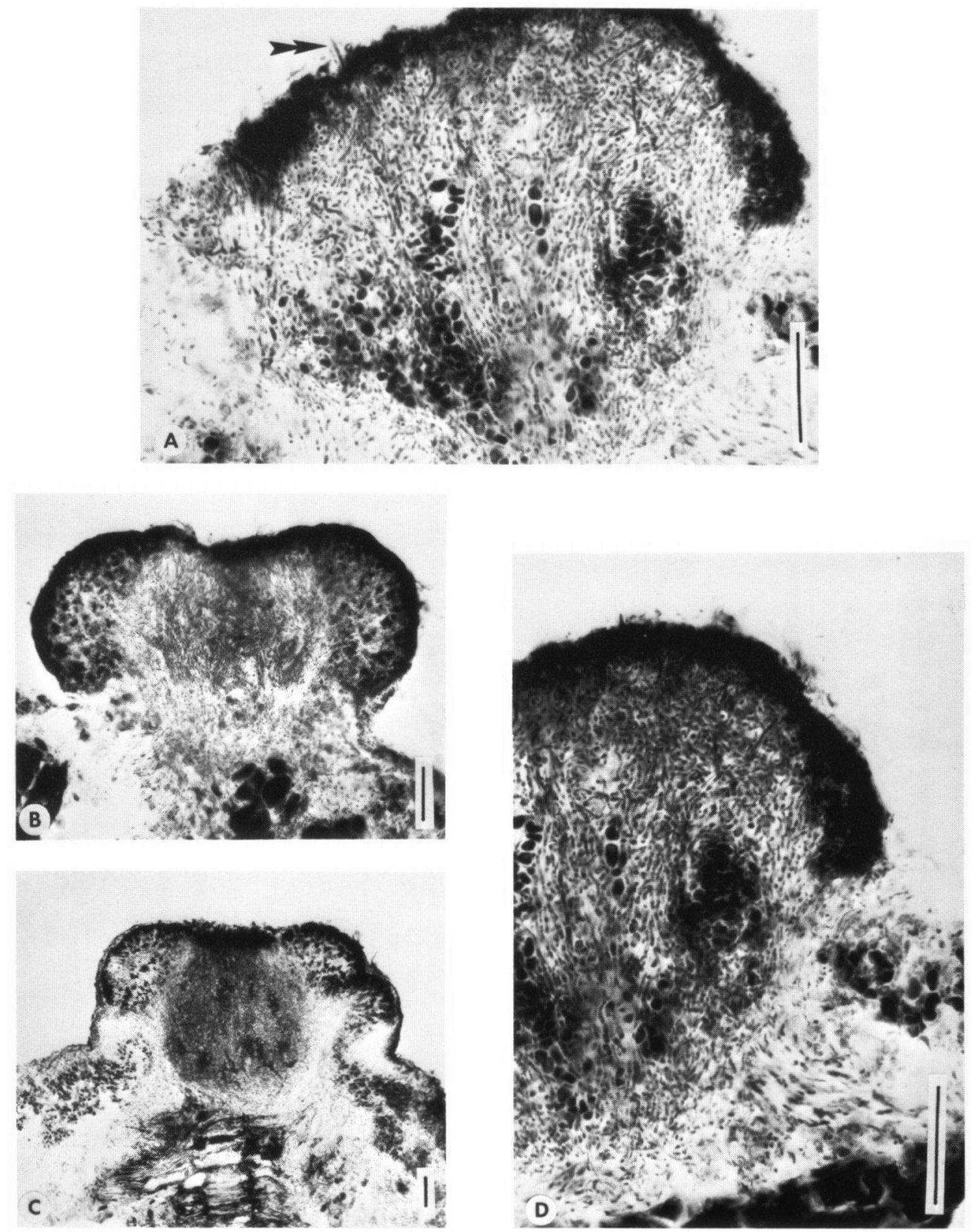

PLATE 14. Megalospora gompholoma ssp. gompholoma, ontogeny of the apothecium. A. primary corpus stage (arrow indicates trichogyne) (H-Nyl. p.m. 4537); B. primary corpus stage with excipulum development (H-Ny1. p.m. 4537); C. primary corpus stage with repeated excipulum development (Knight s.n.); D. detail of A, with bundles of hyphae directed towards the parathecial crown. Rule $=40 \mu \mathrm{m}$. 

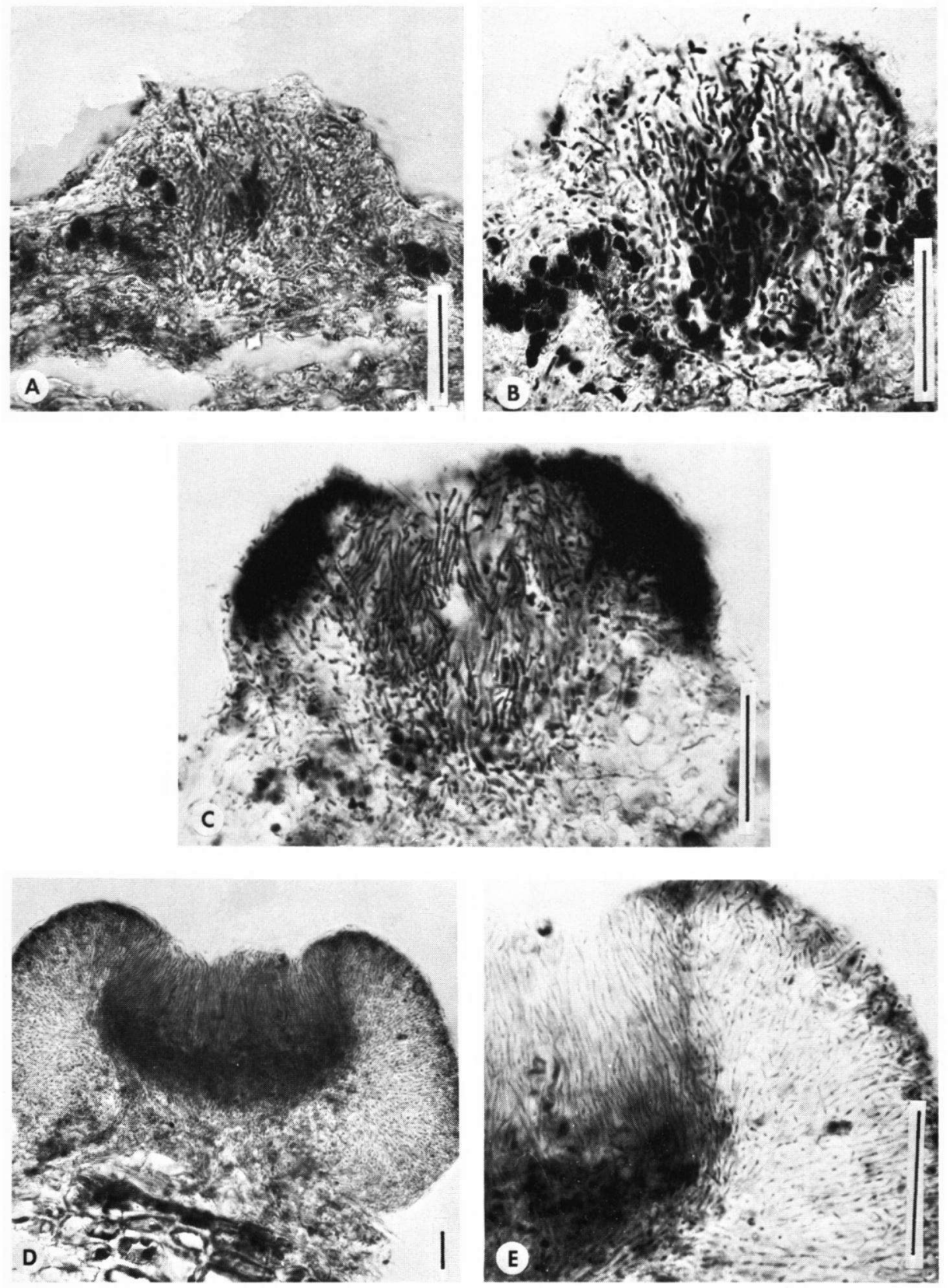

PLATE 15. Megalospora tuberculosa, ontogeny and development of the apothecium. A. small primary corpus stage (Sipman 12727); B. primary corpus stage (Sipman 12727); C. youngest apothecium stage (Sipman 12727); D. young apothecium (Sipman 12727); E. detail of $D$ showing parathecial crown. Rule $=40 \mu \mathrm{m}$. 

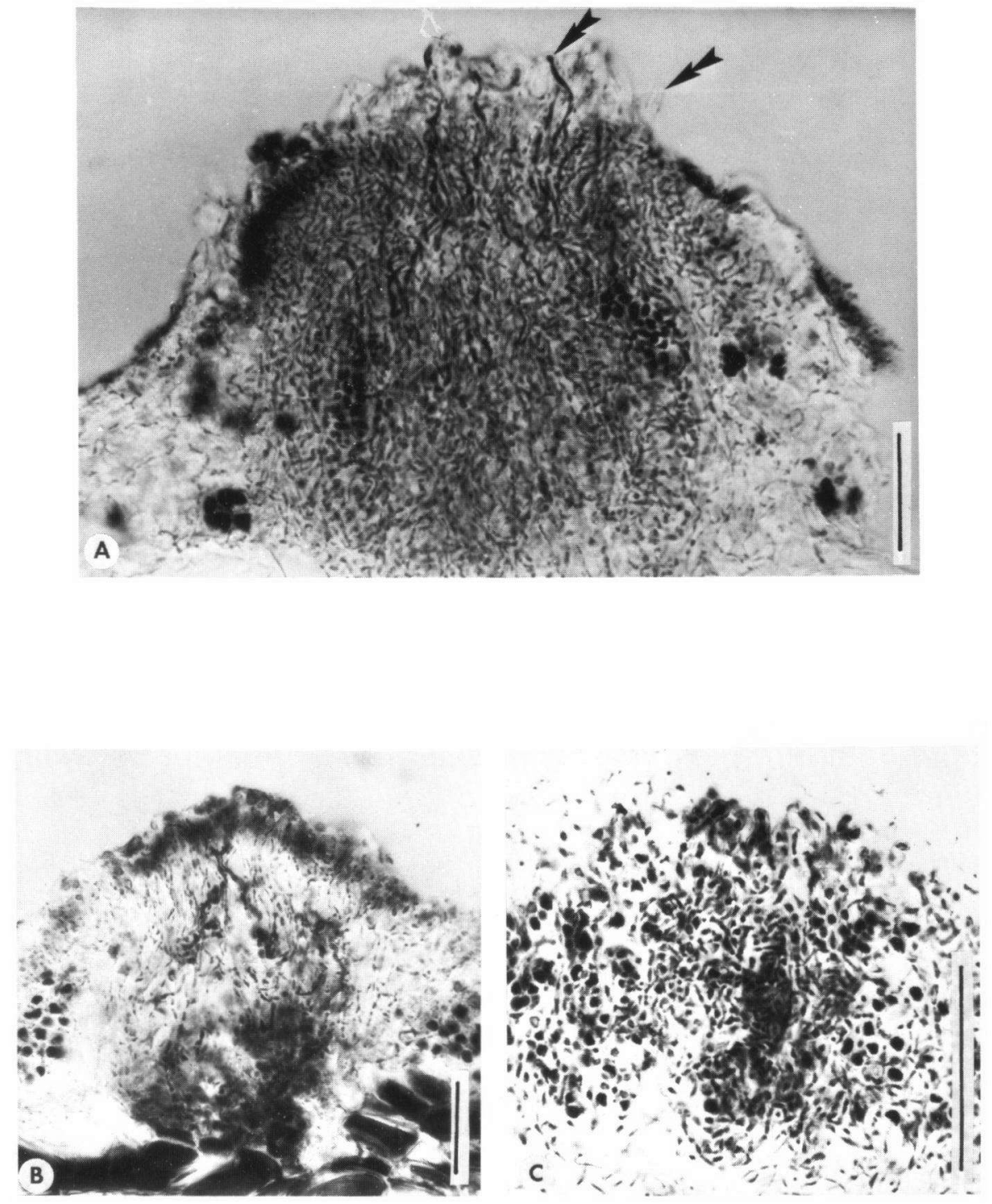

PLATE 16. Megaloblastenia marginiflexa and Catinaria versicolor, ontogeny of the apothecium. A. Megaloblastenia marginiflexa var. dimota, primary corpus stage with many trichogynes (arrow) (Sipman 13035); B. Megalospora marginiflexa var. marginiflexa, primary corpus stage (Tucker 20264); C. Catinaria versicolor, primordium stage? (López 21542). Rule $=40 \mu \mathrm{m}$. 

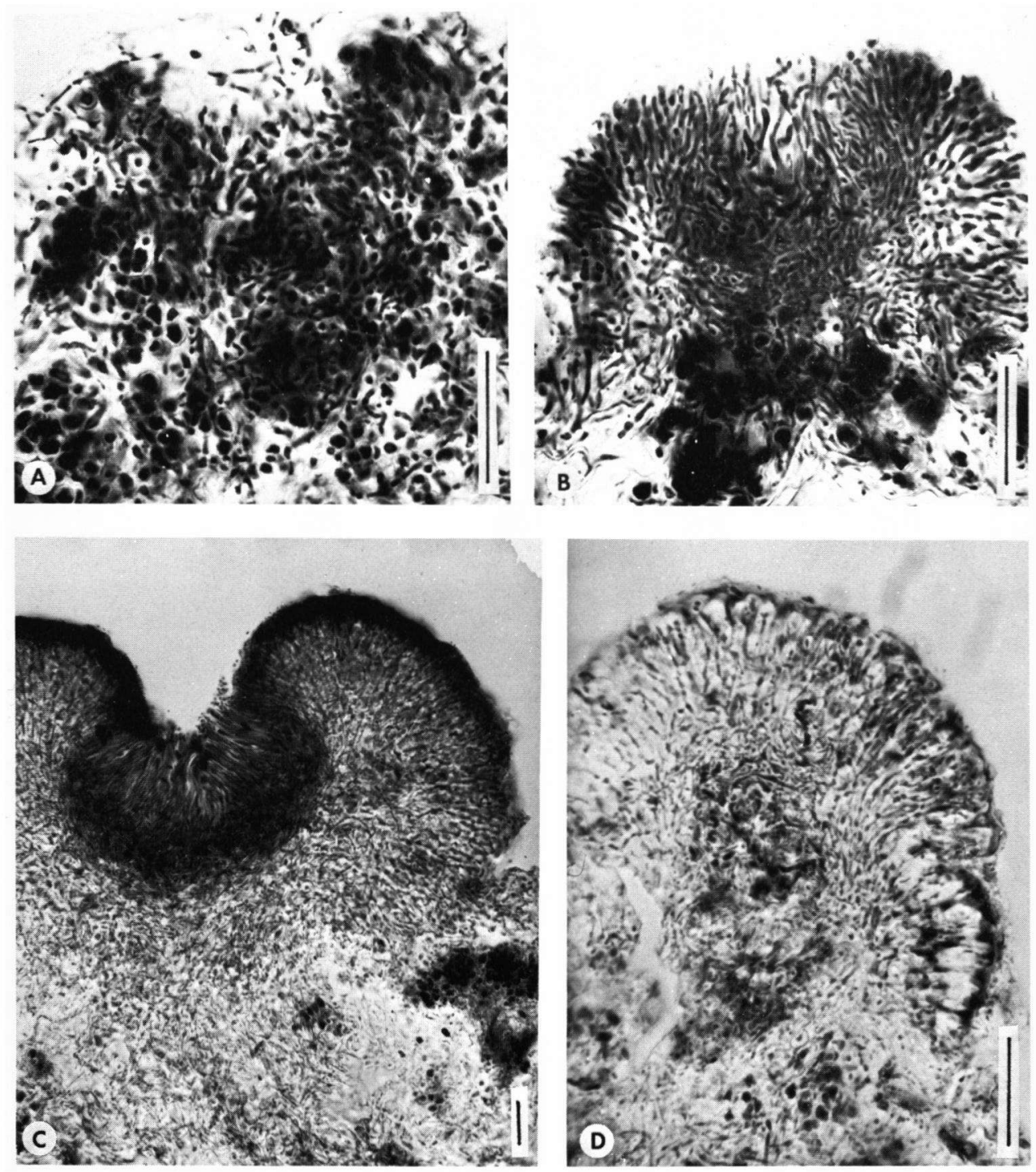

PLATE 17. Catinaria versicolor, ontogeny and development of the apothecium. A. primordium stage? (López 21542); B. youngest apothecium stage (López 22801); C. young apothecium (López 21542); D. abnormal stage (Hale 44002). Rule $=40 \mu \mathrm{m}$. 

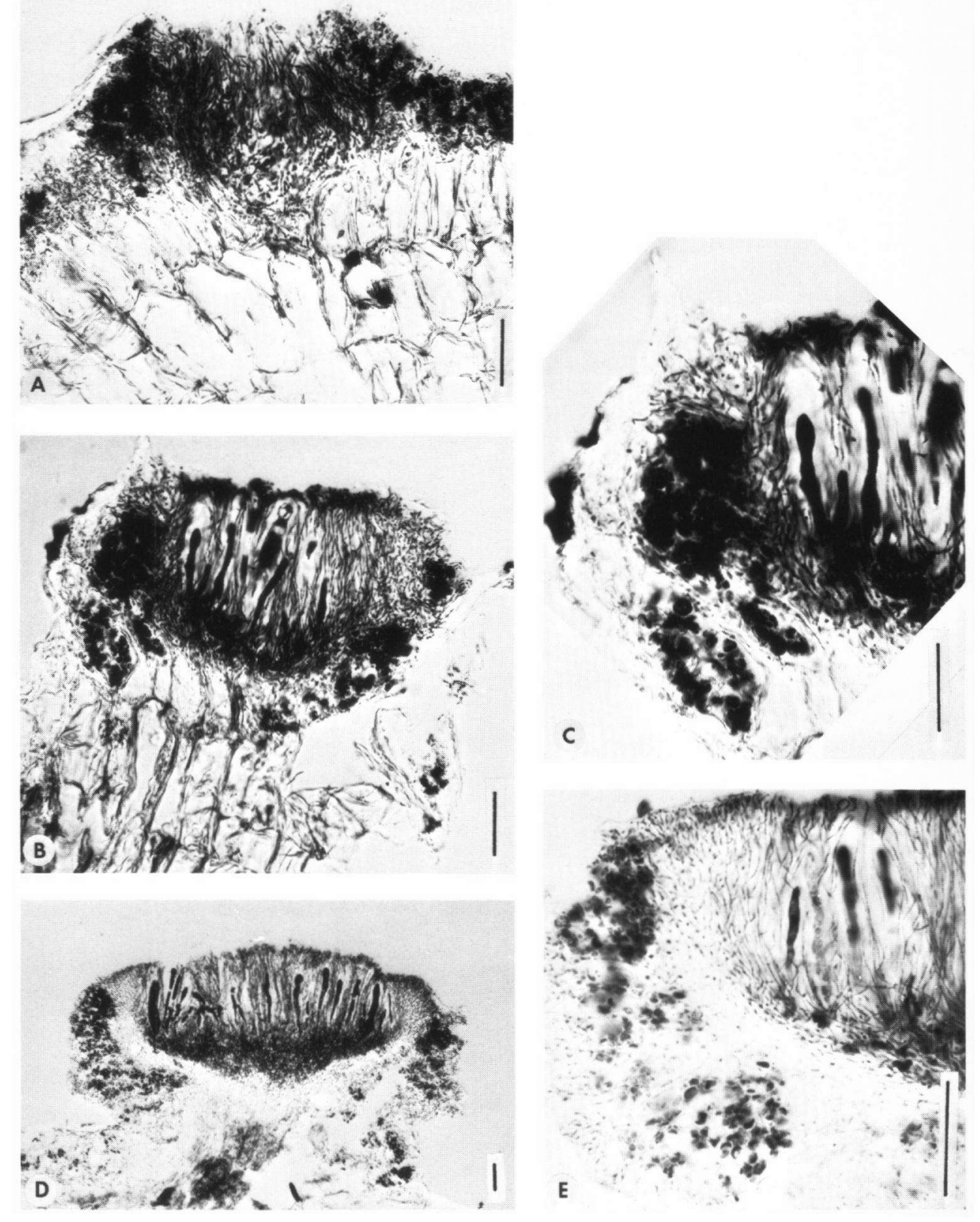

PLATE 18. Lecania sutphureofusca, development of the apothecium. A. Youngest apothecium stage (Sipman 10368); B. young apothecium (Sipman 10368); C. detail of $B$ showing mass of multiplying algae next to the parathecial crown; $D$. young apothecium (Sipman 10368); E. detail of D, showing well developed parathecium. Rule $=40 \mu \mathrm{m}$. 

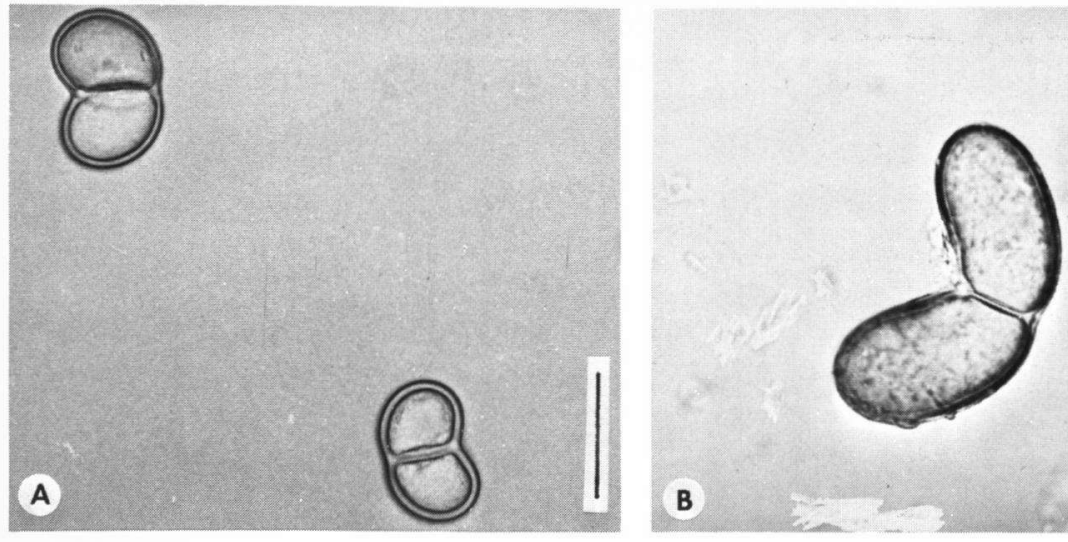

B
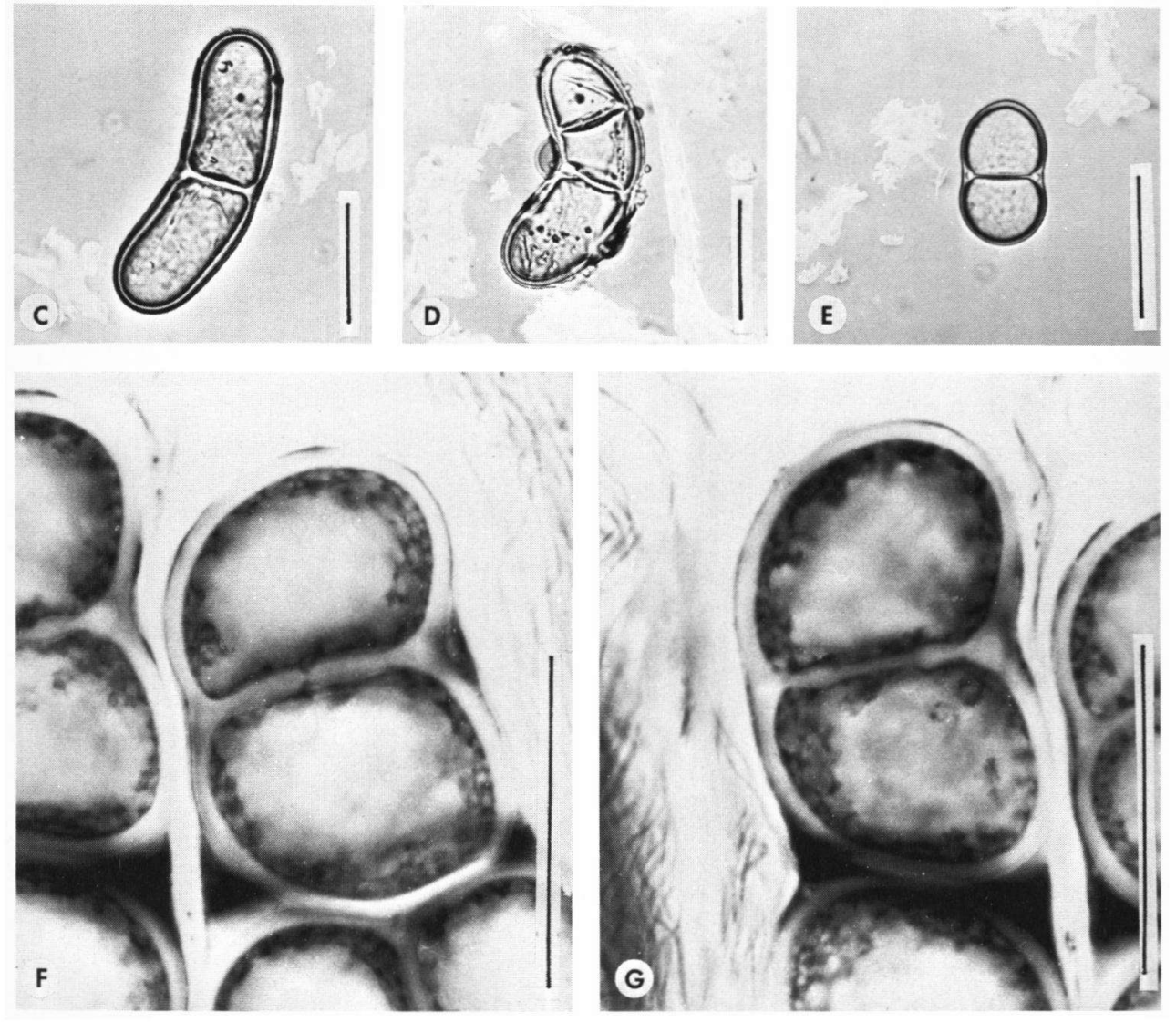

PLATE 19. Sulphurata-type spores. A. Megalospora sulphurata var. nigricans, short, small spores (Sipman 13088); B. Megalospora sulphurata var. sulphurata, elongate spore (Kjellberg 102); C. Megalospora sulphurata var. sulphurata, slightly decayed spore (Kjellberg 102); D. Megalospora sulphurata var. sulphurata, decaying, abnormal spore with additional septum (Kjellberg 102); E. Megalospora subtuberculosa, short, straight spore (Chamberlain s.n.); F. Megalospora sulphurata var. nigmicans, spore with narrow pore in the septum (Sipman 13088); G. same slide, spore with incompletely thickened septum. Rule $=40 \mathrm{\mu m}$. 
A

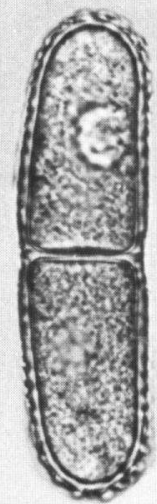

B

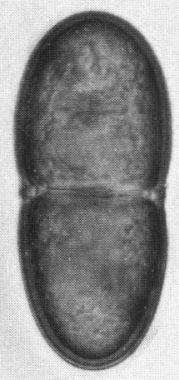

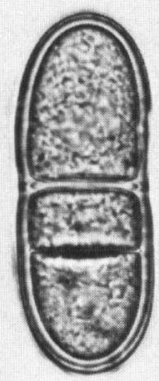

C

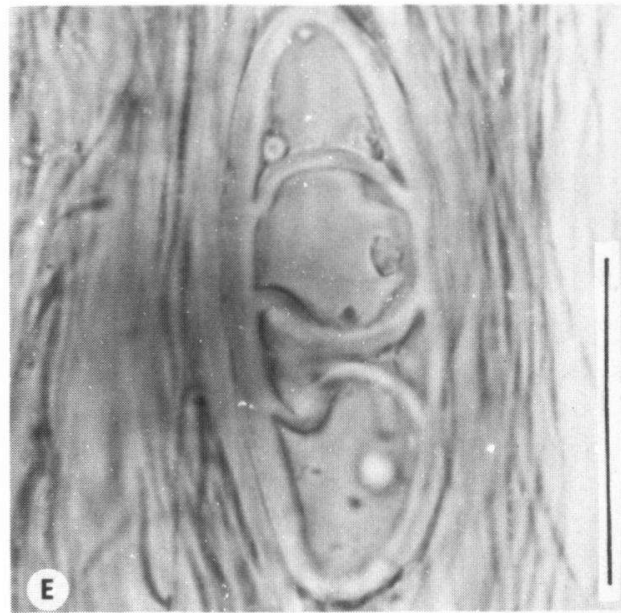

D

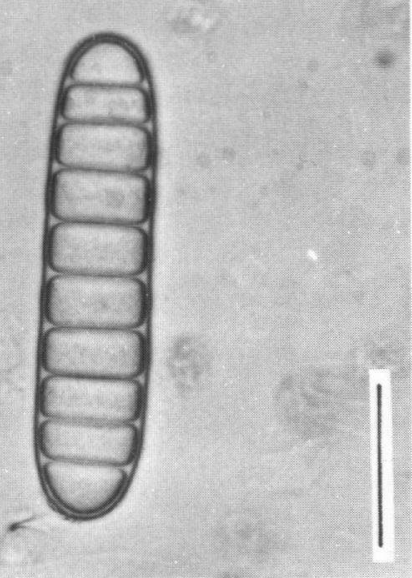

E
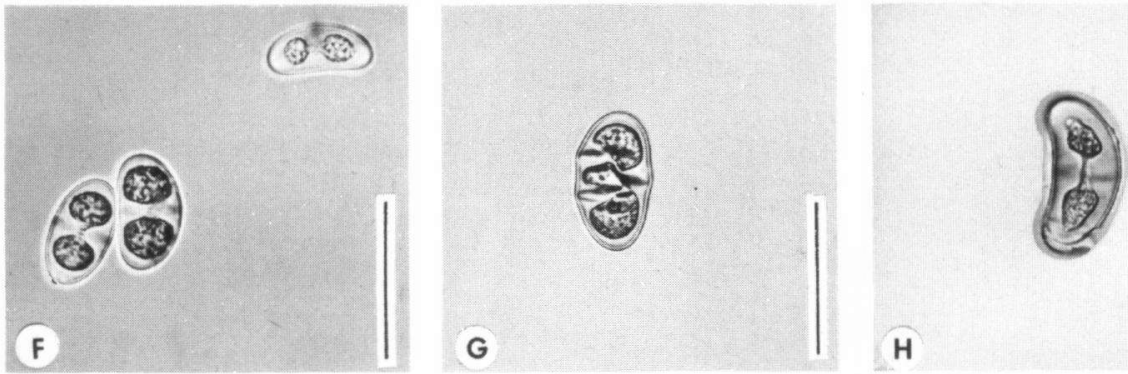

H

PLATE 20. Megalosporaceae, spores. A. Mcyalospora gompholoma ssp. gompholoma, spore with warted epispore (Zotov s.n.); B. Megalospora atrorubicans ssp. australis, spore with smooth epispore (Allan s.n.); C. Megalospora atrorubicans ssp. australis, abnormal spore with additional septum (Allan s.n.); D. Megaiospora tuberculosa, bacillar-pluriseptate spore (Sipman 12728); E. Megalospora coccodes ssp. niaricans, degenerate spore in ascus (Sipman 15708); F. Megaloblastenia marginiflexa var. marginiflexa, spores (Knight 123); G. Megaloblastenia marginiflexa var. marginiflexa, abnormal spore (Knight 123); H. Megaloblastenia flavidoatra, damaged spore showing firm consistency of outer layer of spore wall (Allan s.n.). Rule $=40 \mu \mathrm{m}$. 

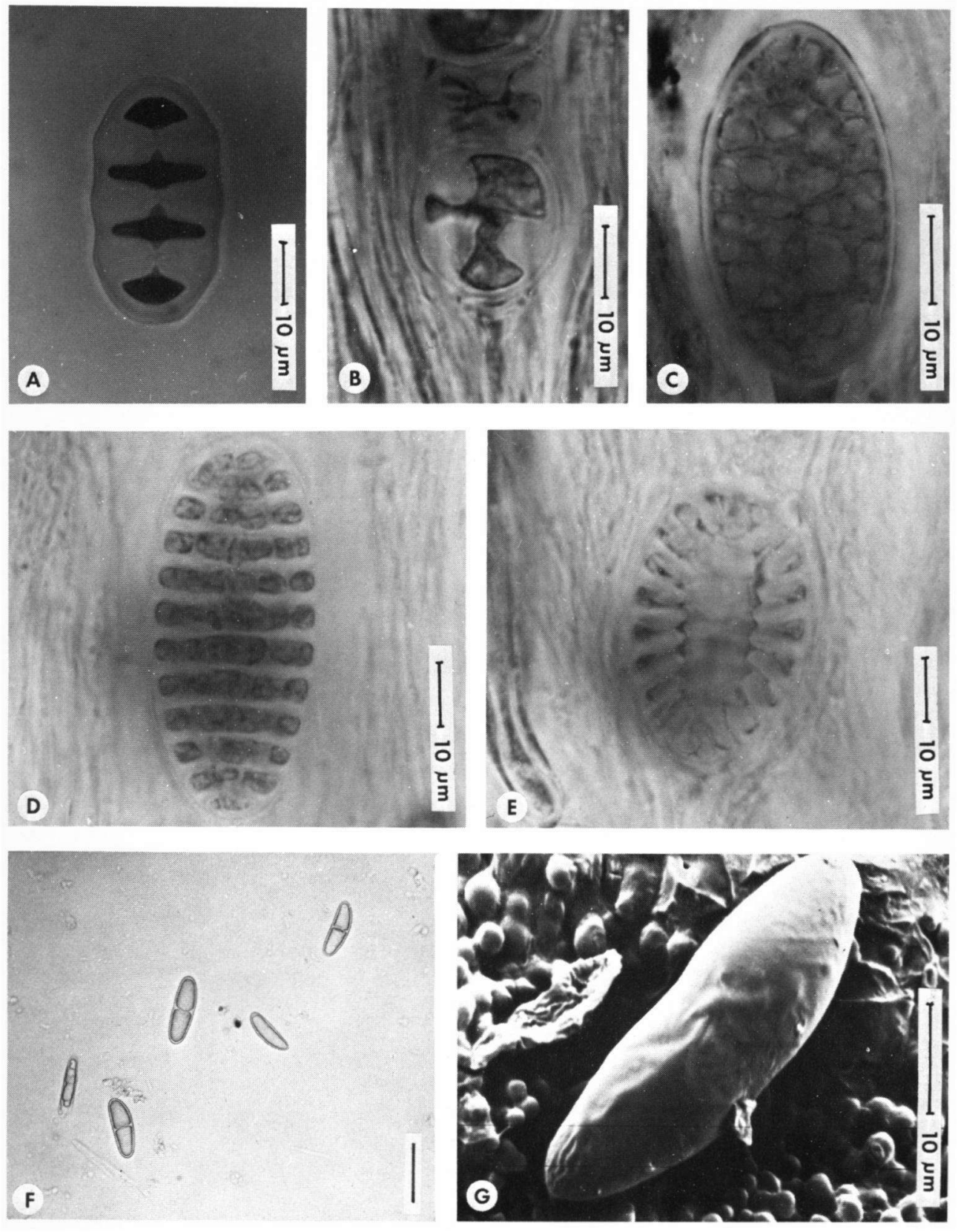

PLATE 21. Megalosporaceae and Catinaria versicolor, spores. A. Austroblastenia pauciseptata (Sipman 16784); B. Austroblastenia pauciseptata, abnormal spore (Sipman 16791); C. Megalospora Lopadioides, spore in ascus (Sipman 16133); D. Austroblastenia pupa, spore in ascus (Galloway s.n.); E. Austroblastenia pupa, degenerate spore in ascus (Galloway s.n.); F. Catinama versicolor, spores in various stages (Hale 44002); G. Catinamia versicolor, SEM microphotograph of spore showing smooth wall (Sipman 11025). Rule $=40 \mu \mathrm{m}$, unless otherwise indicated. 

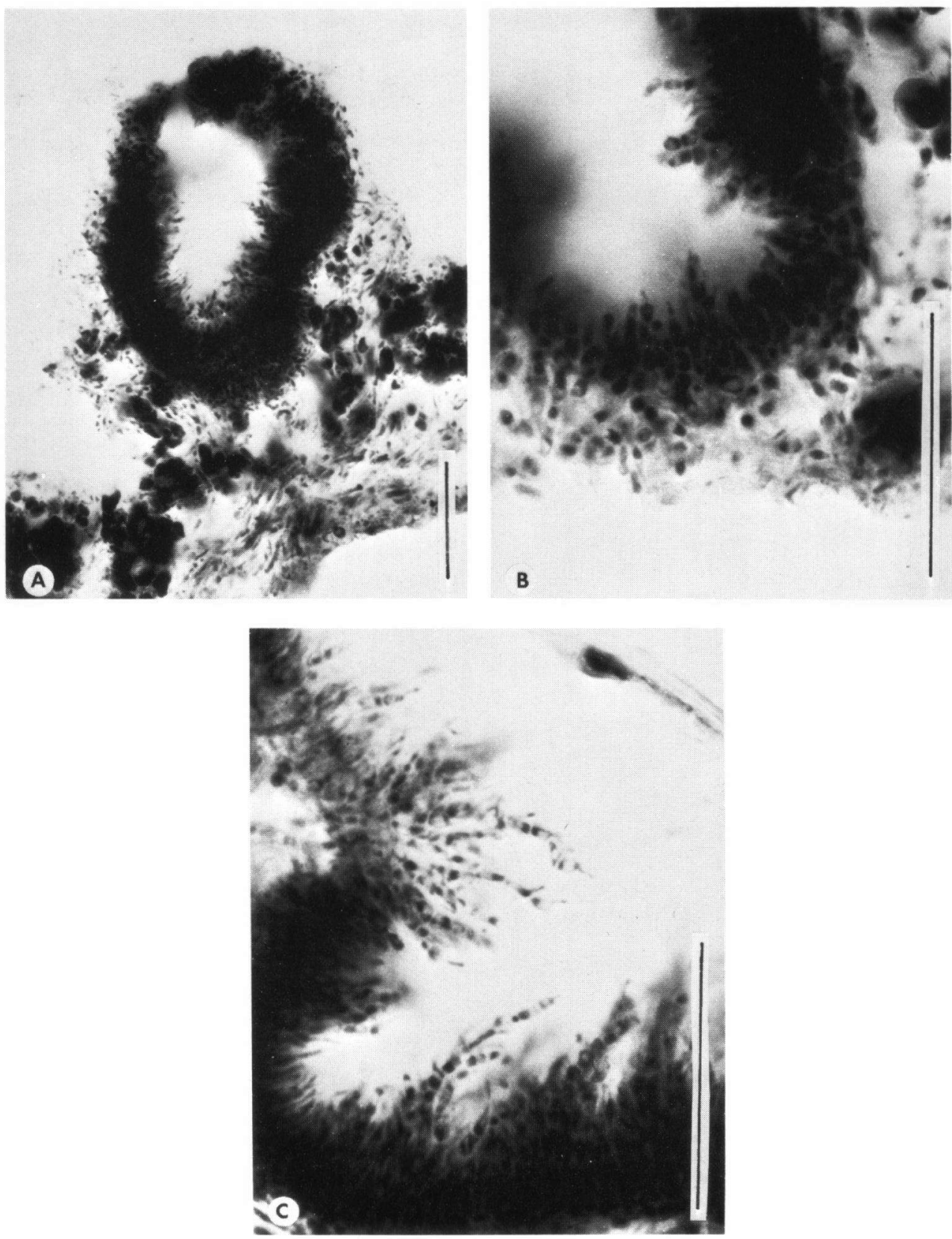

PLATE 22. Megalospora sulphurata, pycnidium. A. cross section (Sipman 12728); B.

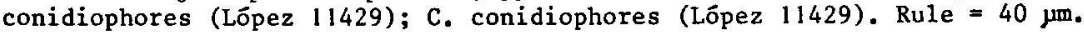



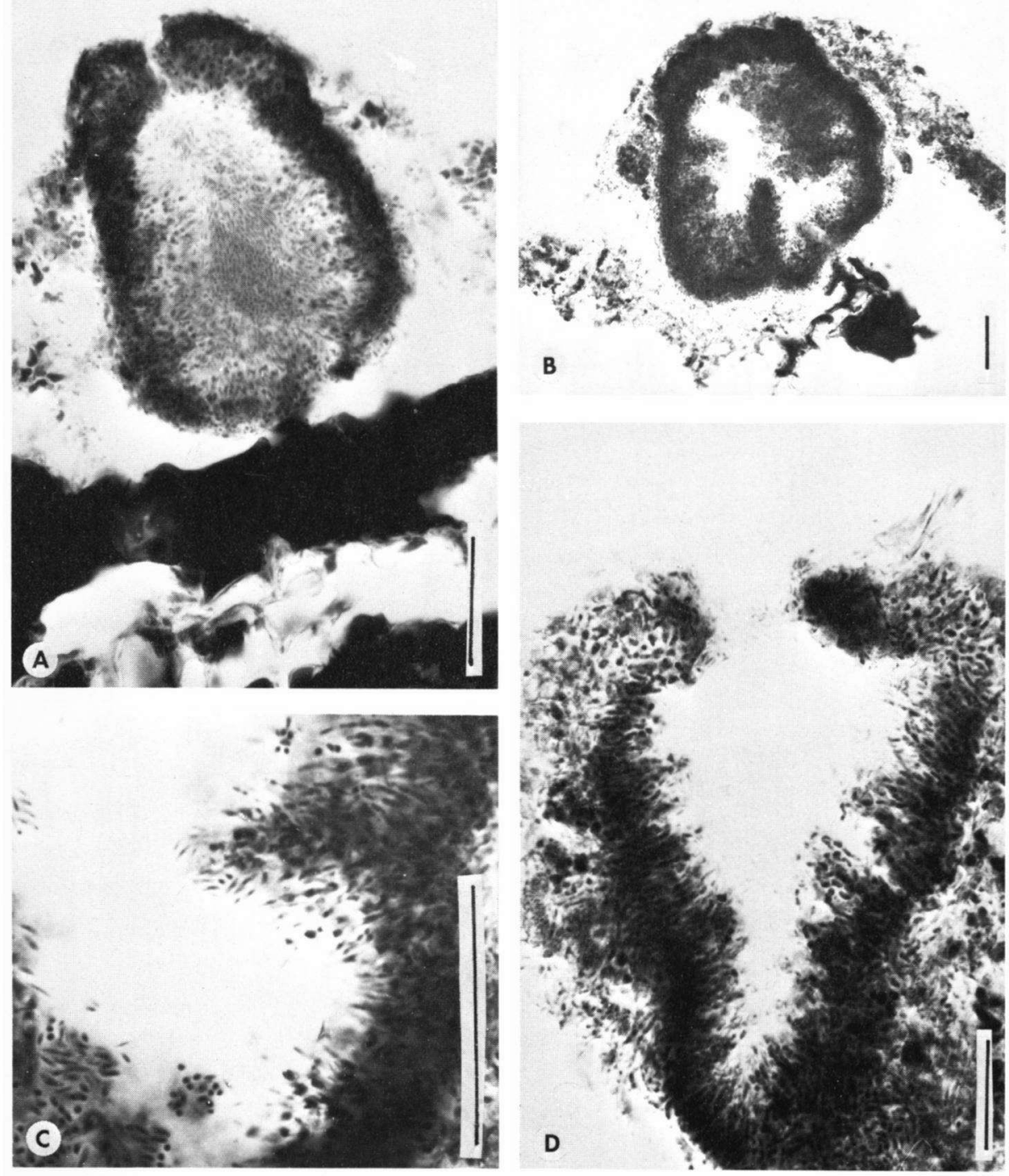

PLATE 23. Megalosporaceae, pycnidia. A. Megalospora gompholoma ssp. gompholoma, young pycnidium (H-Nyl. p.m. 4537); B. Megalospora gompholoma ssp. gompholoma, old pycnidium (H-Nyl. p.m. 4537); C. Megalospora gompholoma ssp. gompholoma, conidiophores (H-Nyl. p.m. 4537); D. Megaloblastenia marginiflexa var. marginiflexa, pycnidium (Tucker 20264). Rule $=40 \mathrm{\mu m}$. 

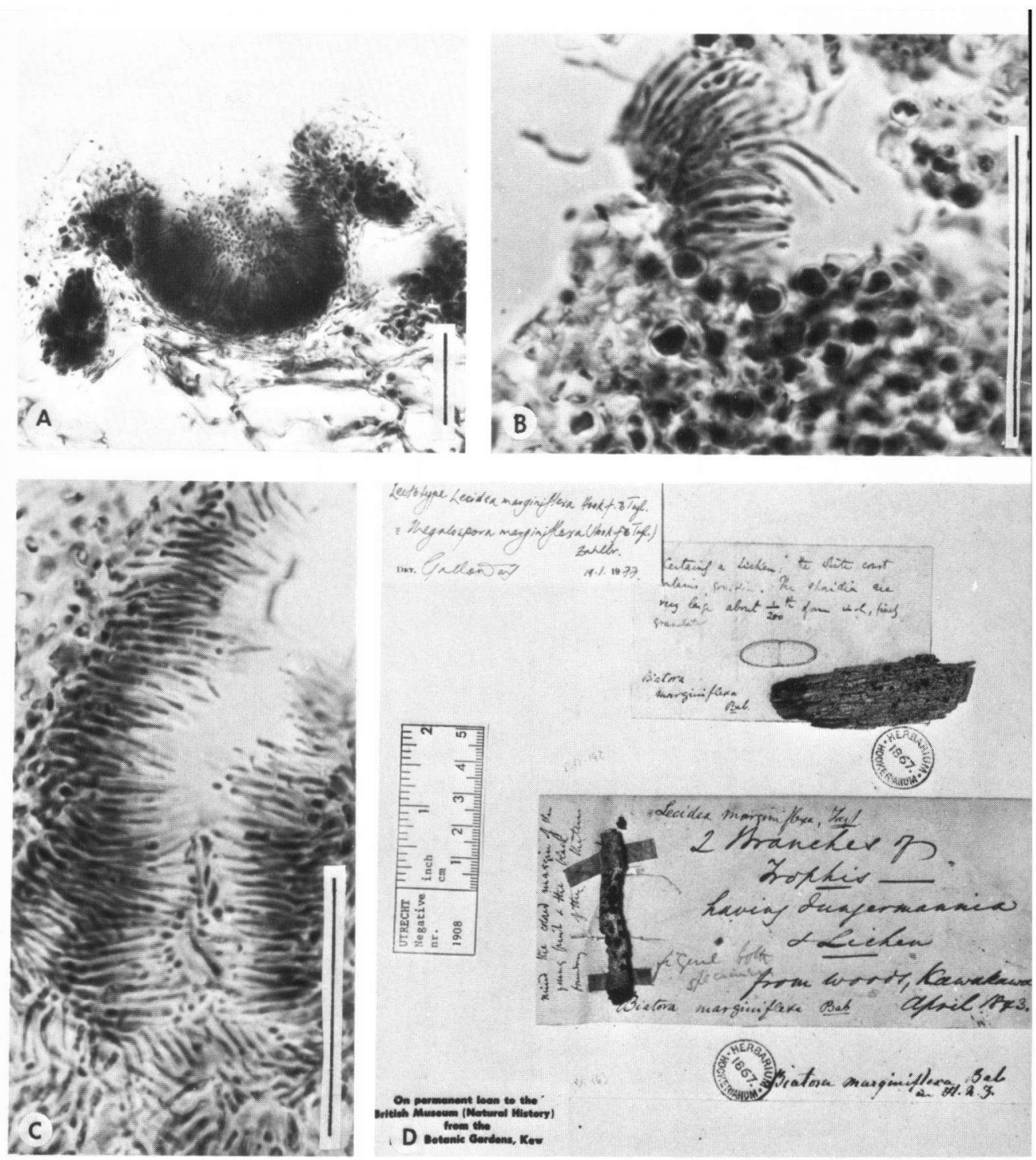

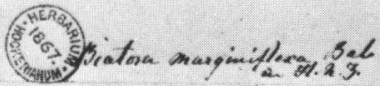

PLATE 24. Catinaria versicolor, pyenidium, and Megaloblastenia marginiflexa, type specimen. A. Catinaria versicolor, pycnidium (López 22801); B.Catinaria versicolor. conidiophores (López 9227); C. Catinaria versicolor, conidiophores (López 9227); D. part of original material of Lecidea marginiflexa, including the type (lower specimen). Rule $=40 \mathrm{~mm}$ unless otherwise indicated. 